\title{
A TELEPÜLÉS I ÖNKORMÁNYZATOK SZEREPE A KÖRNYEZETI POLITIKA ÉS JOG ALAKÍTÁSÁBAN
}

SZERKESZTETTE

FODOR LÁSZLÓ ÉS BÁNYAI ORSOLYA 
A települési önkormányzatok szerepe a környezeti politika és jog alakításában

Szerkesztette

Fodor László-Bányai Orsolya

A tanulmánykötet megjelenését a Nemzeti Kutatási, Fejlesztési és Innovációs Hivatal támogatása tette lehetővé, a K 115530 ny. sz. kutatási projekt keretében.

Lektorálta:

Kecskés Gábor, Szilágyi János Ede

C Barta Attila, Bándi Gyula, Bányai Orsolya, Fodor László, Fónai Mihály, Fórika László, Némedi Erika, Pénzes Ferenc, Pump Judit, 2017

(C) Debreceni Egyetemi Kiadó Debrecen University Press, beleértve az egyetemi hálózaton belüli elektronikus terjesztés jogát is

A borítókép forrása: http://www.pptbackgrounds.org/modern-city-ingreen-plants-backgrounds.html

DOI: 10.5484/fodor_banyai_telepulesi_onkormanyzatok ISBN 978-963-318-631-2 online változat: ISBN 978-963-318-632-9

Kiadta:

az 1795-ben alapított Magyar Könyvkiadók és Könyvterjesztők Egyesülésének a tagja

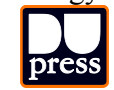

www.dupress.hu

Felelős kiadó: Karácsony Gyöngyi

A nyomdai munkálatokat

a Debreceni Egyetem sokszorosítóüzeme végezte 2017-ben 


\section{TARTALOMJEGYZÉK}

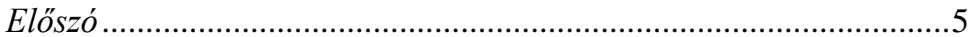

Bándi Gyula: Fenntarthatóság, reziliencia, önkormányzatok............7

1. Fenntarthatóság, fenntartható fejlődés,

önkormányzati kitekintés .7

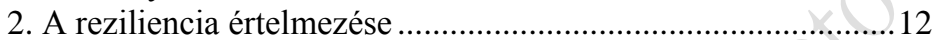

3. Reziliencia és kormányzás, reziliencia és önkormányzatok ....15

4. A reziliencia és annak jogi vonatkozásai, intézményesülése ...19

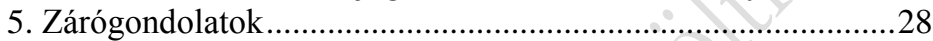

Pump Judit: Helyi környezetpolitika - Göröngyök az úton...............29

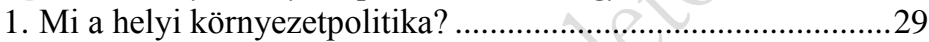

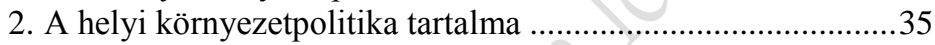

3. A helyi környezetpolitika jogi és igazgatási rendszere .............45

4. A helyi környezetpolitika létrehozásának és végre-

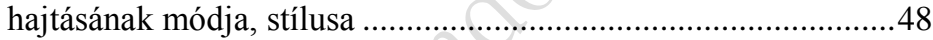

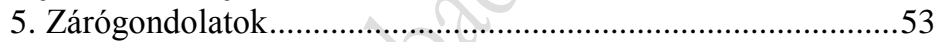

Fodor László: A környezetvédelmi szabályozás helyi szintje ............55

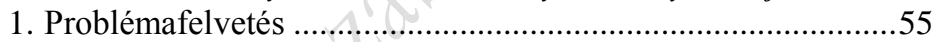

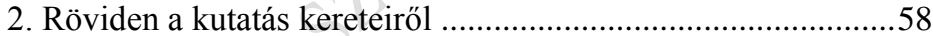

3. A környezet védelmét szolgáló helyi rendeletek köre ...............60

4. Néhány vitatható megoldás a helyi rendeletekben.....................64

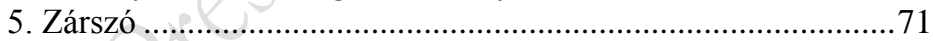

Fónai Mihály - Pénzes Ferenc: Önkormányzatok és helyi környezeti politika - egy empirikus kutatás eredményei ........................73

1. Az önkormányzati rendszer változásai ....................................73

2. A kutatás során alkalmazott módszerek..................................78

3. A kérdőíves kutatás mintája és a kutatás dimenziói..................79

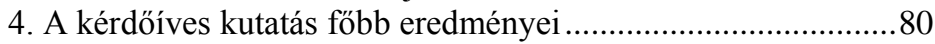

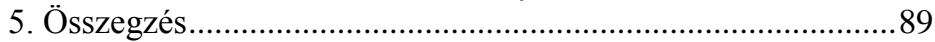

Bányai Orsolya: Helyi stratégiák és környezetvédelem ...................91

1. Környezetvédelmi stratégiák és szakirodalmi köve-

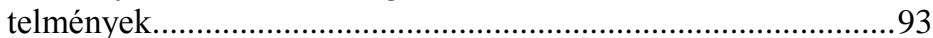

2. Települési környezetvédelmi programok................................95

3. A fenntartható fejlödési stratégiák ...........................................99 
4. Települési önkormányzatok energiafelhasználással kapcsolatos stratégiaalkotása

5. Összegzés és következtetés.

Barta Attila: Önkormányzati társulások a helyi környezetvédelmi feladatok ellátásában

1. A társulások mibenléte, típusai

2. A hazai társulási rendszer jellemzői. Számok, példák

3. Határtalanul? - nemzetközi vonatkozások

4. Záró gondolatok

Némedi Erika: Partnerségi-e az egyeztetés? - A településrendezési eszközök nyilvánosságának kérdései egy esettanulmányon keresztül

1. A közösségi cselekvést kiváltó esemény

2. A lakossági vélemény hatósági eljárásokba történő becsatornázásának gyakorlata.

3. Egy kezdeményezés sikere a partneri kapcsolat fokmérője? .132

4. A Helyi Építési Szabályzat egyeztetése

5. A társadalmi részvétel helyi szabályozásának hiánya.............134

6. A környezeti értékelés eljárásának kiüresítése 138

7. Válasz a kérdésre: partnerségi-e az egyeztetés?

Fórika László: Az ivóvizhez való jog biztositása az ombudsmani vizsgálatok tükrében.

1. Az ivóvízhez való jog, mint alapvető jog

2. Az ivóvízhez való hozzáférés

3. Az ivóvízzel kapcsolatos beadványok típusai...

4. Az ózdi kútelzárás ügye, 2013

5. Összegzés

6. Kitekintés

Függelék - A K115530 sz. kutatási projekt online kérdöive 


\section{ELŐSZÓ}

A települési önkormányzatoknak a környezeti fenntarthatóság megvalósításában játszott szerepét a deklarációk, stratégiák szintjén minden dokumentum elismeri s nagyra értékeli. A térhasználatok közötti konfliktusok megelözésében a településrendezésnek, a klímaváltozáshoz való alkalmazkodásban a helyi építési szabályoknak és a mobilitás szervezésének, a helyi közösség békéjének megőrzésében a zajvédelmi szabályoknak és a közösségi együttélés szabályozásának a szerepe hazánkban is közismert. Az is nyilvánvaló, hogy egy település életében a környezetvédelem megjelenik a közszolgáltatások szervezésében, a fejlesztési stratégiák megfogalmazásában, a civil szerveződésekkel való kapcsolatban, s ezer más formában. Ez a kötet nem törekszik a címében kifejezett összefüggések teljes körü bemutatására, csupán felvillant néhányat a környezetvédelmi feladatok ellátásával kapcsolatos elvi, szabályozási, szakpolitikai, alapjogi kérdések közül.

A szerzők egy része a Debreceni Egyetem munkatársa, akik egy kifejezetten a témakörrel foglalkozó kutatócsoport tagjai. Az ő írásaik ennek megfelelően részeredményeknek tekinthetők. Mellettük - nagy örömünkre, kérésünket elfogadva - más neves elméleti és gyakorlati szakértők is elmondják véleményüket, javaslataikat egy-egy problémáról. Együttmüködésükért külön köszönettel tartozunk.

A kötet hátterében egy 2016. november 18-án, a Debreceni Egyetem jogi karán tartott, tudományos konferencia áll. Az ott elhangzott előadásokat követően - további résztvevők bevonásával - szakmai vitára került sor. A szerzők részben erre figyelemmel, részben számos új iránnyal, kutatási eredménnyel egészítették ki mondandójukat, s így születtek meg az egyes tanulmányok, a könyv fejezetei. Ennek megfelelöen bízunk abban, hogy kötetünk széles körben lesz hasznosítható.

Debrecen, 2017 tavaszán 


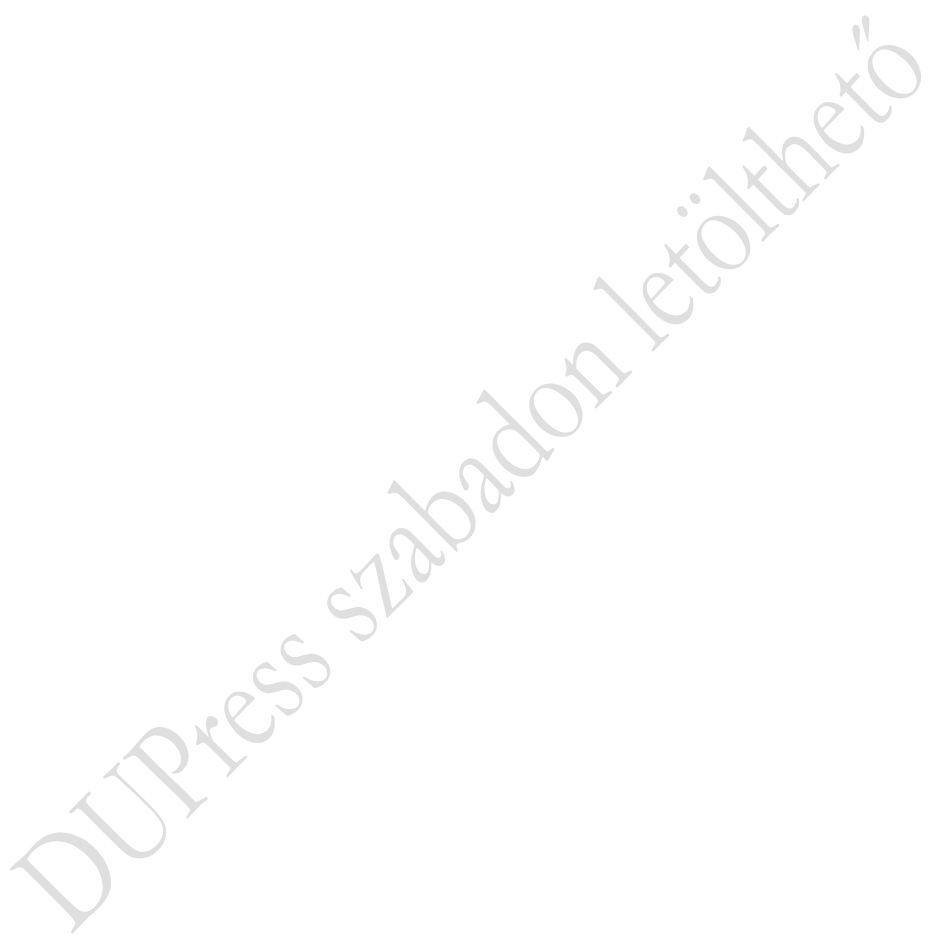




\title{
FENNTARTHATÓSÁG, REZILIENCIA, ÖNKORMÁNYZATOK
}

\author{
Bándi Gyula*
}

\section{Fenntarthatóság, fenntartható fejlődés, önkormányzati kitekintés}

A jövőt kutató munkák sorában a Római Klub közismert jelentései közül talán a legnagyobb hatású volt a Növekedés határai címmel 1972-ben megjelent, ${ }^{1}$ majd 30 évvel később megismételt ${ }^{2}$ jelentés, amelynek beszédes címe a mai értelemben vett fenntartható fejlődés elöfutáraként is értékelhető. Most azonban nem ennek a két kötetnek valamely részét emelem ki jelen írás kiindulási pontjaként, hanem egy sokkalta újabb nyilatkozatot a jelentések, kötetek ma is aktív szerzőjétől, Dennis Meadowstól származtatva: „Sokkal inkább érdekel engem a 'reziliencia' fogalma. Ez a koncepció azt mutatja meg, hogy egy vállalat, város vagy ország miként szervezödik oly módon, hogy legyen képes müködni akkor is, ha súlyos válságok érik. Azok a politikák, amelyek a rezilienciát fejlesztik, fenntarthatóbbá tehetik a rendszert." ${ }^{3}$ Mindezt egy interjúban nyilatkozta Meadows, amit azzal kezdett, hogy a fenntartható fejlődés fogalmát olyan oximoronnak minősítette, amelynek jelentéstartalma értelmetlen. Ehelyett ő nagyobb figyelmet fordítana a rezilienciára. Ezt a fogalmat alkalmazza a pszichológia, ${ }^{4}$ az idegen szavak

* Prof. Dr. Bándi Gyula, DSc, tanszékvezető egyetemi tanár, PPKE JÁK, Környezetjogi és Versenyjogi Tanszék.

1 Meadows, Donella H.-Meadows, Dennis L.-Randers, Jorgen-Behrens III, William W.: The Limits to Growth. A report for The club of rome's project on The predicament of mankind. Universe Books, New York, 1972.

${ }_{2}$ Meadows, Donella H.-RANDERs, Jorgen-Meadows, Dennis L.: A növekedés határai harminc év múltán. Kossuth Kiadó, Budapest, 2005.

${ }^{3} \mathrm{https} / / / \mathrm{www}$. siemens.com/content/dam/internet/siemens-com/innovation/pictures-ofthe-future/pof-archive/pof-spring-2010.pdf, 57. (2016. december 20.)

${ }^{4}$ A Wikipédia szerint: „A reziliencia általános értelemben rugalmas ellenállási képesség, azaz valamely rendszernek - legyen az egy egyén, egy szervezet, egy ökoszisztéma vagy éppen egy anyagfajta - azon reaktív képessége, hogy eröteljes, meg-megújuló, vagy akár sokkszerü külsö hatásokhoz sikeresen adaptálódjék." 
gyüjteményében egyszerüen, mint „rugalmas ellenállási képesség” jelenik meg, ${ }^{5}$ és a legtöbb nézet szerint a fogalom a hatvanas évek végén - a hetvenes évek elején jelent meg az ökológia fogalomtárában. ${ }^{6}$ Indokolt tehát, ha foglalkozunk kissé ezzel a gondolattal, ennek értelmezésével, következtetéseivel is.

Elöbb azonban természetesen mindenképpen figyelmet kell forditani a fenntartható fejlödés alapjaira, még akkor is, ha azok mindenki számára ismertek. Hiszen ha továbbra is ezt tekintjük kiindulási alapnak, akkor szükségképpen - legalább vázlatosan foglalkozni kell a kérdéssel, ${ }^{7}$ körvonalazva tartalmát.

1987-ben jelent meg az ENSZ Környezet és Fejlödés Világbizottságának azon meghatározó jelentése, amelyik a fenntartható fejlödést tekintette központi kérdésének, és amelyik elindította ezen eszme rohamos elterjedését. A bizottság szerint: „, $A$ fenntartható fejlödés olyan fejlödés, amely kielégiti a jelen szükségleteit, anélkül, hogy veszélyeztetné a jövö nemzedékek esélyét arra, hogy ök is kielégithessék szükségleteiket." Nem tér el ettől a Világ Tudományos Akadémiáinak Nyilatkozata sem (Tokió, 2000): „a fenntarthatóság az emberiség jelen szükségleteinek kielégitése, a környezet és természeti eröforrások jövő generációk számára történö megörzésével egyidejüleg." A Nemzeti Fenntartható Fejlödési Stratégia ${ }^{8}$ (NFFS) 3.1. pontja szerint pedig: „A fenntarthatóság tehát az emberiség folytonos megújulását, a jövöért érzett felelösség cselekvésekben testet öltö tudatos érvényesitését, a változó környezethez való alkalmazkodását jelenti, a természeti eröforrások mennyiségi és minöségi megörzése érdekében. A fejlödés pedig az ebben az alkalmazkodásban bekövetkezö javulást jelenti." Az NFFS fogalmazásából kiemelendő, hogy megjelenik a változó környezethez való alkalmazkodás igénye, amely - amint alább látjuk majd - nélkülözhetetlen eleme a reziliens gondolkodásnak. Nem feledkezhetünk meg e téren arról sem, hogy az NFFS az

https://hu.wikipedia.org/wiki/Reziliencia_(pszichol\%C3\%B3gia) (2016. december 20.).

${ }_{6}^{5}$ http://idegen-szavak.hu/reziliencia (2016. december 20.).

6 SZOKOLSZKY Ágnes-V. KOMLÓSI Annamária: A „reziliencia-gondolkodás” felemelkedése - ökológiai és pszichológiai megközelítések. Alkalmazott Pszichológia 2015/15,11-26.

7 A következőkben hivatkozott fogalmak megtalálhatóak a http://www.ff3.hu/fejlodes.html url címen (2016. december 20.).

${ }^{8}$ 18/2013. (III. 28.) OGY határozat. 
„ösforráshoz” képest 26 évvel fiatalabb, amikor a reziliencia ugyancsak széles körben alkalmazott volt, tehát nem is kerülhette meg, hogy ezt valamilyen formában ne tartalmazta volna.

A fenntartható fejlődés gondolata, értelmezése nem sokat változott az elmúlt három évtizedben, ellenben annál többet változtak a kapcsolódó megoldási variációk, receptek. Különösen nehéz a fenntartható fejlödés jogi értelmezése. Minderre nézve máshol ${ }^{9}$ már részletesen szóltam, - pl. felidézve, hogy Fitzmaurice szerint a fenntartható fejlödés bizonytalan, ${ }^{10}$ míg Lowe megjegyzi, hogy a fenntartható fejlődést, mint jogi kategóriát zavar és homály fedi ${ }^{11}$ - ezeket nem kívánom megismételni. Annyit emelnék ki még ezen értelmezési kísérletből, hogy miközben a mai napig nem tudjuk pontos és megfogható tartalommal kitölteni a fenntartható fejlődés lényegét, azonközben mindennek keretei és tartalma is folyamatosan különböző értelmezési megközelítést kapnak - ilyen impulzus véleményem szerint a zöld gazdaság ${ }^{12}$ koncepciója, vagy a legújabb uniós stratégia a körforgásos gazdaság ${ }^{13}$ (amit eleinte körkörös gazdaságnak neveztek) megvalósítása felé.

Annak az elsődleges oka, hogy a fenntartható fejlödés nem képes áttörést, érdemi változást elérni, abban keresendö, hogy a bármilyen magasztos általános célok megvalósítása nyilvánvalóan nem lehetséges a jelenlegi döntéshozatali, kormányzási, gazdasági keretek között. Egyszerü szavakkal írja ezt körül Ferenc pápa: „Sajnos a környezeti válság konkrét megoldásainak keresésére irányuló sok

9 BÁNDI Gyula: A fenntarthatóságtól a körkörös gazdaság felé: EU stratégiák alakulása és ennek jogi következményei. FontesIuris 2016/2, 13-21.

${ }^{10}$ A fenntarható fejlődés, mint az elővigyázatosság elve is, a nemzetközi jog alapvető koncepciói közé tartozik, amelynek tényleges természetét misztifikálta és felfoghatatlanná tette a számos, talán túlzottan is számos alkalmazási terület. Lásd FITZMAURICE, Malgosia: Contemporary Issues in International Environmental Law. Edward Elgar Publishing, Cheltenham, 2009, 67.

${ }^{11}$ LOWE, Vaughan: Sustainable Development and Unsustainable Practices. In: BoYLE, Alan E.-FreESTONE, David (eds.): International Law and Sustainable DevelopmentPast Achievements and Future Challenges. Oxford University Press, Oxford,1999, 23.

12 Lásd például A Guidebook to the Green Economy. UNDESA, 2012, https://sustainabledevelopment.un.org/content/documents/GE\%20Guidebook.pdf (2016. december 20.).

${ }^{13}$ A Bizottság közleménye az Európai Parlamentnek, a Tanácsnak, az Európai Gazdasági és Szociális Bizottságnak és a Régiók Bizottságának: Az anyagkörforgás megvalósítása - a körforgásos gazdaságra vonatkozó uniós cselekvési terv, $\operatorname{COM}(2015) 614$ végleges. 
törekvés nemcsak a hatalmasok elutasitása miatt szokott kudarcot vallani, hanem a többiek érdektelensége miatt is." ${ }^{14}$ Majd később a hivatkozott politikai rend gyengeségeit ostorozza: „Annak a politikai magatartásnak a drámája, amely azonnali eredményekre törekszik, és amelyet a fogyasztói szemléletü rétegek is fenntartanak, kiprovokálja a rövid távú növekedés szükségességét. Választási érdekeiknek megfelelöen a kormányok nem egykönnyen merészelik bosszantani az embereket olyan intézkedésekkel, amelyek hatással lehetnek a fogyasztás mértékére vagy veszélyeztetnék a külföldi befektetéseket. A rövidlátó hatalomszerzés igénye megakadályozza a széles látószögü környezetvédelmi teendök beillesztését a kormányok nyilvános programjába." ${ }^{15}$ Tehát hiába is ismerjük fel mindazt a számos lehetőséget, utat, amely elvezethet a fenntarthatóság felé, azokon jobbára nem járunk, mert alapvető rendszerváltozást jelentene. Ez igaz az egyénekre, csoportokra, gazdaságra, államra, nemzetközi közösségre egyaránt. A hosszú távú gondolkodás megvalósitása rövidtávú áldozatokat vár el a döntéshozók minden szintjétöl.

$\mathrm{Az}$ elmondottak alapvetöen igazak az önkormányzatokra is, amelyek nem vonhatják ki magukat a fenntartható fejlődés - vagy bármiként is nevezzük - megvalósításának követelménye alól. A döntések, beruházások, akármilyen más lépések sora egymásra épül, és együttesen jelenik meg, tehát minden szereplő fontos, az egyéni fogyasztótól a globális szereplökig. Ezen belül a települési önkormányzatok felelössége kiemelkedö, hiszen a település mindennapi működtetése ezer szálon kapcsolódik a fenntarthatósághoz. A hulladékkezelés, a tömegközlekedés, a zöldfelületek kezelése, a közintézmények ellátása, fütése mellett talán még kiemelkedőbb jelentőségü a település területének okszerü és ésszerü felhasználása, a felhasználás ellenőrzése. Mindezek egyenként és összességében olyan elemek, amelyek nélkülözhetetlen hozzájárulást adnak az egész folyamathoz. E téren egyik közismert szereplő a helyi önkormányzatok fenntarthatóságának erősítését célzó nemzetközi szervezet, az ICLEI, ${ }^{16}$ aminek itt csupán a

\footnotetext{
${ }^{14}$ Laudato $S i$ - FERENC pápa „Áldott légy” kezdetű enciklikája. Szent István Társulat, Budapest, 2015, 14. pont.

${ }^{15}$ FERENC pápa: i.m., 178. pont.

${ }^{16} \mathrm{http} / / /$ www.iclei-europe.org/home/(2016. december 20.).
} 
vonatkozó önkormányzati szerepeket összegző egyik (2011-ből származó) nyilatkozatára ${ }^{17}$ hivatkozhatunk, mint lehetséges forrásra.

Az önkormányzatok nélkül tehát a fenntarthatóság megvalósitása, az ennek érdekében megvalósuló fejlödés nem lehet teljes. Márpedig a fenntartható fejlődés felé vezető utak egyike éppen a reziliencia által meghatározottak szerinti döntéshozatal és struktúra-változás, sőt ebben az önkormányzatok részesedése minden másnál alapvetőbb terület, hiszen a reziliencia alkalmazása feltételezi a helyi, önkormányzati szint eddiginél sokkal nagyobb szerepét, részvételét. A Riói Nyilatkozat ${ }^{18}$ közvetlenül csupán 22. elvében utal a helyi közösségek szerepére, de nem is várható el több ennél, az általánosság ezen szintjén.

Ennél némileg többet tartalmaz az ún. $\mathrm{SDG}^{19}$ az ENSZ fenntartható fejlődési céljainak gyüjteménye, amit 2015-ben fogadtak el. A vonatkozó Nyilatkozat 34. pontjában jelzi: „Elismerjük, hogy a fenntartható településfejlesztés és gazdálkodás népeink életminösége szempontjából alapvetö fontosságú. Együttmüködünk az önkormányzatokkal és a helyi közösségekkel városaink és településeink tervezése és megújitása terén, hogy erösitsük a közösségi összetartást és a személyes biztonságot, és ösztönözzük az innovációt és a foglalkoztatást." Később az ún. Fenntartható fejlesztési célok között, a 11. célkitüzés címe szerint: „A városokat és emberi településeket befogadóvá, biztonságossá, alkalmazkodóvá, állóképessé és fenntarthatóvá tesszük." Az természetes ezen dokumentumok esetében, hogy központi kérdésük a nemzetközi együttmüködés és a nemzetközi erőfeszítések megfelelő mederbe terelése, és kevésbé, inkább érintőlegesen a helyi lehetőségek részletezése - több nem is várható tölük.

17 ICLEI European Convention Declaration, Brussels, 13 September 2011 http://convention2011.iclei-

europe.org/fileadmin/templates/files/Press_corner/Press_releases/Microsoft_Word__ICLEI_European_Convention_2011_Draft_Declaration_final.pdf (2016. december 20.).

${ }^{18}$ http://www.nfft.hu/dynamic/Rio_Decl_m.pdf (2016. december 20.).

${ }^{19}$ Világunk átalakítása: a fenntartható fejlődés 2030-ig megvalósítandó programja. Az Egyesült Nemzetek Közgyülése által 2015. szeptember 25-én elfogadott, 70/1. sz. határozat, magyar nyelven

elérhetö: http://jak.ppke.hu/uploads/collection/545/file/Vilagunk_atalakitasa.pdf (2016. december 20.). 


\section{A reziliencia értelmezése}

Az önkormányzati szerepek ilyetén felvázolását követően $a$ reziliencia értelmezése a következö feladat, majd természetesen a két kérdéskör megfelelő összekapcsolása. ${ }^{20}$ Kezdjük talán hazai szerzőkkel, akik átvezetnek minket a fenntartható fejlődés kérdésétől ahhoz, amit később rezilienciaként azonosíthatunk. Elsősorban $a$ fenntarthatóság felé vezetö utat kövezzük ki: „...a fenntartható fejlödést akkor szolgáljuk, ha csökkentjük a gazdaság szivó hatását, és egységnyi (növekvő mértékben megújuló) eröforrással minél több jóléti szolgáltatást nyújtó terméket gyártunk. A fenntartható fejlödés felé való átmenetet segitjük, ha a gazdaság nyitott láncait zárjuk és egyre több visszacsatoló hurkot épitünk be termelésünkbe, fogyasztásunkba, csökkentve ezzel a magasabb entrópia, a rendezetlenség állapotába való kerülést. Fontos követelmény, hogy a fenntarthatóságot szolgáló lépésünket a folyamat minél korábbi fázisában megtegyük. (Hatásosabban szolgálja a fenntarthatóságot pl. egy megújuló üzemanyagot felhasználó motor, mint egy katalizátorral felszerelt autó.) A fenntartható fejlödés megvalósulása hosszú távú, globális feladat. A megvalósitáshoz azonban szükséges a program szintjeinek meghatározása és a feladatok megfogalmazása a kisközösségek, a családok, söt az egyes emberek szintjéig." 21

A fenntartható fejlödés ezek szerint minden lehetséges szinten értelmezendö, és minden lehetséges szinten megvalósitandó feladat. Ennek maradéktalan megvalósulásához azonban nagy szükség lenne az alkalmazkodás képességére: „, A rugalmas, alkalmazkodni képes és ezért fenntartható, társadalmi-ökológiai rendszert a következők jellemzik:

- a diverzitás fenntartása és megőrzésének támogatása (biológiai, tájképi, gazdasági és társadalmi értelemben is),

- az ökológiai sokféleség ember általi "kontrolljának" korlátozása,

\footnotetext{
${ }^{20}$ A reziliencia értelmezésének alakulása iránt érdeklődőknek javaslom: HUMBY, Tracy-Lynn: Law and Resilience. Mapping the Literature in Seattle Journal of Environmental Law, 2014/4.

${ }^{21}$ SzLÁvIK János: Fenntartható fejlődés vagy növekedés? In: Dombi Ákos (szerk.) Gazdasági növekedés Magyarországon. Múegyetemi Kiadó, Budapest, 200, 107-117.
} 
- $\quad$ a modularitás tisztelete (a csatlakozó rendszerek jobban viselik a sokkhatást),

- a tanulás, a társadalmi hálózatok és a helyileg kifejlesztett szabályok fontosságának felismerése és hangsúlyozása. ${ }^{22}$

Eljutottunk a rugalmasság, sokféleség, alkalmazkodóképesség, tehát a változó körülmények felismerése és az azokhoz való igazodás területére, mint a fenntartható fejlődés megvalósulásához vezető utak többségét összesítő megoldási módhoz. Ha ennek elméleti alapjait szeretnénk bemutatni, számos forrásra támaszkodhatunk és támaszkodunk is, hiszen a reziliencia elméletét nem kívánom újraírni. Közöttük is a legjobban elismert a Nobel-díjas Elinor Olstrom, aki szerint ${ }^{23}$, A reziliencia, amely hasonló koncepció, mint az eröteljesség (robustness), az ökológia által kifejlesztett gondolat (Holling 1973), és arra szolgál, hogy mérje azokat a változásokat vagy zavaró hatásokat, amelyek szükségesek ahhoz, hogy átalakitsa az adott rendszert az egyik egymást erösitö folyamatból és rendszerböl egy másfajta rendszerbe és folyamatba... A reziliencia elméletének legújabb folyamatai hangsúlyozzák az adaptivitás képességet, és a változás köreit, amelyek számos szinten keresztül érvényesülnek (Gunderson and Holling 2002).

Minden ilyen rendszer három kérdésre kell figyeljen:

1. az együttmüködés és a közös cselekvés képessége a társadalmi rendszerekben fenntartandó,

2. az ökológiai rendszerek dinamikusak, amint azok a játékszabályok is, amelyeket a rendszerek szereplöi egymással szemben alkalmaznak, és

3. az ökológiai rendszerek elfoglalhatnak több stabil állapotot és gyorsan mozognak ezek között."

Tovább haladva az értelmezések terén újabb adalékot kapunk, közelebb kerülve a kérdés lényegéhez: „Reziliencia - A rendszer egészének és részeinek azon képessége, amellyel a veszélyeztetö

\footnotetext{
${ }^{22}$ KEREKES Sándor: Fenntarthatóság és társadalmi felelősség - A globalizálódó világ megoldatlan problémái. Magyar Bioetikai Szemle 2011/1, 10.

23 ANDERIES, John M.-JANSSEN, Marco A.-OSTROM, Elinor: A Framework to Analyze the Robustness of Social-ecological Systems from an Institutional $\begin{array}{lllll}\text { Perspective. Ecology and Society 2004/9. } & 18 .\end{array}$ http://www.ecologyandsociety.org/vol9/iss1/art18 (2016. december 20.).
} 
jelenségek hatásait elöre látja, elnyeli, azokhoz alkalmazkodik és helyreállitja magát, időben és hatékonyan, miközben megörzi, helyreállitja vagy javitja saját alaprendszerét és lényegi funkcióit." 24 Ugyanezen szerzők külön foglalkoznak a társadalmi vonatkozásokkal is: „A társadalmi-ökológiai rendszerekben (amit úgy vizsgálunk, mint a különbözö interaktív cselekvéseket az ember és a számára alapul szolgáló ökoszisztéma között) a reziliencia három tulajdonságot jelent: a változásnak azt a mennyiségét, amire a rendszer képes miközben fenntartja struktúráját és funkcióit; az újjászervezödés képességét; és azt, hogy milyen mértékben képes tanulási és adaptálási képességeket kialakitani. ",25

Kirajzolódni látszik immár a reziliencia (maradunk ennél a kifejezésnél, nem lévén alkalmas magyar szó, amely ugyanezt jelentené, bár a következő idézet tanulmánykötetének címe egy ismertebb fogalomra, az adaptációra is utal, ami azonban mégsem elégséges a tartalom megfelelö megjelenítésére) tartalma, értelme. Hazai forrásunk ${ }^{26}$ szerint: „Valamely társadalmi, gazdasági rendszer müködését tekintve azonban e fogalom tartalma: az elörelátás képessége, az, hogy integrált terveket, forgatókönyveket tud késziteni a természeti környezet és a társadalom (civilizáció) együtt müködésére, kölcsönhatásai elemzésére, (és igy) veszélyei minimalizálására, várható következményei elönyösebbé tételére. Az ilyen rendszernek tehát nem szerkezete változatlan újjáépitésének képességét kell megöriznie, hanem azt, hogy ,megtanulja” a változásokhoz való alkalmazkodást. Azt a képességét őrizze meg, hogy új, a hátrányok (következményeinek) csökkentését, egyszersmind az elönyök fölismerését és alkalmazását támogató müködési szabályokat, ellenörzési, visszacsatolási szervezeteket tud létrehozni..."

\footnotetext{
${ }^{24}$ O'Brien, Karen-Pelling, Mark-PATwardhan, Anand: Toward a Sustainable and Resilient Future, Coordinating. In: O'Brien, Karen-Pelling, Mark-Patwardhan, Anand: Managing the Risks of Extreme Events and Disasters to Advance Climate Change Adaptation. Special Report of the Intergovernmental Panel on Climate Change. Cambridge University Press, 2012, 563.

${ }^{25}$ O'BRIEN: i.m., 453.

${ }^{26}$ Bulla Miklós: Sokféleség és sérülékenység, A resilience képesség társadalmi interpretálása. In: Tamás Pál-Bulla Miklós (szerk.): Sebezhetőség és adaptáció, a reziliencia esélyei. MTA Szociológiai Kutatóintézet, Budapest, 2011, 24-25.
} 


\section{Reziliencia és kormányzás, reziliencia és önkormányzatok}

A fentiek alapján a reziliencia tartalmi elemei nem jelentenek újdonságot, de kezelése, egységes megjelenése, ekként való prezentálása mégis a részektől eltérő sajátosságokat képvisel. Mindenesetre egyre több helyen hivatkoznak erre, mint nyilvánvaló, közismert fogalomra. A hivatkozások sorát nem kívánom áttekinteni, csupán egyet emelek ki a legújabb megjelenések közül, mégpedig $a z$ EU 2016. évi ún. Globális Stratégiáját. ${ }^{27}$ A Stratégia fontosnak tartja a fogalmat is pontosítani, méghozzá a lehető legegyszerübb módon: „az államok és társadalmak képessége a megújulásra, aminek köszönhetöen képesek ellenállni a belsö és külsö válságoknak, illetve talpra állni azok után."28 Ugyanitt a reziliencia lényegét a fenntartható növekedés (és itt vegyük észre, hogy az EU 2010 óta $^{29}$ sajnálatos módon áttért a fenntartható fejlődésröl a fenntartható növekedés gondolatára; olvasatomban kifejezve egyben ennek a gazdasági érdekeknek való alávetettségét) alapjainak a megteremtésében látja.

A rezilienciát a külkapcsolatok esetében az EU elvárná a felé közeledö, vele kapcsolatba lépö tagjelöltektöl és közepesen fejlett vagy fejlődő országoktól, illetve ugyanezen elvárás a tagállamokkal, illetve magával az egész európai integrációval kapcsolatban is megjelenik. „Az EU meg fogja erösiteni az Uniót alkotó demokráciák rezilienciáját, és az Unió létrehozásában és fejlödésében kulcsszerepet játszó értékekhez méltó módon fog eljárni." Ugyanitt $\mathrm{fel}$ is sorolja a reziliencia legfontosabb összetevőit: „Ezekbe beletartozik az emberi jogok, az alapvetö szabadságok és a jogállamiság tiszteletben tartása és elömozdítása. Magukba foglalják a jogérvényesülést, a szolidaritást, az egyenlöséget, a megkülönböztetés tilalmát, a pluralizmust és a sokszínüség

\footnotetext{
${ }^{27}$ Közös jövőkép, közös fellépés: Erösebb Európa Globális stratégia az Európai Unió kül- és biztonságpolitikájára vonatkozóan.

http://www.eeas.europa.eu/archives/docs/top_stories/pdf/eugs_hu_.pdf

(2016. december 20.).

${ }^{28}$ Közös jövőkép, közös fellépés... i.m., 18.

29 A Tanács ajánlása, 2010/410/EU (2010. július 13.) a tagállamok és az Unió gazdaságpolitikáira vonatkozó átfogó iránymutatásokról, HL L 191, 23/07/2010 o. $0028-00$.
} 
tiszteletben tartását." ${ }^{30}$ A Stratégián belül máshol további összetevők egészítik ki a képet. „A társadalmi reziliencia megerösödése érdekében szorosabb kapcsolatokat fogunk kialakitani a civil társadalommal, különös tekintettel annak a kormányok elszámoltatására irányuló eröfeszitéseire... Azzal is tápláljuk továbbá a társadalmi rezilienciát, hogy fokozzuk az oktatás, a kultúra és az ifjúság terén végzett tevékenységeinket a pluralizmus, az együttélés és az egymás iránti tisztelet elömozdítása céljából., ${ }^{31}$

Összességében még a jellemzők között említést érdemel az is, ahogy a Stratégia megfogalmazza a reziliencia legfontosabb kapcsolódási pontjait, koordinátáit: „...a reziliencia tág fogalom, amely az egyéneket és az egész társadalmat is magában foglalja. A reziliens, demokratikus társadalom, az intézményekbe vetett bizalom és a fenntartható fejlödés adják a reziliens állam legfontosabb jellemzőit." ${ }^{32}$ Figyelemre méltó a demokratikus társadalom és a reziliencia közötti párhuzam, ami ugyancsak alátámasztja azt a nézetemet, mely szerint valójában nem új kategória jelenik meg, hanem a meglévő elemek közötti eltérő csoportosítás, hangsúlyeltolódás érzékelhető.

A magyar szakirodalom, szaksajtó is egyre nagyobb figyelmet szentel e kérdésnek, amire legjobb példa, hogy a Replika címü társadalomtudományi periodika nemrégiben egy teljes tematikus számban foglalkozott vele. ${ }^{33}$ Nem feladatom a tematikus szám ismertetése, annál is inkább, mert a szerzők számos ponton nem értenek egyet, de éppen a kormányzás - és természetesen ez jórészt az önkormányzati kormányzásra is vonatkoztatható - módszertani megújulásáról értekező cikk néhány figyelmet érdemlő gondolatára mutatok rá. ${ }^{34}$ A szerző a kormányzási struktúrák, irányultságok alapjait vizsgálja, mégpedig két alapvető irányvonalat állapítva meg: az „elörefelé” irányuló kormányzást és a „visszafelé” irányulót, amelyek között a fö különbség abban rejlik, hogy egy kormányzati célt kívánunk-e megvalósítani, kevéssé figyelemmel a körülöttünk

\footnotetext{
${ }^{30}$ Globális Stratégia 11.

${ }^{31}$ Globális Stratégia 21.

${ }^{32}$ Globális Stratégia 18.

${ }^{33} \mathrm{Ld}$. a folyóirat 2015/94. számát.

34 CHANDLER, David: A neoliberalizmuson túl: reziliencia, a komplexitás kormányzásának új módja. Replika, 2015/94, 25-44.
} 
történőkre, avagy figyelemmel vagyunk a körülményekre, a változásokra.

Chandler konklúziójának egy részlete szerint: „A kormányzás tehát - a probléma megjelenésének pillanatától - 'visszafelé' történik, nem pedig 'elörefelé', vagyis nem valamilyen kollektiv politikai cél megvalósítására törekszik. Ahhoz, hogy a megismerhetetlenség talaján állva lehetséges legyen a kormányzás, önreflexióra és reszponzivitásra van szükség egy gyorsan változó társadalomban, amelyben egyébként sem a piac, sem pedig az állam nem tünik képesnek a szükséges változások irányitására."35 A cikkben ezt még jobban is kiemeli, egyebek között aláhúzva: „A kormányzás alapját tehát már nem kinálati vagy célorientált instrumentális politika képezi, hanem sokkal inkább a már létezö folyamatok és képességek felismerése, illetve az, hogy ezeket hogyan lehet a politikai gondolkodás részévé tenni.",36

És most jutunk el az önkormányzatok szerepéhez, tényleges súlyának értékéhez - sok egyéb mellett - ebben a visszafelé történő kormányzásban, ${ }^{37}$ mert azok alapvető részesei az ún. mindennapi demokráciának. „A ,,mindennapi demokrácia” lényege a társadalmi kapcsolatok megerösitése, és nem sok köze van a képviseleti demokráciához, ami azt feltételezi, hogy a ,kimenetelekért” a kormányok felelösek, míg a társadalomra mindössze az a feladat hárul, hogy néhány évente passzívan elszámoltassa öket. A 'mindennapi demokráciának' nincs köze a 'felülröl lefelé' vagy az 'alulról felfelé' történö kormányzáshoz, ehelyett a társadalom rezilienciájára épül, amely az egyszerü emberekben meglévö relacionális képességeket veszi alapul.

Valójában minden szerző erre a sajátos követelményre mutat rá, és értékelésük alapvetően egybecseng, és mind támogatja az önkormányzatok mainál sokkal erőteljesebb szerepét, hiszen azok mérete és a problémához való közelsége - nevezhetjük ezt szubszidiaritásnak is - okán könnyebben, gyorsabban képesek reagálni. „Az adaptiv jogrendszerek feltétlenül elismerik a magánstruktúrák fontosságát, mint a jog, kormányzás, adaptív

\footnotetext{
${ }^{35}$ CHANDLER: i.m. 41-42.

${ }^{36}$ CHANDLER: i.m. 36.

${ }^{37} \mathrm{Az}$ informatikából kölcsönzött eredeti fogalmak szerint „,front-end” vagy „,backend" kormányzásról van tehát szó.

${ }^{38}$ CHANDLER: i.m. 38.
} 
kapacitás forrásait és helyét. Az adaptiv jog policentrikus struktúrája magában foglalja a jog kormányzati szereplőinek multiplicitását és kiterjedését (pl. az állami és helyi önkormányzatok erös szerepét, a regionális, hibrid és kvázi-közigazgatási kormányzati intézményeket, a vitarendezés vegyes formáit), akárcsak a nem-kormányzati struktúrák szerepét." ${ }^{39}$ Noha nem elemeztem, nem mutattam be az Olstrom és társai által körülírt modellek részleteit, az ott megfogalmazott és kiemelt tulajdonságok visszaköszönnek a jogiigazgatási struktúrák megteremtésének gondolataiban is. „A hatáskörök többféle központjának léte (policentrizmus) és a cselekvési megoldások többfélesége (multimodalitás) nem elegendöek, ha mindezt nem kíséri a szervezetek szintjeinek sokfélesége... Az adaptív jog központi szerepe, hogy a különbözö kormányzati szintek, funkciók, ökoszisztéma szintek és funkciók között megteremtse a kapcsolatokat, amely megköveteli a multimodalitás és a többszintüség együttesét.",40

Anélkül, hogy még további részleteket sorolnék, álljon itt csupán még egy hasonló gondolat (amelynek a témája az előzőekkel szoros kapcsolatban van) annak illusztrálása érdekében, hogy a különböző gondolkodók azonos téren mozognak. (Ami még közös a hivatkozott szerzők esetében, az az írások relatív újdonsága: mind az elmúlt 2-3 év termékeként jelentek meg.) A hivatkozott szerzők tudniillik a jog fejlesztésére tesznek javaslatokat, egyebek között az adaptív management és adaptív kormányzás irányában. ${ }^{41}$

A fentiekből és a most nem említett számos forrásból kirajzolódik, milyen irányt is mutat a reziliencia, ha azt a fenntartható fejlödéshez vezetö egyik alapvetö megoldási módszernek, útnak tekintjük. Mindezt a jogi és igazgatási rendszerekben is alkalmazni kell, különösen pedig a fenntarthatóságot legközvetlenebbül érintő jogterületen, a környezetjogon belül. „A 'reziliencia' a jogrendszer és a társadalom

\footnotetext{
${ }^{39}$ ARNOLD, Craig Anthony-Gunderson, Lance H.: Adaptive Law and Resilience. Legal Studies Research Paper Series Paper No. 2014-04, University of Lousville Law, Environmental Law Reporter 2013/5, 10433.

${ }^{40}$ ARNOLD-GUNDERSON: i.m., 10435.

${ }^{41}$ Garmestani, Ahjond S.-Allen, Craig R.-Ruhl, J. B.-Holling, C. S.: The Integration of Social-Ecological Resilience and Law. Nebraska Cooperative Fish \& Wildlife Research Unit - Staff Publications, Paper 144, 2014, 378-379. http://digitalcommons.unl.edu/ncfwrustaff/144/ (2016. december 20.).
} 
azon képességével kapcsolatos, ahogyan azok igazodnak a változó körülményekhez és azzal a móddal, amint a váratlant kezelik. Az adaptálódásnak ez a képessége különösen fontos a környezetjogban, hiszen a környezet és természeti eröforrásainak használata hosszú távú politikát igényel. A környezetjogban ennek megfelelöen a jövendö fejlödés bármilyen váratlan helyzetét figyelembe kell venni... Ezen túl, a jogrendszer vagy a mértékrendelkezések elfogadása igényli a rugalmasságot. Ez nyomban felveti a kérdést, mennyi rugalmasságot visel el a rendszer, miközben ott a jogszerüség követelménye is. A cél, hogy megfelelö egyensúlyt érjünk el a rugalmasság és a jogbiztonság között. Ezen túlmenöen pedig ott a kérdés, miként válaszolunk a komplexitás kihívására a jogi és társadalmi kérdésekben." 42

Az elméleti megközelítéseken túl azt kell valójában tisztázni, ha elfogadjuk a reziliencia követelményét, - és miért is ne tennénk, amikor jól láthatóan nem valamilyen eddig nem ismert újdonságról van szó, hanem a meglévő lehetőségek, intézmények megfelelő átértékeléséröl és egységes szemléletéröl - akkor melyek a megvalósitás peremfeltételei. Milyen intézményekre kell különösen figyelmet fordítani, miként segíthetjük elő a jog eszközeivel az alkalmazkodóképesség, a rugalmasság hatékonyabb elterjedését. És a címben jelzettekre válaszolva, így keríthetünk sort annak körüljárására is, miért tekinthető az önkormányzat reziliensnek, tehát miért lenne indokolt több lehetőséghez, nagyobb szerephez juttatni az önkormányzatokat, illetve miért is mutatható ki egyben azok nagyobb felelössége. Alapállásom e téren, hogy nem új eszközöket kell kitalálni, hanem a meglévőekben tudatosan felismerni, alkalmazni a lehetőséget.

\section{A reziliencia és annak jogi vonatkozásai, intézményesülése}

Amennyiben tehát a reziliencia jogi leképezésére törekszünk, azt több síkon, több úton lehet elérni, a megvalósíthatóság kiterjedése, gyakorlatiassága szempontjából különböző eszközcsoportokat feltételezve. Ide sorolandóak

\footnotetext{
${ }^{42}$ VAN Ruswick, Helena F.M.W.: The Road to Sustainability: How Environmental Law Can Deal with Complexity and Flexibility. Utrecht Law Review 2012/8, 7.
} 
- az elvi szinten is értékelhető intézmények, amelyek ugyanakkor feltételezik a megvalósítást, közelebb vagy távolabb állva a gyakorlattól;

- a konkrét jogintézmények, mindazok, amelyek leginkább alkalmasak a reziliens megközelítésre; illetve

- $\quad$ egyes államszervezési kérdések is.

A jogi elvek vagy elvi szintü, de közvetlenebb gyakorlati megvalósitást igénylö intézmények között kiemelendőek:

- A fenntartható fejlődés gyakorlati megvalósításának legjobb általános eszköze az integráció, értve ezalatt a külső integrációt, valójában ez áll legközvetlenebb kapcsolatban a fenntarthatósággal de természetesen a belső integrációt is, hiszen az általam egyértelmüen ökológiai szempontúnak tekintett fenntarthatóság külső integrációjának megvalósítása csak a belső koherencia megvalósulása mellett képzelhető el. Az 1995. évi LIII. tv. preambuluma erre az integrációra utal ,az emberi tevékenység és a természet közötti harmónia" fenntartása keretében, és ez az integráció jelenik meg az EUMSz 11. cikkében - csupán felvillantva egyes fontosabb példákat. Az integráció az önkormányzati szerep oldaláról nézve neutrális kérdés.

- A szubszidiaritás jelenti a következő általános elvi követelményt, mint a megfelelően hatékony szint megtalálásának „müvészetét." Valójában a reziliencia felé mutat Schumacher gondolkodása, - bár több mint 40 évvel ezelőtt ezt a fogalmat még a társadalmi viszonyokra nem alkalmazták - aki szépen fogalmazta meg a szubszidiaritás értelmét: ${ }^{43}$ "A fenti megfontolások adják a hátteret ahhoz, hogy kisérletet tegyek a nagyméretü szervezetek elméletének megfogalmazásához. Ezt most olyan formában teszem, hogy felállitok öt alapelvet. Az elsö alapelvet a szubszidiaritás elvének vagy a segédfunkciók elvének nevezik... A magasabb szintnek nem szabad magába olvasztania az alacsonyabb szint szerepkörét... szükség van egy másik elv betartására is. Ezt az elvet a védelmezés elvének fogjuk nevezni... ez az elv nagyon jól leírja a központi hatóságoknak az alsóbb alakulatokkal szembeni egyik legfontosabb kötelezettségét. A jó kormányzat mindig csak kivételesen avatkozik bele a dolgokba..." A szubszidiaritás egyértelmüen az

${ }^{43}$ SCHUMACHER, Ernst F.: A kicsi szép. KJK, Budapest, 1991, 250-259. 
önkormányzatiság erősítésének kedvez, elvárva annak megfelelő indokoltságát, ha egy feladatot vagy hatáskört a központosítás irányába mozdítunk el. A szubszidiaritás kapcsán nem feledkezhetünk meg arról, hogy ez egyben a lehetőségek korlátaira is emlékeztet minket, hiszen a hatékony szint nem feltétlenül a legalsó, hanem ami a legjobban megfelel a kérdéses feladatnak.

- Az elővigyázatosság minden, a fenntartható fejlődéssel bármilyen szinten is kapcsolatba kerülö értelmezés általános sajátossága. Ha a generációs méltányosság - értve itt különösen a jövő generációkat - adja a követelmények alapját, akkor a tudományos bizonytalanság megfelelő értelmezése éppen a lehetséges negatív következmények lehető legnagyobb mértékü elhárítására kell utaljon, hiszen nem lehetünk teljesen tisztában azzal, mi káros a jövő generációkra, illetve mik is a védendő majdani szükségletek. Az elővigyázatosság sokkal megnyugtatóbb eredményre vezet, mint a technikai megoldások mindenhatóságába vetett, megalapozatlan hit, amelyik bizonyosra veszi azt, hogy a „fejlödés" majd megteremti a megoldás kulcsait is.

- A reziliencia közkeletủ fogalomtára legalább két területen kapcsolódik az együttmüködés kérdéséhez. Ezek a policentrikusság és a multimodalitás. Már idéztük, hogy a „hatáskörök többféle központjának léte (policentrizmus) és a cselekvési megoldások többfélesége (multimodalitás)" mellett a szervezetek sokfélesége is szükséges. ${ }^{44}$ Amennyiben a hatáskörök megfelelő mértékben és arányban megoszlanak, illetve a cselekvésnek lehetőség szerint minél több útja alakul ki, akkor az egyes szintek és egyes cselekvések közötti koordináció, együttmüködés különös magyarázatot nem igénylő szükségletté válik. A szervezetek sokféleségét is hozzátéve az együttmüködés iránti igény még fokozottabban jelenik meg. Az együttműködés megoldásainak és szintjeinek diverzifikációja egyebekben is alapvető összetevője a reziliens megoldásoknak, ahol lehetöség szerint a döntések konszenzuson alapulnak és kevésbé a hatalmi szón - itt van ismét kiemelkedő szerepe az alulról felfelé vagy felülről lefelé kormányzás közötti megkülönböztetésnek. Az önkormányzatiság a maga struktúráival természetes helye az ilyen együttmüködésnek.

${ }^{44}$ Lásd 39. sz. lábjegyzet. 
- Az alkalmazkodás, az adaptivitás nem jelenti az ötletszerüséget, sőt éppen ellenkezőleg, igényli az előre elhatározott, tervezett lépések világos rendszerét, mert az lehet a megfelelö kiindulási pont, a megfelelö viszonyítási alap. A tervszerüség, lehetőség szerint a minél komplexebb tervezés ezért jelenik meg minden kortárs környezetvédelmi szabályozás ismérveként, a gyakorlati szükségből elvvé nemesedve, a tervek folyamatos újraértékelésével, visszacsatolásával, az eredmények ellenőrzésével. A tervezési visszacsatolásoknak pedig feltétlen következménye kell legyen a szükség szerinti változás, a felelősség megállapítása, a feladatok indokolt átrendezése. Mindez legalább annyira igaz az önkormányzatokra, mint bármely más szintre, a tervezés mindenütt általánosan kötelező elvárás.

- A rezilienciával kapcsolatos valamennyi nézet - legalábbis, amelyik a jogi vonatkozásokra is kitér - kiemelten kezeli az emberi jogok értékét és különösen ezek eljárásjogi garanciáit, megvalósításukat. Nem csupán a fenntarthatósággal, környezettel kapcsolatos jogokra kell gondolnunk, hanem minden olyan jogra, amelyik lehetőséget biztosít a rugalmasság és adaptivitás mellett a jog kötelezettségi oldalának erősítésére is. Ezzel együtt elsősorban a jogok, ezen belül tehát nem csupán a harmadik generációs jogok megfelelő megvalósítása lesz az elsődleges szempont. Természetesen az emberi jogok és a velük együttjáró kötelezettségek összességére kell figyelmet fordítani, hiszen a fenntartható fejlődés is szorosan kapcsolódik a gazdasági és szociális jogokhoz, a jogállamiságot biztosító politikai jogokhoz vagy a béke megóvásához egyaránt. Az emberi jogok az önkormányzatokkal összefüggésben szemlélve kevésbé rendelkeznek sajátosságokkal, ugyanakkor nem is lehet tölük ezen a szinten sem elvonatkoztatni.

$\mathrm{Az}$ emberi jogok közvetlenül fenntarthatósággal, környezettel kapcsolatos szelete eljárásjogi garanciái között kiemelt szerepe van a társadalmi részvétel minden pillérének - az Aarhus-i Egyezmény három plusz egy (információ, részvételi jogok, jogorvoslat és a részvételre képesítés) rendszerében gondolkodva. A társadalmi részvételt éppen ennek sajátos intézményi rendje miatt kell kiemelten kezelni, mert az nem csupán a környezeti jogok érvényesítésében, hanem valamennyi emberi jog életében elsőrendü szerepet kap. Az önkormányzatok esetében sem kisebb a társadalmi részvétel fontossága, sőt számos - különösen a döntéshozatali 
részvételhez kötődő - lehetőség közvetlenebbül jelenhet meg, mint a regionális vagy az országos szinteken.

A jogintézmények között - értve ezalatt különösen a fenntartható fejlödéshez, azon belül is kiváltképpen a környezetvédelemhez kapcsolódó jogi eszközöket - is számos olyat találhatunk, amelyik az átlagnál jobban alkalmas arra, hogy a reziliencia legfontosabb jellemzőit érvényre jutassa, mert mind alkalmas arra, hogy a változásokhoz jobban alkalmazkodjon, illetve elösegítse a jobb alkalmazkodást. Gondolhatunk különösen a következőkre:

- A környezeti hatásvizsgálat 1969-es, USA NEPA-beli ${ }^{45}$ megjelenésétől kezdve több olyan elözetes vizsgálati lehetöség létezik, jelent meg, amelynek az a célja, hogy a megalapozott döntéshozatalt támogassa, oly módon, hogy minél szélesebb merítéssel tárja fel a lehetséges következményeket. A környezetvédelmi törvény maga is tartalmaz néhány ilyen vizsgálati lehetőséget: a vizsgálati elemzést és ezzel szoros összefüggésben, de nem azonos körben - hanem éppen számos önkormányzati szintü döntéshez is kapcsolódóan - a környezeti vizsgálatot, ${ }^{46}$ az előzetes vizsgálati eljárást, ${ }^{47}$ illetve a környezeti hatásvizsgálatot. ${ }^{48}$ A négy vizsgálat közül az elsőt kivéve mindegyik rendelkezik a további részleteket megállapító végrehajtási szabályokkal. A különféle eljárások integrált szemléletet érvényesítenek, a tervezéshez és döntéshozatalhoz nyújtanak segítséget, társadalmi részvételi és együttműködési eljárási elemeket mutatnak fel, érvényesítik az elővigyázatosság elvét, tehát azokat az elvi szempontokat, amelyeket az előzőekben soroltam fel.

- Hasonlít a hatásvizsgálati típusú intézményekhez, de jobban koncentrál egy szempontra a kockázatelemzés, amely egyre több területen bukkan fel, mint kötelező elvárás, ugyancsak a döntéshozatalt megelőzve, ezzel a névvel vagy hasonló elnevezéssel. ${ }^{49}$ A hatásvizsgálat általában a környezeti hatásokat

45 Lásd például https://www.epa.gov/laws-regulations/summary-nationalenvironmental-policy-act (2016. december 20.).

${ }^{46}$ 1995. évi LIII. tv. 43-44. §.

${ }^{47}$ 1995. évi LIII. tv. 67. §

${ }^{48}$ 1995. évi LIII. tv. 68-69. §

49 Természetesen szerepel a kockázatelemzés a 2011. évi CXXVIII. törvényben (a katasztrófavédelemről és a hozzá kapcsolódó egyes törvények módosításáról), annak is 5. és 8. §-aiban, de megjelenik az erdötörvényben is (2009. évi XXXVII. tv. „54. § (1) Az erdészeti hatóság az erdősítés befejezetté nyilvánítását követö öt év elteltével 
fogja át, a kockázatelemzés inkább a potenciális balesetek elkerülésére, katasztrófahelyzetek megelözésére, tehát a hatásvizsgálathoz képest „élesebb” szituációk kezelésére irányul, és mint ilyen, hatókörében szükebb, részleteiben viszont alaposabb, mélyebb a hatásvizsgálatoknál. A kettő tehát nem felváltja, sokkal inkább erősíti egymást.

- $\quad \mathrm{Az}$ együttmüködési és önszabályozási típusú eszközök általában kiválóan alkalmasak a reziliencia megvalósítására. Az önszabályozási eszközök között erröl magam is írtam, ezért az egyszerüség kedvéért csak idézem a következö összegzést: ${ }^{50}, A z$ együttmüködési típusú eszközök nem jelentik a közigazgatási határozatok új típusát, sokkal inkább a meglévö közigazgatási és polgári jogi lehetöségek egyfajta egybeolvasztását, mégis oly módon, hogy a közhatalom, a közigazgatás kényszeritö ereje fennmaradjon. A közigazgatás szerveinek általában a jogalkotó valamilyen mértékü diszkrecionális jogkört biztosít, annak érdekében, hogy az általános feltételeket a realitásokhoz igazitsa. Emellett egyre inkább követelmény az, hogy a közigazgatás maga is aktivan és alakitóan vegyen részt a környezeti feladatok megoldásában. Ennek egyik lehetösége, hogy a közigazgatás a környezethasználókkal és a társadalom képviselöivel együtt értelmezni és adott körülményekhez igazitani próbálja a jogi kereteket, mégpedig a másik két szereplövel együttmüködésben. Az együttmüködés öltheti valamely megállapodás formáját is." Ugyanott az önkéntes megállapodások típusait is áttekintem, amelyek itt is alkalmazhatóak, és amelyeket nem ismétlek meg. Az ilyen eszközök között példaként említhető a nem jól kihasznált hatósági szerződés ${ }^{51}$ intézménye. Természetesen az együttműködés kiváló terepeként utalhatunk az önkormányzati társulások lehetőségére is.

- A különbözö ösztönzési lehetöségek, rendszerek nem feltétlenül csupán a gazdasági ösztönzést jelentik. Ide sorolható az egyébként az önkéntes eszközökkel is közvetlen kapcsolatban lévő környezeti menedzsment eszközök alkalmazása is, amelyek

kockázatelemzés alapján felülvizsgálja az erdő állapotát.”) vagy a 2011. évi CLXVIII. törvényben (a mezőgazdasági termelést érintő időjárási és más természeti kockázatok kezeléséröl) 14. § (3) bekezdés.

${ }^{50}$ BÁNDI Gyula: Környezetjog. Szent István Társulat, Budapest, 2014, 292.

${ }^{51}$ 2004. évi CXL. tv. (Ket.) 76-77. § 
ugyanúgy rendelkezésre állnak egy önkormányzat vagy más közigazgatási szerv számára, mint bármely gazdálkodó szervezetnek. ${ }^{52}$ Természetesen a gazdasági ösztönzők lehetősége még ennél is több lehetőséget, több variációt jelent, ${ }^{53}$ akár a helyi adók, területhasználati díjakra vonatkozó kedvezmények, és sokan mások színesíthetik a palettát.

- A jogi eszközök megfelelő alkalmazásának egyik kulcsa a megfelelö, megalapozott mérlegelés, a jó értelemben vett - és nem az önkényességet jelentő - diszkrecionalitás. A megfelelö döntéshozatal a körülmények gondos feltárását, a döntések ehhez igazítását várják el, tehát különösen a tényleges helyzetek megfelelő mérlegelését kell megteremteni, majd a következőkben említett további eszközökkel is megtámogatni a megfelelö végrehajtást, a hatékony érvényesülést.

- A reziliencia a döntések, más lépések folyamatos nyomon követését igényli, amelynek folyománya lesz a következőként említett döntés-felülvizsgálat. A nyomon követés az ellenörzés és/vagy monitoring, valamint a visszacsatolás révén valósítható meg legjobban. Ugyancsak utalok arra, amit már máshol leírtam: „Mindenféle közigazgatási beavatkozás, illetve felelösség megállapitásának elöfeltétele a megfelelö ellenőrzés, melynek révén $a$ hatóság információkat gyüjt egy környezethasználó tevékenységröl. Az ellenörzésnek számos megvalósitási módja lehetséges, az eseti ellenőrzéstöl a folyamatos figyelemmel kisérésig. Az ellenörzés feladataiban a társadalom, a közigazgatási szervek és maguk a provizórikus szennyezök osztozhatnak. A különbözö ellenörzési lehetöségek természetszerüen más és más szabályozással és kötelezettségekkel járnak. A közigazgatáshoz kapcsolódó ellenörzés lehetőségeit három nagy csoportra oszthatjuk: - önellenörzés (amely távolról sem azonos az önkéntes ellenörzéssel!), - társadalmi ellenörzés, - hatósági ellenörzés." ${ }^{54}$

- A visszacsatolás elsődleges érdeme, hogy muníciót biztosít a kiterjedt döntés-felülvizsgálathoz, hiszen a reziliencia egyik alapja

\footnotetext{
${ }^{52}$ Pl. az Európai Parlament és a Tanács 1221/2009/EK rendelete (2009. november 25.) a szervezeteknek a közösségi környezetvédelmi vezetési és hitelesítési rendszerben (EMAS) való önkéntes részvételéről és a 761/2001/EK rendelet, a 2001/681/EK és a 2006/193/EK bizottsági határozat hatályon kívül helyezéséről.

${ }^{53}$ Itt a Környezetjog c. könyvem XII. fejezetére utalok példaként.

${ }^{54}$ BÁNDI: i.m. 307.
} 
a korrekció, a folyamatos kiigazítás lehetősége, a megváltozott körülményekhez történő igazodás, igazítás. A döntés-felülvizsgálat elsősorban természetesen nem a hatósági döntésekre irányul, mert az ellenkezne a jogbiztonság iránti elvárásokkal, hanem egyéb, középés hosszútávú döntésekre, tervekre, beruházásokra, stb., még a jogszabályok korrekcióját is értve ez alatt - ha nem is olyan mértékben, amint pl. az manapság a hulladékgazdálkodás jogi alapjai esetében történik ${ }^{55}$ - a szükséges és indokolt esetben.

- Végezetül minden további részlet említése nélkül és összességében mindenek felett áll a komplex, minél több lábon álló rendszerek kialakításának elvárása. Az eddig említett jogintézmények tehát nem külön-külön, hanem elsősorban együtt teszik rezilienssé a rendszereket.

Harmadik csomagként az államszervezési kérdéseket kell figyelembe venni, beleértve természetesen az önkormányzatiságot is.

- A decentralizáció, illetve általában az önkormányzatiság megnövekedett jelentősége a reziliens megoldások természetes velejárója, figyelemmel ugyanakkor a szubszidiaritás kapcsán előtérbe kerülő hatékonyság követelményére. Az önkormányzatiság ebben az összefüggésben ugyan elsősorban a helyi önkormányzatokat jelenti, de nem kizárólag erre mutat, hanem a szakmai-gazdasági önkormányzatiságra is. Jó példája ennek a szabvány, amelynek törvényi fogalma ${ }^{56}$ szerint: „4. §(1) A szabvány elismert szervezet által alkotott vagy jóváhagyott, közmegegyezéssel elfogadott olyan müszaki (technikai) dokumentum, amely tevékenységre vagy azok eredményére vonatkozik, és olyan általános és ismételten alkalmazható szabályokat, útmutatókat vagy jellemzöket tartalmaz, amelyek alkalmazásával a rendezö hatás az adott feltételek között a legkedvezöbb." Az adott feltételek között legkedvezőbb hatást alkalmasint az adott tevékenységet folytatók, az adott körülményeket jól ismerök által alkotott szabályok hatékonyabban képesek megvalósítani, mint a központi megoldások.

- A dekoncentráció a fenti gondolatmenet folytatása, az adott szervezeti rendszeren belül maradva, ugyancsak közelebb kerülve a

55 Nem hiába írta le több mint két éve (2014. decemberében) az Országos Környezetvédelmi Tanács, a hulladékos szabályozás akkori állapotáról szóló 15 pontjában elsőként: „, 1. folyamatos változásnak van kitéve, ... senki sincs tisztában az aktuális követelményekkel..."

${ }^{56}$ 1995. évi XXVIII. törvény a nemzeti szabványosításról. 
felmerülö problémához. Akárcsak a decentralizáció, a dekoncentráció sem automatikusan jobb megoldás, hanem az adott helyzethez viszonyítva, de ez az adaptivitás egyik természetes következménye.

- Ugyancsak generálisan alkalmazandó a minél szélesebb körü, társadalmi és szakmai-tudományos, illetve gazdasági kérdéseket egyaránt átfogó konzultáció. A megfelelő döntéshozatal számos olyan szerv müködésével alapozható meg, mint a már említett Országos Környezetvédelmi Tanács, amelyet még a környezetvédelmi törvény ${ }^{57}$ hozott létre, vagy az újabb, az Országgyülés által 2008-ban létrehívott Nemzeti Fenntartható Fejlödési Tanács, az önkormányzatok környezetvédelmi, településfejlesztési kérdésekkel foglalkozó bizottságai, stb. Ezen intézményesült formák közé tartoznak a jogalkotásban érvényesülő stratégiai partnerségi megállapodások,${ }^{58}$ de számos nem ennyire formalizált, ad hoc lehetőség is megjelenik. A cél mindenképpen azonos, a már említett, megalapozott döntés.

- $\quad$ Az együttmüködés kapcsán említett társulási lehetőségek is ebbe a körbe tartoznak, ismét az intézményesült megoldások felé mutatva, ami e téren sem jelenthet kizárólagosságot.

- Ugyanez mondható el a kooperáció más formáiról, mint az együttmüködés szervezeti megvalósításának egyképpen fontos eszközeiről, amely a társulásnál kevésbé kötött, ezért szélesebb körben alkalmazható.

- Mindezek egyik manapság kissé indokolatlanul mellőzött vonatkozása a civil szféra rendszereinek diverzitása és bevonása mind az elökészítésbe, mind a döntéshozatalba, mind a végrehajtásba és a visszacsatolási, ellenőrzési folyamatokba. Minderröl már a társadalmi részvétel elvénél is volt szó, e téren ezek szervezeti formáinak megfelelő megoldásaira kell gondolnunk.

- Összességében az eddig elmondottak a nélkülözhetetlen transzparenciát segítik elö, amely a környezetvédelemben különösen fontos társadalmi bizalom erősítésében játszik szerepet. Az egyben természetesen a fenti eszközök alkalmazásához is alapot ad, ebböl

\footnotetext{
${ }^{57}$ 1995. évi LIII. tv. 45. §.

58 2010. évi CXXXI. törvény a jogszabályok elökészítésében való társadalmi részvételröl.
} 
következően elsődlegesen az emberi jogok, a társadalmi részvétel, az együttmüködés, az ellenörzés erősítése érdekében.

\section{Zárógondolatok}

A reziliencia, mint az alkalmazkodás, a nyomon követés, a rugalmasság, adott esetben némileg ,a kicsi a szép" módszere feltételezi, támogatja az önkormányzatok okszerü - a szubszidiaritás elvére alapozott - müködését. A környezeti problémák jelentős része helyi szinten érzékelhető, és számos esetben ott is oldható meg. Amikor ezeket a sorokat írom (2016/17 telén), éppen a szmoghelyzet jelent komoly veszélyt a lakosság egészségére. Ennek okai között a lakossági fütés, az intézményi fütés, a közlekedés játszik elsődleges szerepet. Mindegyik elsődleges okozó megoldása nagyrészt az önkormányzatok kezében van, de legalábbis az önkormányzatok hozzásegíthetnek a megoldáshoz. Úgyszintén alighanem hatékonyabb helyi szinten a szelektív hulladékgyüjtést megszervezni, mint központosítva. Számos természeti vagy ember alkotta védendő értékről helyi szinten rendelkeznek a legtöbb ismerettel. Ha mozgósítani kell, - akár a környék takarítására, elhagyott hulladék gyüjtésére - ha a társadalmat tájékoztatni kell, a kezdeményezés persze lehet országos, de a kivitelezés semmiképpen sem. És visszatérhetünk a településgazdai szemlélethez, elsődlegesen a település területe használati arányainak kialakításával kezdve, amely ugyancsak olyan feladat, ami nem oldható meg máshol, mint a települési önkormányzatok szintjén.

Az önkormányzatok egyszerüen nem kerülhetők meg. Éppen ezért sokkal indokoltabb lehetőségeik, energiáik megfelelő kiaknázása, mint azok visszaszorítása. Az önkormányzatokat szövetségessé kell tenni, semmiképpen sem elbizonytalanítani. A reziliencia éppen azt várja el, hogy minden szint, szakma, terület energiáit felhasználva együttesen érjünk el eredményeket. Ez pusztán a kormányzás bölcsességén múlik. 


\title{
HELYI KÖRNYEZETPOLITIKA - GÖRÖNGYÖK AZ ÚTON
}

\author{
Pump Judit ${ }^{*}$
}

A rendszerváltozás óta jelentős változások következtek be, melyek a helyi környezetpolitikát közvetlenül, illetve közvetve is érintették. $\mathrm{Az}$ alábbiakban e változások közül emelünk ki néhányat, melyek véleményünk szerint a leginkább befolyásolták a helyi környezetpolitika alakulását. Jelen tanulmányt figyelemfelhívónak szánjuk, rámutatva azokra a kapcsolatokra, melyek tudományos és rendszerszintű vizsgálatát a jövőben szükségesnek tartjuk.

\section{Mi a helyi környezetpolitika?}

A helyi önkormányzatok környezetvédelmi politikájának értékelését fogalmi kérdések tisztázásával kell kezdenünk. Először is tisztázandó, mit is értünk környezetpolitikán, és mi teszi azt „helyivé."

\subsection{Meghatározható-e a környezetpolitika?}

A környezetjogot, illetve környezetpolitikát tárgyaló - gyakran tankönyvként is használt - könyvek ${ }^{1}$ nem határozzák meg a

* Dr. Pump Judit PhD, az Alapvető Jogok Biztosának Hivatala munkatársa; c. egyetemi docens, Pázmány Péter Katolikus Egyetem Jog- és Államtudományi kar, Budapest. A tanulmány a szerző saját véleményét tartalmazza.

${ }^{1}$ BÁNDI Gyula: Környezetjog, Szent István Társulat, Budapest, 2014, 145. Fodor a magyar környezetpolitika kapcsán a nemzeti környezetvédelmi programokat említi, mint a környezetpolitika hivatalos dokumentumait. FODOR László: Környezetjog. Debreceni Egyetemi Kiadó, Debrecen, 2014, 75, 79. HoRVÁTH Zsuzsanna: Az Európai Unió környezeti politikájának kialakulása. In: Bándi Gyula (szerk.): $A z$ Európai Unió környezetvédelmi szabályozása. KJK Budapest, 1999, 34. VÁRNAY Ernő-PAPP Mónika: Az Európai Unió joga. Complex Kiadó, Budapest, 2006, 806814, HoRvÁth Zsuzsanna: Környezeti politika. In: Kengyel Ákos (szerk.): $A z$ 
környezetpolitika fogalmát, vagy annak kapcsán hivatkoznak az Európai Közösség első környezetvédelmi akcióprogramjára. ${ }^{2}$ Horváth szerint az „,...elsö Akcióprogram a Közösség Környezeti Politikájának alapjait rakta le azzal, hogy elsö izben adott e területen átfogó programot a Közösség számára, megfogalmazva a Közösség által követendö környezeti politika napjainkban is érvényes céljait és alapelveit." "3 Az akcióprogram első, általános részében a célok és elvek mellett találjuk a Közösség környezettel kapcsolatos tevékenységét meghatározó programok általános leírását, prioritásait és időkertét. A második rész, már a tevékenységek részletes leírását tartalmazza, kitérve a fellépés indokaira, céljára, a Bizottságra vonatkozó eljárásokra és határidőkre, a finanszírozás alapjaira, a környezettudatosság növelésének módjára, a tagállamok közötti és a nemzetközi együttmüködésre. Napjainkig, az Európai Bizottság hét akcióprogramot dolgozott ki, melyek egymásra épülnek ugyan, de tartalmukban jelentős különbséget is mutatnak. ${ }^{4}$

Európai Unió közös politikái. Akadémiai Kiadó, Budapest, 2010, 305-347. VARJÚ Viktor: Környezetpolitika és/vagy területfejlesztés. Dialóg Campus Kiadó-Dóm Kiadó, Budapest, 2015.

${ }^{2}$ Declaration of the Council of the European Communities and of the representatives of the governments of the member states meeting in the Council of 22 november 1973 on The Programme of Action of the European Communities on the Environment. OJ 20.12.1973, No C $112 / 1$.

${ }^{3}$ HoRVÁTH (1999): i.m., 34.

${ }^{4}$ Vesd össze: Declaration of the Council of the European Communities and of the Representatives of the Governments of the Member States, meeting in the Council on the programme of action of the European Communities on the environment, HL C 112/1, 20. 12. 1973; Resolution of the Council of the European Communities and of the Representatives of the Governments of the Member States, meeting within the Council on the continuation and implementation of a European Community policy and action programme on the environment, HL C 139/1, 13. 06. 1977; Resolution of the Council of the European Communities and of the Representatives of the Governments of the Member States, meeting within the Council on the continuation and implementation of a European Community policy and action programme on the environment (1982 to 1986), HL C 46/1, 17. 02. 1983; Resolution of the Council of the European Communities and of the Representatives of the Governments of the Member States, meeting within the Council on the continuation and implementation of a European Community policy and action programme on the environment (19871992), HL C 328/01, 07. 12. 1987; Resolution of the Council and the Representatives of the Governments of the Member States, meeting within the Council on a Community programme of policy and action in relation to the environment and sustainable development, HL C 138/1, 17. 05. 1993; Towards Sustainability: An European Community programme of policy and action in relation to the environment 
A környezetpolitika szóösszetételben a „környezet” szó jelentése nem tekinthető állandónak. Erre hívja fel a figyelmet az uniós környezetpolitika átvételével foglalkozó tanulmánykötetben Jordan és Liefferink. ${ }^{5}$ Szerintük a ,környezetpolitika abból a hagyományos antropocentrikus megközelitésböl nött ki, mely a középpontba az emberi egészséget helyezte. Ebböl fejlödött ki egy ökocentrikusabb megközelités, mely már magában foglalja az ökológiai rendszer egészét érintö környezetromlás elleni fellépés szükségességét. A 'fenntartható fejlödés' gondolatisága a környezetpolitikát az 1990-es években összekapcsolta a gazdasági és a társadalmi kérdésekkel, ugyanakkor a természeti eröforrások megörzése már a 19. század végi állami közpolitikák kiemelt céljai közét tartozott. ",6 A tíz ország ${ }^{7}$ környezetpolitikájának összehasonlítása érdekében Jordan és Liefferink a ,politika"(policy) ${ }^{8}$ szó fogalmát határozza meg. Eszerint a politika három fó elemböl áll: 1) a politika tartalma (a tevékenységek megközelítésének alapja, a célok és a politika eszközei); 2) a jogi és igazgatási rendszer (amit a politika követésére, megvalósítására hoztak létre); 3) a politika létrehozásának és végrehajtásának módja, stílusa. ${ }^{9}$

A tíz ország környezetpolitikáját összehasonlító elemzésen keresztül megállapítható, hogy bár a legáltalánosabb célokban - a természetes környezet és az életminőség védelme - és alapelvekben azonosságot mutatnak, az uniós kötelezettségen túl abban már jelentős különbség van köztük, hogy milyen területeket tekintenek a környezetpolitika részének, milyen eszközökkel kívánják a célokat

\footnotetext{
and sustainable development, HL C 138/5, 17. 05. 1993; Az Európai Parlament és a Tanács 1600/2002/EK határozata a hatodik közösségi környezetvédelmi cselekvési program megállapításáról, HL L 242/1, 2002. 07. 22.; Az Európai Parlament és a Tanács 1386/2013/EU határozata a Jólét bolygónk felélése nélkül címü, a 2020-ig tartó időszakra szóló általános uniós környezetvédelmi cselekvési programról, HL L 354/171, 2013.12.28.

5 Jordan, Andrew-LiEFFERINK, Duncan: Measuring Europeanization and Policy convergence. In: Jordan, Andrew-Liefferink, Duncan, (eds.): Environmental Policy in Europe - The Europeanization of national environmental policy. Routledge, London, New York, 2005, 30-43.

${ }^{6}$ JORDAN-LIEFFERINK: i.m., 32.

7 Ausztria, Egyesült Királyság, Finnország, Franciaország, Hollandia, Írország, Németország, Norvégia, Spanyolország, Svédország.

${ }^{8}$ A magyar politika szó önállóan nem igazán alkalmas az angol policy tartalmának kifejezésre, ezért általában szóösszetételekben használjuk.

${ }^{9}$ JORDAN-LIEFFERINK, i.m., 1-13 (a szerző fordítása).
} 
elérni, milyen jogi és igazgatási rendszert alakítanak ki, milyen eljárási, szervezeti megoldások jellemzik megalkotásukat és végrehajtásukat. Mindebből azt a következtetést vonhatjuk le, hogy a környezetpolitikának nincs egzakt fogalma, annak ellenére, hogy a gyakorlatban a jogharmonizációs követelmények miatt az Európai Unióhoz tartozó országokban az évek során a környezeti akcióprogramok hatására a környezetpolitika megkülönböztethetővé vált más szakpolitikáktól, elsősorban célja miatt. A környezetpolitika általános célja az emberi tevékenység alakitása a környezetre, az emberi élet minöségére (az emberi egészségre) gyakorolt (és várható) hatásai alapján, függetlenül attól, hogy adott tevékenység mely gazdasági ágazathoz tartozik. Ebböl adódik a környezetpolitika átfogó, horizontális jellege.

\subsection{Mitöl lesz helyi a ,helyi”?}

A következő tisztázandó kérdés, hogy a környezetpolitika elött álló - helyi - jelzőnek mi a tartalma. Ha helyi környezetpolitikáról beszélünk, akkor a helyi szó jelentését többféle megközelítésböl is értelmezhetjük. A helyi környezetpolitika alapja lehet a helyi közügy. Arra nézve, hogy mi tekinthetö olyan helyi közügynek, ami a környezetpolitika hatálya alá tartozik, eligazítást a helyi önkormányzatokról szóló törvényből, a környezetvédelmi törvényből, valamint az önkormányzati jogalkotás terjedelmével kapcsolatos alkotmánybírósági, illetve kúriai döntésekböl kaphatunk. Ezek alapján megállapítható, hogy e körbe tartozik elsősorban a lakosság közszolgáltatásokkal való ellátása, ${ }^{10}$ a helyi környezetvédelmi program által szabályozandó területek, ${ }^{11}$ valamint a helyi társadalmi viszonyok. ${ }^{12} \mathrm{~A}$ fogalom meghatározásához

\footnotetext{
${ }^{10}$ Ezt emeli ki mind az első, mind a második, önkormányzatokról szóló törvény. Lásd: 1990. évi LXV. tv. 1.§ (2) bekezdés, 2011. CLXXXIX. tv. 4.§.

${ }^{11}$ Lásd 1995. évi LIII. tv. (Kvt.) 47. §-át, illetve 2009 után a 48/E. §-t.

${ }^{12}$ Az Alkotmánybíróság és a Kúria az önkormányzati rendeletalkotás terjedelmét részben az alapján vizsgálja, hogy az mennyiben helyi társadalmi viszony szabályozására született (pl. 142/2011. (XII. 2.) AB határozat: „A törvény által nem szabályozott helyi társadalmi viszonyok körében a közterület-használat szabályozása az Alkotmány és az Ötv. idézett rendelkezései alapján az önkormányzat jogalkotó hatáskörébe tartozik..." A Kúria önkormányzati tanácsának Köf.5.003/2014/4. ügyszámú határozata: „Az Alaptörvény 32. cikk (1) bekezdése „a helyi közügyek intézése körében törvény keretei között" hatalmazza fel a helyi önkormányzatokat
} 
kiinduló pontul felhasználhatjuk a közigazgatási határokat is, és mondhatjuk, hogy helyi környezetpolitikán azt a politikát értjük, mely meghatározza, befolyásolja a helyi önkormányzat közigazgatási területén belül az ott élök, illetve a gazdasági szereplők tevékenységét, a környezet állapotát. ${ }^{13}$ A „,helyi” jelzőt azonosíthatjuk a helyi döntéshozatallal is, mely esetben helyi környezetpolitikán csak azt értenénk, ha a döntést helyi szinten hozzák meg.

\subsection{A helyi környezetpolitika az életröl szól}

A környezetpolitika kapcsán ritkán esik szó arról, hogy életünket, létezésünk alapját két szempontból is meghatározza azzal, hogy közvetve és közvetlenül befolyásolja a környezet állapotát. Az ember, mint természeti lény fizikai létezéséhez egyrészt szükséges a természetes környezet megfelelő állapota ${ }^{14}$ (különösen a levegő minősége), másrészt élelem és víz. Az egyén ez utóbbiakat úgy is megszerezheti, hogy közben az elsőt veszélyezteti. Az utóbbi kettő hiánya az egyén számára, mint közvetlen életveszély azonnal érzékelhető, és mindaddig fennáll, amíg a szükségletet ki nem elégíti, többnyire valamilyen munkával szerzett jövedelemböl. ${ }^{15}$

rendeletalkotásra. A korábbi törvényi szabályt emelte az alkotmányozó az Alaptörvény 32. cikk (2) bekezdésébe, amely szerint: „Feladatkörében eljárva a helyi önkormányzat törvény által nem szabályozott helyi társadalmi viszonyok rendezésére, illetve törvényben kapott felhatalmazás alapján önkormányzati rendeletet alkot."

${ }^{13}$ A környezetvédelmi törvény a helyi környezet ügy fogalmát határozza meg, és szükíti azt le a közigazgatási területre: „4. § r) helyi környezetvédelmi ügy: minden olyan környezetvédelmi ügy, amelyben a környezet használata és a hatásterület nem terjed túl az érintett települési önkormányzat területén." Megjegyzendö, hogy a környezetvédelmi ügy fogalmát a törvény nem határozza meg.

${ }^{14}$ Az Alkotmánybíróság az egészséges környezethez való jog értelmezésekor - az 1990-es évek elejétől az Alaptörvény hatályba lépése után is - a környezet védelmére, mint az élet természeti alapjainak védelmére tekintett. Lásd: 996/G/1990. AB határozat, 28/1994. (V. 20.) AB határozat, 16/2015. (VI. 5.) AB határozat.

15 Az Alkotmánybíróság a munkához (a foglalkozás szabad megválasztásához) való jog értelmezése során több határozatában is utalt arra, hogy a jövedelem a jövedelemszerzö és családja számára a létfenntartás alapja. 8/2011. (II. 18.) $\mathrm{AB}$ határozat, 3101/2015. (V. 26.) AB határozat. Stumpf István alkotmánybíró ebből a szempontból párhuzamos indokolásában egészen egyértelmüen fogalmaz, szerinte , $a$ munkához (foglalkozáshoz, vállalkozáshoz) való jognak az az elsödleges funkciója, hogy biztositsa az emberi létfenntartáshoz (megélhetéshez) szükséges javak elöteremtését." 8/2011. (II. 18.) AB határozat 49, 111-112. Hasonló véleményt 
Mindebböl következik, hogy az egyén életének veszélyeztetéseként éli meg munkahelyének elvesztését, míg a természeti állapot romlását jellemzően nem értékeli annak, mert közvetlen életveszélyként csak ritkán jelenik meg; ${ }^{16}$ jellemzőbb, hogy az egészségrontó hatás csak hosszú távon jelentkezik.

E kettősséget tükrözi a környezetterhelő magatartást folytató és az azt elviselő személye közötti konfliktus. A helyi környezetpolitika feladata többek között e két érdek közötti egyensúly megteremtése. ${ }^{17}$ A környezethasználó és a teherviselő személye nem feltétlenül válik szét. Az a helyi lakos, aki a környezetterhelőtől kapja jövedelmét, egyszerre tekintendő terhelönek és teherviselőnek. Ebben az esetben az egészségkárosítással járó környezethasználatot az egyén belső konfliktusként éli meg, a fent jelzett kettősség miatt. Ha a jövedelemszerzés lehetőségének elvesztése, vagy hiánya saját és családjának megélhetését közvetlenül veszélyezteti, és nincs lehetősége arra, hogy a települést elhagyja, és új munkahelyet találjon, akkor valószínüsíthetően a környezethasználó mellé áll. ${ }^{18}$ Más a helyzet, ha a helyi lakos „csak” teherviselö, vagy ha jövedelemszerzése függ a természet állapotától, az állapot romlásától. ${ }^{19}$ Ekkor a környezethasználó és a teherviselő konfliktusa nyílt, az önkormányzat számára is érzékelhetően jelenik meg.

nyilvánított Bragyova András alkotmánybíró különvéleményében, amikor az Alaptörvény XII. cikk (1) bekezdés értelmezése során megállapította, hogy „, $[e] z a z$ alapjog minden társadalmilag elfogadott, megélhetést - a létfenntartáshoz szükséges jövedelmet - biztositó tevékenység szabadságát biztositja mindenki számára." 3380/2012. (XII. 30.) AB határozat [29].

${ }^{16}$ Ilyen volt a tiszai ciánszennyezés, vagy a vörösiszap katasztrófa, illetve ilyennek tekinthető az ivóvízhálózatba kerülő szennyezés, ha emiatt a vízszolgáltatást felfüggesztik.

17 A környezeti konfliktusokat elemző munkájában Szirmai a környezeti érdek fogalmát így fogalmazta meg: „A környezeti érdek társadalmi jelenség, amely a környezet és a társadalom történetileg változó kapcsolatrendszerében alakul, a környezeti károk társadalmi megnyilvánulását, a környezet védelmének, a természeti érdekek kifejezésének, képviseltének és érvényesitésének társadalmi igényét és megvalósitását fejezi ki." SZIRMAI Viktória: A környezeti érdekek Magyarországon. Pallas Stúdió, Budapest, 1999, 19.

${ }^{18}$ E jelenségre is utal Szirmai a környezeti konfliktusok kapcsán. SZIRMAI: i.m., 52, 156.

${ }_{19} \mathrm{Az}$ ipari létesítmények negatív hatása miatti fellépéseket nézve megállapítható, hogy sikerükhez jelentős mértékben hozzájárult a mezőgazdaságból élők gazdasági érdeke és érdekérvényesítése (például az akkumulátorhasznosító beruházás meghiúsítása Tokaj közelében. SzIRMAI: i.m., 58-59.). 
A helyi környezetpolitika szempontjából a környezethasználók és teherviselök közötti nyílt konfliktusok között különbséget kell tennünk aszerint, hogy a környezetterhelö a helyi gazdaság szereplöje, vagy csak lakos. Az első esetben az önkormányzatot nem tekinthetjük semleges félnek, hiszen a gazdálkodó szervezet létezése, müködése az önkormányzat más politikáinak megvalósítására is hatással van, míg a lakosok közötti konfliktusban a helyi együttélési szabályok kialakítását, érvényesítését segíti. Megjegyzendő ugyanakkor, hogy a környezeti konfliktusok rendezésében a helyi politikai érdekek mindig tetten érhetőek. ${ }^{20}$

A fentiekre is tekintettel a helyi környezetpolitikán a továbbiakban olyan politikát értünk, mely a helyi környezeti, gazdasági és társadalmi viszonyokhoz igazitva határozza meg a környezetpolitika tartalmát, jogi és igazgatási rendszerét, megalkotásának és végrehajtásának eljárási és szervezeti rendjét úgy, hogy közben megteremti az egyensúlyt a környezeti teherviselök és környezeti terhelök között. Mindez azonban nem jelenti azt, hogy az ezzel kapcsolatos döntések teljes egészében a helyi önkormányzatot illetik meg, hiszen döntési szabadságát az alkotmányos és törvények adta keretek korlátok közé szorítják.

\section{A helyi környezetpolitika tartalma}

A helyi környezetpolitika eszközeinek számbavétele előtt szükséges a helyi környezetvédelmi programhoz való viszonyának vizsgálata. Majd ezt követően azt elemezzük, hogy az elmúlt évek során az önkormányzat a helyi környezetpolitika érvényesítésére milyen eszközökkel rendelkezett.

\subsection{A helyi környezetpolitika és a helyi környezetvédelmi program}

A környezetvédelmi törvény vezette be, hogy a nemzeti környezetvédelmi programhoz igazodóan az önkormányzatoknak

\footnotetext{
${ }^{20}$ Ezt mutatja például, hogy a helyhatósági választások előtt a jegyzők nem hajtották be mindig a hulladékkezelési közszolgáltatás díjhátralékát. PuMP Judit: A jog hatása a fenntartható közszolgáltatásra a hulladékgazdálkodás és a vizgazdálkodás területén (PhD disszertáció) ELTE, Budapest, 2012.
} 
helyi környezetvédelmi programot kell készíteniük. $^{21} \mathrm{~A}$ környezetvédelmi törvény sorolja fel a program tartalmi elemeit. ${ }^{22} \mathrm{~A}$ program - ahogy azt korábban már jeleztük - a politika összefoglaló dokumentuma, mely 2009-től két fö részből áll. ${ }^{23} \mathrm{Az}$ általános rész helyzetértékeléssel kezdődik, ezt követi a fenntartható fejlödési célokkal összhangban álló célok és célállapotok, valamint a szükséges intézkedések felsorolása, a megvalósítás ütemezése, szabályozási, ellenőrzési és értékelési eszközei, finanszírozásának forrásai. A nemzeti környezetvédelmi program kapcsán a jogalkotó külön nem határozta meg azt, hogy a programnak milyen területekre kell kiterjednie. 1997-től napjainkig négy nemzeti környezetvédelmi program született, melyek a jelentős különbségek ellenére a környezetvédelme mellett foglalkoztak a környezet állapota és az ember egészsége közötti kapcsolattal, a környezet-egészségügyi kérdésekkel is.

A nemzeti környezetvédelmi programmal ellentétben a környezetvédelmi törvény felsorolja a helyi program alá tartozó szakmai területeket. Ha abból indulunk ki, hogy a környezetpolitika célja kettős: a természetes környezet és az életminőség védelme, ami azt jelenti, hogy a környezetpolitikán belül értelmezendő a környezet állapota és az emberi egészség közötti kapcsolat is, akkor meglepö, hogy a környezet-egészségügy kérdése csak 2009 óta része a helyi programnak, és akkor sem vált kötelező tartalmi elemmé. ${ }^{24}$ Azzal,

${ }^{21}$ Kvt. 46.§ (1) bekezdés b) pontja. Ez egyben azt is jelenti, hogy helyi környezetpolitikájukat 1995 előtt az önkormányzatok nem fogalmazták meg. Ugyanakkor érdemes felhívni a figyelmet az 1990-es években önkormányzati feladatot és hatáskört szabályozó törvények rendelkezései, illetve a helyi környezetvédelmi program kötelező tartalmi elemei közötti átfedésre. Vö. 1990. évi LXV. tv. 8. §; 1991. évi XX. törvény 20-21.§; 1995. évi LIII. törvény 47.§ (1).

${ }^{22}$ Ebben 2009. január 1-e jelentős változást hozott.

${ }^{23}$ Kvt. 48/B. § és 48/E. §.

${ }^{24} \mathrm{Kvt} .48 / \mathrm{E}$. § (2),„Az (1) bekezdésben foglaltakon túl a települési környezetvédelmi program - a település adottságaival, sajátosságaival és gazdasági lehetöségeivel összhangban - tartalmazhatja a) a települési környezet minöségének, környezetbiztonságának, környezet-egészségügyi állapotának javítása, valamint a természeti értékek védelme és fenntartható használata érdekében különösen: aa) a területhasználattal, ab) a földtani képzödmények védelmével, ac) a talaj, illetve termöföld védelmével, ad) a felszini és felszín alatti vizek, vizbázisok védelmével, ae) a rekultivációval és rehabilitációval, af) a természet-és tájvédelemmel, ag) az épitett környezet védelmével, ah) az ár-és belvizgazdálkodással, ai) az üvegházhatású gázok kibocsátásának csökkentésével, az éghajlatváltozás várható helyi hatásaihoz való alkalmazkodással." 
hogy a környezetvédelmi törvény a helyi program választható tematikái között sorol fel számos olyan területet, mely a szakági törvények alapján a települési önkormányzatot helyi szabályok megalkotására kötelezi, ${ }^{25}$ azt a látszatot kelti, mintha azok a helyi szabályok nem tartoznának a helyi környezetpolitika körébe. Mintha azokat a helyi szabályokat nem úgy kellene mindig megalkotni, és a feladatokat meghatározni, - figyelembe véve a környezetpolitikai elveket - hogy azok javítsák a települési környezet minőségét, a környezetbiztonságot, a környezet-egészségügy állapotát, a természeti értékek védelmét, biztosítsák a fenntartható használatot.

A környezetvédelmi szabályozás azért is ellentmondásos, mert nincsen összhangban a nemzeti környezetvédelmi programokkal, melyek az önkormányzatok feladatait olyan területen is meghatározták, ahol a helyi programalkotás tetszöleges, vagy még úgy sem jelenik meg. ${ }^{26}$ A környezetvédelmi törvény a helyi környezeti programot szükíti $1 \mathrm{e}^{27}$ a „legalább” szófordulattal, miközben a törvény felhatalmazása alapján megszületett országgyülési határozatok az önkormányzati programot szélesebb körben határozzák meg. A helyi program megalkotása során - a környezetvédelmi törvény alapján - az önkormányzatnak a nemzeti környezetvédelmi programot figyelembe kell vennie. ${ }^{28}$ Mindebböl az

\footnotetext{
${ }^{25}$ Csak néhány a szakági törvényekböl, melyek az önkormányzatok számára feladatot, vagy jogalkotási kötelezettséget írnak elő: 1996. évi XXI. törvény a területfejlesztésről és a területrendezésröl; 2000. évi CXII. törvény a Balaton Kiemelt Üdülökörzet Területrendezési Tervének elfogadásáról és a Balatoni Területrendezési Szabályzat megállapításáról; 1997. évi LXXVIII. törvény az épített környezet alakításáról és védelméröl; 1993. évi XLVIII. törvény a bányászatról.

26 Vesd össze a helyi programra vonatkozó Kvt. rendelkezéseket a nemzeti környezetvédelmi programokkal. 83/1997. (IX. 26.) OGY határozat a Nemzeti Környezetvédelmi Programról (I. NKP); 132/2003. (XII.11.) OGY határozat a 20032008. közötti időszakra szóló Nemzeti Környezetvédelmi Programról (II. NKP), 96/2009. (XII. 9.) OGY határozat a 2009-2014. közötti időszakra szóló Nemzeti Környezetvédelmi Programról (III. NKP); 27/2015. (VI. 17.) OGY határozat a 2015-2020. közötti időszakra szóló Nemzeti Környezetvédelmi Programról (IV. NKP).

${ }^{27}$ A felsorolás egyszerre tekinthető szükítésnek és a program specifikus területeire vonatkozó szabályozásnak, ha figyelembe vesszük a 48/B. § (2) bekezdését is. Azonban szükítőnek tekintem, ha az önkormányzat feladatát más jogszabály tartalmazza, mert a „legalább,” a „különösen” vagy a felsorolás végén elhelyezendő „egyéb” szó nélkül a „tartalmaznia kell” fordulat taxatív felsorolásra utal. Ugyanez mondható el a választható felsorolásra is a „tartalmazhatja” fordulat kapcsán.

${ }^{28}$ Ktv. 49/A. § (2) bekezdés.
} 
következik, hogy a helyi környezetvédelmi programot, amennyiben az csak a kötelező tartalmi elemekre terjed ki, nem tekinthetjük a helyi környezetpolitika átfogó dokumentumának.

\subsection{A megközelités változása}

A nemzeti környezetvédelmi programok alapján az önkormányzati autonómia, a központi kormányzat és a helyi önkormányzat közötti viszony megítélése folyamatosan változott. ${ }^{29}$ $\mathrm{Az}$ I. NKP-t még az önkormányzati autonómiára tekintettel dolgozták ki, s ehhez igazodott a központi kormányzat feladata is. A program megvalósítási eszközeiről szóló 4 . fejezetben a program stratégiai alapelvei közé felvett „partneri viszony” egyértelmüen ezt tükrözi:

„A környezetpolitika kialakitása és megvalósitása során a Program partneri viszonyt kiván kialakitani a különbözö szereplökkel, és ezt a stratégia elvei is tükrözik. Ennek érdekében meg kell teremteni az egyes közigazgatási szintek közötti hatékony és folyamatos együttmüködés feltételeit. A 'szubszidiaritás' elvét követve egyre nagyobb szerep jut az önkormányzatoknak és társulásaiknak a környezeti problémák megoldásában. A központi kormányzat környezetpolitikájának e tevékenységeket kell elösegítenie és szolgálnia.

A II. NKP-ben az önkormányzatokkal kapcsolatosan még mindig találunk hivatkozást a szubszidiaritás elvére, azonban itt a partnerség már nem stratégiai alapelv, inkább a program tervezéséért és végrehajtásért felelősök és közremüködők magatartásával szembeni elvárásként ragadható meg.

„Az NKP-II az ország minden lakóját szolgáló program. A környezetpolitika megvalósitása a végrehajtásban érdekelt és abban közremüködö valamennyi szereplö összehangolt cselekvését igényli. Az NKP-II megvalósulásához elengedhetetlenül fontos az érdekeltek aktív közremüködése mind a tervezés folyamatában, mind a végrehajtás fázisában. Ez országos, regionális és helyi szinten is konstruktiv párbeszédet, a javaslatok érdemi mérlegelését,

29 A helyi környezetpolitika változása összhangban volt azokkal a változásokkal, melyek az önkormányzatok államhatalmi szerepének átértékelődése miatt következtek be. Részletesen lásd CsinK Lóránt: Mozaikok a hatalommegosztáshoz. Pázmány Press, Budapest, 2014, 155-171. 
figyelembevételét és érvényesitését teszi szükségessé. Ehhez meghatározott egyeztetési mechanizmusok kiépitésére és müködtetésére van szükség.

A közigazgatás feladata, hogy a kitüzött középtávú környezetpolitikát végrehajtsa a társadalom környezetvédelmi igényeinek és érdekeinek megfelelö módon. A jelen dokumentumban lefektetett környezetpolitikát össze kell hangolni a gazdasági és területfejlesztési elképzelésekkel. A szubszidiaritás elvének megfelelöen az önkormányzatokszerepét is erösiteni kell az NKP-II megvalósitásában. Az önkormányzatoknak - környezetvédelmi feladataik ellátásán túlmenöen - a regionális környezetvédelmi programok kidolgozásába és végrehajtásába is be kell kapcsolódniuk. ",30

A III. NKP szellemiségében már jelentős változás érzékelhető. Jelzés értékü, hogy a szubszidiaritás elvének említése már nem kötődik az önkormányzatokhoz.

„Jelen, harmadik Nemzeti Környezetvédelmi Program a 20092014 közötti idöszakra szól, de ennél hosszabb távra is kitekint. Az ország fenntartható fejlődési pályára való átállását kívánja sajátos eszközeivel elösegíteni. A környezeti szempontok és összefüggések megjelenitésével, a társadalmi és gazdasági lehetöségekkel összehangolt, szükséges intézkedések meghatározásával rendszerbe foglalja a környezet védelmére irányuló célokat és feladatokat. A tennivalóknak a társadalmi-gazdasági munkamegosztáshoz illeszkedő, a területi sajátosságokat és a különbözö társadalmi igényeket, szempontokat is figyelembe vevö megfogalmazásával a korábbinál nagyobb súlyt fektet az együttmüködésre, a decentralizáció és a szubszidiaritás elvére."

A jogalkotásról szóló megjegyzések is mutatják a megközelítés változását. A helyzetértékelésben az önkormányzati rendeletalkotással szemben megfogalmazott kritikák mellett pozitív értékelést kapott a központi szabályok megjelenése, melyek a környezetpolitika szempontjából az önkormányzati rendeletek kedvező irányú módosulását eredményezték. A jövőre nézve pedig a program a jogi szabályozási eszközök felülvizsgálatát tüzte ki célul az alábbiak szerint:

${ }^{30}$ II. NKP, 84. 
„Olyan jogi környezet kell teremteni, amelynek keretei között letisztult, a környezetügyi érdekeknek és az állampolgárok elvárásainak megfelelöen módosult hatósági jogkör alakul ki (túlszabályozás, illetve a szabályozás elaprózottságának megszüntetése, hatáskör-ésszerüsités). Ezzel összefüggö feladat az állami és önkormányzati feladatmegosztás jogi, szakmai alapon történö felülvizsgálata (a zöldhatósági jogkörböl pl. a kistérségek számára leadható feladat- és hatáskörök lehetöségének, okszerüségének vizsgálata, különösen a hulladékgazdálkodással, a levegötisztaság-védelemmel, valamint a zaj- és rezgésvédelemmel kapcsolatos ügyekre); az önkormányzati hatásköri feladatok áttekintése, szükség szerinti módositása (például a védelemre tervezett területekkel kapcsolatos hatáskörök, valamint az önkormányzati természetvédelmi örszolgálat szervezési, ellenörzési feladatai); a székhely-hatóságok és kirendeltségek közötti feladatmegosztás szabályozása. Mindezen vizsgálatok és a javaslatok megfogalmazása során kiemelt figyelmet kell forditani a feladatok és a rendelkezésre álló kapacitások összhangjának kialakitására, hatáskör telepités esetén a feladatellátáshoz szükséges költségvetési források biztositására."

A IV. NKP mintegy a folyamat lezárásaként mutatja az önkormányzati autonómia megszünését, és tükrözi az Alaptörvény önkormányzathoz való viszonyát. A programban már nincsen külön szó az állami és önkormányzati feladatmegosztásról, az önkormányzati és a központi jogalkotás viszonyáról. Az önkormányzatok már a partnerségi viszonyrendszerben sem kapnak kiemelt figyelmet.

„A Program megfelelö végrehajtása az egész társadalom részvételét igényli, melynek során a legszélesebb körü partnerség megvalósitása szükséges. Ebben a kormányzat aktív partnerei az önkormányzatok, a vállalkozások, a gazdálkodók, a tudományos, oktatási-nevelési, szakmai intézmények és civil szervezetek, valamint a lakosság. Az együttmüködés fontos eleme az országos, megyei és települési szintü feladatok összehangolása is annak érdekében, hogy az adott feladatok megoldása azon a szinten valósuljon meg, ahol az a leghatékonyabban biztositható és a megfelelö tudás és helyismeret rendelkezésre áll."

A fentieket összegezve megállapíthatjuk, hogy a helyi környezetpolitika kezdetekben az önkormányzati autonómiára 
épülve alakult ki, majd az autonómia folyamatos visszaszorításán keresztül jutottunk el oda, hogy az önkormányzatok szerepe a helyi környezetpolitika meghatározásában háttérbe szorult. Megjegyzendő, hogy a környezetpolitika meghatározásában az önkormányzati autonómia felszámolása egy folyamat eredménye, mely folyamatot nem az Alaptörvény elfogadása indította el, az a folyamatot és eredményét csak egyértelmüvé tette. ${ }^{31}$

\subsection{A helyi környezetpolitika és az önkormányzati rendeletalkotás}

A helyi környezetpolitikát ugyan önmagában nem az határozza meg, hogy adott kérdéskör a helyi környezetvédelmi programban megjelenik vagy sem, a politika végrehajtási eszközei részben mégis ezen múlnak. A környezetvédelmi törvény az önkormányzatot feladatainak végrehajtására, így a helyi program végrehajtására is, rendeletalkotási és határozathozatali joggal ruházta föl. ${ }^{32} \mathrm{~A}$ helyi környezetpolitika egészét magában foglaló helyi program rendelettel történő végrehajtására a környezetvédelmi törvény külön felhatalmazást nem ad. Így az önkormányzat környezetpolitikáját rendeletalkotással csak akkor tudja érvényesíteni, ha a jogalkotás alkotmányos feltételei - más törvény felhatalmazása alapján fennállnak.

Az Alaptörvény a helyi közügyek, illetve a helyi társadalmi viszonyok szabályozását teszi lehetővé az önkormányzatok számára, de ezzel a joggal törvényi keretek között élhet csak. Az önkormányzatok helyi környezetpolitikát szolgáló rendeletalkotásával kapcsolatos ellentmondások egészen korán jelentkeztek. ${ }^{33}$ A helyi rendeleteket jellemzően azzal támadták, hogy

31 A 37/1994. (VI. 24.) AB határozatára hivatkozva Csink utal arra, hogy az Alkotmánybíróság már a kezdetektől „az alapjogi modellt a közigazgatási szervezeti egység szemlélethez közelitette." Ezért szerinte az Alaptörvény és a felhatalmazása alapján megszületett önkormányzati törvény az Alkotmánybíróság gyakorlatának folytatása. CSINK: i.m., 164.

${ }^{32}$ Kvt. 46.§ (1) bekezdés c) pontja.

${ }^{33}$ Fodor több munkájában is részletesen tárgyalja az önkormányzatok környezeti tárgyú rendeletalkotási jogának alkotmányos kereteit. Lásd: FODOR László: Környezetvédelem az Alkotmányban. Gondolat - Debreceni Egyetem, Állam- és Jogtudományi Kar, Budapest, 2006; FODOR László A helyi szabályok eltérése a központi elöírásoktól - környezetvédelmi megfontolások. Jogtudományi Közlöny 
az önkormányzatok a rendelet megalkotására nem rendelkeztek hatáskörrel, vagy túllépték a törvényi felhatalmazást. A jogforrási hierarchiába ütköző rendeletek esetén az Alkotmánybíróság többnyire nem foglalt állást abban a kérdésben, hogy vajon az önkormányzat által megfogalmazott szabályok egyébként megfeleltek volna-e az alkotmányos követelményeknek. Ez alól némileg kivételt képeznek az 1994-ben, a szemétszállítási díjjal kapcsolatban hozott határozatok. ${ }^{34} \mathrm{~A}$ határozatok alapján az állapítható meg, hogy az Alkotmánybíróság nem a szemétszállítás szabályozásának tartalmát kifogásolta, hanem csak azt, hogy a helyi önkormányzat olyan jogviszonyt szabályozott, melyet a Polgári Törvénykönyv hatálya alá tartozása miatt csak törvény vagy kormányrendelet rendezhet. A jogforrási hierarchiába az önkormányzati rendelet azért ütközött, mert az Alkotmánybíróság a jogviszonyt polgári jogi szerződésnek minősítette, nem közjogi jellegü kapcsolatnak. A települési hulladékkezelési közszolgáltatás szabályozását évtizedekre meghatározta ez a döntés. Évekig tartott, míg az Alkotmánybíróság gyakorlatán keresztül sikerült egyértelmüvé tenni, hogy a szolgáltatás-ellenszolgáltatás polgári jogi elve nem zárja ki a közszolgáltatási szerződésnek a környezet védelmét szolgáló közjogi jellegü korlátozását, ${ }^{35}$ de a közjogi elem elfogadottsága máig problémát okoz. ${ }^{36}$

Mindez felhívja a figyelmet arra, hogy az önkormányzati rendeletalkotás joga nemcsak attól függ, hogy arra mely törvény és

2016/7-8., 353-364. A hulladékkezeléssel, vízszolgáltatással kapcsolatos AB határozatok elemzését ld. PUMP: i.m.

${ }^{34}$ 25/994. (V. 10.) AB határozat, 39/1994. (VI. 30.) AB határozat, 40/1994. (VI. 30.) $\mathrm{AB}$ határozat, 41/1994. (VI. 30.) AB határozat, 43/1994. (VI. 30.) AB határozat.

${ }^{35}$ A jogi fogalmak tudományos tartalmának meghatározása kapcsán Jakab fontosnak tartja, hogy az ne szakadjon el a joggyakorlattól, és a tudomány a releváns jogi aktorok által elfogadott tartalmat tekintse kiindulópontnak, ami az aktorok értelmezési gyakorlatán keresztül ragadható meg. Nem zárja ki ugyanakkor annak lehetőségét, hogy a releváns aktorok ,mindannyian 'hibásan' hiszik egy fogalom tartalmáról, hogy az ' $x$ ' (noha valójában ' $y$ ')." S megállapítja, hogy ez (a communis error facit jus) az uralkodó vélemény azonban megtámadható. JAKAB András: Az európai alkotmányjog nyelve. Nemzeti Közszolgálati Egyetem, Budapest, 2016, 74-75. Véleményem szerint ennek példájaként értékelhető az $\mathrm{AB}$ gyakorlatában a szerződéses elemek értékelésében való elmozdulás.

${ }^{36}$ A hulladékkezelési közszolgáltatásokkal kapcsolatban az ombudsmani hivatalhoz érkező panaszok többsége továbbra is a közjogi elemet - a szerződés kötelező igénybevételét, és az ehhez kapcsolódó díjfizetési kötelezettséget - kérdőjelezi meg. 
milyen felhatalmazást ad, hanem azon is múlik, hogy a rendelet alkotmányosságának felülvizsgálatát végző szerv milyen elméleti alapokon ítéli azt meg, illetve a környezetpolitika végrehajtását szolgáló egyes jogintézmények elméleti alapjai mennyiben tisztázottak. A kérdés jelentőségét húzza alá az a tény, hogy a környezetpolitika terén olyan új jogintézmények jelennek meg, melyek jogi - különösen elméleti - megítélése hiányzik. ${ }^{37}$

\section{4 Önkormányzati eszközök a helyi környezetpolitika alakitásában}

A helyi környezetpolitika alakításában az önkormányzati rendeletek fontos szerepet töltenek be. Az önkormányzati rendeletek a helyi viszonyok szabályozásán keresztül fogalmazzák meg a helyi közösség társadalmi elvárását a helyi közösség tagjai számára, ${ }^{38}$ illetve kifelé is, védve a helyi közösség társadalmi, gazdasági fejlődésének irányát, ${ }^{39}$ teremtik meg helyi szinten a

${ }^{37} \mathrm{Az}$ új jogintézmények elméleti tisztázatlansága miatti gyakorlati problémákra hívtam fel a figyelmet hulladékkezelési közszolgáltatással foglalkozó cikkemben. PUMP Judit: Jogági gubancok a közérdek érvényesítésében. Közjavak, MTA-DE Közszolgáltatási Kutatócsoport, II. évf. 3. sz. 2016. július-szeptember.

${ }^{38}$ A Kúria önkormányzati tanácsa elé kerülö ügyek jól mutatják, hogy milyen színes a helyi jogalkotás. (Például a Kúria önkormányzati tanácsának Köf.5010/2016/4. számú és Köf.5011/2016/4. számú határozata.) Megjegyzendő ugyanakkor, hogy a helyi közösség együttélési szabályainak jogszabályba foglalása azt mutatja, hogy hiányoznak azok a feltételek, melyek alapján az együttélés szabályai jogalkotás nélkül megfogalmazhatók és kikényszeríthetők. (Jól ismert hazánkban, hogy a többségében német lakosú településeken az utcákat a lakosok nem azért tartották tisztán, és ápoltan, mert azt jogszabály elöírta, hanem azért, mert a közösség íratlan társadalmi elvárását mindenki elfogadta, tiszteletben tartotta, és kikényszerítésében a közösség tagjaként részt vett.)

39 A Salföldi önkormányzat rendeletében korlátozta a bányászati tevékenységet, biztosítva ezzel természeti környezetének védelmét, a helyi közösség megélhetésének alapját. Törvényességi kontrolljára lásd a Kúria önkormányzati tanácsa Köf.5.003/2014/4. számú határozatát. Ebbe a körbe tartozónak tekintem, pl. a turizmus okozta többlet költségek fedezetét szolgáló idegenforgalmi adóra vonatkozó rendeletet is. Hegykő község rendelete kapcsán mondta ki a bíróság, hogy az idegenforgalmi adó célja kettős: „részben annak garantálása, hogy a nem állandó lakos vendég maga is járuljon hozzá az általa igénybe vett vagy igénybe veendö kommunális szolgáltatások és a helyi közszolgáltatások költségeihez. Másrészt viszont az idegenforgalmi adó tételezett célja az, hogy a megnövekedett turizmus okozta esetleges negativ környezeti externáliák költségeit az önkormányzat az adó alanyaira, a nem állandó lakos vendégekre terhelje." Lásd a Kúria önkormányzati tanácsa Köf.5017/2016/5. számú határozatát. 
környezethasználók és a teherviselők érdekei közötti egyensúlyt. ${ }^{40}$ $\mathrm{Az}$ önkormányzatok környezetpolitikai eszközei sokszínüek, és gyakran más politikák érvényesítésében is segítséget nyújtanak. ${ }^{41} \mathrm{~A}$ politika végrehajtásában a jogi és nem jogi eszközöknek egyaránt szerepe van és lehet. Ezekre való utalást a nemzeti környezetvédelmi programok tartalmaznak. Azonban a helyi környezetpolitika alakításában nem mindig az önkormányzat döntése a meghatározó. Az alkotmányos védelem nem terjed ki arra, hogy az önkormányzat milyen területen és milyen eszközökkel befolyásolhatja a helyi környezetpolitikát, hiszen az nem szakítható el a központi környezetpolitikától és céljaitól, eszközeitől.

A nemzeti környezetvédelmi programokból kiolvasható, hogy egyes területeken az önkormányzat szerepe, illetve döntéshozatali lehetősége szinte teljesen megszünt, ${ }^{42}$ míg más területeken alig van változás. $^{43} \mathrm{Az}$ önkormányzat helyi környezetpolitikában betöltött szerepe nem szakítható el az országban zajló, különösen a környezet védelmét érintő folyamatoktól. ${ }^{44} \mathrm{Az}$ jól látható, hogy ezen a területen is felváltja az alapjogi modellt - mely a helyi közösségekre bízza a helyi szabályok megalkotását - a közigazgatási szemlélet érvényesítése, melynek következtében a helyi szintü normákat is egyre inkább központi szabályok határozzák meg. ${ }^{45}$ A környezetvédelem területén ez akár indokolható is, ha a központi szabályozás célja a magas szintü védelem elérése mindenhol. A kérdés azonban, hogy a hazai változtatások valóban igazolhatóak-e ezzel a céllal minden esetben, illetve milyen szempontok mentén és

40 A helyi zajszabályozás tipikusan olyan terület, ahol az önkormányzat a környezethasználó magatartásának szabályozásán keresztül kívánja védeni a teherviselők érdekeit. Lásd a Kúria önkormányzati tanácsa Köf.5050/2015/4. számú határozatát.

41 A témával kapcsolatos részletes elemzést lásd PUMP Judit: Hulladékkezelési közszolgáltatások szervezése. In: HORVÁTH M. Tamás-BARTHA Ildikó (szerk.) Közszolgáltatások megszervezése és politikái. Merre tartanak? Dialóg Campus, 2016, Budapest-Pécs, 159-171.

${ }^{42}$ A IV. NKP-ban a tematikus stratégiák között tárgyalt hulladékgazdálkodás (3.4. pont) céljainak elérésében még a háztartási hulladék kapcsán sem említik meg az önkormányzatot, mintegy figyelmen kívül hagyva annak törvényi feladatait.

${ }^{43}$ Vesd össze a négy nemzeti környezetvédelmi programot.

${ }^{44}$ „Azáltal, hogy az Alaptörvény a közigazgatás szervezeti egységeiként gondol a helyi önkormányzatokra és az államigazgatási hatásköröket helyezi elötérbe, a helyi önkormányzatokat a végrehajtó hatalomhoz közelíti." CSINK: i.m., 171.

${ }^{45}$ CSINK: i.m., 160-161. 
kiknek a részvételével születnek meg azok a döntések, melyek az önkormányzati szerepet és eszközt az egyes területeken megváltoztatják.

\section{A helyi környezetpolitika jogi és igazgatási rendszere}

A helyi környezetpolitika jogi szabályozásában bekövetkező változások nem hagyták érintetlenül az igazgatási rendszert sem. Amikor a helyi jogalkotás helyébe a központi szabályozás lép, akkor az azt is jelenti, hogy az önkormányzati hatósági szervezetrendszer helyett a jogszabályok kikényszerítését az államigazgatás hatóságai veszik át, még akkor is, ha személyében ez a települési önkormányzat polgármesterét, vagy jegyzőjét érinti. ${ }^{46} \mathrm{Ez}$ azt is jelenti, hogy a helyi környezetpolitika érvényesítése függ attól, hogy milyen a helyi környezetpolitika kikényszerítését végző államigazgatás rendszere.

A környezetvédelem államigazgatási rendszerének - ideértve az igazgatási és hatósági feladatokat ellátó, valamint a környezetpolitikai döntéseket megalapozó háttérintézményeket átalakítása 1989 óta folyamatosan zajlik, és mára odajutott, hogy sem minisztériumi, sem regionális államigazgatási szinten nincsen olyan önálló szervezet, melynek rendeltetése a környezeti érdekek horizontális védelme lenne. A helyi környezetpolitikai célok érvényesítése szempontjából ennek egyrészt azért van jelentősége, mert nem egyértelmü, hogy a központi kormányzati szinten adott környezeti ügy - részben fogalmának tisztázatlansága miatt ${ }^{47}-$ mely

\footnotetext{
${ }^{46}$ A Kúria egy zajjal kapcsolatos beadvány kapcsán rámutatott, hogy a Kormány a Kvt. felhatalmazása alapján a települési önkormányzat polgármesterének és jegyzöjének környezetvédelmi államigazgatási hatáskörét államigazgatási hatósági ügyekben határozhatja meg, míg a Kvt. önkormányzati rendelalkotásra vonatkozó felhatalmazása önkormányzati hatósági ügyekre vonatkozik. Kúria önkormányzati tanácsa Köf.5050/2015/4. számú határozata [24].

${ }^{47}$ A környezetvédelmi és természetvédelmi felügyelöségek integrációjával, valamint a környezetvédelmi ügy fogalmának tisztázatlanságával kapcsolatos problémákkal is foglalkozott a Magyar Közigazgatási Bírák Egyesülete és az Alapvető Jogok Biztosának Hivatala által szervezett, Társadalmi részvétel a környezetvédelmi ügyekben és annak uniós és hazai jogvédelme címü konferencia, illetve az elméleti és gyakorlati kérdések az ahhoz kapcsolódó tanulmánykötetben is megjelentek. Fodor László-Pump Judit (szerk.): Társadalmi részvétel a környezetvédelmi ügyekben. A részvételi jogok uniós és hazai jogi védelme. AJBH, Budapest, 2016.
} 
államigazgatási szervhez tartozik, másrészt, azért, mert a helyi érdekek nem feltétlenül esnek egybe a központi államigazgatási érdekekkel. ${ }^{48}$

A helyi és a központi érdekek közötti konfliktus rendezése szempontjából szükséges felhívni a figyelmet az önkormányzatok tevékenységének és rendeleteinek felülvizsgálatában bekövetkezett változásokra is. Az alkotmányos keretek lehetőséget adnak arra, hogy az önkormányzattól törvényalkotáson keresztül az államigazgatáshoz kerüljenek olyan területek, melyek a nemzeti környezetpolitikai célok megvalósítását szolgálják. Arra is lehetőség van, hogy a központi kormányzat a központi környezetpolitikai célokkal ellentétes önkormányzati rendeletek megsemmisitését kezdeményezze, alkotmányossági illetve törvényességi felülvizsgálatot kérve az Alkotmánybíróságtól, vagy a fővárosi, megyei kormányhivatalon keresztül a Kúriától, ${ }^{49}$ sőt, az önkormányzat mulasztása esetén az önkormányzati rendeletet megfelelö eljárási garanciák tiszteletben tartása mellett - a kormányhivatal vezetője maga pótolja. ${ }^{50} \mathrm{Az}$ önkormányzatok számára azonban ilyen lehetőségek nincsenek. Az önkormányzatnak

\footnotetext{
${ }^{48}$ Példaként egy stratégiai környezeti vizsgálatból idézünk: „A konfliktus forró pontja lehet a 2001 óta húzódó, komoly lakossági és környezetvédelmi ellenállást kiváltó, és jogilag teljesen megnyugtatóan le nem zárt toronyi lignitbánya-ügy. Ez a terv, miszerint egy felszini bányát nyitnának Szombathelytöl alig $10 \mathrm{~km}-\mathrm{re}$, nyugatra - egy alvó, de a veszélyt magában hordozó ügy. Bár a települések saját rendezési terveikkel, és a megye a rendezési tervével igyekeztek megakadályozni a bányászat megindítását (már a kutatások megkezdését is ellehetetlenitve), mind a kormány kommunikációja, mind országos stratégiai-tervezési dokumentumok, mint pl. a Nemzeti Energiastratégia 2030 komoly szinten épitenek a hazai lignitvagyon felhasználására." BFH Európa Projektfejlesztő és Tanácsadó Kft.: Vas Megye Gazdaságfejlesztési Fókuszú Stratégiai Programjának Stratégiai Környezeti Vizsgálata, Szombathely, 2014. szeptember 22., 34.

49 GYERGYÁK Ferenc: Önkormányzati rendeletek törvényességi felügyelete 20122014. Új magyar közigazgatás, 2016/1, 49-63.

50 A Gyergyák által hivatkozott, a kormánymegbízott által pótolt önkormányzati rendeletek közül a a Pest Megyei Kormányhivatal vezetője által a vízfolyások menti parti sáv kijelölését pótló, a helyi építési szabályzat módosítását eredményező csömöri önkormányzati rendelet esik a helyi környezetpolitika körébe. Csömör Nagyközség Önkormányzata Képviselö-testületének 3/2014. (I. 31.) önkormányzati rendelete Csömör Nagyközség Helyi Építési Szabályzatáról szóló 12/2002. (IX. 19.) önkormányzati rendelet módosításáról megjelent a Magyar Közlöny 2014. 13. számában, 1897-1901. Az önkormányzat rendeletalkotási mulasztását a Kúria a Köm.5.069/2012/3 számú határozatában állapította meg, és a kormánymegbízottat a Köm.5025/2013/7 számú határozatával hatalmazta fel.
} 
nincs lehetősége arra, hogy alkotmányos szempontból vitassa, hogy adott környezeti ügyet törvénnyel miért vontak el töle, mert az elvonás nem közvetlenül a feladat elvonását jelenti, hanem a feladat ellátásának eszközeit érinti. Az Alaptörvény szerint a helyi önkormányzatokra vonatkozó szabályokat sarkalatos törvényben kell meghozni. ${ }^{51} \mathrm{Az}$ önkormányzati törvény az önkormányzat feladatait és hatáskörét úgy határozza meg, hogy közben az azok ellátásához szükséges eszközöket nem rendeli hozzá. Ebből következően sem az Alaptörvény, sem az önkormányzati törvény nem nyújt alapot az önkormányzatnak arra, hogy alkotmányos szempontból vitassa, ha egy feladata végrehajtását szolgáló eszköz használatát - ideértve az önkormányzati rendeletalkotást is - törvény, vagy törvény felhatalmazása alapján kormányrendelet megváltoztatja. A sarkalatosság csak arra nyújt garanciát, hogy az önkormányzati feladat- és hatáskör felsorolását módosítani csak az országgyülés kétharmada tudja.

A helyi környezetpolitika érvényesítése szempontjából az is jelentős változás, hogy az Alkotmánybíróság előtt utólagos normakontrollt már nem kezdeményezhet bárki, megszünt az actio popularis. Ez azt is jelenti, hogy sem a lakosság, illetve szervezetei, sem az önkormányzatok, illetve társulásaik nem fordulhatnak közvetlenül az Alkotmánybírósághoz, akkor sem, ha úgy érzik, hogy a helyi (regionális) környezetpolitika érvényesítését szolgáló önkormányzati eszközt felváltó központi jogszabály sérti az egészséges környezethez, illetve a testi és lelki egészséghez való jogot, vagy a helyi viszonyokra tekintettel a visszalépés tilalmába ütközik. ${ }^{52}$ A kérdés újragondolása jogosan vetődne fel a környezetpolitika kapcsán, különös tekintettel arra, hogy jelentős mértékben megváltoztak - véleményem szerint részben romlottak, részben megszüntek - az egészséges környezethez való jog védelmét szolgáló tartalmi, eljárási és szervezeti garanciák. ${ }^{53}$

\footnotetext{
${ }^{51}$ Alaptörvény 31. cikk (3) bekezdés.

${ }^{52}$ Alaptörvény XX. XXI. és P) cikkei.

${ }^{53}$ Kukorelli István volt alkotmánybíró az actio popularis megszüntetése kapcsán megállapítja, hogy más alkotmányokkal való összehasonlításban mind a korábbi széles, mind az új szükre szabott kezdeményezés ritka. Ezért felveti a kezdeményezők körének bővítését. KUKORELLI István: Magyarországot saját alkotmánya nélkül kormányozni nem lehet - a közjogász almanachja. Méry Ratio, 2014, 224. Ennek kapcsán érdemes megjegyezni, hogy van már arra példa, hogy az önkormányzatok érdekeik védelmét megpróbálták közvetlenül érvényesíteni az Alkotmánybíróság előtt.
} 


\section{A helyi környezetpolitika létrehozásának és végrehajtásának módja, stílusa}

\subsection{Az önkormányzat döntéshozatalának szabadságfoka}

A helyi környezetpolitika kialakítása és végrehajtása jelentős mértékben függ attól, hogy hogyan változik e körben az önkormányzat szerepe és felelössége. A fentiek során már bemutattuk, hogy az önkormányzat nem tud hosszú távú környezetpolitikát kialakítani, mert folyamatosan változik a környezetpolitika tartalma, középtávon sem látható elöre, hogy milyen lesz az állami és önkormányzati feladatmegosztás az egyes területeken, $\mathrm{s}$ az miben és hogyan érinti az önkormányzat döntéshozatali szabadságát. Az önkormányzati döntéshozatal változását jól láthatóvá teszi, ha egy koordináta rendszerben helyezzük el a döntést, az egyik tengelyen jelezve, hogy milyen kérdésekben dönthet, a másikon pedig döntésének szabadságfokát. A környezetpolitikai döntések szabadságfokát hatos skálán értékelhetjük: 1. teljes a szabadság, 2. jogszabályi korlátozás példálódzó felsorolással, 3. jogszabályi felsorolás - minimum szabályozással, 4. jogszabályi korlátozás - taxatív felsorolással, 5. külső, állami szereplő jóváhagyása, 6 . a szabadság hiánya.

Az alábbi ábra a települési hulladékkezelési közszolgáltatás kapcsán mutatja be, hogy milyen volt az önkormányzati döntéshozatal, amikor a rendszer az önkormányzati autonómiára épülve alakult ki, és hogyan változott meg akkor, amikor a közigazgatási szemlélet vált uralkodóvá. Az ábra 9 kérdéskört tartalmaz, egymás mellett tüntetve fel a két döntéshozatalt. A 2016os évszám jelzi a közigazgatási szemléleten alapuló rendszerhez tartozást.

A $100 \%$-os önkormányzati társulás - az Észak-kelet Pest és Nógrád Megyei Regionális Hulladékgazdálkodási és Környezetvédelmi Önkormányzati Társulás tulajdonában álló Zöld Híd Kft. fordult az Alkotmánybírósághoz alkotmányjogi panasszal. Az Alkotmánybíróság, bár a panaszt befogadta, megállapította, hogy az abban megfogalmazott sérelmek nem a Kft., hanem az érintett önkormányzatok sérelmei, ezért a panaszt elutasította. 3137/204. (IV. 24.) AB végzés. 
1. Ábra - az önkormányzati döntéshozatal szabadságának változása a hulladékos közszolgáltatásban

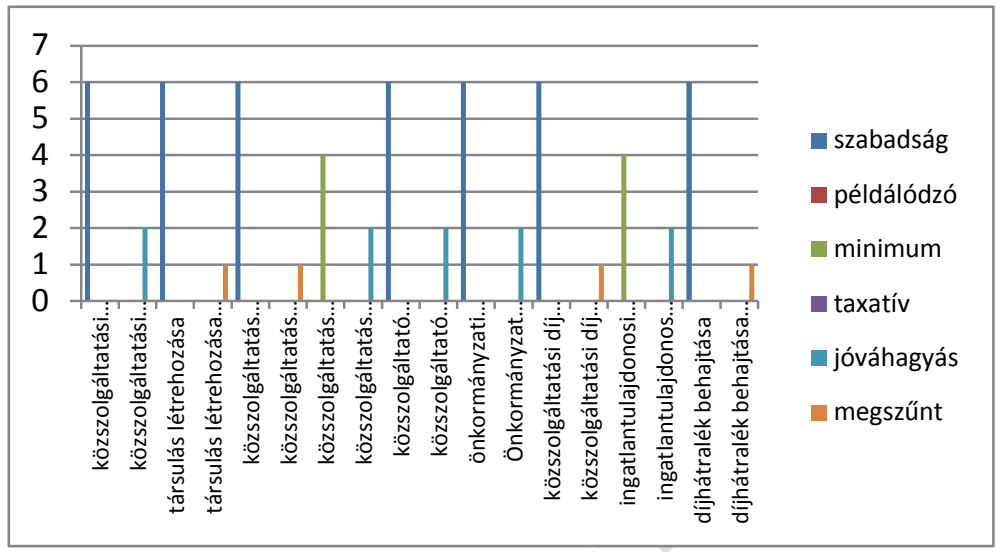

Forrás: saját szerkesztés

Ahogy az ábrából is látható, az önkormányzat szabadsága több esetben is megszünt, illetve döntése jóváhagyáshoz kötötté vált, ami azt jelenti, hogy a feladatokat egyrészt az állam átvette, másrészt új állami feladatok jelentek meg. Az önkormányzat és az állam közötti feladatmegosztás radikális változása azonban nemcsak az ő kapcsolatrendszerüket módosította, hanem mindenkiét, aki a közszolgáltatás nyújtásában, igénybevételében, ellenörzésében érintett volt és érintett lett. Azt sem felejthetjük el, hogy a kapcsolatrendszerek megváltozása magával hozza a jogok és kötelezettségek, valamint a felelösség érvényesítési rendjének módosulását.

\subsection{Felkészülési idő a helyi környezetpolitikát érintő változásokra}

A fentiek miatt felvetendő kérdésnek tartjuk, hogy vajon a helyi környezetpolitika kialakításában, végrehajtásában érintett szereplők hogyan tudnak alkalmazkodni az új viszonyokhoz. Ha ez a jogszabályok megváltozásával jár, akkor mennyi idő áll rendelkezésükre a felkészülésre, az új szabályokhoz, feltételekhez való igazodásra. Az Alkotmánybíróság értelmezésében a megfelelő 
felkészülési idő biztosítása jogállami követelmény. ${ }^{54}$ A felkészülési idő megfelelősségének vizsgálatára az Alkotmánybíróság tesztet állított fel. Eszerint vizsgálni kell, hogy a jogszabály kihirdetése és hatályba lépése között eltelt idő kellő mértékü-e 1. a jogszabály szövegének megszerzésére, és áttanulmányozására; $2 . \quad$ a jogalkalmazó szervek számára a jogszabály alkalmazására való felkészüléshez; 3. a jogszabállyal érintett személyek és szervek számára annak eldöntéséhez, hogy miként alkalmazkodjanak a jogszabály rendelkezéseihez az önkéntes jogkövetés személyi és tárgyi feltételeiről való gondoskodáshoz. ${ }^{55}$ Az Alkotmánybíróság a kellő felkészülési idő biztosítását a jogszabály címzettjei szempontjából tartja értékelendőnek, függetlenül attól, hogy azok a jogszabály végrehajtásáért felelős szervek, vagy olyanok, akikre a jogszabály kötelezettséget ró. A megfelelő felkészülési idő biztosítása teszi lehetővé az önkéntes jogkövetést.

A kellő idő hiánya önmagában még nem vezet alaptörvényellenességhez. Az Alkotmánybíróság esetről esetre vizsgálja meglétét, s figyelembe veszi mindazokat a tényezőket, érveket, melyek indokolhatják a rendelkezésre álló felkészülési idő rövidségét, illetve hiányát. „Az alkotmányellenesség csak a jogszabály alkalmazására való felkészülést szolgáló idötartam kirivó, a jogbiztonságot súlyosan veszélyeztetö vagy sértö elmaradása, illetöleg hiánya esetén állapítható meg. ${ }^{56}$

A jogszabály alkalmazására való felkészülési idö kirivó hiánya... alaptörvény-ellenességhez vezet. A jogbiztonságot súlyosan sérti, ha az új, illetve többletkötelezettségeket elöiró jogszabályi rendelkezés kihirdetése és hatályba lépése közötti felkészülési idö elmarad vagy olyan rövid, hogy nyilvánvaló, hogy a jogszabály címzettjei jóhiszemüségük, legjobb szándékuk és igyekezetük ellenére sem vagy csak rendkívüli eröfeszitések árán - tudnának kötelezettségeiknek eleget tenni. Ellentétes a jogállamiság elvével, ha a kellö felkészülési idö hiányából eredöen a jogszabály címzettjei a megváltozott rendelkezéshez való alkalmazkodás rendkivüli nehézsége miatt nyilvánvalóan, illetve az új szabályozás

\footnotetext{
${ }^{54}$ Alkotmány 2. § (1), Alaptörvény B) cikk (1) bekezdés.

${ }^{55}$ Az Alkotmánybíróság a felkészülési idő vizsgálatának tesztjét a 28/1992. (IV. 30) $\mathrm{AB}$ határozatában fogalmazta meg, $\mathrm{s}$ annak alkalmazandóságát a 6/2013. (III. 1.) $\mathrm{AB}$ határozat megerösítette.

56 7/1992. (I. 30.) AB határozat, ABH 1992, 45, 47.
} 
megismerhetöségének hiányában valószinüsithetöen jogsértö helyzetbe kerülnek; különösen, ha emiatt joghátrányok is érik (érhetik) öket." "57

Az önkormányzat és az állam közötti feladatmegosztás változása gyakran azzal jár, hogy olyan központi jogszabályok születnek, melyek egyszerre keletkeztetnek az önkormányzatok számára jogalkotási kötelezettséget, helyeznek át ügyet önkormányzati hatósági jogkörből államigazgatási hatósági jogkörbe, és iktatnak be a rendszerbe új szereplőket, hoznak létre új államigazgatási feladatokat és hatásköröket. ${ }^{58} \mathrm{Az}$ sem példa nélküli, hogy a helyi környezetpolitika érvényesítése szempontjából fontos helyi szabályok alkalmazásának körét törvény rövid időn belül többször is módosítja, hol enyhítve, hol szigorítva a törvényi szabályozáson. ${ }^{59} \mathrm{E}$ kiszámíthatatlan és ad hoc jellegü változtatások mögött gyakran az érintettekkel való utólagos egyeztetés húzódik meg, ami mutatja, hogy a jogszabály nem volt kellőképpen elökészítve. Az Alkotmánybíróság gyakorlata szerint a társadalmi egyeztetés elmaradása a törvénytervezet elökészítése során nem eredményezi a törvény közjogi érvénytelenségét. ${ }^{60}$ Ugyanakkor a társadalmi egyeztetés hiánya miatt módosuló jogszabályokhoz az érintettek nem tudnak kellöképpen igazodni. A felkészülési idő hiánya ugyanis ebben az esetben nem csak abban ragadható meg, hogy a kihirdetett jogszabály rendelkezéseihez való alkalmazkodásra a hatályba lépés előtt az érintettek nem tudnak felkészülni, hanem abban is, hogy a jogalkotó nem szánt elég időt a jogszabály elkészítésére, és a nem kellő mértékü társadalmi egyeztetés, vagy annak hiánya miatt olyan

\footnotetext{
${ }^{57}$ 6/2013. (III. 1.) AB határozat [239].

${ }^{58}$ Ez jellemezte, pl. a települési hulladékkezelési közszolgáltatás jogi szabályozásának átalakítását.

${ }^{59}$ Az önkormányzati rendelettel elfogadott helyi építési szabályzat kötelezően figyelembe veendő szabályait a jogalkotó az építési törvény módosításával (1997. évi LXXVIII. tv. 13. (2) bekezdése) több ízben is módosította. A 2015. évi CCXII. törvényt, mely minimálisra szükítette le azokat a helyi építési szabályokat, melyeket a legfeljebb 300 négyzetméter összes hasznos alapterületủ új lakások módosítása esetén kellett figyelembe venni, 2015. december 16-án hirdette ki, a törvény 2016. január 1én lépett hatályba. A szükítést a szakmai szervezetek tiltakozására és az egyeztetések eredményeként módosította. A módosító 2016. évi XXXVI. törvényt 2016. május 5-én hirdették ki, és az nyolc nap múlva lépett hatályba. Szintén a helyi építési szabályzatot érintette a 2016. évi CLXXIII. törvény, melyet 2016. december 19-én hirdettek ki, és 2017. január 1-én lépett hatályba.

${ }^{60}$ 165/2011. (XII. 20.) AB határozat, 20/2014. (VII. 3.) AB határozat.
} 
jogszabályt alkotott, mely rövid időn belül módosításra szorul. Szükséges arra is felhívni a figyelmet, hogy az olyan jogszabály, amely az önkormányzati rendelet rendelkezéseinek figyelmen kívül hagyását úgy teszi lehetővé, hogy közben a helyi szabály helyébe lépő központi jogszabály még nem született meg, vagy az önkormányzatnak nincs kellő ideje arra, hogy a módosításra tekintettel saját rendeletét az új helyzethez igazítsa, szintén jogbizonytalansághoz vezet. Ebben az esetben a felkészülési idő hiánya, vagy rövidsége a jogalkotásra kötelezett jogalkotó szempontjából értékelendő.

\subsection{A helyi érdekek érvényesitésének lehetösége}

A helyi lakosság érdekeinek érvényesítése is változik a döntéshozatal szintjétől függően. A helyi környezetpolitika célját, hogy a helyi környezethasználók és a teherviselők érdekei között egyensúlyt hozzon létre, más eszközökkel lehet elérni, ha a döntést az önkormányzat hozhatja meg, vagy ha az állami kompetenciába tartozik. Az állami hatáskörbe tartozó döntések esetén a lakosság érdekérvényesítésének színtere az államigazgatási eljárásokra tevődik át, ami többnyire azzal is jár, hogy az eljárások színhelye a helyi település helyett a megyeszékhely. Ehelyütt nem kívánjuk számba venni a különbségeket, amik azzal járnak, hogy a lakosnak hol és milyen eljárásban kell érdekeit érvényesíteni, csupán arra kívánjuk felhívni a figyelmet, hogy a helyi környezet állapotáról, a környezetterhelés mértékéröl és annak hatásáról csak a helyszinen lehet valós információt szerezni.

A helyi környezetpolitika fogalmának meghatározásakor kitértünk arra, hogy a lakosság a környezethasználó müködését eltérően ítéli meg a lakosok közötti érdekkonfliktusok mögött, az élet, az egészség veszélyeztettségének más szempontú megítélése miatt. Az érdekek egyeztetésének ezért fontos fóruma a környezethasználó tevékenységének engedélyeztetési eljárása, különösen a környezeti hatásvizsgálati eljárás, hiszen ez az eljárás hivatott megítélni azt, hogy vajon a helyi viszonyok között megengedhető-e a tervezett beruházás, tevékenység végzése, és ha igen, akkor milyen feltételek betartása mellett. A helyi érdekkonfliktusok feloldását lehetetlenítik el azok a kormányrendeletek, melyek a kiemelt beruházások esetén 
fellebbezésre tekintett nélkül végrehajthatónak nyilvánítják az első fokú hatósági határozatot. ${ }^{61}$ Ahogy hasonlóan negatív hatással van a helyi érdekkonfliktusok megoldására az, ha a kiemelt beruházások miatt olyan elsőfokú hatósági határozatok végrehajtását engedik meg a fellebbezés ellenére, melyek következtében a környezet állapotában visszafordíthatatlan változások következnek be.

\section{Zárógondolatok}

A fentiek alapján talán nem meglepő, ha azt a következtetést vonjuk le, hogy hiányoznak azok a feltételek, melyek alapján olyan hosszú távú, de akár középtávú, helyi környezetpolitikát lehetne megfogalmazni, melynek megvalósítása és végrehajtása kiszámíthatóan biztosítható lenne. Az önkormányzat és az állam közötti feladatmegosztás állandó változása, a helyi környezetpolitika tartalmának, eszközeinek folyamatos módosulása, a jogi feltételek és igazgatási rendszerek átalakulása nem segítik a helyi érdekkonfliktusok megoldását. A tanulmányban több esetben is jeleztük, hogy a gyakorlatban számos olyan kérdés merül fel, melyek tudományos vizsgálatára szükség lenne ahhoz, hogy e változó világban a helyi környezetpolitika megalkotását a helyi érintettek szükségesnek és végrehajthatónak érezzék és célja elérhető legyen.

${ }^{61}$ Kiemelt beruházások esetén a nemzetgazdasági szempontból kiemelt jelentőségű beruházások megvalósításának gyorsításáról és egyszerüsítéséről szóló 2006. évi LIII. törvény 12 . $\S(5)$ bekezdés $e$ ) pontja hatalmazza fel a kormányt, hogy a Ket.-től és az ügyfajtára vonatkozó különös eljárási szabályoktól eltérő rendelkezéseket hozzon. 


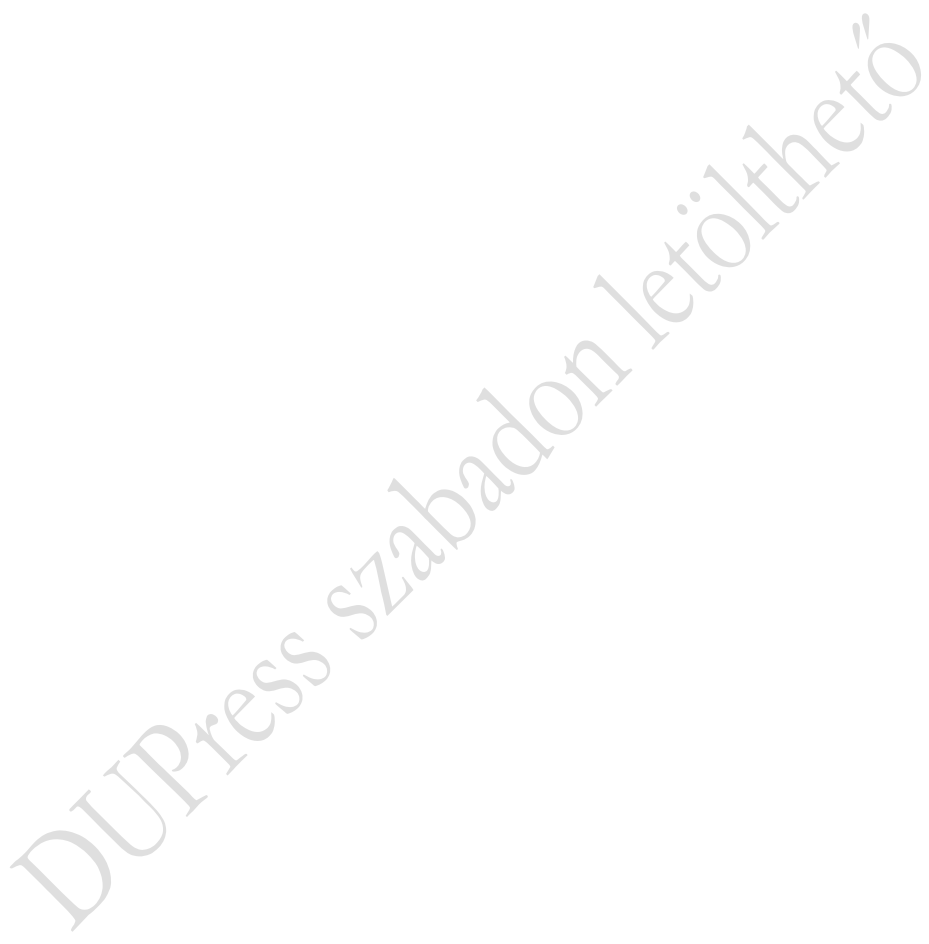




\title{
A KÖRNYEZETVÉDELMI SZABÁLYOZÁS HELYI SZINTJE
}

\author{
Fodor László ${ }^{*}$
}

A helyi érdekek, értékek védelme a negatív hatással járó, globális jelenségekkel szemben (legyen szó környezeti, piaci, szociális vagy más hatásokról) a társadalmi fenntarthatóság egyik kulcskérdése. A természeti erőforrások hasznosításának a helyi közösségek érdekkörében és kompetenciájában való meghagyása, a piaci igények helyi erőforrásokkal (termékekkel, szolgáltatásokkal, munkaerővel) való kielégítése, a termelési és fogyasztási viszonyok decentralizált szerkezetü, emberi léptékü (pl. energetikai) rendszerben történő szervezése pedig a környezeti fenntarthatóság egyre elfogadottabb peremfeltétele. Nem véletlen, hogy világszerte egyre fontosabbnak tartott szintje a környezetpolitikának a helyi - települési szint.

Jelen tanulmány csupán részeredményeket fogalmaz meg. Az az átfogó kutatás, amelyiknek a keretei közé illeszkedik, a települési önkormányzatoknak a környezeti fenntarthatóság megteremtésében játszott illetve lehetséges szerepére irányul. ${ }^{1}$ Középpontjában a magyarországi viszonyok állnak.

\section{Problémafelvetés}

Tisztában vagyunk a realitással, hogy a helyi önkormányzatok jogi, politikai mozgástere meg sem közelíti azt a mértéket, amelyik a fenntarthatóság szempontjából ideális lehet. Azt is látjuk, hogy a helyi önkormányzatiság hazai alkotmányjogi koncepciójának az

\footnotetext{
* Prof. Dr. Fodor László, PhD, tanszékvezető egyetemi tanár, Debreceni Egyetem Állam- és Jogtudományi Kar, Agrárjogi, Környezetjogi és Munkajogi Tanszék, fodor.laszlo@law.unideb.hu. A tanulmány a K 115530 ny. sz. kutatási projekt keretében, a Nemzeti Kutatási, Fejlesztési és Innovációs Hivatal támogatásával készült.

${ }^{1}$ A kutatás hipotéziseire és módszereire ld. FODOR László - BARTA Attila - FóNAI Mihály-BÁNYAI Orsolya: Települési környezetvédelem Magyarországon: Egy kutatás előfeltevései. Tér és Társadalom 2016/3, 19-39.
} 
utóbbi években bekövetkezett változása, miszerint az önkormányzatok már nem annyira alulról építkező, s a központi kormányzattal szemben alapjogokkal bíró aktorok, hanem inkább az egységes államon belül képeznek szervezeti egységeket, amelyek csökkenö autonómiával rendelkeznek, s az azzal összhangban zajló törvénymódosítások (mint az önkormányzati szervek korábbi államigazgatási jogköreinek a kormányhivatalokra telepítése, számos területen - állattartás, hulladékkezelés - a rendeletalkotási hatáskör elvonása, beszükülése) a környezetvédelemre is kihatnak. Az önkormányzatok komoly veszteségeket könyvelhetnek el más területeken is. ${ }^{2}$ Ez azonban éppen, hogy nem csökkenti, hanem erösíti a témakör aktualitását.

Ebben az előadásban az alkalmazott, különböző társadalomtudományi (jogtudományi, államtudományi, politikatudományi és szociológiai) megközelítések közül kifejezetten csak jogi kérdések kerülnek szóba, miként arra a cím is utal. Szabályozás alatt itt alapvetően csak a jogi, vagyis önkormányzati rendeletek útján történö szabályozást értem, ennek egyes kérdéseit igyekszem felvetni és megválaszolni.

Az önkormányzati rendeletekben megjelenő környezetvédelmi szabályozás, a kapcsolódó eszközrendszer müködése a tudományos szakirodalom szempontjából szürke zóna. Viszonylag keveset tudunk róla, hiszen a kapcsolódó publikációk száma igen kevés (vagyis a jogtudomány nem is igazán tekinti kutatási tárgyának), $\mathrm{s}$ többnyire nem is kifejezetten erről szólnak, hanem vagy jóval szükebb, vagy sokkal tágabb megközelítést alkalmaznak. (Viszonylag gazdag szakirodalma van az önkormányzati rendeletalkotás törvényességi ellenőrzésének. Van, aki szisztematikusan vizsgálja a jogszabályszerkesztés elveinek az érvényesülését a helyi jogalkotás szintjén, de kifejezetten környezetvédelemmel foglalkozó, $\mathrm{s}$ a rendeletalkotáson a szakmaiságot számon kérő kutatás korábban nem folyt). ${ }^{3} \mathrm{Az}$

\footnotetext{
${ }^{2}$ Az utóbbi évek centralizációs fordulatának (amelyek lényege az alkalmassá tétel helyett a szerkezeti problémák fenntartása, ugyanakkor a feladatok államosítása) az összefoglalására ld. PÁLNÉ KovÁCs Ilona: A magyar területi közigazgatási reformok főbb állomásai. In: Pálné Kovács Ilona: A magyar decentralizáció kudarca nyomában, Dialóg Campus, Budapest-Pécs, 2016, 82-85.

${ }^{3}$ A tágabb (más feladatokra is kitérö) témakör első és egyetlen, átfogó bemutatása 1999-ben született, de inkább az útmutatás, mint a feldolgozás igényével. Ld. Bándi
} 
alkotmányjogi megközelítésekből látható, hogy ezen a jogalkotási és jogérvényesítési szinten már (a központinál) nehezebben követhető nyomon a jog müködésére vonatkozó jogállamisági követelmények érvényesülése, s a törvényességi ellenörzés vagy az ombudsmani gyakorlat is csak a kirívó (tipikus) szabálytalanságokat képes megragadni. $^{4} \quad \mathrm{Ez}$ egyfelöl elkedvetlenítheti a témakörrel foglalkozókat, hiszen így nehéz elméleteket „gyártani,” az elméletet és a realitást ütköztetni, másfelől viszont a kitartó, s a jogi szabályozás eme legmélyebb bugyraiba leereszkedő kutató számára valóságos aranybánya nyílhat meg. Hiszen feltételezhetően bỏven talál apropót a véleményalkotásra, jobbító szándékú észrevételek, javaslatok megfogalmazására, akár a normaalkotás, akár az érvényesítés területén. $\mathrm{Az}$ is hipotézise lehet egy ilyen megközelítéssel élő kutatásnak, hogy a környezetvédelmi tárgyú, helyi szabályok vizsgálata révén nem csak erre a (szüknek amúgy sem mondható) szakterületre vonatkozó következtetések vonhatók le, hanem szükségszerüen feltárul egy általánositható kép is a vizsgált települések rendeletalkotásáról, a helyi és a központi szabályozás

viszonyáról.

Gyula (szerk.): Önkormányzati környezetvédelmi kézikönyv, KJK, Budapest, 1999. Amennyiben az Alkotmánybíróság illetve a Kúria foglalkozott egy-egy kérdéssel, esetenként annak szakirodalmi visszhangja is van, pl. BALOGH Zsolt: A környezetvédelem, köztisztaság problémái az önkormányzati rendeletek törvényességi vizsgálata során. Új Magyar Közigazgatás 2014/2, 84-87.; illetve egy-egy más (általános, alkotmányjogi) tárgykörben végzett kutatás során is szóba kerül a környezetvédelem is, szép példákon keresztül. Utóbbira ld. TILK Péter: A jogalkotási követelmények és az önkormányzati jogalkotás viszonya - hibák, törvénysértések a gyakorlat tükrében. In: Tóth Judit (szerk.) Ünnepi kötet Dr. Tóth Károly címzetes egyetemi tanár 70. születésnapjára, Szegedi Tudományegyetem Állam- és Jogtudományi Kar, Szeged, 2015, 614-631.; PACZOLAY Péter: Az önkormányzati rendeletek törvényességi és alkotmányossági kontrolljának kérdéséhez. In Gerencsér B., Takács P. (szerk.): Ratio legis, ratio iuris - liber amicorum: studia A. Tamás septuagenario dedicata (ünnepi tanulmányok Tamás András tiszteletére 70 . születésnapja alkalmából), Szent István Társulat, Budapest, 2011, 224-233. Az uniós jognak való megfelelés szempontjából is célkeresztbe kerültek ide kapcsolódó tárgykörök, ld. FOGARASI József: A helyi önkormányzatok és a jogharmonizáció néhány összefüggése 1990-2012 között II. Comitatus 2012 (209), 50-59. A törvényességi felügyelet/ellenőrzés kérdéseivel foglalkozik pl. Hoffman István: HOFFMAN István: Az önkormányzati rendeletek bírósági felülvizsgálata a Kúria Önkormányzati Tanácsa gyakorlata tükrében. Magyar Jog 2014/6, 340-349.

4 Ennek okát lényegében a kormányhivatali kapacitáshiányban látja GYERGYÁK Ferenc: Az önkormányzati rendeletek törvényességi felügyelete 2012-2014. Ú Magyar Közigazgatás 2016/1, 52. 


\section{Röviden a kutatás kereteiről}

Kutatócsoportunk valamivel több, mint egy évvel ezelött kezdte el a munkát, $\mathrm{s}$ kevesebb, mint másfél évünk van még a vállalásaink teljesítésére (a projekt időtartama 2015. 09. 1. - 2018. 02. 28.). Az már most belátható azonban, hogy a kutatás a projekt időtartamának letelte után is, akár hosszú évekig folytatható még, azt - a teljes körü feldolgozás igényével - befejezni nem, legfeljebb a kutatási terv által kijelölt ponton abbahagyni lehet.

A különböző, egymásra épülő módszerekkel zajló vizsgálat első lépéseként a legfontosabb, központi jogszabályokat (az Alaptörvényt, a Magyarország önkormányzatairól szóló törvényt, a környezetvédelmi törvényt $\mathrm{s}$ néhány ágazat szakterületi szabályait) tekintettük át, amelyek szabályozzák az önkormányzati kompetenciát. Alkotmánybírósági és kúriai döntéseket, ombudsmani jelentéseket gyüjtöttünk ki, a minél teljesebb feldolgozás igényével. Vizsgálva a helyi és a központi szint egymáshoz való viszonyát, több helyi önkormányzat saját rendeleteit, környezeti tárgyú programjait, rendezési terveit, szervezeti megoldásait is nagyító alá vettük. A kutatásnak ez a munkarésze még nagyobbrészt elöttünk áll, s több irányban is továbbvezet minket. Egyfelöl - magától értetődően igyekszünk a helyi környezetvédelmi szabályozás értékelését ezeken keresztül (is) elvégezni (induktív megközelítés). Másfelől esettanulmányokat készitünk, ami egy-egy település (tucatnyi, különböző típusú település, az ország különböző területeiről) esetén teljes körü, részletes feldolgozást jelent, a konfliktustérkép felvázolásától a választott szabályozási és egyéb megoldások értékeléséig (problémafeltáró, elemző módszer). Végül, arra is lehetőségünk van, hogy néhány szakterületen (sajnos korántsem mindegyiken) ágazati jellemzőket azonosítsunk be, s így egy-egy környezetvédelmi szektor helyi szabályozására nézve vonjunk le következtetéseket. Ilyen, már bemutatott ágazat a távhöszolgáltatás, de foglalkoztunk már a klímavédelemmel, hulladékgazdálkodással, és a vizgazdálkodással is; valójában itt is induktív megközelítést alkalmazunk, és pl. a témakör egyes pénzügyi jogi, nemzetközi jogi vonatkozásait is feltárjuk.

Hipotéziseink (amelyekből - már eleve szükítve a kutatás fókuszát - tucatnyit fogalmaztunk meg kiindulópontként) kisebb része akár iróasztal mellett is igazolható, - pl. a helyi rendeletek 
elvben teljes körüen elérhetők az interneten keresztül, így azokról tartalomelemzést tudunk végezni - többségük azonban empirikus módszerek alkalmazását igényli.

Ehhez - a fontosabb problémákra, az elmúlt évek jelenségeire koncentráló elővizsgálatok alapján, s többek közt a Települési Önkormányzatok Szövetségével és a Belügyminisztériummal történt kapcsolatfelvétel nyomán - online kérdőiv kitöltésére kértük meg az önkormányzatokat. (Jelenleg több mint 260 településről vannak válaszaink, amelyeket kérdezőbiztosok bevonásával egészítünk még ki a közeljövőben ennek duplájára, ami kellő reprezentativitást kölcsönöz a kutatásnak.) A mintaválasztás során a településtípusok mellett a településeknek a környezeti állapotát, „érintettségét” is figyelembe vesszük.

Esettanulmányokat sajnos csak kb. tucatnyi településröl, fővárosi kerületről tudunk most készíteni. ${ }^{1}$ Ehhez az interneten elérhető rendeletek, programok, jegyzőkönyvek és egyéb dokumentumok, a helyi sajtó tanulmányozásán alapuló „előtanulmányokat végzünk,” utána már megfelelő ismeretekkel felvértezve, az adott önkormányzat valamennyi illetékesének bevonásával fókuszcsoportos interjúkat veszünk fel, megkeressük az adott település civil szervezeteit is, betekintünk az interneten esetleg nem elérhető, egyéb dokumentumokba, amelyekhez a hozzáférés lehetséges, stb.

$\mathrm{Az}$ interjúalanyok körébe (részint a látókör bővítése, részint a megfelelő kontrollvizsgálatok érdekében) a szakterület más szereplöit - így, pl. az ombudsmani hivatalt, szakosodott ügyvédi irodákat, az érdekelt kutatóhelyeket, illetve több, szakmailag érintett társadalmi szervezetet - is bevonjuk. ${ }^{2}$

A dokumentumok előzetes feltárása és a különböző forrásból származó adatok alapján végzett, elemző munka talán a legnehezebb részei ennek a folyamatnak.

${ }^{1}$ Az első publikált esettanulmányunk FODOR László: A környezetvédelem helyi szintje egy dél-borsodi kistelepülés, Bogács példáján. Miskolci Jogi Szemle 2016/2, $5-28$.

${ }_{2} \mathrm{Az}$ első kapcsolatfelvételek sikeresen megtörténtek, illetve pl. az ombudsmani hivatalban már le is zajlott a beszélgetés, s hogy számunkra igen hasznos együttmüködés alakult ki, azt jelzi az érintett hivatali munkatársak egy részének a konferencián való szereplése is, amiért itt is köszönetet tartozom mondani. 


\section{A környezet védelmét szolgáló helyi rendeletek köre}

A helyi rendeletek kutatásának első lépéseként igyekeztem meghatározni, vajon mely szabályozási tárgykörökhöz kapcsolódik a környezetvédelem, vagyis hogy a szakirodalom, a központi elöírások, az alkotmánybírósági és kúriai joggyakorlat tükrében milyen rendeletcímek mögött sejthető környezetvédelmi tartalom, amit majd a részletes vizsgálat során össze kell gyüjteni és elemezni kell. (Hol jelenik meg a helyi környezetpolitika?) Hipotézisként az alábbi tárgyköröket állapítottam meg: a környezetvédelem (mint integrált tárgykör), az önkormányzati környezetvédelmi alap, a településrendezés (ahol az épitésügy mellett jelenik meg a helyi környezetvédelem), a településképi eljárás, a helyi épitészeti örökség védelme, a települési szilárd hulladékkezelési közszolgáltatás, a köztisztaság, a közterület-használat, a hulladékok és a tarló égetése, a füstködriadó-terv, a zajvédelem, a helyi jelentöségü természetvédelmi terület létesitése, a zöldterületek és a fás szárú növények fenntartása illetve kezelése, a talajterhelési dijj, a háztartási szennyviz kezelése (ha az nem a közmübe kerül), az állattartás (amire vonatkozóan 2012-ben megváltozott a központi szabályozás, a legtöbb helyi rendelet hatályon kívül helyezését idézve elö). De környezeti vonatkozása van/lehet akár a közösségi közlekedés, a parkolási rend, a városrehabilitáció, a távhöszolgáltatás, az allergén növények elleni védekezés, a panelházak felújitásának támogatási feltételei, vagy a vagyongazdálkodás elöírásainak is. Meglehetősen széles körről van tehát szó, noha szükebbről, a korábbi években élvezett önkormányzati szabályozási mozgástérhez képest. ${ }^{1}$

Az elkészült, első esettanulmányok szerint azonban a valóság ettöl némileg eltérö. Egyrészt azért, mert más tárgykörök is komoly jelentőséggel bírnak, így különösen a közösségi együttélés szabályai. Számos település e címszó alatt szabályozza azokat a környezeti problémákat, amelyek a helyi társadalmi béke megörzését fenyegetik. Nem a hosszútávon, globális léptékben jelentkező környezeti hatásokra, vagy a környezetvédelmi szabályozás alapelveinek az érvényesítésére kell gondolni, hanem az együttélés napi szintü nehézségeire, a különbözö zavaró hatások (pl. zaj, füst,

\footnotetext{
1 FODOR László: A helyi szabályok eltérése a központi előírásoktól környezetvédelmi megfontolások. Jogtudományi Közlöny 2016/7-8., 354.
} 
büz, szenny) kiküszöbölésére. A magyarázat egyszerü: e tárgykörben vannak az önkormányzatnak lehetőségei szankciók megállapitására és alkalmazására (bizonyos értelemben a közösségi együttélés szabályainak a megsértése váltotta fel a szabálysértéseket, illetve a kirívóan közösségellenes magatartásokat, amelyek körében a helyhatóságok kompetenciája 2012/13-ban megszünt). ${ }^{2}$ Hasonló logikával kapcsolható ide a közterület-használat illetve a közterületfelügyelet szabályozása is. Az elöírások érvényesítése szempontjából ugyanis komoly jelentősége lehet annak, hogy a településnek van-e felügyeleti intézménye, $\mathrm{s}$ hogy az a környezeti hatással járó tevékenységeket a valóságban ellenőrzi-e. Másként fogalmazva: jellemző, hogy azon környezetvédelmi elöírásokat, amelyeknek ténylegesen érvényt kíván szerezni az önkormányzat, e két szabályozási tárgykörhöz (mint eszközhöz) is hozzákapcsolja, de az is elöfordul, hogy egyes környezetvédelmi elöírások (tényállások) kifejezetten csak itt jelennek meg.

Az említett esetekben kemény, rendészeti eszközökről van szó, amelyeknek a rendelkezésre állása hívja életre vagy erősíti meg a környezetvédelmi szabályt. Elöfordul azonban olyan is, hogy egészen más típusú, gazdasági eszközhöz kapcsolódik a környezetvédelem: pl. a helyi civil szervezetek támogatásának lehet (rendeletben megállapított) szempontja az, hogy a szervezet folytat-e valamilyen környezetvédelmi tevékenységet.

Továbblépve, az említetteken kívüli szabályozási tárgykörök megjelenése sokszor a helyi sajátosságokból, igényekböl is következhet. Jellemzö, pl. hogy az idegenforgalom érdekeit szem elött tartva hoznak az önkormányzatok rendeleteket, amelyek tárgya konkrétabb a megszokottnál. Ha szabad egy közelmúltbeli kirándulásomnak a helyszínen kifüggesztett és olvasott „leletét” példaként felhozni, akkor ilyen a Felsötárkányi tó és környékének használatáról és rendjéről szóló jogszabály, amelyben többek közt megjelennek a köztisztasági, közterület-használati és levegővédelmi szempontok is. ${ }^{3}$

\footnotetext{
2 TILK Péter: A helyi „szabálysértések” fönixmadarai - a közösségi együttélés alapvető szabályait sértő magatartások. Új Magyar Közigazgatás 2013/12, 28-28. (számos, környezetvédelmi szempontból releváns példával, illetve első sorban alkotmányjogi szempontú kritikával találkozunk itt).

3 Felsőtárkány Község Önkormányzata Képviselö-testületének 2/2012. (I.18.) önkormányzati rendelete a Felsőtárkányi tó és környékének használatáról és rendjéről.
} 
Mindemellett jellemzö, hogy egy-egy nagyobb település esetén több tárgykör jelenhet meg, mint a kisebbek esetén, ami megint csak sok összefüggésre vezethető vissza. Pl. Miskolc esetén olyan tárgykörök is szóba jönnek még, mint a védett síremlékek vagy a sátorozás (de a releváns szabályok közt a helyi adókról, a közmüfejlesztési hozzájárulásról és a víziközmü-szolgáltatásról szóló rendeleteket is kigyüjtöttem.)

De ha az előfeltevéseket és a számomra napról napra élesedő helyzetképet ütköztetem, akkor azt is el kell mondani, hogy számos olyan szabályozás, amelyet általános környezetjogi ismereteim alapján minden települési önkormányzat esetén meglévőnek feltételeztem, sok esetben hiányzik. Távhö-szolgáltatási rendeletet nyilván nem vártam minden településtöl, hiszen ilyen szolgáltatással csak mintegy 70-80 település rendelkezik, de azt gondoltam, hogy környezetvédelmi rendelet mindenütt van, illetve legalább a nagyobb (közlekedéssel, iparral érintett) településeknek zajvédelmi, levegővédelmi szabályozása biztosan van. A várakozás csak a települések egy része esetén teljesült.

$\mathrm{Az}$ önkormányzatok egy része ugyanis a környezetvédelmet (vagy legalábbis annak a hatáskörébe tartozó részét) nem a maga komplexitásában szemléli, hanem csak a számára, a ma élő nemzedékek, a helyi közösség számára fontos kérdésekre gondol. Ez, mondhatni egy szük látókörü, bár ugyanakkor bizonyos mértékig érthetö, praktikus szemlélet. Ennek ellenpontját képezik az olyan helyhatóságok, amelyek minden, a központi elöírásokban megnevezett környezeti elemre és hatótényezöre elöirásokat hoznak (nem feltétlenül környezetvédelminek is nevezett jogszabályokban), függetlenül attól, hogy van-e arra hatáskörük. Ezen utóbbi megoldások többsége azonban formális, végre nem hajtható, $\mathrm{s}$ nem egyéb (nem is lehet egyéb), mint a központi elöírás kivonatolása (e kérdésre a következő pontban még röviden visszatérek majd).

Vannak aztán olyan önkormányzatok is, amelyek a környezetvédelmi tárgykörök közül csak a nekik fontosakat rendezik, de azt is „elrejtik” egyéb rendeleteikbe, különösen a már emlitett közösségi együttélési szabályokba, a helyi épitési szabályzatba, netán közterület-használati rendjükbe. Az, hogy ezen rendeleteknek van környezetvédelmi funkciója, az közismert. De ez nem jelenti azt, hogy bármely tárgykör belefér ezekbe. Így ha, pl. az ingatlanon történö hulladékégetésre vonatkozó elöirások a HÉSZ-ben és/vagy a 
közterület-használat szabályai közt kapnak helyet, akkor azt kell mondanunk, hogy a jogszabály címe, bevezetöjében meghatározott tárgyi hatálya és az előírások, vagyis a tartalom nincsenek teljesen összhangban egymással. Mivel az ilyen szerkesztési mód nehezen megismerhetővé teszi a helyi követelményeket, s bizonytalanná teszi a szabályozás hatályát, a jogállamiság követelményével ellentétes, illetve nem felel meg a jogszabályszerkesztés központilag meghatározott követelményeinek. ${ }^{4}$

Némelyik önkormányzat még ezen is túllép. Arra is találtam példát, hogy egy önkormányzat ugyanannak az életviszonynak a szabályait több rendeletben is megfogalmazta, amire nyilván az a szándék vezette, hogy nagyon szeretne érvényt szerezni az elvárásainak. Pl. Bogácson három-három rendelet is korlátozza az avar és a kerti hulladékok égetését, illetve tiltja a település erdeiben a tarvágást. Amellett, hogy utóbbi tárgykör nyilvánvalóan nem tartozik az önkormányzat hatáskörébe, mindkét esetben probléma az is, hogy az egyes jogszabályok elöírásai közt tartalmi eltérések vannak (pl. abban, hogy az év pontosan melyik időszakában tilos a nyílt téri égetés), ami megint csak ellentétes a jogállamiság elvével.

Ha a „hiányokat” említem, akkor feltűnő, hogy a vizsgált települések egyike sem tudta (akarta) aprópénzre váltani vagyonrendeletében az Alaptörvény 38. cikkében foglalt iránymutatást, a természeti erőforrások kímélete, a jövő nemzedékek szükségleteinek kielégítése vonatkozásában. Esetenként azonban, pl. az önkormányzati földek hasznositásának feltételei közt akad környezeti vonatkozású is ( $p l$. Miskolcon). Végül, előfordul az is, hogy egy településen jelentkeznek bizonyos környezeti problémák, amelyek rendezése körében lenne is az önkormányzatnak hatásköre (pl. zajvédelmi szabályozás), de mégsem születik rendelet ( $p l$. csendes övezet kijelöléséröl), abból a „praktikus” megfontolásból, hogy a helyhatóság a gyakorlatban nem tudná azt érvényesiteni. ( $\mathrm{Pl}$. Debrecenben nyilatkoztak így interjúalanyaink, de a kérdőíves kutatás során kapott válaszok egy része is azt panaszolja, hogy túl szigorúak a központi határértékek ezen a területen).

Következtetéseim ebben a pontban:

1) Az, hogy a leirt jelenségek mennyire tekinthetök tipikusnak, még további vizsgálatokat igényel.

\footnotetext{
${ }^{4}$ 61/2009. (XII. 14.) IRM rendelet a jogszabályszerkesztésről.
} 
2) Ha egy-egy település környezetvédelmi elöírásait (vagy különösen, ha egy-egy részterületet) teljes körüen fel akarjuk tárni, akkor ahhoz nem elegendö a jogszabályok címéböl kiindulni. A vizsgálati tárgykör adott esetben sokkal szélesebb lehet.

3) Ugyanakkor a keresést egészen más szemlélettel kell végeznünk, mint a központi elöírások körében. Persze, akadnak olyan települések, amelyeken könnyen megismerhetök a szabályok (pl. Miskolcnak saját hivatalos közlönye van, a rendeleteket el lehet érni az önkormányzati honlapon és többnyire a Nemzeti Jogszabálytárban is, a közgyülési jegyzőkönyvek kb. 10 éve, mellékleteikkel együtt elérhetők a saját honlapon, a jogszabálycímek és az elöírások tartalma túlnyomóan összhangban van egymással), de elöfordul az is (pl. a már többször említett Bogács esetén), hogy a jogszabályszerkesztés kaotikus (és a normaszövegeken túl gyakorlatilag minden egyéb dokumentumtípus esetén csak részleges a hozzáférés).

4) Megállapítható végül az is, hogy a Nemzeti Jogszabálytár feltöltöttsége hiányos, a kisebb települések jelentös része pedig nem rendelkezik saját honlappal, vagy ha igen, az nehezen áttekinthetö, s mivel így a helyi rendeletek nyilvánossága nem érvényesül teljes körüen, esetenként a hatályos elöírások feltárása is csak több módszer együttes alkalmazásával történhet meg.

\section{Néhány vitatható megoldás a helyi rendeletekben}

Az Alaptörvény 31. cikk (2) bekezdése szerint „Feladatkörében eljárva a helyi önkormányzat törvény által nem szabályozott helyi társadalmi viszonyok rendezésére, illetve törvényben kapott felhatalmazás alapján önkormányzati rendeletet alkot." A következő cikkböl megtudjuk azt is, hogy az önkormányzat rendelete „más jogszabállyal nem lehet ellentétes."

Külön kérdés, amivel itt nem foglalkozom részletesen, hogy mennyiben és milyen feltételekkel lehetséges a központi elöirásokhoz képest szigoritani, anélkül, hogy törvényellenes lenne a választott megoldás; tekintettel az Alaptörvény és a Mötv. általános előírásaira, illetve az 1995:LIII. törvény (Kvt.) 48. § (1) bekezdésére.

Természetesen nagyon valószínű, hogy a helyi elöírások túlnyomó többsége megfelel a központi elöírásoknak. Ugyanakkor a szakirodalom, illetve a bírói gyakorlat is jelzi, hogy vannak 
problémák, amelyek egy része - tömeges előfordulása okán - akár típushibaként is értékelhető. Az alábbiakban néhány ilyen problémával kapcsolatos, első tapasztalataimat osztom meg.

a) A Környezeti Management és Jog Egyesület munkatársai 2011-ben - 139 település rendeleteinek vizsgálata alapján - gyakori jelenségként értékelte, hogy azok zajkibocsátási határértéket rögzitenek. ${ }^{5}$ Szúrópróbaszerüen több tucat helyi önkormányzatot választottam ki kifejezetten ennek a jelenségnek az igazolására, $\mathrm{s}$ azt találtam, hogy öt évvel később is jellemző megoldásról van szó, egyébként gyakran nem is a zajvédelemröl szóló rendeletben, hanem pl. a vendéglátóhelyek nyitva tartása, a közösségi együttélés szabályai vagy a HÉSZ rendelkezései közt. A határértékek egy része nem kibocsátási, hanem „környezetszennyezési” határértéknek tűnik ugyan (pl. Füzéren, ahol „Zenés szórakozóhelyek környezetében megengedett hangnyomás szint $50 \mathrm{~dB}$."), de ennek nincs jelentősége a központi elöíráshoz való viszony tekintetében. A Kvt. 89. § (3) bekezdése alapján ugyanis határértéket csak a miniszter, vagy jogszabály alapján a hatóság állapithat meg. A kúriai gyakorlat alapján az önkormányzat rendelete utalhat a központilag rögzített határértékre, de azt még csak meg sem ismételheti, nemhogy más értéket állapithatna meg. ${ }^{6}$ Izgalmas Bogács esete, ahol a jelenlegi (törvényellenes) szabályozás többéves vívódás eredménye, az önkormányzat mérőeszközt is beszerzett, és a közterületfelügyelőket ki is küldik ellenőrizni a vendéglátóhelyek teraszán történő zeneszolgáltatásra megállapított, zajterhelési határérték betartását. $^{7}$

Ugyanezen logika alapján törvényellenes, ha az önkormányzat $a$ központitól eltérö, netán annál enyhébb határértéket rögzit, de itt már a Kvt. 48. §-ában rögzített korlátozó rendelkezés is sérül (miszerint az önkormányzat kizárólag szigorúbb elöírást állapíthatna meg), és akár az alaptörvény-ellenesség is megállapítható lenne (a környezethez való jog sérülése miatt). Nem közvetlenül

5 GAJDICS Ágnes, KISS Csaba, SzILÁGYI Szilvia: Települési önkormányzatok lehetöségei a zaj elleni küzdelemben. A helyi rendeletalkotás keretei. Budapest, EMLA, 2011, 49.

${ }^{6}$ FODOR: A helyi szabályok eltérése... i.m., 357.

${ }^{7}$ A településröl készült esettanulmányt ld. FODOR László: A környezetvédelem helyi szintje egy dél-borsodi kistelepülés, Bogács példáján. Miskolci Jogi Szemle 2016/2, 5 28. 
végrehajtható elöírás ugyan, de így kell megítélni Miskolc zajvédelmi rendeletét, amelyik egyfelöl a településrendezés körébe utalja a zajvédelmi követelmények érvényesítését, másfelöl „megengedi” a központi elöírásokban megadott zajterhelési határértékektől való eltérést (legyen szó akár szigorításról, akár enyhítésről) a zajvédelmi szempontból fokozottan védett területeken.

b) Klíma- illetve levegővédelmi szempontból egyaránt jelentős kérdés az épületek energiaellátása, ezen belül is a fütés. A fütési módok szabályozása jelenleg a magyar jogrendszer szürke zónái közé tartozik. A központi és a helyi szabályozás viszonyára vonatkozóan az Alkotmánybíróság 5-7 évvel ezelött több határozatában is állást foglalt, kigyomlálva a helyi (budapesti, tatai, pécsi, miskolci, tiszaújvárosi) rendeletek törvényellenes megoldásait. ${ }^{8}$ Eszerint nem megengedett, pl. a távhöre csatlakozás elöirása, a leválás megtiltása, egyáltalán a fütési módok kikötése, legyen szó jogforrásként távhöszolgáltatási, levegövédelmi rendeletröl, vagy HÉSZ-röl. Az akkori határozatok, illetve a most hatályos központi és helyi elöírások áttekintése, illetve összevetése azonban azt mutatja, hogy míg egyes önkormányzatok (Budapest, Pécs) elfogadták a döntéseket, addig mások (pl. Tiszaújváros, Miskolc, vagy az $\mathrm{AB}$ által nem vizsgáltak közül Mátészalka) továbbra is a törvényesség határain túlterjeszkedö vagy azokat feszegetö megoldásokat alkalmaznak. Csak a legerőteljesebben korlátozó rendelkezések egyes típusai (pl. a távhőszolgáltatás kizárólagosságának elöírása) tüntek el, ugyanakkor többféle és körmönfontabb elö́rás érvényesül e körben (pl. teljes közmüvesítettség előírása az építési engedély feltételeként, amibe beleértik az elöírt fütési módok valamelyikének az alkalmazását). A települések mozgástere véleményem szerint túl szük (és külső okokból egyre szükebb), amit központilag - erősebb önkormányzati kompetenciák biztosításával, energiapolitikai intézkedésekkel -

\footnotetext{
${ }^{8}$ 28/2011. (III. 31.) AB határozat (ABH 2011, 682), 126/2009. (XII. 17.) AB határozat (ABH 2009, 1297), 59/2009. (V. 22.) AB határozat (ABH 2009, 1152), 21/2009. (II. 26.) $\mathrm{AB}$ határozat ( $\mathrm{ABH} 2009,1083), 22 / 2009$. (II. 26.) $\mathrm{AB}$ határozat ( $\mathrm{ABH} 2009$, 1090); PACZOLAY: i.m., 228.
} 
kellene tágítani. Emellett szól a szolgáltatásnyújtás biztonsága és a klíma- illetve levegővédelem szempontja. ${ }^{9}$

c) Egy fontos környezetvédelmi problémára, s annak nem megfelelö önkormányzati szabályozására, egyúttal a központi elöírás hibájára mutat rá az alapvető jogok biztosa. ${ }^{10}$ Jelentése szerint mind a jogállamiság elvét, mind a környezethez való jogot illetően visszás, hogy a Kvt. az avar és a kerti hulladék égetésének szabályozására feljogosítja az önkormányzatokat, illetőleg hogy a tilalmazó központi előírások (levegővédelmi rendelet, tüzvédelmi szabályzat) eltérő elöírások megalkotására ad felhatalmazást, hiszen a környezethez való jog, s az azt érvényesítö, a hulladékra vonatkozó törvényi elöírások szerint a biológiailag lebomló hulladéknak a komposztálását kellene szabályozni és megoldani. A rossz hatásfokú égés rendkívül veszélyes légszennyező anyagok levegőbe kerülésével jár, ami egyébként a helyi környezetben zavaró is. Mindehhez hozzátehetjük, hogy a Kvt. már említett előírása (48. §) csak a szigorúbb szabályozásra ad módot az önkormányzatoknak. Ha megvizsgáljuk a helyi önkormányzatok rendeleteit (az ombudsman eljárását kezdeményező Levegő Munkacsoport is élt a lehetőséggel, illetve még a jelentés nyilvánosságra hozatala előtt én is számos településen vizsgálódtam), látható, hogy a központi elöírásoknak való megfelelés szempontjából meglehetösen ellentmondásos a kép. Említést érdemel, hogy számos önkormányzat (pl. Mátészalka, Gönc) úgy szabályozza és engedi meg a hulladékégetést, hogy elöbb egy a komposztálásnak prioritást biztositó követelményt rögzit (netán kiköti, hogy az égetés csak kivételesen, indokolt esetben lehetséges). Sajnos azonban e követelménynek a betartatásához nincsenek megfelelö eszközök, illetve szempontok (mint az ombudsman is megállapítja, szükség lenne egy a komposztálásra vonatkozó, központi szabályozásra). Minta lehetne a föváros, amelynek teljes területén tilos az égetés. Az ombudsmani jelentés nem vonatkozik a tarlóégetésre egyébként, ahol hasonló problémákról beszélhetünk. ${ }^{11}$

\footnotetext{
${ }^{9}$ A tárgykörben folytatott elemzéseim részleteire ld. FODOR László: Klímavédelem vs. törvényesség a távhőszolgáltatás helyi szabályai kapcsán. Magyar Jog 2016/11, kézirat megjelenés alatt, 13.

${ }^{10} \mathrm{Az}$ alapvető jogok biztosának és a jövő nemzedékek érdekeinek védelmét ellátó helyettesének Közös jelentése az AJB - 695/2016. számú ügyben. 2016. február.

${ }^{11}$ FODOR: A helyi szabályok eltérése... i.m., 360.
} 
d) A központi elöirások a környezetvédelem területén különösen gyakran változnak, ami rugalmas alkalmazkodást követel meg a települési önkormányzatoktól. Pl. a hulladékkezelési közszolgáltatás területén a közelmúltban elöfordult, hogy évente többször is módositani kellett a helyi elöírásokat. Több tárgykörben a hatályon kívül helyezés volt az egyetlen lehetőség. Pl. ombudsmani jelentések és kúriai határozatok egyaránt problémákat jeleztek a 2013-tól hatályos hulladéktörvény kapcsán, amely miniszteri hatáskörbe vonta a települési hulladékkezelési közszolgáltatási dij szabályozását, és hasonló problémák merültek fel a 2011-töl hatályos levegövédelmi kormányrendelettel összefüggésben is, amely többek közt megújította a szmogriadóra vonatkozó elöírásokat. ${ }^{12}$ Tipikus egyébként, hogy az önkormányzatok egy része, ha késve is, de ilyen esetekben módosítja a nyilvánvalóan törvényellenes elöírásait, viszont nem feltétlenül figyel arra, hogy az új központi elöirás fogalomrendszerét, megváltozott szellemiségét is átvegye. ${ }^{13}$ Ezek az esetek azt is példázzák, hogy a központi jogszabályok gyakori módosulása, illetve a hatáskörök megosztása az illetékes miniszter és a települési önkormányzatok között újabb és újabb bizonytalanságokat idéznek elő. ${ }^{14}$

De a központi elöŕráshoz való igazodás, illetve a rugalmasság igénye nem csak ebben mutatkozik meg. Pl. tárgykörtől függetlenül, a jogszabályszerkesztésről szóló (már hivatkozott) IRM rendelet (17.

\footnotetext{
${ }^{12}$ Ld. pl. a 28/2011. (III. 31.) AB határozatot (ABH 2011, 682) illetve a Kúria Köf. $5012 / 2013 / 4$, Köf. 5015/2013/6, Köf. 5016/2013/6 és Köf. 5076/2013/3. és az alapvető jogok biztosa által kezdeményezett 5018/2013/6. sz. határozatait. De 2010 után az ebtartás helyi szabályozása sem esik már a helyi jogalkotás tárgykörébe, amivel kapcsolatban ugyancsak problémák merültek fel; 146/2011. (XII. 2.) AB határozat (ABH 2011, 829.); Köf. 5046/2013/7.

${ }^{13}$ Az általunk végzett kérdőíves kutatás eredményei azt mutatják, hogy a központi szabályokhoz való igazodás első sorban (a válaszadók 41\%-ánál) a már hatályos helyi rendelet módosításával, s csak kisebb részben (27\%) új jogszabály elfogadásával történik. Emellett előfordul az is, hogy a központi jogszabály szövegét veszik alapul a szerkesztésnél (15\%), illetve hogy egymástól vesznek át megoldásokat a helyhatóságok $(17 \%)$.

${ }^{14} \mathrm{Az}$ alapvető jogok biztosának és a jövő nemzedékek érdekeinek védelmét ellátó helyettesének Közös jelentése az AJB - 4211/2014. számú ügyben; SzILÁGYI EMESE: Mennyit ér a közszolgáltatás? A hulladékkezelési díjszabás alkotmányos problémái. kozjavak.hu - Az MTA-DE Közszolgáltatási Kutatócsoport blogja, 2015. október 4. http://www.kozjavak.hu/sites/default/files/szilagyi.emese_mennyit_e_r_a_kozszolgalt atas.pdf (2016. 01. 21.); BALOGH: i. m., 87.
} 
§-ában) a rugalmas hivatkozást írja elö föszabályként, ami adott esetben a központi elöírás hatályon kívül helyezése esetén is fenntarthatóvá teszi a helyi elöírást, ha az tartalmilag nem ellentétes az új központi elöírással. Merev hivatkozás esetén, tehát ha a helyi rendelet pontosan hivatkozza az adott központi jogszabályt, akkor tartalmi probléma hiányában is módositani kell a helyi elöirást, mert (mint a Kúria egyes döntései arra rámutatnak), pusztán a hatálytalan központi elöírásra való utalás is törvénysértö. Majd minden környezetvédelmi részterület helyi szabályaiban merev hivatkozásokkal él, pl. Bogács, s azok közt így jelenleg több is már hatálytalan jogszabályokra utal. ${ }^{15}$

e) Már az előző pontban utaltam arra, hogy vannak olyan helyi elöírások, amelyek szövege leginkább a központi elöírás kivonatolásaként értelmezhető (rengeteg település, pl. Mátészalka, Bogács egyes levegővédelmi, hulladékgazdálkodási előírásai). Ez egyfelöl rontja a helyi rendelet normativitását (amennyiben nem végrehajtható, nem az önkormányzat hatáskörébe tartozó követelményekről van szó), másrészt ezek törvényellenesek, amennyiben a központi elöirást megismétlik (erre a Kúria az utóbbi időben meglehetősen érzékeny), vagy lerontják (kisebb településeken sokszor megfelelö környezetvédelmi - jogi szakismeret hiányában fogalmaznak meg ilyen elöírásokat; ezek törvényellenessége magától értetődő, de alkotmányellenességük is felmerül).

Értékelés ebben a pontban:

1) A helyi rendeletalkotás általános problémái a környezetvédelmi tárgykörökben is megmutatkoznak.

2) Látható, hogy számos törvényességi és alkotmányossági probléma adódik, vélhetőleg a helyi és a központi szint közötti hatáskörmegosztás bizonytalanságaiból, a központi szabályok gyakori változásából, a megfelelö szakértelem hiányából, s más okokból is, amelyek azonban csak további empirikus vizsgálatok, s szakirodalmi kutatás útján ismerhetők meg.

\footnotetext{
${ }^{15}$ Megállapításommal egybecsengően a BAZ Megyei Kormányhivatal - a helyi építési szabályzatok törvényességi ellenőrzése során - megállapította, hogy rendkívül sok a megyében a hatálytalan jogszabályra történő, merev hivatkozás. BO/13/52-2/2016, Miskolc, 2016, 9. pont. A dokumentum némely önkormányzat honlapján elérhető (Pl. Edelény, http://edeleny.hu/testuletiules/meghivo/2016/0526/104.pdf).
} 
3) Emellett nyilvánvaló, hogy a környezetvédelem szakterületi sajátosságaiból (a konfliktusok térbeli és időbeli eltolódása, komplex megközelítés és szakismeretek igénye, rövidtávon jelentkező - gazdasági, politikai - érdekekkel való konfliktusok jelentkezése, a helyi környezeti konfliktusok tipizálásának a nehézségei, stb.) további gondok következnek, amelyek teljes körü feltárása még várat magára (itt csupán példák kiragadására nyílt alkalmam).

4) Egyes szakterületeken a központi elöírások tételesen meghatározzák, hogy mely tárgykörök tartoznak önkormányzati szabályozási hatáskörbe, ugyanekkor e tárgykörökre vonatkozóan maguk is számos elöírást tartalmaznak. Ebből következően a hatáskör elhatárolása nehéz, $\mathrm{s}$ (részben legalábbis) ez eredményezi azt, hogy a helyi rendelet a központi elöírásban (pl. a hulladéktörvényben, a közszolgáltatási tevékenységet rendező kormányrendeletben, a levegővédelmi rendeletben) megfogalmazott elöírásokat átvevő, esetenként átfogalmazó, a jogállamiság követelményével nehezen összeegyeztethető rendelkezéseket tartalmaz. Az önkormányzatoknak a kiegészitö jellegü, illetve bizonyos esetekben a szigorúbb szabályozás célját kellene szem elött tartaniuk; ha ilyen céljuk nincs, akkor helyesebb, ha tartózkodnak a szabályozástól.

5) A helyi szabályozással kapcsolatos problémákat érdemes kellő óvatossággal értékelni. Erre két okot hozok fel:

5a) Elöfordulhatnak olyan, sajátos életviszonyok, amelyekre a központi elöirás nem ad megoldást, miközben a helyi közösség számára égető problémát jelentenek. Ilyenkor tartalmilag az lenne a helyes megoldás, ha a központi elöírás változna, vagy a helyi jogalkotó mozgástere szélesedne. ${ }^{16}$

5b) A helyi elöírások betarthatósága, feleslegesnek tünő volta, túlzott részletessége és különféle szerkesztési problémák megitélése nem minden esetben lehetséges önmagában a rendeletszöveg (és netán a központi elöirások) ismeretében. A helyi viszonyok (konfliktusok), a szabályozást megelözö viták, a különféle elöterjesztések (minimálisan a testületi jegyzőkönyvek), a kialakult

\footnotetext{
${ }^{16}$ Az általunk végzett kérdőíves kutatás eredményei azt mutatják egyébként, hogy maguk az önkormányzatok is változtatnának, pl. a központi hulladékgazdálkodási, környezet-, zaj-, levegő és természetvédelmi, vízgazdálkodási előírásokon.
} 
(ellenörzési, szankcionálási) gyakorlat tükrében adott esetben egészen más megállapításra juthat a kutató.

\section{Zárszó}

Fentiek alapján elmondható, hogy mindaz, amiröl ma beszámolhatunk, beszámolhatok, csupán részeredmény. Ugyanakkor a jelenségek és okok feltárását folytatjuk tovább, s a következő mintegy másfél évben - reményeink szerint - még rengeteg izgalmas eredménnyel szolgálhatunk.

Zárásként két gondolatot füznék össze, afféle - a kutatás lezárásához képest - előzetes következtetésként. Elöször is, a környezetvédelem egyik kulcsa a környezeti szempontoknak a beépítése a különböző döntésekbe. Ez a (külső) integráció igénye, jelensége, amely a fenntarthatóság egyik mozzanata $s$ garanciája egyben. ${ }^{16}$ Úgy vélem, az önkormányzati rendeletalkotás szintjén az integráció jelensége jól szemléltethetö, még akkor is, ha ezen a szinten ma távolról sem teljes a szabályozási tárgyak köre, mivel sok kérdés csak a központi szabályozásra tartozik, s mivel az önkormányzatok látóköre térben és időben egyaránt korlátozott. Másodszor, bízom abban, hogy ezek a körök tágíthatók. Az önkormányzatok együttmüködése, összefogása e szakterületre is kiterjedhet (nem csak, pl. egy hulladékkezelési szolgáltatás szervezése erejéig). Ha szélesebb szabályozási hatáskört, egyéb (tervezési, a végrehajtást segítő jogi, financiális) segítséget, (polgáraikkal együtt, akiket a jelenleginél szintén nagyobb mértékben lehetne motiválni) környezetvédelmi ismereteket kapnának, a fenntartható fejlődés jogi kereteinek érdemi alakítóivá válhatnának, válnának.

${ }^{16}$ BÁNDI Gyula: A fenntartható fejlődés jogáról, Pro Futuro 2013/1, 22. 


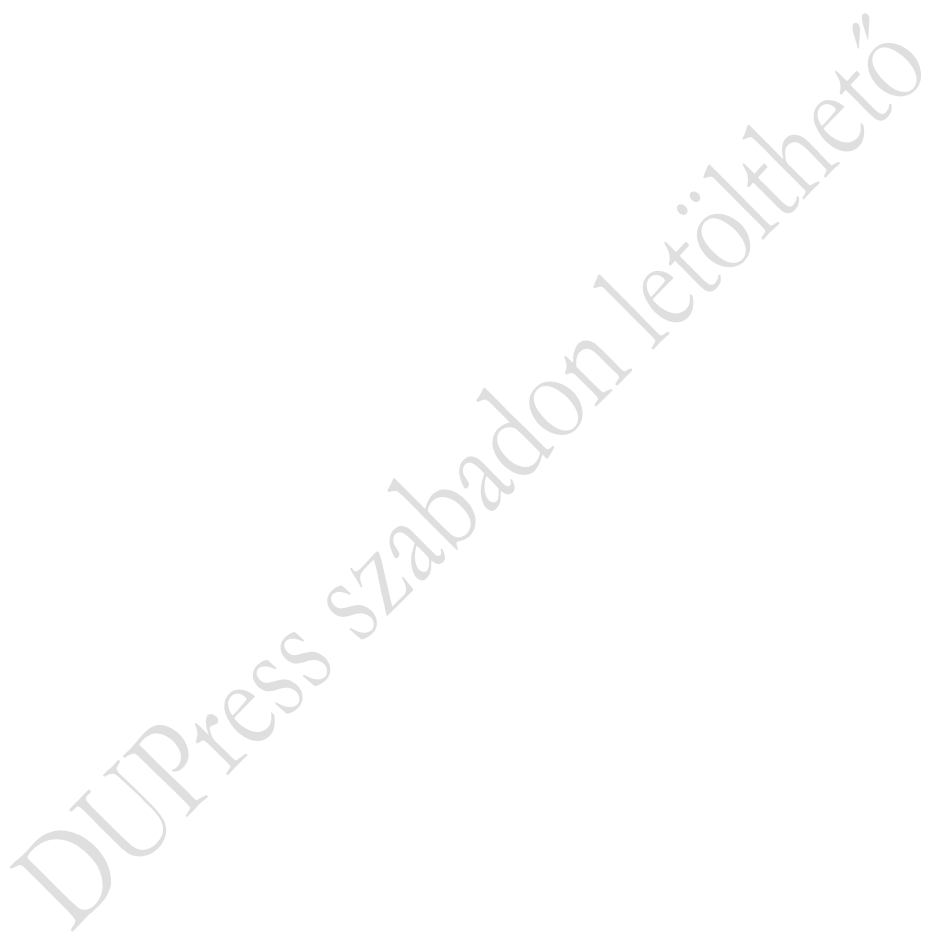




\title{
ÖNKORMÁNYZATOK ÉS HELYI KÖRNYEZETI POLITIKA - EGY EMPIRIKUS KUTATÁS EREDMÉNYEI
}

\author{
Fónai Mihály - Pénzes Ferenc*
}

Tanulmányunkban az önkormányzatok „helyi környezeti politikájára" ható aktorok szerepének az elemzésére vállalkozunk. A vizsgált időszak a magyar önkormányzati rendszer harmadik periódusa, melynek jellemző vonása a centralizált „helyi állam” modelljének az érvényesülése. Ez jelentősen alakítja az önkormányzati szerepeket a helyi környezeti politika területén is.

Megállapításainkat egy empirikus kutatás eredményeire alapozzuk, 515 települési önkormányzatnak a környezeti kérdésekben kompetens munkatársai válaszai alapján. A kutatás főbb eredményei azt mutatják, hogy a környezet ügye fontos az önkormányzatok számára, részben a jogi szabályozás, részben a pályázati kritériumok, és a helyi társadalom véleménye és elvárásai miatt, ám ettől függetlenül maga a megvalósuló „,környezeti politika” elsősorban egy, a már kialakult helyzetekre reflektáló politikát jelent. Kutatásunk sok szempontból tényfeltáró jellegü, így az eredmények elemzésében a leíró jelleg dominál.

\section{Az önkormányzati rendszer változásai}

Magyarországon az 1989-1990-es rendszerváltást követően három közigazgatási reformhullám söpört végig. Az elsőt (19891998) a szocializmus maradványaival szemben a demokratikus kormányzati berendezkedés kiépítésével és a piacgazdaságra való átállással összefüggő intézmények létrehozása jellemezte. A rendszerváltást követő erős intézményi decentralizációval és a

\footnotetext{
* Prof. Dr. Fónai Mihály, CSc, tanszékvezető egyetemi tanár; Dr. Pénzes Ferenc PhD, egyetemi adjunktus, DE-ÁJK, Közpolitikai és Alkalmazott Szociológiai Tanszék. A tanulmány a K 115530 ny. sz. kutatási projekt keretében, a Nemzeti Kutatási, Fejlesztési és Innovációs Hivatal támogatásával készült.
} 
központi hatalomtól független, autonóm önkormányzatokkal, a végrehajtó hatalom müködését nehezítő alkotmányos fékekkel és ellensúlyokkal, és az Országgyülés szerepének megerősítésével szemben az Antall-kormány a kormányzat egységesítését és hatalmi pozicionálását próbálta elérni. A tárcák részérdekei fölé emelte az „összkormányzati” érdekek érvényesítését, létrehozta a referatúrarendszert, a közigazgatási és politikai államtitkári értekezlet segítségével koordinálta a központi kormányzat tevékenységét, kialakította a Miniszterelnöki Hivatalt. ${ }^{1}$ A túlburjánzott országos hatáskörü főhivatali struktúra átalakítása, jogi státuszuk rendezése ekkor történt meg. ${ }^{2}$ Az 1990-ben elfogadott új önkormányzati törvény meglehetősen széles körű felelősséget bízott a helyi hatóságokra a feladatellátás tekintetében. Az infrastrukturális szolgáltatások - mint például az ivóvízellátás, a közvilágítás, a szilárd hulladékok kezelése, az utak és temetők fenntartása kizárólagosan önkormányzati feladatok lettek. Ezen túlmenően a nagyobb városok önkormányzatai a helyi tömegközlekedés, a szennyvízcsatornák, a távhőszolgáltatás ügyeit is intézték. Az önkormányzatok biztosították továbbá - természetesen méretüktől, anyagi teherbírásuktól függően - az óvodától a középiskoláig az oktatást-nevelést, az alapvető egészségügyi ellátást, az idősek gondozását. Az ilyen feladatmegosztást elóíró jogszabály biztosította a települések egyenlőségét is. A települések - szétaprózottságuk mellett - túl sok feladatot kaptak, és így azok ellátása rendkívül költségesnek bizonyult. A közmüszektor átalakulása is ekkor ment végbe. A korábbi állami közmücégeket előbb önkormányzati tulajdonba adták, majd a gazdasági társaságokról szóló törvény hatálya alá sorolták be azokat, s végül privatizálták majdnem mindegyiket. A személyes (humán és szociális) közszolgáltatások messzire ható decentralizációja is megtörtént: a civil szervezetek vették át a vezető szerepet a szociális ellátások biztosítása terén, majd ehhez kapcsolódtak az egyházak, a karitatív szervezetek. Az egyházak továbbá a középfokú, illetve az alapfokú iskolák fenntartásába is újra bekapcsolódtak. Ugyanakkor az állami és

\footnotetext{
1 Vesd össze: PEsTI Sándor: A kormányzati döntéshozatal. Századvég 2000/18, www.c3.hu/scripta/szazadveg/18/pesti.htm (2017. 01. 10.).

${ }^{2}$ A nem minisztériumi szintủ központi államigazgatási szervek jogállásának elveiről szóló 1040/1992. (VII. 29.) Korm. határozat, valamint az Országos hatáskörü szervek irányításáról és felügyeletéröl szóló 3333/1992. Korm. határozat révén.
} 
önkormányzati intézmények helyzete is alapvetően megváltozott a szektor-semleges finanszírozás és a piaci gyakorlatok elterjedésével. a '90-es évek közepére az állami törzsvagyon önkormányzati tulajdonba való átadása megtörtént, s amit ebböl privatizálni lehetett, azt az ezredfordulóig magánosították is. ${ }^{3}$ Ezen periódus második felében a rendszerváltás lelkesedésének csillapultával pedig megkezdődött az új rendszer anomáliáinak a kiigazítása. ${ }^{4}$

A második refomhullámban (1998-2010) két fó motívum fedezhető fel: először is az „európaizáció,” vagyis az intézmény- és szervezetrendszer hozzáigazítása az EU-s jogszabályokhoz, elvárásokhoz és mintákhoz, másodszor pedig a „prezidencializálódás,” a kormányzat és a kormányfö hatásköreinek kiterjesztése. Az intézményrendszer strukturális átalakítása sokkal látványosabb volt a területi és a helyi szinten, mint a központi államigazgatás szintjén. Ekkor alakult ki a régiók rendszere, ment végbe a decentralizáció és a dekoncentráció, hozták létre a kistérségi rendszert. 2006-ig, a második Gyurcsány-kormány beiktatásáig megfigyelhető a minisztériumi feladatok agency-jellegü szervezeteknek való kiszervezése, helyi szinten megerösödik a közfeladatok kiszerződésének gyakorlata, továbbá jelentősen megnövekszik az országos föhatóságok és a „kvázi-kormányzati szervezetek" száma. ${ }^{5} 2006$ után pedig megindul egy centralizációs folyamat, melynek része a miniszterelnök szerepének erősödése a kormányon belül; a Miniszterelnöki Hivatal (MEH) kormányzati struktúrán belüli uralkodó volta; a végrehajtó hatalmi ág elsőbbsége a törvényhozóval szemben; a kormányülések formálissá válása, jelentőségének csökkenése; a kormánypárti frakciókon belül a frakciófegyelem erősödése. Ebben a periódusban számolják fel a

\footnotetext{
${ }^{3}$ Horváth M., Tamás: From Municipalisation to Centralism: Changes to Local Public Delivery in Hungary. In: Wollmann et al. (eds.): Public and Social Service in Europe. Palgrave Macmillan UK, London, 2016, 185-199.

${ }^{4}$ KovÁCs Éva-HAJNAL György: A magyar központi államigazgatás változásai a rendszerváltástól 2015-ig. In: Jakab András-Gajduschek György (szerk.): A magyar jogrendszer állapota. MTA Társadalomtudományi Kutatóközpont, Jogtudományi Intézet. Budapest, 2016, 534-542.

${ }^{5}$ HAJNAL György: Adminisztratív politika a 2000-es évtizedben: Az ügynökség típusú államigazgatási szervek strukturális dinamikája 2002 és 2009 között. Politikatudományi Szemle 2011/3, 54-74.; illetve PÉNZES Ferenc: A közfeladatok megoldásának külön útjai. Jogtudományi Közlöny 2015/9, 449-451.
} 
közigazgatási államtitkári értekezletet (KÁT), s ezzel együtt növelik a politikai irányítást és felügyeletet. ${ }^{6}$

A harmadik periódust (2010-2016) az ,illiberális” fordulat, a túlzott közigazgatási centralizáció, valamint a kormányzati túlhatalom jellemzi. ${ }^{7} 2015$. február végéig a kormányzó koalíciónak kétharmados többsége volt az országgyülésben. Az alkotmányos berendezkedést, a politikai rendszert - $\mathrm{s}$ ezen belül a kormányzati intézményrendszert - átfogóan és rendkívüli mértékben átalakították. A miniszterelnök szerepe tovább erösödött, illetve ezzel párhuzamosan megnövekedett közvetlen apparátusának a hatásköre is. Alapvetően átrajzolták a központi államigazgatás szervezetrendszerét. A korábbi tizenhárom minisztérium helyére mindössze nyolc integrált csúcsminisztériumot szerveztek. Visszaállították a közigazgatási államtitkári pozíciót és a közigazgatási államtitkári értekezletet (KÁT). A Miniszterelnöki Hivatalt pro forma megszüntették, de valójában inkább megkettőzték. Létrehozták a Miniszterelnökséget, amely a miniszterelnök közvetlen munkaszervezeteként és a politikai egyeztetések fórumaként müködött/müködik, míg a közigazgatási koordináció feladatait a Közigazgatási és Igazságügyi Minisztérium látta el. ${ }^{8}$ Ezt fejelték meg a Miniszterelnöki Kabinetirodával, ami a kormányfö programjait szervezö, a kormányzati kommunikációt irányító, 2015 októberében létrehozott minisztérium, amelynek élén miniszteri rangban a miniszterelnök kabinetfönöke áll. ${ }^{9}$ Az országos főhatóságok számának és viszonylagos önállóságának csökkenése mellett az Alaptörvény 2011-től egy új kategóriát is nevesít: az ún. önálló szabályozó szervet. Ezt az Országgyülés hozhatja létre, de csak sarkalatos törvénnyel.

\footnotetext{
${ }^{6}$ KOVÁCS-HAJNAL: i.m., 542-550.

${ }^{7}$ Az illiberális demokrácia fogalma Magyarországon Orbán Viktor 2014. július 25-én Tusnádfürdőn elmondott beszéde kapcsán került a figyelem középpontjába. A kormányfő azokról a világban létező illiberális demokráciákról beszélt, amelyek nem nyugatiak, nem liberálisok és talán nem is demokráciák, ugyanakkor mégis sikeresek, és a politológia elemzések „sztárjai:” Szingapúr, Kína, India, Oroszország, Törökország. A beszédet lásd: http://mno.hu/tusvanyos/orban-viktor-teljes-beszede1239645 (2017. 01. 10.). Továbbá vö. KovÁCS-HAJNAL: i.m., 550-559.; HORVÁTH i.m., 192-196.

${ }^{8}$ KovÁCS-HAJNAL: i.m., $550-561$.

9 Létrejött a Miniszterelnöki Kabinetiroda. http://mno.hu/politika/letrejott-aminiszterelnoki-kabinetiroda-1308775 (2017. 01. 10.).
} 
Ez utóbbi időszakban a területi kormányzás rendszerében az önkormányzatok rovására a területi államigazgatás erősödött meg. A kormányhivatali rendszer kialakítása kapcsán meg kell említsük, hogy a 2012. évi XCIII. tv. rendelkezett a járások kialakításáról. Ennek az alsó-közép szintnek a létrehozása érintette/érinti leginkább az önkormányzatokat. A kormányzati cél ezzel az önkormányzati és az államigazgatási feladatok szervezeti szinten történő elválasztása volt. Az államigazgatási feladat- és hatáskörök területi alsóközépszinthez történő telepítésénél a jogalkotó által alkalmazott rendezőelv szerint a helyismerethez kötődő, mérlegelési jogkörbe tartozó, azonnali reagálást igénylö ügyek, valamint az önkormányzat képviselö-testületének rendeletalkotási jogkörével összefüggő jegyzői hatáskörök az államigazgatás helyi szervénél, a jegyzőnél maradtak, míg az állami feladatatok a járási hivatalokhoz kerültek. Vizsgálódásunk szempontjából például továbbra is a jegyző kompetenciájába tartoznak - a teljesség igénye nélkül - a környezetvédelmi hatósági jogkör gyakorlására, a közterületen álló fás szárú növények kivágásának, pótlásának engedélyezésére vonatkozó feladatok. Ugyanakkor a kormányhivatali átszervezés sajátosságaként szünt meg - szinte teljes mértékben, ti. a kormányhivatalba integrált szervek viszonyában - a szakhatósági rendszer. Az alapügyben eljáró államigazgatási szerv más hatóság közremüködését így nem önálló eljárásban, hanem véleményezőként veszi igénybe. Ez azért van így az új rendszerben, mert a két szervezeti egység egy szervezet része. Ennek következménye azonban az, hogy az ügyfél számára az önálló jogorvoslat lehetősége megszünik, illetve az is, hogy a társadalmi szervek, civil szervezetek önálló fellépési lehetősége csökken. Az ügymenet ilyeténképpeni gyorsitása révén azonban a jogszerüség és a jogvédelmi garanciák csorbulnak. Különösen ekként jelentkezik ez az ellenhatás a környezetvédelmi igazgatás területein. ${ }^{10}$

Az önkormányzatok esetében így joggal beszélhetünk modellváltásról az elmúlt öt és fél év tekintetében. A korábbi önkormányzati dominanciájú területi kormányzást a centralizált (dekoncentrált) „helyi állam” modellje váltotta fel. Az

\footnotetext{
${ }^{10}$ HORVÁTH M. Tamás-JÓzSA Zoltán: Az államigazgatás helyi és területi szervei. In: Jakab András-Gajduschek György (szerk.): A magyar jogrendszer állapota. MTA Társadalomtudományi Kutatóközpont, Jogtudományi Intézet, Budapest, 2016, 564582.
} 
önkormányzatok helyébe esetenként gigantikus méretü állami hivatalok (megyei és járási kormányhivatal) léptek, amelyek nem feltétlenül képesek rugalmas, polgár-közeli és fogyasztóbarát teljesítményre. A korábbi modellben az önkormányzatokhoz telepített feladatköröket javarészt ezekhez a hivatalokhoz delegálták, s egyedül a helyi gazdaságfejlesztés terén kaptak plusz lehetőséget a települések. Így az önkormányzatok mára kiestek a hatalommegosztásban korábban betöltött szerepükből, s egyre kevésbé képeznek ellensúlyt a központi irányítási szinttel szemben. ${ }^{11}$ Mindezek fényében jelen tanulmányunkban azt várjuk, hogy a „helyi állam" modellje hatást gyakorol az önkormányzati döntések mechanizmusára is.

\section{A kutatás során alkalmazott módszerek}

Az önkormányzatok körében folytatott kutatás egy induktív logikájú kutatás felépítését követte, ahol az egyes lépések, megközelítésmódok és módszerek eredményei egymásra épülnek, a következő lépések tervezéséhez a megelőzők tapasztalatait figyelembe lehet venni. Mivel a kutatás célja a vizsgált terület (a települési önkormányzatok szerepe a környezetvédelemben) változásaihoz kapcsolódik, az induktív logika módot ad arra, hogy a „leíró, feltáró” kutatási fázisokat „magyarázó” fázisok kövessék, majd a kutatás végére a magyarázó modellek kialakítása mellett mód nyílik környezetjogi, szakmai, tudományos javaslatok megfogalmazására is, például a helyi problémakezelési mechanizmusokat illetően.

E megközelítésmód alapján a kutatás során többféle módszert alkalmaztunk, illetve alkalmazunk. A kutatás fókuszát a települési önkormányzatok jelentik. Kutatási tervünk az volt, hogy 300 önkormányzat körében folytatunk kérdőíves vizsgálatot, közülük 12ben fókuszcsoportos interjút. Jelen állapot szerint a kérdőíves kutatást lezártuk, a fókuszcsoportos interjúk pedig folyamatban vannak. Azokon a településeken, ahol fókuszcsoportos interjúkat vettünk fel, a rendelkezésre álló települési dokumentumok, stratégiák

${ }^{11}$ PÁlNÉ KovÁCS Ilona: Modellváltás a magyar önkormányzati rendszerben. In: JAKAB András-GAJDUSCHEK György (szerk.): A magyar jogrendszer állapota, MTA Társadalomtudományi Kutatóközpont, Jogtudományi Intézet, Budapest, 2016, 583599. 
és szabályozás alapján egy települési előtanulmány készült, amely elsősorban a helyi szabályozási mechanizmusokat, és magát a helyi jogi szabályozás anyagát elemzi. A kérdőíves adatfelvétel, a jogi fókuszú előtanulmányok és a települési terepkutatás alapján e 12 településről „esettanulmányt” készítünk (jelenleg két teljes esettanulmány már elkészült).

A „helyi környezetpolitika” aktorai közül a civil szervezeteket vonjuk be, e körben is több fókuszcsoportos interjú már elkészült. ${ }^{12}$

\section{A kérdő́ves kutatás mintája és a kutatás dimenziói}

A kutatási projekt tervezésekor 300 önkormányzat megkeresését tüztük ki célul. A kutatás alapsokaságát 3177 települési önkormányzat jelentette. Többféle mintaválasztási elv közül a kvótás mintaválasztást alkalmaztuk. Ennek oka, hogy ha a különböző jogállású települések közül véletlen mintaválasztással hozunk létre mintát, a nagyobb lélekszámú települések és a budapesti kerületek a téma szempontjából való fontosságukhoz képest kevésbé kerültek volna be a mintába. Emiatt valamennyi megyei várost és budapesti kerületet bevontuk a mintába, majd a városok és a községek csoportjából választottunk mintát.

A kérdöívet a fókuszcsoportos interjúk tapasztalatai alapján szerkesztettük, azokat a települések leginkább érintett tisztségviselöi, például a jegyzők, vagy a területtel hivatalból foglalkozó, más munkatársak töltötték ki. A lekérdezésre két hullámban került sor, az alkalmazott módszer call centeres támogatású on-line kérdőív volt. Ez lehetőséget adott arra, hogy az eredetileg tervezett 300-as minta elemszámát felemeljük, s így végül 516 települési önkormányzati kérdőív áll rendelkezésünkre (19 fővárosi kerület, 15 megyeszékhely, illetve megyei jogú város, 187 város, és 295 község). Ebben a tanulmányban a nem súlyozott alapmegoszlásokat ismertetjük (a továbbiakban több független változó alapján oksági elemzéseket is végzünk majd a súlyozott mintán). $\mathrm{Az}$ alapmegoszlások ismertetése miatt tanulmányunk leíró jellegü.

A kérdőíves kutatás dimenziói a következők voltak:

\footnotetext{
${ }^{12}$ Kutatási hipotéziseink, módszereink, kiválasztási szempontjaink bemutatására ld. FODOR László-BARTA Attila-FóNAI Mihály-BÁNYAI Orsolya: Települési környezetvédelem Magyarországon: Egy kutatás előfeltevései. Tér és Társadalom 2016/3, 19-39.
} 
- Jogszabályi környezet és jogértelmezés

- Helyi rendeletalkotás, döntéshozatali mechanizmus

- Külső és belső kapcsolatok, önkormányzati bizottságok, szakemberek

- Környezeti problémák és jogviták, környezeti konfliktusok kezelése

- Beruházások, beszerzések és környezeti szempontok

- Helyi eszközök és lehetőségek

\section{A kérdőíves kutatás főbb eredményei}

Az önkormányzatok körében folytatott kérdöíves kutatás eredményeit a kutatás, illetve a kérdőív dimenziói alapján mutatjuk be. Tanulmányunk, ahogy arra a bevezetésben is utaltunk, leíró jellegü, az alapmegoszlásokat ismertetjük, és az azokból levonható főbb következtetéseket fogalmazzuk meg (további tanulmányainkban természetesen az oksági összefüggések magyarázatát is elvégezzük).

Elsőként vizsgáljuk meg, hogy milyen intézményi, szakmai lehetőségei vannak az önkormányzatoknak, illetve milyen szervezeti megoldásokat alkalmaznak a környezeti kérdések kezelésére (1. ábra).

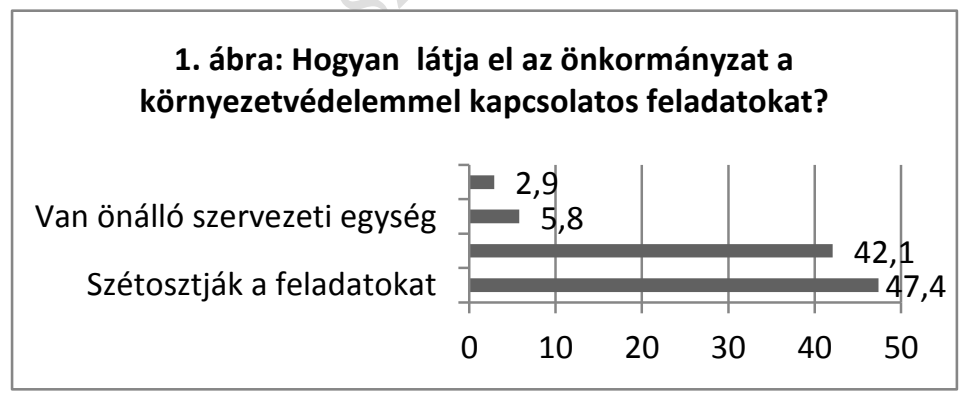

A tipikusnak az mondható, hogy az önkormányzatok a környezetvédelemmel kapcsolatos feladatokat szétosztják, hisz 5,8\%-uk esetében van csak önálló szervezeti egység, mely szakosodva foglalkozik környezetvédelmi kérdésekkel. Ezzel is összefügghet, hogy csak az önkormányzatok 8,5\%-nak van 
környezetvédelmi szakbizottsága, 27,4\%-uk esetében más bizottság látja el ezeket a feladatokat, a többi esetben ad hoc megoldást választanak. Ugyanakkor az önkormányzatok fele müködik együtt a hatósági feladatok ellátása terén a területi környezetvédelmi hatósággal, és 39,6\%-uk nemzeti parki igazgatósággal. Az átalakult intézményrendszerben a területi környezetvédelmi hatósággal az önkormányzatok együttmüködése alapvetően nem változott $(81,6 \%)$, egytizedük javulásról, egyhuszaduk a kapcsolat romlásáról számolt be. Ez azt is jelentheti, hogy az intézményrendszer átalakulása mellett és közben a kapcsolatok valószínüleg a kialakult személyes és ügy-centrikus csatornákban maradtak, azaz az önkormányzatok gyorsan adaptálták a környezeti ügyek intézésének új intézményi metódusait. Ennek egyik lehetséges esete, ha az önkormányzat valamilyen szakismeretet igénylő szolgáltatást vesz igénybe külső szervezettől (2. ábra).

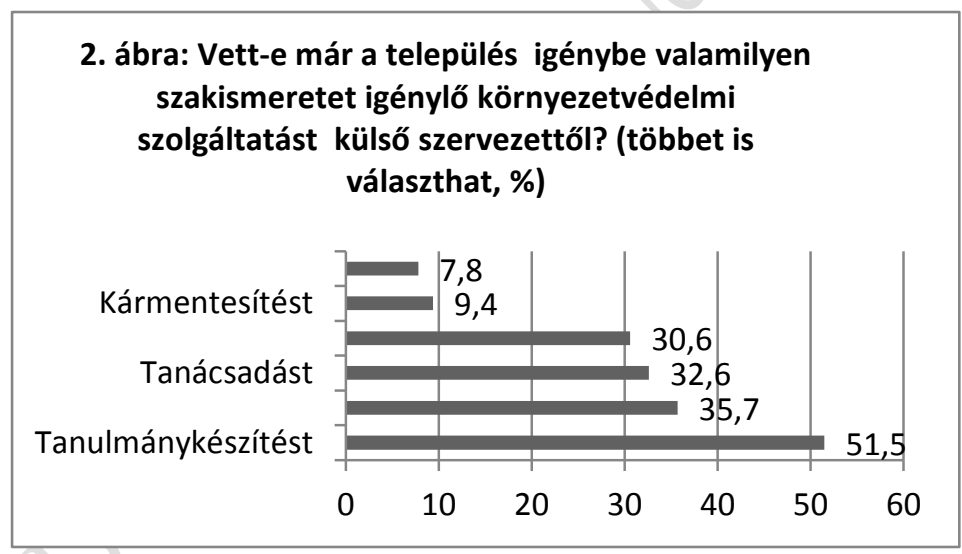

Az igénybe vett szolgáltatás legjellemzőbben tanulmánykészítés valamilyen környezeti kérdésről, emellett ez a tevékenység kapcsolódhat pályázatíráshoz is. Jelentős még a tervezési szolgáltatás, a tanácsadás és a pályázatírás megrendelése külső szervezettől. Mindezek alapján a települési önkormányzatok helyi környezeti „,politikájának” és szabályozásának adottak a szervezeti és szakmai feltételei, igaz, a települések a saját szakmai (szervezeti) hiányosságaik következtében külső szervezetekhez fordulnak (látni 
fogjuk, hogy jogértelmezési problémák esetében a kormányhivatalokat keresik az önkormányzatok, egyúttal a települések mérete és jogállása is hatást gyakorol a helyi környezeti politikára és annak lehetőségeire).

A központi környezetvédelmi/környezeti jogszabályok alkalmazása során csak a települések 30,2\%-a jelezte azt, hogy még nem fordult elő ilyen probléma, kétharmada $(67,4 \%)$ válaszolta azt, hogy egyes esetekben előfordulhat jogértelmezési probléma, és elhanyagolható $(1,8 \%)$ azoknak a településeknek az aránya, amelyek minden esetben problémaként szembesülnek a jogalkalmazással. Lássuk, melyek a tipikusan előforduló problémák (3. ábra).

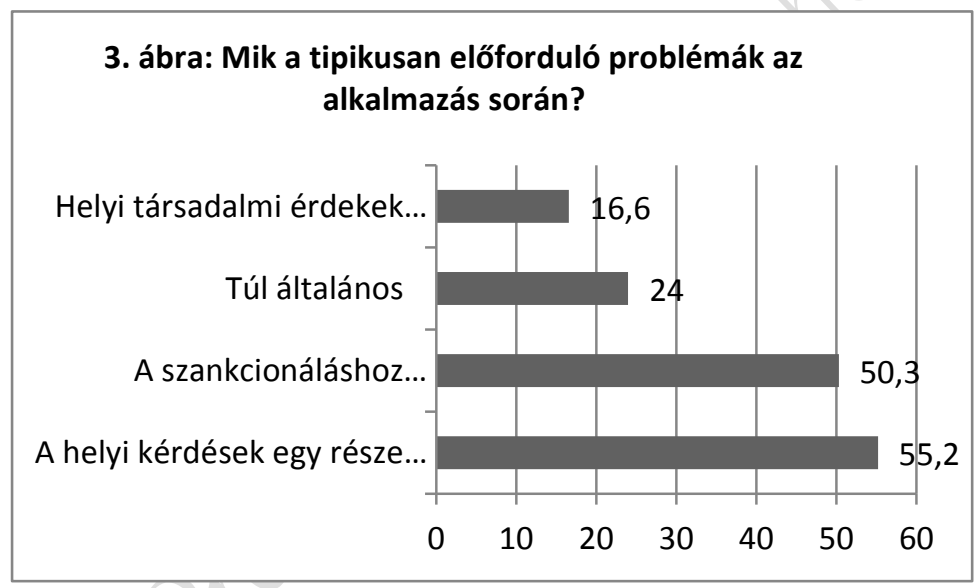

Legjellemzőbb, hogy a központi szabályozás alapján a helyi kérdések egy része nem kezelhető, ami összefügg azzal is, hogy a szabályozás túl általános. $\mathrm{Az}$ is nehezíti az önkormányzatok munkáját, hogy nem állnak rendelkezésükre a szükséges szankcionáláshoz eszközök (erre a módosítási javaslatok között is utalnak). Látszólag kevésbé jelentős, mégis fontos, hogy a központi szabályozás miatt helyi érdekek is sérülhetnek. Az erre vonatkozó kérdés ,igen” válaszai (sérült-e a központi elöírások változásai miatt valamilyen helyi/önkormányzati érdek) alapján a települések 13,3\%a érzékelt ilyen esetet (ez közel áll a 3. ábrán feltételes módban megfogalmazott helyi érdek sérülés esélyéhez). Ilyen esetben, ahogy 
arra utaltunk, a kormányhivatalokhoz fordulnak leginkább a települési önkormányzatok (4. ábra).

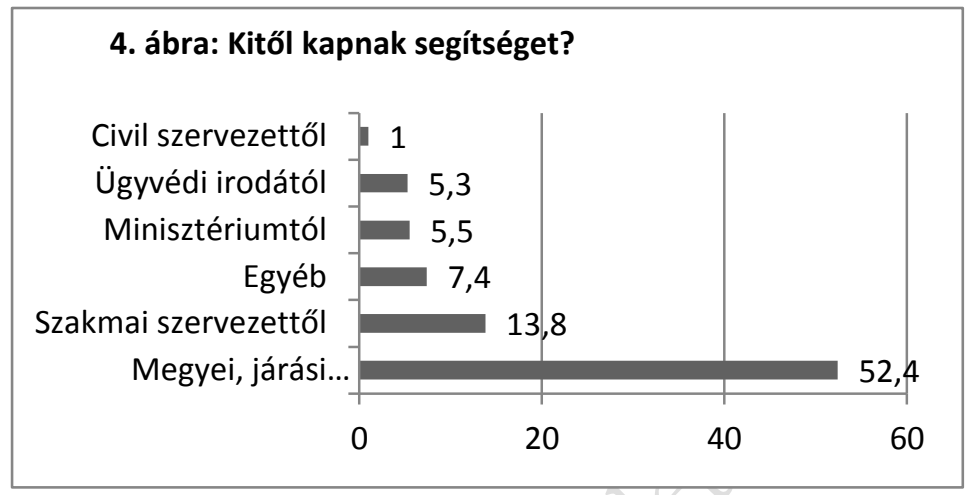

A szakmai szervezetektől kért és kapott segítség ebben az esetben a jogértelmezésre vonatkozik, hisz láttuk (2. ábra), a települések meghatározó része fordul egyébként külső szervezethez (tanulmányírás, tervezés, tanácsadás, pályázatírás). Nem jellemző, hogy az önkormányzatok ügyvédi irodákhoz fordulnának, és teljesen elhanyagolható a civil szervezetek szerepe ebben az esetben. A válaszok azt mutatják, hogy az átalakult államigazgatási és önkormányzati modellben az önkormányzatok a kormányhivatalokhoz fordulnak problémás esetekben - ez részben korábban is így volt, a megyei önkormányzatok erőteljesebb szerepe miatt. A regnáló struktúra a kormányhivatalok szerepének az erősödését mutatja, és ezt igazolják a kérdésre adott válaszok is.

Maga a helyi rendeletalkotás és döntéshozatali mechanizmus azonban azt mutatja, hogy a korábbi évtizedekben kialakult metódusok élnek tovább, bár például a törvény szövegének a minimális változtatása viszonylag kis súllyal esik latba az opciók között (5. ábra). 


\section{5. ábra: Hogyan alkalmazkodnak a változó jogszabályi környezethez?}

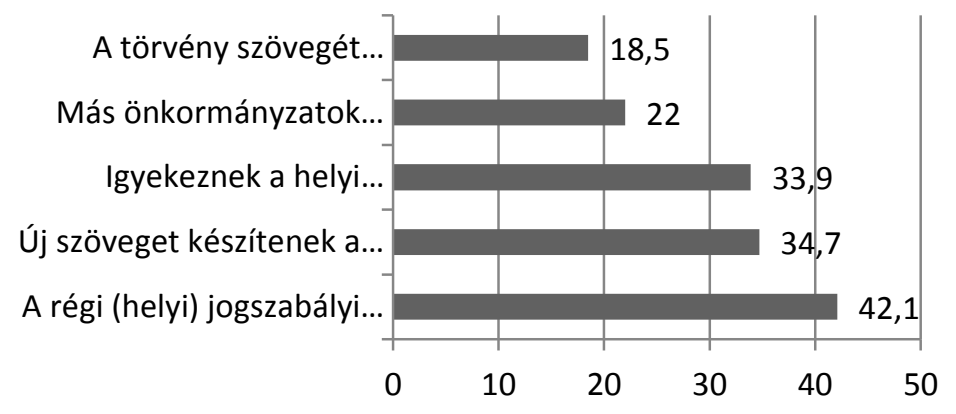

Legjellemzőbb az, hogy a változó jogszabályokat a korábbi, helyi jogszabályi szövegbe szerkesztik bele. Nagyon fontos, és a helyi sajátosságok, feltételek és érdekek érvényesítésének a szándékát mutatja, hogy az önkormányzatok egyharmada - egyharmada e tényezöket is figyelembe veszi. Ugyanakkor a „kopizás” sem elhanyagolható - a törvény szövegének a minimális változtatása mellett - ez más önkormányzatok hasonló szövegeinek, megoldásainak ,átvételét” jelenti. A két kérdésblokkra (4. és 5. ábra) adott válaszok azt mutatják, hogy a helyi rendeletalkotásnál a települési önkormányzatok figyelembe veszik a helyi társadalom sajátosságait és érdekeit, ám ha a központi jogszabályi változások problémákat generálnak, az átalakult köz- (és állam-) igazgatás működési módjából következően a kormányhivatalokhoz fordulnak.

A helyi rendeletalkotás és stratégiaalkotás során egyébként a települési önkormányzatok $38 \%$-a végzett környezeti hatásvizsgálatot, és amely település folytatott ilyen tevékenységet, azok annak az eredményeit figyelembe is veszik. Önkormányzati döntésekből a települések 8,8\%-nak származott valamilyen helyi konfliktusa. Látható, hogy környezeti ügyekben a helyi szabályozásban a települési önkormányzatok arra törekszenek, hogy figyelembe vegyék a helyi társadalom szempontjait és a környezet állapotát; kérdés, milyennek látják az önkormányzatok helyi környezeti „politikáját,” és annak megvalósulását a saját településükön (6. ábra). 


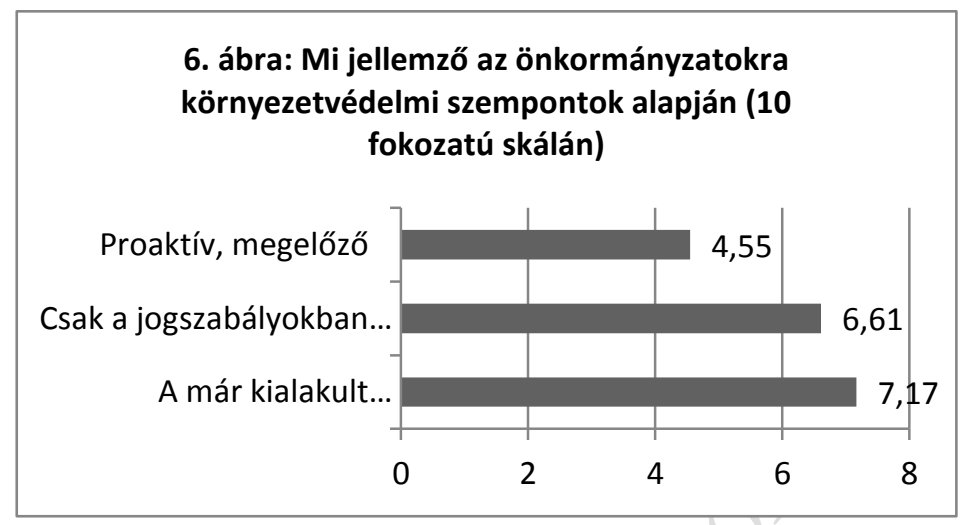

Bár a helyi szabályozásban a helyi társadalom érdekét fontosnak tartották a megkeresett önkormányzatok (lásd az 5. ábrát), maga a „napi," tényleges környezetvédelmi, környezeti tevékenység (helyi környezeti politika és szabályozás) esetében sokkal inkább egy követö, a problémákat utólag megoldó gyakorlat (ami stratégiának kevésbé nevezhető) körvonalazódik, amire a jogszabályi kényszerek is nagyobb hatást gyakorolnak, mint a megelőzés. Ennek számos oka lehet, így például a rendelkezésre álló szakmai stáb, vagy a feladathoz rendelhetö finanszírozás hiánya, esetleg szükös volta, a település mérete, a meglévő környezeti problémák, stb. Ezektől függetlenül is látható azonban, hogy a települési önkormányzatok inkább az események után mennek, és kevésbé képesek a proaktív stratégiára. Ezt támasztja alá, hogy a megkérdezett önkormányzati szakembereknek a 9,6\%-a tartotta saját önkormányzatát proaktívnak, a kialakult problémákat megoldónak 17,7\%-a, és jogszabályi feladatot végrehajtónak 19,5\%-a - fele (49,5\%) pedig a konkrét helyzet alapján választ opciót a három lehetséges reakció közül. A felemás helyzetet jól mutatja, ahogy a környezeti kérdésekben „ideális" és ,jellemző" önkormányzati magatartást osztályozták a megkérdezettek a döntéshozatali mechanizmusban (7. ábra). 


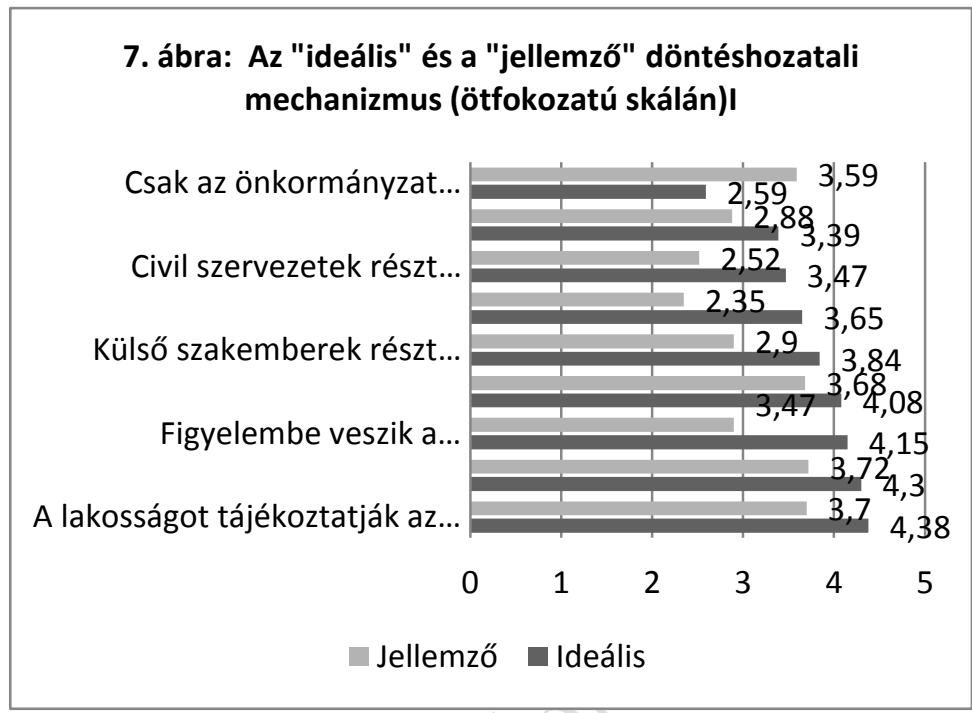

Az ,ideális” és a ,jellemző" döntéshozatali mechanizmus lényegesen eltér egymástól, ami valószínü, hogy nemcsak környezeti kérdésekben figyelhető meg a települési önkormányzatoknál. Az „ideális” döntéshozatali mechanizmust a lakosság bevonása és tájékoztatása, a szakemberek és a szakhatóságok, a szakmai és tudományos szervezetek, és a civilek bevonása jellemezné, figyelembe véve még a vállalkozói érdekeket is. Ehhez képest a „jellemzö" döntéshozatali mechanizmus sokkal kevésbé ilyen sokszereplős, és abban sokkal kisebb mértékben jelennek meg a helyi társadalom (benne a vállalkozók) elvárásai és érdekei. A jellemző döntéshozatali mechanizmus az, hogy az önkormányzat bizottságának és a képviselötestületnek, az önkormányzat szakembereinek és a zöldhatóságnak a bevonásával történik a döntések meghozatala, a lakossági szempontok és érdekek mérsékeltebb figyelembevételével. Ebben a folyamatban az ideálishoz képest a civilek, szakmai és tudományos szervezetek, szakemberek szorulnak háttérbe. Mindez azt is jelenti, hogy a „helyi környezeti politika" aktorai között az önkormányzat a legmeghatározóbb, amellett, hogy a lakossági véleményekre és 
elvárásokra is figyelnie kell, ugyanakkor ezt a helyi politikát a szakmai és civil szervezetek, mint potenciális aktorok, alig alakítják.

Összességében a települési önkormányzatok egy inkább követő és jogszabályalkalmazó helyi „környezetpolitikát” érvényesítenek, melyben a meghatározó aktor az önkormányzat, amire valamelyest hat a helyi társadalom, és sokkal kevésbé a szakmai szervezetek (miközben azokat több területen is megkeresik és megbízzák az önkormányzatok). A kormányhivatalok (és szakhatóságok) ebben a mechanizmusban részben a döntés elökészítésben, részben a törvényességi felügyeletben és jogszabály alkalmazási problémák esetében a törvényességi felügyelethez kapcsolódó potenciális „tanácsadásban” játszanak szerepet.

Ezt a helyzetet jól illusztrálja a környezetvédelmi beruházások helyzete (8. és 9. ábra). A környezetvédelmi beruházások megléte vagy hiánya már önmagában is mutatja, hogy mennyire jelenik meg a környezetvédelem a helyi politikában (a miérteket most nem vizsgálva, pl. proaktív módon, vagy kényszerre, nyomásra), illetve azt is, hogy milyen aktorok gyakorolnak arra hatást.

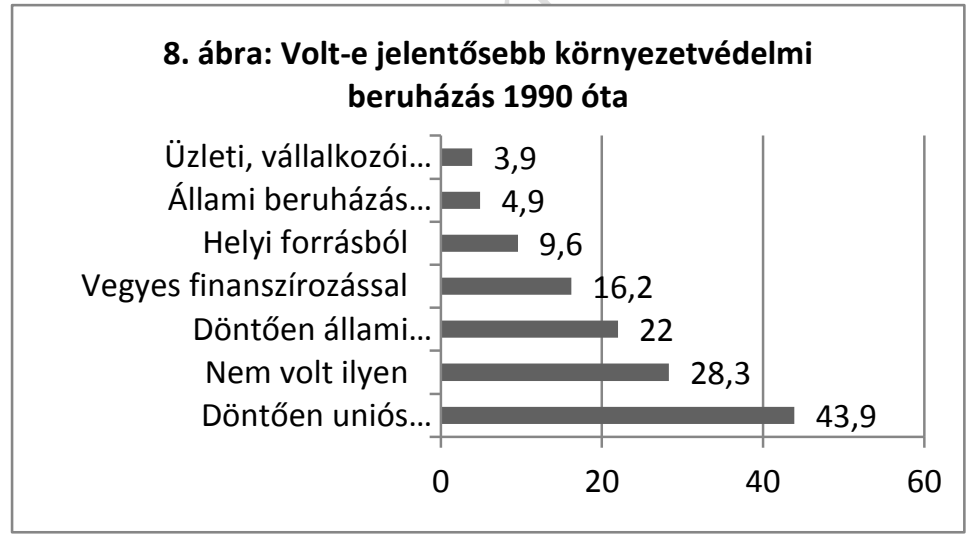

Valamilyen jellegü, típusú „környezetvédelmi, környezeti” beruházás (értelmezési kérdés is, hogy mit tekintenek annak) 1990 óta a települések többségében volt - a településeknek csak $28,3 \%$-a válaszolt úgy, hogy nem folytattak ilyen tevékenységet. Legjellemzőbb az, hogy a beruházásokat uniós támogatásból, illetve állami finanszírozással valósították meg, a helyi források aránya 
mérsékelt, és szinte elhanyagolható az üzleti szektor szerepe. E beruházások során a válaszok alapján az a jellemző, hogy az önkormányzatok figyelnek a környezeti szempontokra (9. ábra).

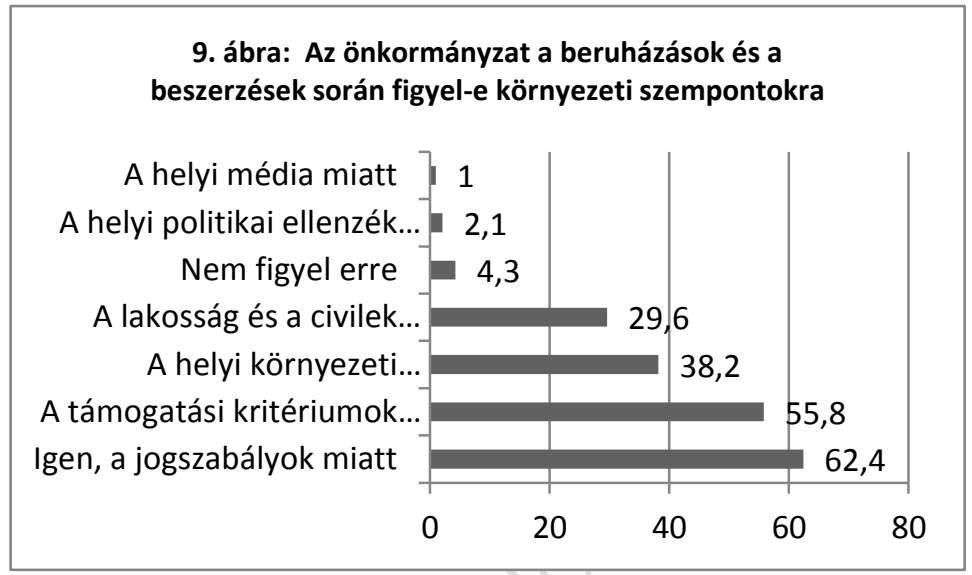

Ugyanakkor a környezeti szempontok érvényesítésére is igaz az, ami a döntéshozatali mechanizmusra, azaz külső tényezők, például jogszabály, vagy a pályázati kritériumok játszanak meghatározó szerepet. Részben ide sorolhatjuk a helyi környezeti stratégiát is, bár az összefoglalhatja a „,helyi környezeti politika” céljait, a különböző aktorok véleményét, elvárásait, és a környezet állapotából következő feladatokat is, nem csupán a magasabb szintü jogszabály/program alkalmazását jelentheti. Jelentősnek mondható a lakosság és a civilek véleményének a figyelembe vétele is, ám a helyi média (a vélemények alapján) nem alakító aktora a „helyi környezeti politikának."

Utaltunk már rá, hogy az önkormányzatok viszonylag eszköztelennek látják magukat a környezeti kérdések kezelésében, ezt mutatják a 10. ábra rangsor értékei is. 


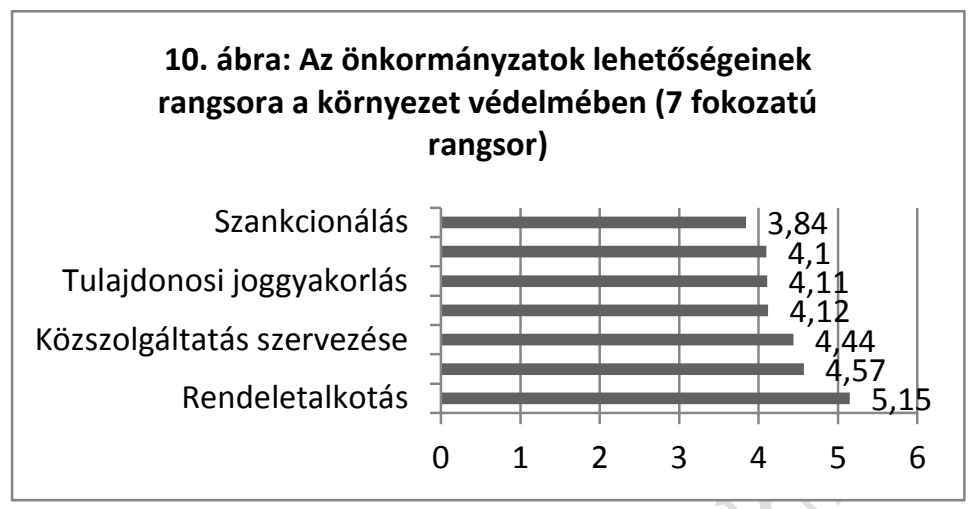

A válaszoló önkormányzati tisztviselők leginkább a rendeletalkotást emelik ki lehetséges eszközként, és viszonylag jelentősnek tartják az ellenőrzést és a közszolgáltatások szervezését is, átlagos súlyúnak értékelve a stratégiaalkotást, a tulajdonosi jogok gyakorlását és az engedélyezést, és csekély mértékünek a szankcionálás lehetőségét. E rangsor azt mutatja, hogy a települési önkormányzatok leginkább a rendeletalkotásban bíznak, bár az ahhoz kapcsolódó szankcionálás mérsékelt lehetősége gyengíti a rendeletek érvényesíthetőségét.

\section{5. Összegzés}

Tanulmányunkban 516 települési önkormányzat „helyi környezeti politikáját," és az arra ható tényezöket vizsgáltuk. Azt vártuk, hogy a magyar önkormányzati rendszer és az államigazgatás közelmúltbeli átalakulása már érzékelhető lesz a települési önkormányzatok müködésében a vizsgált területen is. $\mathrm{E}$ várakozásunk igazolódott, hisz az önkormányzatok a saját szabályozásukat és a központi jogszabályok alkalmazása során felmerülő problémákat a kormányhivatalokkal együttmüködve kezelik.

Ez azonban nem jelenti azt, hogy más aktoroknak ne tulajdonítanának szerepet, illetve azok ne tudnák a szempontjaikat és az érdekeiket érvényesíteni. Úgy tünik, leginkább a lakosság, a helyi társadalom az, ami nem megkerülhető ezekben a kérdésekben, hisz az ő „bőrükre” megy a játék, ha a környezeti problémákat nem 
kezelik. A válaszok alapján úgy tűnik, a vállalkozói szektor kevésbé képes hatást gyakorolni az önkormányzatokra e kérdésekben. Ellentmondásos a szakmai szervezetek és szakemberek hatása és megítélése, miközben fontos partnerként kezelik őket (például a hatástanulmányok készítésében, vagy pályázatok írásában), magára a döntési folyamatra kisebb a hatásuk. Az önkormányzati tisztviselök véleménye alapján legkevésbé a civil szervezetek és a helyi média képes alakítani a helyi környezeti politikát. 


\title{
HELYI STRATÉGIÁK ÉS \\ KÖRNYEZETVÉDELEM
}

\author{
Bányai Orsolya*
}

A települési önkormányzatok környezetvédelemben betöltött szerepe, lehetőségei jogtudományi nézőpontból nincsenek feltárva. $\mathrm{Az}$ alábbiakban ennek a fehér foltnak a csökkentéséhez járulnék hozzá azzal, hogy a települési önkormányzatok környezetvédelem terén rendelkezésre álló eszközei közül a stratégiaalkotást állítom fókuszba. ${ }^{1}$ A stratégiáknak nincs jogi kötőerejük, nem jogszabályi formában jelennek meg, és csak igen ritkán (pl. vízgyüjtőgazdálkodási tervek esetében) tartalmaznak konkrét, közvetlenül számonkérhető rendelkezéseket. Mégis kulcsfontosságúak, tekintve, hogy bármilyen területről, kérdésről legyen is szó (közlekedés, településfejlesztés, költségvetés, stb.) a rövid, közép, de leginkább hosszú távú stratégiaalkotás elkerülhetetlen, ha az adott ország, település nem egyik napról a másikra élve, a problémákat szüklátókörüen kezelve, hanem tudatosan, a problémákat rendszerszinten értelmezve akar fejlödni. Különösen igaz ez a környezet védelmére, a település fenntartható fejlödésének biztosítására, vagy ha arról van szó, hogy a település helyi szinten hogyan akar hozzájárulni az éghajlatváltozás hatásainak enyhítéséhez, illetve miként képzeli el az klímaváltozás által előidézett új viszonyokhoz történő alkalmazkodást. A stratégiákra a gyakorló jogászok részéről vélhetően nem jut figyelem. Ez érthető is,

\footnotetext{
* Dr. Bányai Orsolya, PhD, egyetemi adjunktus, Debreceni Egyetem Állam- és Jogtudományi Kar, Agrárjogi, Környezetjogi és Munkajogi Tanszék. banyai.orsolya@law.unideb.hu. A tanulmány a Nemzeti Kutatási, Fejlesztési és Innovációs Hivatal támogatásával, a K 115530 ny. sz. „Helyi önkormányzati szerepek és eszközök az ökológiai fenntarthatóság megvalósításában” c. projekt keretében készült.

${ }^{1}$ ANTAL Attila: Környezetpolitikai tervezés és stratégiaalkotás helyi szinten. In: Kákai László (szerk.): 20 évesek az önkormányzatok. Születésnap vagy halotti tor? IDResearch-Publikon, Pécs, 2010, 395-410.
} 
hiszen a gyakorló jogászok „csak” a jogszabályokat alkalmazzák, esetleg számításba veszik a különböző bírói gyakorlatokat, elvi iránymutatásokat. Elméleti oldalról azonban a stratégiák nem egyszerüen politikai kérdések. Azáltal, hogy a tartalmuk új jogi szabályozást hívhat életre, vagy a meglévő szabályozási környezet fejlesztésének igényét vethetik fel, olyan dokumentumokká alakulnak, amelyek a jogtudomány nézőpontjából is figyelemre érdemesek. Több esetben jogszabály maga írja elő a stratégiaalkotási kötelezettséget. Ennélfogva azt is vizsgálni lehet, hogy vajon ezek az elöírások megfelelöek-e, illetve a tervet/programot alkotó települések megfelelően hajtják-e végre az erre vonatkozó elö́rásokat. Ilyen fajta kötelezettséggel találkozhatunk például a környezetvédelmi programok tekintetében is. Ugyanakkor a környezetvédelem igen összetett ügy, és nemcsak a szük értelemben vett környezetvédelmi programokban jelenhet meg. Számos más, olyan helyi stratégia is létezik(-het), amelyik úgy befolyásolja közvetlenül a település környezetvédelmi tevékenységét, hogy nevében (címe szerint) nem klasszikus környezetvédelmi program. Ilyen lehet egy helyi fenntartható fejlődési stratégia, klímaváltozási stratégia, energiastratégia, integrált településfejlesztési stratégia, közlekedésfejlesztési stratégia, vagy olyan speciális tárgyúak, mint a füstköd riadó terv. Ezek közül a fenntartható fejlődési stratégiát, illetve az energiastratégiát fogom vizsgálni, így a környezetvédelmi programokkal együtt összesen háromféle stratégiát. A vizsgálat alapja, hogy van-e ezen stratégiák megalkotására irányuló nemzeti szintü jogi elöírás a háttérben, $s$ ha igen, az miként érvényesül helyi szinten, továbbá azt is bemutatom, hogy a központi szabályozás megfel-e a stratégiákra nézve, a szakirodalomban megfogalmazott általános elyárásoknak. Ha pedig nincs nemzeti szintủ elöírás, úgy a megalkotott stratégiák megfelelnek-e a rájuk irányadó szakirodalmi követelményeknek. Végezetül, kérdés az is, hogy - a tapasztaltakra figyelemmel - miként értékelhető a központi és a helyi szabályozás erőegyensúlya e stratégiák tekintetében? 


\section{Környezetvédelmi stratégiák és szakirodalmi követelmények}

A különböző környezetvédelmi tervek megalkotására és tartalmára nézve viszonylag széles szakirodalom létezik. ${ }^{2}$ Ezek több tekintetben is egységes állásponton vannak. Így egyöntetü elvárásként fogalmazzák meg a stratégiák vertikális és horizontális integrációját. Ez egy helyi szintü stratégia esetében azt jelenti, hogy egyaránt figyelemmel van a magasabb szinten már megalkotott (megyei, regionális, nemzeti) stratégiákra (vertikális integráció) valamint más helyi szintü ágazati stratégiákra (horizontális integráció). Fontos, hogy ez a koherencia ne csupán formálisan, hanem tartalmában is érvényesüljön. E követelmény érvényesüléséhez nem elegendő tehát az egyszerủ utalás a magasabb szintü stratégia létére. Azonban, véleményem szerint, ez a követelmény még nem sérti annak lehetőségét, hogy a települési önkormányzatok a magasabb szintü környezetvédelmi tervekhez képest (nemzeti, európai uniós) akár komolyabb célokat (szigorúbb követelmény) határozzanak meg. Erre a Kvtv. az önkormányzatokat a jogalkotás kapcsán kifejezetten felhatalmazza. Ennek analógiájára a települési önkormányzatok e jogának, úgy gondolom, hogy a stratégiaalkotás tekintetében is élnie kell. Legalábbis a környezetvédelmi programok, fenntartható fejlődési stratégiák, klímavédelmi stratégiák tekintetében biztos, viszont az energiastratégiák kapcsán ez már érdekes kérdés, hiszen ezek nem kifejezetten környezetvédelmi témájúak. Ugyanakkor a környezetre gyakorolt hatásuk miatt kétségtelenül a legmeghatározóbb szakpolitikák közé tartoznak. Ha tehát egy települési önkormányzatnak ambiciózus elképzelései vannak az energiafelhasználásának volumene és szerkezete (zöld energia előnyben részesítése) tekintetében, miért ne tehetné meg, hogy a nemzeti energiastratégiához képest komolyabb célokat fogalmazzon

${ }^{2}$ Dalal-Clayton, Barry-BAss, Stephen: Sustainable Development Strategies: A Resource Book OECD and UNDP. OECD, New York, 2002; SwANSON, DarrenPINTER, László-Bregha, Francois-VolKery, Axel-JACOB, Klaus: National Sustainable Development Strategies. Environment Policy Research Centre of the Free University of Berlin, and Deutsche Gesellshaft für Technische Zusammenarbeit, Stratos, 2004. 
meg? $?^{3} \quad$ Erre szolgálhat példaként Kaposvár, amelynek energiastratégiája 2050-re azt a célt tüzte ki, hogy 100\%-ban megújuló energiaforrásra alapozza energiaellátását. ${ }^{4}$ Ennek lehetőségével (ti. 100\%-os megújuló energia részarány) a nemzeti megújuló energia stratégia még elméletileg sem foglalkozik. ${ }^{5}$

$\mathrm{Az}$ is nagyon fontos elvárás, hogy a környezetvédelmi stratégiaalkotás folyamatában széleskörü és hatékony társadalmi részvételt biztosítsanak. Természetesen ez sem egy formális, eljárásjogi kötelezettség kell, hogy legyen, hanem a társadalom valódi bevonása és véleményének figyelembe vétele egy olyan stratégia megalkotásába, amely hatással van a lakókörnyezetére. Ehhez az is követelmény, hogy a stratégiák tervezeteiről a helyi lakosok, illetve civil szervezetek időben értesüljenek, legyen kellő idejük a terv átgondolására annak érdekében, hogy érdemben közremüködhessenek.

Harmadrészt kiemelten fontos a terv folyamatos figyelemmel kísérése és a megvalósítás értékelése is. Szemben egy csak a „kirakatba való” környezetvédelmi stratégiával, amelyet tulajdonképpen még a helyi önkormányzat sem vesz komolyan. ${ }^{6}$

Végezetül van még egy szintén nem elhanyagolható követelmény, méghozzá a környezetvédelmi terv figyelembe vétele a helyi döntési folyamatokban. E követelmény érvényesülése nélkül a stratégia halott, hiszen pontosan az élteti, ha alkalmazzák. Ha nem veszik figyelembe nincs semmi értelme az egész folyamatnak, az nem tölti be a funkcióját.

\footnotetext{
3 Ezt a jogot erősíti a RED (a megújuló energiaforrásból előállított energia támogatásáról szóló 2009/28/EK irányelv) preambuluma, amely kifejezetten rögzíti, hogy a „...tagállamok ösztönözhetik a helyi és regionális hatóságokat a nemzeti célkitüzéseket meghaladó célok meghatározására ... ” Preambulum 23.

4 http://www.somogyma.hu/2015/06/30/smart-city-kaposvar/ (2016. 01. 18.); Bár kevésbé ambiciózus, de mégiscsak komoly célokat fogalmaz meg például Zalaegerszeg is 2014-ben elfogadott Megújuló Energia Stratégiájában. http://zalaegerszeg.hu/dokumentum/22984/Zeg_ITS_MegujuloEnergiaStrategia_kuld ott0725.pdf (2016.01.18.).

${ }^{5}$ Stratégia a magyarországi megújuló energiaforrások felhasználásának növelésére 2008-2020. Budapest, 2008.

${ }^{6}$ Meadowcroft, James: National sustainable development strategies: features, challenges, and reflexivity. European Environment 2007/3, 28.
} 
Miután áttekintettem a legfontosabb szakirodalmi követelményeket, egyenként sorra veszem és megvizsgálom a fentebb már jelzett stratégiákat.

\section{Települési környezetvédelmi programok}

A Környezet védelmének általános szabályairól szóló 1995. évi LIII. törvény (Kvt.) a települési önkormányzatokat arra kötelezi, hogy önálló települési környezetvédelmi programot ${ }^{7}$ dolgozzanak ki (48/E.§). E rendelkezés célja nyilván az, hogy a környezetvédelem települési szinten se egy ad hoc jellegü, „tüzoltó” tevékenység legyen, hanem egy jól átgondolt terv arra vonatkozóan, hogy a település miként akarja csökkenteni a káros környezeti hatásokat, és javítani a környezet állapotán. Ez azért is fontos, mert a településeken a környezeti ártalmak (pl. levegőterhelés, zajkibocsátás, hulladékkeletkezés, szennyvízkibocsátás stb.) koncentrált formában jelennek meg, és már önmagában azzal, hogy a települések területet foglalnak el a természeti környezettől, nyilván negatív hatással vannak arra.

Bár most a települési környezetvédelmi programokkal foglalkozom, látnunk kell, hogy a Kvt. a környezetvédelmi tervezés átfogó rendszerét rendeli létrehozni, amelyben a települési környezetvédelmi programok csak egy szeletet képeznek. Azon kívül, részben vele hierarchikus viszonyban (felette), részben pedig az általános és speciális viszonyában számos (országos, regionális, megyei, kistérségi, illetve hulladékgazdálkodási, természetvdédelmi, egyedi, stb.) tery létezik még. Az 1. sz. ábra ezt a rendszert szemlélteti.

7 Egy kapcsolódó megjegyzés: érdekes kérdés a települési környezetvédelmi programokat érintö hatásvizsgálat (környezeti vizsgálat) szükségessége. Véleményem szerint az egyes tervek és programok környezeti vizsgálatáról szóló 2/2005. (I.11) kormányrendeletböl nem lehet egyértelmúen arra a következtetésre jutni, hogy a települési szinten készített átfogó környezetvédelmi programok környezeti vizsgálat hatálya alá tartoznának. Az egyes ágazati (pl. energiafelhasználással, közlekedéssel) kapcsolatos tematikus tervek esetén már jobban kiolvasható a kötelezettség, de az is minden esetben egyedi mérlegelést igényel. 
1. Ábra - a környezetvédelmi programok föbb típusai

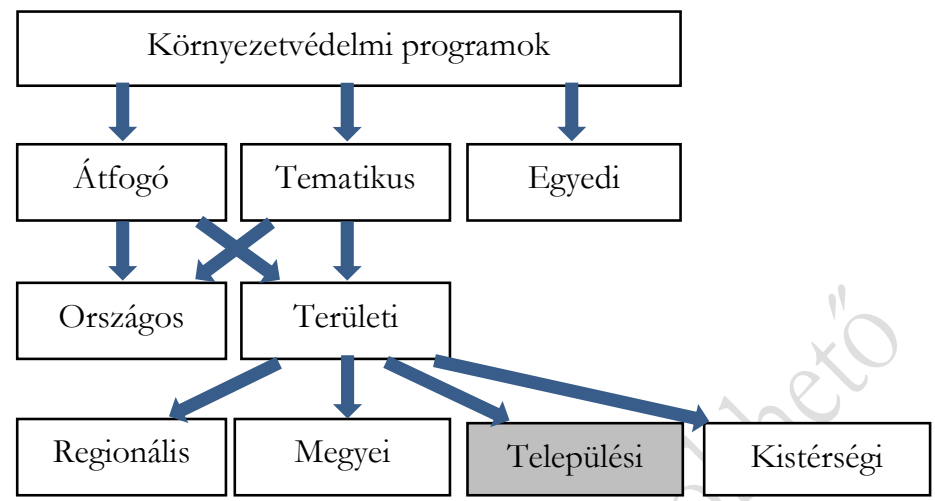

A Kvt. azzal, hogy elöírja, hogy a tervezés során az alacsonyabb területi szintü környezetvédelmi tervet a magasabb területi szintü környezetvédelmi tervekkel, a tematikus és az egyedi környezetvédelmi terveket az adott területi szint átfogó környezetvédelmi tervével össze kell hangolni [48/A.§ (2)], biztosítja a különböző tervek vertikális és horizontális integrációját. Ennek előírása, és nem utolsó sorban megfelelő végrehajtása, garanciális jelentőségű az ilyen programok megalkotásánál. A környezetvédelmi terv készítőjének az előkészítés során gondoskodnia kell a terv széleskörü társadalmi egyeztetéséről is [48/A.§ (3) ]. Hogy ez milyen eljárási rend szerint történjen (pl. a tervezés milyen szakaszában, milyen határidőkkel), illetve a vélemények figyelembe vételére vonatkozó kötelezettséget már nem tartalmazza. A kutatási projektünk keretében folytatott interjúkból ${ }^{8}$ az derül ki, hogy a helyi lakosok (és különösen a zöld szervezetek) alig kapnak lehetőséget véleményük becsatornázására, pedig egy ilyen fontos helyi program tekintetében ez különös jelentőséggel bírna. A törvény nemcsak a lakosság, hanem a szakmai szempontok érvényre juttatását is szolgálja. Teszi ezt azzal, hogy a program tervezetét meg kell küldeni véleményezésre az illetékes

${ }^{8}$ A kutatás hipotéziseit és módszerit egy tanulmányban foglaltuk össze: FODOR László-BARTA Attila-FÓNAI Mihály-BÁNYAI Orsolya: Települési környezetvédelem Magyarországon: Egy kutatás előfeltevései. Tér és Társadalom 2016/3, 19-39. 
környezetvédelmi hatóságnak. A hatóságnak harminc napja van a vélemény megadására. Szintén törvényi kötelezettség, hogy a területi környezetvédelmi programot szükség szerint, de legalább a program megújítását, illetve felülvizsgálatát követően felül kell vizsgálni. [48./B.§ (4)] A Kvt. eredetileg kétévente írt elő felülvizsgálati kötelezettséget, de ezt egy 2009-ben hatályba lépő módosítás kivette. Ezzel kapcsolatban nem lehet elégszer hangsúlyozni, hogy a felülvizsgálati kötelezettség nem lehet csupán formális jellegü. Nemcsak olcsóbb, de a hatékony környezetvédelmi tervezés egyik legfontosabb követelménye a szakirodalom szerint. ${ }^{9}$ A Kvt. szerint továbbá a területi környezetvédelmi programokban foglaltakat az adott területi szint fejlesztési koncepciójának és rendezési, valamint fejlesztéspolitikai terveinek kidolgozása, a döntéshozatal és a végrehajtás, továbbá az adott területre vonatkozó ágazati tervezés során érvényre kell juttatni. [48./B. § (3)] E törvényi kötelezettség lényegében e tervek figyelembe vételére irányuló kötelezettség jogi alapjait teremti meg. A Kvt. e kötelezettségeken felül meghatározza még az átfogó terv tartalmára vonatkozó alapvető elöírásokat is. Ezek két részre oszthatók. Egyik részük [Kvt. 48/B. §. (2)] valamennyi környezetvédelmi tárgyú átfogó terv minimumára (pl. helyzetértékelés; célállapotok, eszközök, stb.), a másik részük [48/E. $\S$ (1)] kifejezetten a települési önkormányzatok által készítendő tervekre vonatkozik. E tartalmi elemek egyik köre kötelező elem, (pl. a légszennyezettség-csökkentési intézkedési programmal; zöldfelület-gazdálkodással; a kommunális szennyvízkezeléssel; az energiagazdálkodással kapcsolatos feladatok és elöírások), a másik köre szabadon választható (ilyen például a természet és a táj védelmével kapcsolatos feladatok meghatározása).

A törvény a tervezés elmulasztása esetére negatív jogkövetkezmények alkalmazását nem irányozza elő. Ez a jog szigorát puhítja, és hozzájárul a jogkövetés lazaságához (lásd. ezzel kapcsolatban e fejezet utolsó bekezdését). Többek között ez is az oka annak, hogy bár a törvényt 1995-ben fogadták el, a legtöbb települési önkormányzat a mai napig nem készített környezetvédelmi

9 TANG, Zhenghong-BRODY, Samuel: Linking planning theories with factors influencing local environmental-plan quality. Environment and Planning B: Planning and Design 2009/36. $522-537$, 534. http://digitalcommons.unl.edu/cgi/viewcontent.cgi?article=1004\&context=arch_crp_f acultyschol (2016.01.18.). 
programot. Olyan hivatalos adatról, hogy pontosan ez mennyi települést jelent, eredetileg nem volt tudomásom. Ezért - bár nem tudományos igénnyel, csupán egy hozzávetőleges arány meghatározására - végeztem egy egyszerü felmérést, amelynek keretében (egy általánosan használt keresőmotor segítségével) összeszámoltam az interneten elérhető települési környezetvédelmi programokat. E kis kutatásból az derült ki, hogy bár Magyarországon 3155 település van, mindössze 111 települést találtam, amelynek van (elérhetö) környezetvédelmi programja. Az adat nyilvánvalóan nem pontos, mindenesetre a nagyságrend szemléltetésére alkalmas. Idöközben a környezetvédelmi programmal rendelkezö települések számát egy 262 önkormányzatra kiterjedő kérdőíves kutatás keretében is vizsgáltuk, immár tudományos igénnyel. E kérdőíves felmérés eredménye szerint a válaszadó önkormányzatok 95\%-a rendelkezik környezetvédelmi programmal (megjegyzés: a kérdőívet kitöltők 13 százaléka nem írt semmilyen választ erre a kérdésre). Ez látszólag azt jelzi, hogy sokkal több települési önkormányzatnak van környezetvédelmi programja, mint ahányan az interneten is hozzáférhetővé tették. A magas számarányt éppen a saját korábbi kutatásom alapján azonban a magam részéről úgy értelmezem, hogy a válaszadók jelentős része valószínüleg minden, környezetvédelmi vonatkozású, helyi programot illetve programrészt figyelembe vett, $\mathrm{s}$ nem csak a Kvt. szerinti települési környezetvédelmi programot. Ezt az a kutatási tapasztalat is erösíti, hogy az önkormányzatok a legtöbb esetben nincsenek tisztában a pontos szakmai terminológiával, illetve azt nem megfelelően használják. A kutatás eredményeképpen még az is kiderült, hogy fenntartható fejlődési stratégiája (Local Agenda 21 programja) csak a kérdőívet kitöltő önkormányzatok 32 százalékának van. Energia stratégiát a válaszadó önkormányzatok tizedénél, éghajlat változási stratégiát pedig mindössze 4 százalékuknál készítettek.

Az e tanulmány alapját képező, „, A helyi önkormányzatok szerepe és lehetöségei a környezetvédelmi jog és politika alakitásában" c. konferencia kerekasztal-beszélgetésén az hangzott el, hogy az önkormányzatok a tapasztalatok alapján a gyakorlatban alapvetően három okból készítenek környezetvédelmi programot. Az első az, hogy komolyan veszik a törvényi kötelezést, a második, hogy a megalkotására anyagi támogatást kapnak valamilyen forrásból, a 
harmadik, hogy közösségi igény merül fel a megalkotására valamilyen helyi környezeti probléma miatt.

Függetlenül attól, hogy pontosan mi is motiválta azt a néhány önkormányzatot a települési környezetvédelmi program megalkotására, egy dolog biztos. Az, hogy az a jelenség, miszerint a települési önkormányzatok egyszerüen nem hajtják végre a központi elöírást, nem vezethetö vissza arra, hogy a törvény idevágó rendelkezései ne felelnének meg a környezetvédelmi tervekkel kapcsolatos szakirodalmi követelményeknek, hiszen minden fentebb, külön fejezetben említett követelmény megjelenik a központi szabályozásban (ami még akkor is igaz, ha a szabályozás fejleszthetö, pl. amiatt, hogy nagyon általános a társadalmi részvétellel kapcsolatos követelmény). Ezzel szemben a törvényi elöírás a jogszabályi rendelkezések hatékony érvényesüléséhez szükséges alapfeltételekkel, mint pl. teljesítési határidö, jogkövetkezmény, már nem rendelkezik. Ez már nyilvánvalóan oka lehet a törvényi kötelezettség egyszerü figyelmen kívül hagyásának. A mulasztás másik okát Szabó abban látja, hogy mind a program elkészítése, mind a végrehajtása komoly anyagi költségeket jelent, és az önkormányzatoknak sok esetben megterhelö annak elkészítése/elkészíttetése. ${ }^{10}$ Az előbbiek alapján úgy gondolom, hogy már érthetö, mi állhat a fenti jelenség hátterében.

Ezek után térjünk át a fenntartató fejlődési stratégiákra, amelyek a környezetvédelmi programokkal ellentétben a környezeti szempontokon kívül gazdasági és társadalmi érdekeket is érvényesítenek, így elméletileg kiváló lehetőséget biztosítanak a települések számára a helyi környezeti fenntarthatóság alapjainak megteremtésére.

\section{A fenntartható fejlődési stratégiák}

A közép-, vagy hosszú távú stratégiaalkotás kulcsfontosságú a fenntartható fejlődés érvényesítésében, hiszen ad hoc jellegü, és pillanatnyi érdekek által befolyásolt döntésekkel semmilyen célt nem lehet elérni, nemhogy a fenntartható fejlödést érvényesíteni. Többek között a fenntartható fejlődési stratégiák elkészítése és megvalósítása

\footnotetext{
${ }^{10}$ SZABÓ György: A települési önkormányzatok környezetvédelmi feladatai. Debreceni Egyetem, Debrecen, 2008, 38.
} 
szükséges tehát ahhoz, hogy az elv valósággá váljon. ${ }^{11}$ Éppen emiatt az ENSZ 1992-es Környezet és Fejlődés Világkonferenciáján elfogadott Agenda 21 (Feladatok a XXI. századra) címü akcióprogramja is elvárja nemzeti fenntartható fejlödési stratégiák elfogadását. ${ }^{12}$ Természetesen itt nem egyszerü tervekről van szó. A stratégiaalkotásnak egy összetett és dinamikus folyamatnak kell lennie, és számos követelménynek kell megfelelnie. Ezekről mind az OECD, mind az ENSZ több iránymutatást adott ki, amelyek egyébként alapvető hasonlóságot mutatnak. ${ }^{13}$ Bár a fenntartható fejlődési stratégiákat elsősorban nemzeti szinten kell elfogadni, ugyanolyan fontos, - tekintve az önkormányzatok jelentőségét a fenntartható fejlődés érvényesítésében - sőt, néhány szakirodalmi álláspont szerint még hatékonyabb a helyi szintü stratégiaalkotás. ${ }^{14}$ $\mathrm{Az}$ önkormányzatoknak ezt a feladatát az Agenda 21 címü akcióprogram is kifejezetten megemlíti. Ez a dokumentum ugyan jogi kötőerővel nem rendelkezik, de ettől még meghatározó jelentőségü. Lényegében nemzetközi szervezetek, kormányok és a civil társadalom számára szóló javaslatok és ajánlások gyüjteménye. Az akcióprogram 28. fejezete megerősíti a helyi önkormányzatok jelentőségét a fenntartható fejlődés érvényesítésében, és célként fogalmazza meg, hogy a helyi önkormányzatok (local authorities) a lakosság bevonásával helyi fenntartható fejlödési stratégiákat (local Agenda 21) fogadjanak el 1996-ra. A határidő majdhogynem csak jelképes, hiszen örülhetünk, ha egyáltalán valamikor elfogadtak ehhez hasonló programokat a települési önkormányzatok. A fenntartható fejlödési stratégiák megalkotása ugyanakkor a helyi önkormányzatok érdeke is, amit mi sem mutat jobban, minthogy bár a fenti követelmény csak egy ajánlás, és elmulasztásához nincsenek jogkövetkezmények csatolva, vannak olyan helyi önkormányzatok Magyarországon, amelyek törekednek hasonló tervek elfogadására. ${ }^{15}$

${ }^{11}$ BÁNYAI Orsolya: Energiajog az ökológiai fenntarthatóság szolgálatában. DELA, Debrecen, 2014, 45.

${ }^{12}$ Agenda 21. 8. fejezet 8.7.

${ }^{13}$ Good Practices in the National Development Sustainable Development Strategies of OECD Countries, OECD, 2006, 12.

${ }^{14}$ IANNARONE, Sarah Stacy: Cultivating wisdom and creativity in practice and theory. Wisdom and Creativity, 2008. http://web.pdx.edu/ sari/Wisdom_Creativity_Draft.pdf (2017.01.07.).

15 Ezek közül sokat meg lehet találni a világhálón. Például Szeged, Miskolc, Hajdúszoboszló, Szekszárd, Ada, Mórahalom, stb. fenntartható fejlődési stratégiáját. 
Arról, hogy pontosan hány ilyen önkormányzat van, nincs pontos adatom, azonban e körben is végeztem egy nem tudományos igényü rövid kutatást az interneten, és kiderült, hogy a világhálón 64 település fenntartható fejlödési stratégiája érhető el. Ahhoz képest, hogy a fenntartható fejlődési stratégiák megalkotására még jogi elöírás sincs, nem is rossz az arány.

A helyi stratégiaalkotással szemben egyébként ugyanazokat az elméleti követelményeket lehet megfogalmazni, mint általában a környezetvédelmi programokkal szemben. Vagyis érvényesüljön bennük a holisztikus (integratív) szemlélet, építsenek az önkormányzat már meglévő ágazati célkitüzéseire, terveire, és fogják össze azokat (horizontális integráció), ${ }^{16}$ széles körü nyilvánosság bevonásával fogadják el őket, és legyen rendszeres a visszacsatolásuk. Továbbá itt is ki kell emelni a vertikális integrációval kapcsolatos elvárást, ti. a helyi fenntartható fejlődési stratégiák integrálják az országos fenntarthatósági stratégiák céljait, prioritásait. Ez természetesen tartalmi követelmény, több annál, mint amikor a helyi stratégia egyszerüen utal az országos vagy az európai uniós fenntartható fejlődési stratégiára. A horizontális integrációval kapcsolatos, fenti követelményt a magyar Nemzeti Fenntartható Fejlödési Keretstratégia (NFFK) is kifejezetten tartalmazza: „a [fenntarthatósági] célkitüzéseket minden kormányzati, regionális vagy helyi döntés - legyen az hosszabb távú ágazati stratégiák megalkotása, jogszabály-alkotás, a költségvetés tervezése vagy egy településrendezési terv - során érvényre kell juttatni. "l7 Ezenfelül az NFFK maga is több pontjában foglalkozik a "helyi kormányzás” feladataival és lehetőségeivel. Például lefekteti a központi és helyi kormányzat közötti munkamegosztás elvi alapját is: „A lokális ökológiai problémákra, kihivásokra a helyi közösségek és alsóbb szintü kormányzatok adnak választ, míg a központi kormányzat kezeli a nemzeti jelentőségü problémákat.

Végezetül egy eddig még nem említett tartalmi követelmény: a fenntartható fejlődési stratégia ideális esetben érvényesíti az ökológiai (más néven erős, a környezeti érdekek elsődlegességén

\footnotetext{
${ }^{16}$ A témánk kapcsán itt a klíma-és energiastratégiákat (néhol megújuló energia stratégiákat), környezetvédelmi programokat kell ezzel összefüggésben kiemelni.

17 18/2013. (III.28.) OGY határozat a Nemzeti Fenntartható Fejlődési Keretstratégiáról. 3.5. (4) 33.

${ }^{18}$ NFFK 3.4, 32.
} 
alapuló) fenntarthatóság követelményét. ${ }^{19}$ Nem meglepő ugyanakkor, hogy ilyen esettel alig találkozni, legfeljebb egy-két települési fenntartható fejlődési stratégia említi a fenntartható fejlödésnek ezt az értelmezését (de azok sem alkalmazzák következetesen). ${ }^{20}$ A szakirodalom ezt többek között azzal indokolja, hogy a helyi stratégiák úgy fogadták be a nemzetközi dokumentumok szellemiségét, hogy meg sem kérdőjelezték azok helyességét. Vagy egyszerüen arról van szó, hogy a települések vezetöi jól tudják, hogy a lakosság ellenállásába ütköznének, ha minden területen a környezetvédelmi érdekeket helyeznék előtérbe. ${ }^{21}$

Egy 2012-ben folytatott kutatásból kiderül, hogy a jelenleg elérhető (a világhálón hozzáférhető) fenntartható fejlődési stratégiák sok esetben nem felelnek meg a szakirodalomban támasztott követelményeknek. ${ }^{22}$ Nemcsak az általános, környezetvédelmi tervekkel kapcsolatos, hanem az ökológiai fenntarthatósággal kapcsolatos követelményeknek sem. A meglévő fenntartható fejlődési stratégiák ugyanis elsősorban a gyenge fenntarthatóság elvét tartják szem előtt. Ugyanakkor magam is egyetértek azzal, hogy ez nem feltétlenül jelent problémát, hiszen a helyi önkormányzatok tökéletesen érzékelhetik, hogy egy olyan stratégia, amely minden ponton a környezeti érdekeket helyezi elötérbe, a helyi lakosságnak nehezen lehet elfogadható, még akkor is, ha az elv elméleti helyessége vitathatatlan. ${ }^{23} \mathrm{Nem}$ beszélve arról, hogy általában a szakirodalomban is a gyenge fenntarthatóság használatát helyezik elötérbe. ${ }^{24}$ Söt, korábbi kutatásaim eredményeként elmondhatom, hogy a nemzetközi, európai és magyar jogi dokumentumok is a fenntarthatóság gyenge értelmezését támogatják. ${ }^{25}$ Véleményem szerint azonban mindez nem zárja ki annak a lehetőségét, hogy az ökológiai fenntarthatóság elvét a helyi

\footnotetext{
${ }^{19}$ BÁNYAI: i.m., 33.

${ }^{20}$ BAJÁK Imre: A fenntartható fejlődés helyi stratégiáinak esélyei Magyarországon. Doktori értekezés, Debrecen, 2012. 45, 170.

${ }^{21}$ BAJÁK, Imre-TÖRCSVÁRI, Zsolt: Local sustainable development programs in Hungary. Periodica Oeconomica 2012, 81-87.

${ }^{22}$ BAJÁK (2012): i.m., 45, 176.

${ }^{23}$ BAJÁK (2012): i.m., 45, 176.

${ }^{24}$ KEREKES Sándor: A fenntartható fejlödés európai szemmel. In: Gömbös Ervin (szerk.) Globális kihívások, milleniumi fejlesztési célok és Magyarország. Magyar ENSZ Társaság, Budapest, 2008, 51-60, 56.

${ }^{25}$ BÁNYAI: i.m., 250.
} 
stratégiák értékként megemlítsék. Azzal ugyanis, hogy még csak meg sem említik, tagadják annak helyességét, és már a kezdet kezdetén bezárják a kaput az esetlegesen ebbe az irányba tartó későbbi fejlődés elött. Az ökológiai fenntarthatóság gondolata attól még érték marad, hogy társadalmunk hozzáállása miatt - jelenleg esetleg nincs reális lehetőség a megvalósítására.

\section{Települési önkormányzatok energiafelhasználással kapcsolatos stratégiaalkotása}

Az eddigiek során láthattuk, hogy a települési önkormányzatok számára a stratégiaalkotás kötelezettsége ius cogens jelleggel egyedül a környezetvédelmi programok tekintetében áll fenn (legalábbis ami a témánkat érintő terveket illeti). Ez a megállapítás az energiastratégiákra vonatkozó joganyag vizsgálata után is érvényes, ugyanis jelenleg az európai uniós és magyar jogban nincs olyan elöírás, amely arra kötelezné a települési önkormányzatokat, hogy energiastratégiákat fogadjanak el. Ugyanakkor meg kell említeni, hogy az energiahatékonysági irányelv (EED) ${ }^{26}$ alapján a tagállamoknak elméletileg ösztönözniük kell a közintézményeket, ${ }^{27}$ hogy fogadjanak el egy különálló, vagy pedig egy szélesebb körü éghajlatváltozási, környezetvédelmi terv részét képező energiahatékonysági tervet, amely konkrét energiamegtakarítási és hatékonysági célkitüzéseket és intézkedéseket tartalmaz. ${ }^{28} \mathrm{Az}$ természetesen vitára adhat okot, hogy az „ösztönzés” kifejezés itt pontosan mit is jelent, továbbá az is, hogy ez a kötelezettség csak az energiafelhasználás volumenére vonatkozik, míg a szerkezetére nem. Ettől függetlenül az energiahatékonyságról szóló 2015.évi LVII. törvény (energiahatékonysági törvény) az EED fentebbi

\footnotetext{
${ }^{26}$ Az energiahatékonyságról szóló 2012/27/EU irányelv.

${ }^{27}$ „Közintézmény”: az épitési beruházásra, az árubeszerzésre és a szolgáltatásnyújtásra irányuló közbeszerzési szerzödések odaitélési eljárásainak összehangolásáról szóló, 2004. március 31-i 2004/18/EK európai parlamenti és tanácsi irányelvben (2) meghatározott bármely ajánlatkérö szerv. Ezen irányelv 1. cikk (9) bekezdése szerint „,Ajánlatkérö szerv”: az állam, a területi vagy a települési önkormányzat, a közjogi intézmény, továbbá az egy vagy több ilyen szerv, illetve közjogi intézmény által létrehozott társulás. Vagyis a települési önkormányzat beletartozik a közintézmény fogalmába.

${ }^{28}$ EED 5. cikk (7) bekezdés.
} 
rendelkezéseit nem implementálta. Így ilyen önkormányzati feladatról gyakorlatilag sem a törvény, sem a végrehajtását szolgáló rendelet ${ }^{29}$ nem tesz említést.

Ami a megújuló energiákkal kapcsolatos cselekvési terveket illeti, a megújuló energiaforrásból előállított energia támogatásáról szóló irányelv (RED) ${ }^{30}$ bár kifejezetten rögzíti annak lehetőségét, hogy a tagállamok ösztönözzék a helyi és regionális hatóságokat a nemzeti célkitüzéseket meghaladó célok meghatározására ${ }^{31}$ - nem tartalmaz arra vonatkozó kötelezettséget, hogy a helyi vagy regionális önkormányzatok a nemzeti megújuló energia cselekvési tervekhez hasonló stratégiákat fogadjanak el. Bár az is igaz, hogy mivel az irányelv a tagállamokat kötelezi a megújuló energetikai célok teljesítésére, és nem a helyi önkormányzatokat, ${ }^{32}$ ennélfogva a stratégiaalkotásra irányuló kötelezés nem is lett volna helyénvaló.

Vagyis az Európai Unió joga a maga „puha” eszközeivel ösztönzi ugyan a megújuló energiaforrások részarányával, illetve az energiafelhasználás csökkentésével kapcsolatos helyi/regionális elképzelések stratégiai szintü megfogalmazását, azonban erre vonatkozó konkrét és egyértelmüen számon kérhető kötelezettséget nem tartalmaz. A magyar országos hatályú jogszabályok pedig még említés szintjén sem tartalmaznak erre vonatkozó rendelkezéseket. Így ha léteznek is ilyen helyi programok, azok csak a települési önkormányzatok egyéni ambícióinak köszönhetők. Rövid internetes felmérésem eredményeként 9 települést találtam, amelyik rendelkezik energiastratégiával. Meg kell azonban jegyeznem, hogy sok esetben annak ellenére, hogy nincs egy településnek energiastratégiája, a helyi fenntartható fejlődési stratégiákban szerepelnek energetikai célkitüzések, illetve az éghajlat-változási stratégiák néhány esetben gyakorlatilag energiastratégiáknak

${ }^{29}$ 122/2015. (V. 26.) Korm. rendelet az energiahatékonyságról szóló törvény végrehajtásáról.

30 2009/28/EK irányelv (2009. április 23.) a megújuló energiaforrásból elóállított energia támogatásáról, valamint a 2001/77/EK és a 2003/30/EK irányelv módosításáról és azt követő hatályon kívül helyezéséről.

${ }^{31}$ RED Preambulum 23. pont: „A tagállamok ösztönözhetik a helyi és regionális hatóságokat a nemzeti célkitüzéseket meghaladó célok meghatározására, valamint bevonhatják a helyi és regionális hatóságokat a nemzeti cselekvési tervek kidolgozásába és a megújuló energiaforrásokból elöállitott energia elönyeinek tudatositásába."

${ }^{32}$ BÁNYAI: i.m., 163. 
számítanak. Úgyhogy az előbbi szám önmagában nagyon keveset mond.

Kifejezetten energia-, vagy megújuló energia stratégiák tartalmára nézve nem találtam a szakirodalomban megfogalmazott követelményeket, de néhány alapvető elvárás e nélkül is körvonalazható: mutassák be a helyi földrajzi adottságokat, az energiaellátás általános helyi szerkezetét, fogalmazzák meg közép vagy hosszú távú elképzeléseiket, és az azok megvalósítását szolgáló, helyi hatáskörbe tartozó intézkedéseiket, az energiafelhasználás csökkentésével, illetve megújuló energiaforrások részarányának növelésével kapcsolatban. Továbbá a környezetvédelmi tervekkel kapcsolatban már megfogalmazott általános követelményekkel összhangban, fontos koherenciát is kialakítani más ágazati (pl. környezetvédelmi, éghajlat-változási vagy fenntartható fejlödési), illetve országos szintü tervekkel (pl. Nemzeti Energiastratégia 2030). Ez utóbbi természetesen tartalmi követelmény, több annál, mint amikor a helyi stratégia egyszerüen utal más ágazati, vagy magasabb szintü stratégiára.

Az ökológiai fenntarthatóság érvényesítése érdekében az előbbi elvárásokat egészítsük ki még legalább két követelménnyel. ${ }^{33}$ Ahhoz, hogy elmondhassuk, hogy egy energetikai stratégia érvényesíti az ökológiai fenntarthatóság elvét, alapvető, hogy megfogalmazza az energiafelhasználás abszolút csökkentésének, és a helyi földrajzi adottságokhoz igazodva, a kevesebb káros környezeti hatással járó energiahordozókra épülö, „zöldebb” energiaellátási struktúra kialakításának követelményét. ${ }^{34}$ Bevallom, ez nagyon szigorú elvárás, és feltételezem, hogy a települési önkormányzatok energetikai stratégiái sem felelnek meg ennek a követelménynek. Ez természetesen nem a helyi szint sajátossága, hiszen az ökológiai fenntarthatóság elvét, illetve ennek érvényesülését szolgáló szabályozási elemeket a magasabb szabályozási szintek sem érvényesítik (vagy csak parciálisan). ${ }^{35}$ Hozzáteszem, ennek a követelménynek a helyi szintü megvalósítása nehezebb, mivel az energiaellátás jellemzően országos hálózatokon keresztül történik, amire az önkormányzatoknak nincs ráhatása. Egyedül a

\footnotetext{
${ }^{33}$ PARAYIL, Govindan: Sustainable Development: The Fallacy of a NormativelyNeutral Development Paradigm. Journal of Applied Philosophy, 1998/ 2,179-194.

${ }^{34}$ BÁNYAI: i.m., 250-251.

${ }^{35}$ BÁNYAI: i.m., 250-251.
} 
távhőszolgáltatás a kivétel, mert annak országos hálózata nem alakult ki, jellemzően helyi szinteken történik. Ezért is különösen fontos, hogy a helyi önkormányzatok energetikai stratégiájukban meghatározzák a távfütés helyét, szerepét és jövőjét a település életében. ${ }^{36}$

\section{5. Összegzés és következtetés}

A fent említett stratégiák gyakorlatilag közvetlenül befolyásolják a helyi környezetvédelmet. Láthattuk, hogy a három stratégia típus közül csupán a környezetvédelmi programoknak van tényleges jogszabályi háttere. A fenntartható fejlődési és energiastratégiák tekintetében nincs, holott a szakirodalom már megfogalmazott olyan álláspontot, amely a helyi fenntarthatóság térnyerése előtt álló számos akadály közül a törvényi háttér hiányát emelte ki. ${ }^{37}$ Ennek megteremtéséhez akár a környezetvédelmi programokat elöíró törvényi rendelkezésekből is ki lehet indulni, természetesen kiküszöbölve az érvényesülését nyilvánvalóan gátló tényezőket (pl. a jogkövetkezmények, a határidő hiánya). A jogszabályi háttér fejlesztése azonban még mindig kevés. Ezzel együtt szükség lenne annak a tudatosítására és megfelelő, hatékony kommunikálása, hogy a fenntartható fejlödés, az energiafelhasználás csökkentése és a zöld energia részarány növelése yalóban minden település és az ország érdeke. Vagyis a témát komolyságához mérten kellene kezelni. Ezenfelül meg kellene szüntetni a másik legnagyobb akadályt: a forráshiányt. A szakirodalomból az derül ki, hogy a települések a legtöbb esetben egyszerüen pénzügyi források hiánya ${ }^{38}$ miatt nem fordítnak figyelmet a helyi környezeti ügyek és a fenntarthatóság tudatos hosszú távú kezelésére és tervezésére. A külföldi - svéd, finn, olasz, angol - példák is azt mutatják, hogy az elhatározáson kívül a központi kormányzat anyagi támogatása is szükséges a

\footnotetext{
${ }^{36}$ Távhő Szakmai Bizottság, é.n.: A távhöpiac versenyképes müködési modellje. 3. sz. munkaanyag.

https://www.levego.hu/sites/default/files/koltsegvetes/m12.htm (2016. 01.14.).

37 BAJÁK Imre: Gátló tényezők a helyi fenntarthatóság térnyerése előtt Magyarországon. Agrártudományi közlemények, 2007/26. 151-157.

${ }^{38}$ BAJÁK Imre: A helyi fenntartható fejlödési stratégiák helyzete Magyarországon. Acta Carolus Robertus 2013/2, 9-21.
} 
megfelelő eredményhez. ${ }^{39}$ Ilyen körülmények között, és a települések pozitív hozzáállása mellett, elméletileg nálunk is el lehetne érni az olyan bíztató példákat, mint az Egyesült Királyságban, ahol gyakorlatilag a települések 93\%-a rendelkezik fenntartható fejlődési stratégiával. ${ }^{40}$ Feltehetjük a kérdést, hogy akkor a központi jogalkotás és általában szerepvállalás milyen mértékü kell, hogy legyen, hiszen az elöbbiekből pont az tünhet ki, hogy a központi szabályozás és hozzáállás hiányosságaira vezethető vissza a jelenlegi helyzet: vagyis hiába a stratégiaalkotásból (és azok megfelelő végrehajtásából) származó számtalan elméleti előny, a helyi szint láthatóan nem tudja kihasználni ezeket a lehetöségeket. ${ }^{41}$ Baják azt írja, hogy a külföldi szakirodalom a központi kormányzat szerepével kapcsolatban azon az állásponton van, hogy a helyi fenntarthatósági folyamatokkal a központi kormányzatnak foglalkoznia kell, azonban nem szabad a folyamatok irányítására törekednie, ez ugyanis oda vezethet, hogy a helyi erők érdektelenné válnak, a helyi kezdeményezések lendületet veszíthetnek. ${ }^{42}$ Így a központi kormányzatnak e kérdéseket óvatosan kell kezelnie, és bár Magyarországon úgy tünik, hogy nem áll fenn a veszélye annak, hogy pont a fenntarthatósági törekvéseket erőltetné a kormányzat - a szerepének arra kell korlátozódnia, hogy (pl. információ szolgáltatása, pénzügyi források biztosítása révén) megfelelő talajt biztosítson az alulról jövő kezdeményezéseknek.

A települések azonban nem várhatják a megváltást. Addig is, amíg központi szinten nem történnek olyan változások, amelyek segítenék a környezetvédelmi, fenntarthatósági törekvéseiket, maguknak kell megragadniuk a lehetőséget, esetleg társulhatnak más településekkel is ilyen célból, és megalkothatják saját fenntartható fejlődési, környezetvédelmi, illetve energiastratégiájukat. Belátható, hogy ez sok tervezést, figyelmet igényel, és a mindennapi ügyek forgatagába nehéz lehet beilleszteni a tervkészítésekkel járó

\footnotetext{
${ }^{39}$ BAJÁK (2007): i.m.,151-157.

${ }^{40}$ LuCAS, Karen-Ross, Andrew-Fuller, Sara: Local Agenda 21: When is it a model for joined-up community based activity? Centre for Sustainable Development, University of Westminister, 2001.

41 Lásd még RichARDSON, Benjamin (ed.): Local Climate Change Law. Environmental regulation in cities and other localities. IUCN Academy of environmental law series. Cheltenham, UK, 4-5.

${ }^{42}$ BAJÁK (2007): i.m.,153-154.
} 
feladatokat, azonban megéri. De csak egy esetben, - és ezt nem lehet eleget hangsúlyozni - ha nemcsak arról van szó, hogy készítsünk egy újabb stratégiát, hanem ha a stratégia készítői, komolyan bevonva a helyi társadalmat, valóban felmérik a település környezeti, energetikai helyzetét, és azok figyelembevételével tudatosan fogalmaznak meg célokat. E tudatosság nélkül a települések nem lesznek képesek Magyarországon hatékony és kreatív lépéseket tenni a fennálló problémák megoldására, csak sodródni fognak az árral, erősítve azt a hitet, hogy nem képesek egyedül boldogulni.

Önmagában a stratégiaalkotás nem oldja meg a problémákat, viszont úgy gondolom, hogy elengedhetetlen ahhoz, hogy a települések hatékonyan kezeljék saját környezeti, fenntarthatósági, energetikai kérdéseiket. Stratégiai háttér nélkül az önkormányzatok által e tárgykörökben alkotott jogszabályok is csak szabályok rendezetlen halmazai, amelyeket ide-oda módosítgatnak, minden hosszú távú, tudatos, holisztikus szemlélet nélkül. ${ }^{43}$

43 WhEELER, Stephen: Planning for sustainability. Contemporary concerns of planning, 111-117. http://ldachair.ucdavis.edu/LDA-facultydocs/SW/Local\%20Planning\%20LP\%20111-117\%20Wheeler.pdf (2016. 01.14.). 


\title{
ÖNKORMÁNYZATI TÁRSULÁSOK A HELYI KÖRNYEZETVÉDELMI FELADATOK ELLÁTÁSÁBAN
}

\author{
Barta Attila*
}

2016-os adatok alapján Magyarországon 3178 települési típusú önkormányzat, valamint 19 területi típusú önkormányzat múködik. ${ }^{1}$ A településeken belül meghatározóak a községek, amelyek a nevezett csoport $88 \%$-át adják. ${ }^{2}$ Ezek a mutatók rendkívül beszédesek. Az ilyen típusú, fragmentált önkormányzati rendszerekben az eredményesebb feladatellátás egyik lehetséges formája az, amikor az önkormányzatok közösen gondoskodnak azokról. ${ }^{3}$ Ahogy azt majd lentebb is látni fogjuk, a környezettel és annak védelmével összefüggő közigazgatási feladatok kiváló terepet jelentenek az ilyen típusú kooperációnak, településközi együttmüködésnek.

\section{A társulások mibenléte, típusai}

Ahhoz, hogy a témakörrel érdemben tudjunk foglalkozni, elsőként azt érdemes röviden tisztázni, hogy mi is az a közjogi intézmény, amit jelenleg társulásként értelmezünk. $\mathrm{Az}$ önkormányzat-önkormányzat közötti horizontális együttmüködések szabályozása nem a 21. század terméke. A magyar és nemzetközi közjogi joganyag is ismerte és alkalmazta már a 19-20. században,

* Dr. Barta Attila, PhD, egyetemi adjunktus, Debreceni Egyetem Állam- és Jogtudományi Kar. A munka a Nemzeti Kutatási, Fejlesztési és Innovációs Hivatal támogatásával készült, és a K 115530 ny. sz. „Helyi önkormányzati szerepek és eszközök az ökológiai fenntarthatóság megvalósításában” címü, jelenleg is folyó kutatás eredményeit tartalmazza.

1 Az adatok forrása az Önkormányzati Hírlevél 2016/5. számában található Önkormányzati Tudástár. Lásd:

http://www.kormany.hu/hu/dok? source=1\&type=301\#! DocumentBrowse

(2017. január 5.).

${ }^{2}$ Lásd a KSH adatait: https://www.ksh.hu/docs/hun/hnk/hnk_2015.pdf (2017. 01. 12.).

${ }^{3}$ SzABÓ György: A települési önkormányzatok környezetvédelmi feladatai. Debreceni Egyetem, Debrecen, 2008, 20. 
persze országonként és korszakonként eltérő mértékben. ${ }^{4}$ Mivel nehéz lenne olyan klasszifikációt kialakítani, ami kellő pontossággal mutatná be, hogy melyik állam, melyik idöszakban hova sorolható a társulások szempontjából, sokkal helyesebb, ha az ismert és alkalmazott megoldásokat vesszük alapul egy-egy elméleti skála kialakításához. Ezek szerint számos variáció honosodott meg az idők során, amelyek ráadásul nem feltétlenül egymást kizáró jelenségek, hanem vegyesen is létezhetnek egy-egy nemzeti közigazgatási rendszerben. ${ }^{5}$

A csoportosítás egyik lehetséges esetét a társulások létrejöttéhez kötjük. Az így kialakított elméleti skála egyik végén az önkéntes társulás, a másik végén a kötelező társulás intézménye helyezhető el. Miután azonban a települések együttmüködési hajlama rapszodikus, emiatt a gyakorlatban széles körben terjedtek el a különböző gazdasági ösztönzőkkel támogatott társulások, amelyek nem hordoznak kényszerelemet, helyette inkább pénzügyi eszközökkel igyekeznek motiválni az önkormányzatokat. Ez Magyarországon is bevett megoldásnak számított a 2010 -es évekig.

Másfajta eredményre vezet, ha a résztvevő önkormányzatok irányából közelítünk. Általánosságban elmondható, hogy a társulás lehetősége mind a települések, mind a területi típusú önkormányzatok számára adott. Értelemszerüen vannak olyan feladatok, amelyeket (pl. a lakosság számára legszükségesebb, mondhatni alapfokú szolgáltatásokat, pl. egészségügyi, szociális ellátásokat) vagy csak települések, vagy kifejezetten a területi önkormányzatok látnak el (sokszor a speciális szakértelem esetleg infrastruktúra miatt). Utóbbira szolgálhat példaként egy sajátos, társulásos jellegü intézmény, az ún. térségi fejlesztési tanács. ${ }^{6}$ Nyilván emiatt a potenciális együttmüködői kör is korlátozottabbá válhat. Hazánkban a korábbi önkormányzati törvény érezhetően a

\footnotetext{
${ }^{4}$ A dualizmus időszakában például a községekröl szóló 1886. évi XXII. tc. már rendelkezett a mai fogalmaink szerinti „hatósági igazgatási társulásokról,” amelyek mellett ebben az időszakban az orvosi és állatorvosi körök voltak elterjedtek. FOGARASI József-IVANCSICS Imre-KISS László: A helyi önkormányzatok. Unió, 2001, 232.

${ }^{5}$ A tipizálás alapját lásd: ÁRVA Zsuzsanna-BALÁZs István-BARTA Attila-VESZPRÉMI Bernadett: Helyi önkormányzatok. Debreceni Egyetemi Kiadó, Debrecen, 2014.

${ }^{6}$ Nagy Marianna-Hoffman István (szerk.): A Magyarország helyi önkormányzatairól szóló törvény magyarázata. HVG-Orac, Budapest, 2014, 311.
} 
nagyobb településtársulások kialakulását szorgalmazta, $^{7}$ így az önkormányzati alapszint számára változatos formákat és típusokat munkált ki a jogalkotó. Az új önkormányzati törvénnyel a társulási joganyag jelentékenyen átalakult, a társulási alakzatok száma lecsökkent. ${ }^{8}$

Végezetül megint másfajta csoportosításra jutunk, amennyiben a társulások célja alapján differenciálunk. Itt az egyik lehetséges véglet az ún. egycélú társulások köre. Ezek kizárólag valamilyen jól behatárolt feladat megvalósítására létesülnek, pl. óvoda fenntartása, területfejlesztési ${ }^{9}$ vagy hulladékgazdálkodási feladatok ellátása. A mérce másik végén a többcélú, azaz komplex társulások helyezkednek el. Kifejezetten ilyen volt hazánkban a 2004-ben intézményesített többcélú kistérségi társulás konstrukciója is. ${ }^{11}$ Utóbbi megoldás erőssége az, hogy nem kell az egyébként egymáshoz kötődő feladatokra külön-külön társulásokat létrehozni, ráadásul a szoros kapcsolatokat ápoló településcsoportok esetén sokkal intenzívebb együttmüködést tesz lehetővé.

A fenti típusok jellemzően együttesen szoktak megjelenni a nemzeti közigazgatásokban. Kétségtelenül az egyik legelterjedtebb esetnek az számít, amikor a települések olyan egycélú társulásokat alakítanak, amelyek önkéntes alapon, vagy ösztönzött módon szerveződnek. ${ }^{12}$ Azonban látni kell, hogy az elmúlt évtizedek egészen új kihívásokat hoztak felszínre, és új irányokat is vetítenek elöre. $^{13}$

Az egyik ilyen az elöregedö társadalmakat sújtja. Változatlan demográfiai folyamatok mellett az elkövetkező évtizedek egyik legkomolyabb problémája lehet több európai államban a depressziós, illetve periférikus térségek fokozatos elnéptelenedése. Érthető módon ez legközvetlenebbül az önkormányzati alapszintet, a

\footnotetext{
${ }^{7}$ FÜRCHT Pál: A településközi együttműködés egyes kérdései. Magyar Közigazgatás 2000/9, 533.

${ }^{8}$ Nagy-Hoffman: i.m., 309.

${ }^{9}$ A területfejlesztésről és területrendezésröl szóló 1996. évi XXI. törvény.

11 2004. évi CVII. törvény a települési önkormányzatok többcélú kistérségi társulásáról. ÁRVAI Tibor: Települési önkormányzatok együttmőködése, társulásos kapcsolatai, különös tekintettel a kistérségekre. Magyar Közigazgatás 2000/7, 421431.

12 További információkkal szolgál SOMLYÓDYNÉ PFEIL Edit: Önkormányzati integráció és helyi közigazgatás. Dialóg-Campus, Budapest-Pécs, 2003.

13 ÁrVA-BALÁZS-BARTA-VESZPRÉMI: i.m., 266-267.
} 
településeket érintheti, hiszen fel kell készülni arra, hogy adott esetben több kisebb közösségnek együtt kell gondoskodnia az önkormányzati feladatok jövőbeni ellátásáról. Ennek egyik lehetséges útja a települések fúziója, a másik a társulási rendszer megújítása.

Tekintettel arra, hogy az előbbiekkel szinkronban a városi és nagyvárosi közösségek viszont valószínűleg tovább fognak nőni, a másik komoly kihívást az agglomerációk és központjaik sokasodó szociális, kulturális, környezetvédelmi és szolgáltatási feladatai vetítik előre. Ezek sikeres kezelésének egyik lehetséges eszköze ugyancsak az önkormányzatok közötti horizontális együttmüködés, aminek egyébként már Magyarországon is felfedezhetőek a nyomai. A Fővárosi Agglomeráció Önkormányzati Társulás alapvető rendeltetése például a közös érdekérvényesítés, közös gondolkodás és tapasztalatcsere, többek között a közösségi közlekedés, közbiztonság, valamint a turisztika területén. ${ }^{14}$

Leszögezhető, hogy az elmúlt évtizedekben, különösen pedig a pénzügyi-gazdasági válság nyomán megváltozott az államhoz és a közigazgatáshoz való viszonyulás. Bár több olyan krízis is felütötte fejét a közelmúltban, amelyek államok széles körét hasonlóan érintik (így pl. klímaváltozás, terrorfenyegettség, illegális migráció), nem jelenthető ki egyértelműen, hogy minden ország azonos eszmeiség mentén hasonló utat jár be. Az bizonyos, hogy a korábban meggyengült állam és végrehajtó apparátusa szinte mindenhol megerősítésre kerül. ${ }^{15}$

Ez a folyamat a közigazgatás nagy alrendszerei között egyfajta belső átrendeződést indukál, a hangsúlyok egyértelmüen megváltoznak. Ennek jeleit Magyarországon az elmúlt évek intenzív átalakításai bizonyítják, amelyek homlokterében egy aktív és potens állam képe húzódik meg. ${ }^{16}$ A megújítási folyamat egyik fontos komponense a korábban hiányzó/elégtelen integratív kötőpontok kialakítása/fejlesztése a közigazgatásban. Tekintettel azonban arra, hogy a központi akarat gyors és hatékony megjelenítése elsősorban a

\footnotetext{
${ }^{14}$ http://www.faot.hu/a-tarsulasrol (2017. 01. 24.).

${ }^{15}$ BALÁzS István: A közigazgatás változásairól Magyarországon és Európában a rendszerváltástól napjainkig. Debreceni Egyetemi Kiadó, Debrecen, 241; G. FODOR Gábor-STUMPF István, Neoweberi állam és jó kormányzás. Nemzeti Érdek 2008/7.

16 http://magyaryprogram.kormany.hu/admin/download/8/34/40000/MagyaryKozigazgatas-fejlesztesi-Program.pdf (2017. 01. 24.).
} 
hierarchikus és centralizált szervezeti rendszereken keresztül realizálódik legkönnyebben, az adminisztratív átalakítások fókuszába az államigazgatás került.

A helyi önkormányzati rendszer újragondolása, mozgásterének lehatárolása is ebben a kontextusban valósult meg. $\mathrm{Az}$ önkormányzatokra vonatkozó közjogi szabályozás szakított a korábbi neoliberális megközelítéssel. A helyi önkormányzatokat egyértelmüen az államszervezeten belüli intézményekként pozícionálta, valamint az állam és az önkormányzatok között új feladatmegosztás alapjait rakta le. ${ }^{17} \mathrm{~A}$ változások eredménye egy szorosabban integrált rendszer lett, amelyben a helyi önkormányzati autonómia helyett nagyobb hangsúly helyeződik a hatékonyságra, racionalitásra, valamint eredményességre. ${ }^{18}$ Ezek tisztázása után lássuk, hogy mi a helyzet a társulásokkal!

\section{A hazai társulási rendszer jellemzői. Számok, példák}

Terjedelmi okokból kifolyólag a továbbiakban kifejezetten csak a hatályos rendszer bemutatását végzem el. ${ }^{19}$ Magyarország Alaptörvénye általánosságban valamennyi önkormányzat számára biztosítja a társuláshoz való jogot, amikor a Helyi Önkormányzatok Európai Chartájával összhangban a 32. cikk (1) bekezdés k) pontja szerint deklarálja a szabad tárulás elvét. Valamivel odébb ${ }^{20}$ ezt annyiban árnyalja, hogy - régi szakmai elképzelésnek eleget téve ${ }^{21}$ megteremti az ún. kötelező társulás lehetőségét, amikoris törvényi rendelkezés nyomán kell az önkormányzatoknak kötelező

\footnotetext{
${ }^{17}$ FÁBIÁN Adrián: Kommentár az önkormányzati törvényhez. Complex, Budapest, 2013, 31-32.

${ }^{18}$ Ennek a gondolatmenetnek részletes kifejtését adja NAGY-HoFFMAN: i.m., 35.

19 Az elözmények kapcsán lásd még SzABÓ Lajos: Az önkormányzatok társulásai. Magyar Közigazgatás 1994/3, 146-153.; SOMLYÓDINÉ PFEIL Edit: Az önkormányzati társulásokról a gyakorlattól a szabályozásig. Magyar Közigazgatás 1995/12, 691697.; PAJOR Pálné: Társulások az önkormányzati rendszerben. Comitatus: önkormányzati szemle 1996/9, 10-16.; FÜRCHT Pál: Az önkormányzati társulási törvényröl. Magyar Közigazgatás 1998/3, 151-157.; SOMLYóDINÉ PFEIL: Önkormányzati integráció és helyi közigazgatás i.m.; HofFMAN István: A helyi önkormányzatok társulási rendszerének föbb vonásai. Új magyar közigazgatás 2011/1, 23-33.

${ }^{20}$ Alaptörvény 34. cikk (2) bekezdés.

${ }^{21}$ Nagy-Hoffman: i.m., 33.
} 
feladataikról közösen gondoskodniuk. ${ }^{22}$ Az Alaptörvény szükségképpen szikár, lényegre törő rendelkezéseit a Magyarország helyi önkormányzatairól szóló 2011. évi CLXXXIX. törvény (röviden Mötv.) bontja ki a 87-95. §-okban.

Eltekintve most az önkormányzati törvény idevágó intézményeinek részletes tárgyalásától, vizsgáljuk meg azt, hogy miként írja körül a jogszabály a társulást! A Mötv. 87. §-a értelmében a helyi önkormányzatok képviselö-testületei megállapodhatnak abban, hogy egy vagy több önkormányzati feladat- és hatáskör, valamint a polgármester és a jegyző államigazgatási feladat- és hatáskörének hatékonyabb, célszerübb ellátására jogi személyiséggel rendelkező társulást hoznak létre. Ebből a körülírásból egyértelmü, hogy a társulás:

- a közjog által szabályozott együttmüködés,

- funkciója az önkormányzati feladat- és hatáskörbe tartozó ügyek tartós, közös kezelése, megoldása (pl. ivóvízminőség javítása, területfejlesztés, hulladékgazdálkodás, illegális szeméttelepek felszámolása, ha kifejezetten csak környezetvédelmi relevanciájú példákat akarunk nevesíteni),

- célja az erőforrások közös, optimális felhasználása a résztvevők egyenjogúságának tiszteletben tartása mellett, a kölcsönös elönyök és az arányos közteherviselés szem előtt tartásával. ${ }^{23}$

A magyar társulási joganyag - az állam és közigazgatás szerepkörének fent már röviden taglalt újragondolásával párhuzamosan $^{24}$ - 2013-ban kardinális változáson esett át. ${ }^{25}$ Általában elmondható, hogy a joganyag egyszerüsödött, ${ }^{26}$ aminek

22 Jelenleg ilyen kötelező (egyben atipikus) társulás a polgármesteri hivatalok közös múködtetése, az ún. közös önkormányzati hivatal konstrukciója.

${ }^{23}$ ÁRVA-BALÁZs-BARTA-VESZPRÉMI: i.m.

$24 \mathrm{http}: / /$ magyaryprogram.kormany.hu/admin/download/8/34/40000/MagyaryKozigazgatas-fejlesztesi-Program.pdf (2017. 01. 24.).

${ }^{25} \mathrm{Az}$ önkormányzatoknak 2013. június 30-ig kellett átalakítaniuk korábbi társulásaikat.

${ }^{26}$ BEKÉNYI József-GYERGYÁK Ferenc: A helyi önkormányzatok társulásairól szóló szabályozás változásai. Új magyar közigazgatás 2013/2, 68-69.; valamint NagyHoffman: i.m., 309. A teljes képhez hozzátartozik az is, hogy míg az Ötv. feladat alapú megközelítést követett, addig a Ttv. szervezeti alapú megközelítéssel élt. Emiatt a társulásoknak széles köre honosodott meg Magyarországon. 
hátterében az önkormányzati feladatrendszer módosulása húzódik meg. A 2010-es évek első harmadában Magyarországon megközelítőleg 1200 társulás működött. A társulások méreteit vizsgálva a legjellemzőbb a 3-5 tagú együttmüködések kialakítása volt, melyek jellemzően egycélúak voltak. Számos hulladékgazdálkodási, víziközmű fenntartásával foglalkozó, illetve területfejlesztési feladatok közös ellátására létesült társulás müködött a korábbi években is, amennyiben kifejezetten a környezetvédelmi kötődésűeket kívánjuk kiemelni. A többcélú társulások intézményesített formáját az ún. kistérségi társulások jelentették, természetesen környezetvédelmi relevanciájú feladatok felvállalására ezek is alkalmasak voltak. ${ }^{27}$ Napjainkban is elterjedtnek mondható a társulás intézménye, ugyanakkor a belső arányok érezhetően módosultak. 2015 végén, 2016 elején nagyságrendileg 1000-re rúgott a számuk, ami egyértelmü csökkenést mutat a korábbiakhoz képest. Bár továbbra is igen elterjedtek a 3-4-5 tagönkormányzatot számláló együttmüködések, nem ritkák a 30-40 tagú társulások (gyakran szociális területen), illetve van példa kifejezetten népes, akár 150200 önkormányzat együttmüködésével tevékenykedő társulásokra is (tipikusan a hulladékgazdálkodás területén, konkrét példákat később irunk is ilyenre). ${ }^{28}$

Amennyiben a társulások kapcsán eddig leírtakat röviden összegezni kívánjuk, kijelenthető, hogy az olyan szétaprózott település-struktúrával rendelkező országok esetében, mint amilyen a magyar is, a társulásokhoz hasonló együttmüködések képesek a feladatok hatékonyabb ellátását előmozdítani, mivel integratív eszközként funkcionálnak. A társulási szabályanyag változásának egyik oka a járások újbóli beüzemelése, hiszen korábban számos esetben a társulások olyan, államigazgatástól átruházott feladatok ellátására létesültek, amelyek 2013 után a járásokhoz kerültek. Emiatt napjainkra a társulások elsősorban (de nem kizárólagosan) az önkormányzatok saját feladatainak a megvalósításához szolgálnak eszközül.

\footnotetext{
27 További részleteket tartalmaz az Önkormányzati Tudástár, az Önkormányzati Hírlevél különszáma: „Amit az önkormányzatokról tudni érdemes. Önkormányzatok társulásai. 2014. január." Valamint GÁLOSI-KovÁCs Bernadett: A környezettudatos kistérségfejlesztés kérdései. Területfejlesztés és innováció 2009/4, 8-22.

${ }^{28}$ Az áttekintés alapját az Országos Statisztikai Adatgyüjtési Program (OSAP) 2015 végi, 2016 eleji adatai képezik.
} 
De melyek azok az önkormányzati feladatok, amelyek tipikusan ebbe a körbe sorolhatóak? - Tehetjük fel a kérdést az előző bekezdés záró mondatára reagálva. Habár a köztudatban ez nem mindig ismeretes, az önkormányzati társulások közül az egyik legelterjedtebb a közös önkormányzati hivatal konstrukciója. Ez lényegében egy atipikus (nem a többi társulás között szabályozott) ${ }^{29}$ intézmény, amely a hatósági igazgatási társulás kötelezően létrehozandó komplex alakzata (2015-ös adatok szerint országosan $739 \mathrm{db}$ müködött). ${ }^{30}$

A Mötv. azonban a 13. §-ban több, kifejezetten környezetvédelmi célzattal is bíró tevékenységet nevesít, így:

- településfejlesztés, településrendezés;

- településüzemeltetés (köztemetök kialakítása és fenntartása, a közvilágításról való gondoskodás, kéményseprö-ipari szolgáltatás biztosítása, a helyi közutak és tartozékainak kialakítása és fenntartása, közparkok és egyéb közterületek kialakítása és fenntartása, gépjárművek parkolásának biztosítása);

- környezet-egészségügy (köztisztaság, települési környezet tisztaságának biztosítása, rovar- és rágcsálóirtás);

- helyi környezet- és természetvédelem, vízgazdálkodás, vízkárelhárítás;

- honvédelem, polgári védelem, katasztrófavédelem, helyi közfoglalkoztatás;

- hulladékgazdálkodás;

- víziközmü-szolgáltatás, amennyiben a víziközmüszolgáltatásról szóló törvény rendelkezései szerint a helyi önkormányzat ellátásért felelősnek minősül.

A felsorolást lehetne még bővíteni, hiszen más törvények is meghatároznak ilyen típusú feladatokat, ${ }^{31}$ ugyanakkor a könnyebb

29 Ezzel egyezőleg lásd Nagy-Hoffman: i.m., 309., valamint részben azonos megközelítéssel FÁBIÁN: i.m., 241.

${ }^{30}$ Bács-Kiskun megyében 34, Baranyában 54, Békés megyében 21, Borsod-AbaújZemplénben 86, Csongrád megyében 14, Fejér megyében 29, Győr-Moson-Sopronban 47, Hajdú-Biharban 19, Hevesben 41, Jász-Nagykun-Szolnok megyében és Komárom-Esztergomban 21-21, Nógrádban 39, Pest megyében 27, Somogyban 57, míg Szabolcs-Szatmár-Bereg megyében kereken 60 hivatal müködik. Tolna Megyében 29, Vas megyében 40, és végül Veszprémben és Zalában 50-50.

${ }^{31}$ Erre szolgálhat jó példaként a helyi önkormányzatok és szerveik, a köztársasági megbízottak, valamint egyes centrális alárendeltségü szervek feladat- és hatásköreiről 
áttekintés érdekében egyelőre kifejezetten ezekre az elemekre koncentrálunk.

A településfejlesztés és -rendezés látszólag olyan feladat, ami minden önkormányzat belügye, emiatt pedig társulás alakítására alkalmatlan. Tekintettel azonban arra, hogy a helyhatóságok középés hosszú távú környezeti, gazdasági és társadalmi fejlesztési elképzelései ennek keretében fogalmazódnak meg, ráadásul számos esetben ez a környező településekre is kihat, müködnek ilyen társulások is, mint pl. „Rábcatorok” Településeinek Regionális Fejlesztési Társulása. ${ }^{32}$ A 18 település együttmüködését biztosító társulás alapvető célja, hogy a helyi közösségek egymást erösítve, a térségen belüli kapcsolataikat fejlesztve müködjenek. A helyi termékek támogatásán túl a partnerség értékleltárt müködtet, ahol a közös természeti örökségek - elsősorban vizes élőhelyek - is helyet kaptak. $^{33}$

A településüzemeltetés az előbbiekhez nagyon hasonló. Itt is vannak olyan szakigazgatási teendők, amiket a helyhatóságok egymással kooperálva végeznek el. Erre találunk példát a Mezőkövesdi Többcélú Kistérségi Társulás ${ }^{34}$ esetében is (egyébként a településüzemeltetési teendők tipikusan nem egycélú társulásoknál merülnek fel, hanem ilyen, többes rendeltetésű együttmüködések keretében). A résztvevő települések az állati hulladékok gyüjtésének és ártalmatlanításának közös szervezését, mint településüzemeltetési teendőt vonták a társulás égisze alá, ugyanakkor részben más területek is kapcsolódnak ide, úgymint a szennyvízcsatorna kiépítése, a 2000-es évek második felében a csapadékvíz-elvezetése és a kerékpárút-hálózat kiépítése.

Az Országos Statisztikai Adatgyüjtési Program információi szerint több olyan mikro-régió, illetve tájegység létezik, amelyik feladatának tekinti, hogy ne szegmentáltan, hanem a természet- és gazdaság-földrajzilag együvé tartozó települések közös fellépésével, összehangoltan rendelkezzen több, fent is nevesített önkormányzati feladatról. Főként turisztikai és gazdasági megfontolásokból a

szóló 1991. évi XX. törvény, vagy a természet védelméről szóló 1996. évi LIII. törvény.

${ }^{32} \mathrm{http}: / /$ rabcatorok.pannonhelyitermek.hu/projekt-bemutatasa (2017. 01. 24.).

33 http://rabcatorok.pannonhelyitermek.hu/ertekleltar/termeszeti-oroksegunk (2017. 01. 24.).

${ }^{34} \mathrm{http}: / /$ www.mezokovesd.hu/index.php?action=showmenu\&id=68 (2017. 01. 24.). 
Balaton környékének több települése is társulás keretében igyekszik rendezni környezet-egészségügyi, vízgazdálkodási, vízkár-elhárítási valamint helyi közfoglalkoztatással összefüggő feladatait (lásd pl. a Kelet-Balatoni Térség Önkormányzati Társulását). ${ }^{35}$

A környezet- és természetvédelem az esetek túlnyomó részében vagy a települési önkormányzatok egyéni tevékenysége keretében realizálódik, vagy többcélú társulásokon keresztül, ahol sokszor más tevékenységekhez kapcsolódva jelenik meg. A kifejezetten erre létrehozott egycélú társulás kiváló példája volt a 2016 decemberében - feladatok változása, valamint források hiányossága miatt megszüntetett Dél-Alföldi Regionális Környezetvédelmi Társulás, amelynek 17 tagtelepülése volt. A többcélú társulások kapcsán pedig a Tatai Kistérségi Többcélú Társulás említhető, amely azon túl, hogy összehangolja a kistérségi környezetvédelmi teendőket, együttmüködik az épített- és természeti környezet értékeinek megóvásában, valamint közremüködik a rehabilitációban. ${ }^{36}$

$\mathrm{Az}$ előbbiektől eltérően vannak olyan együttmüködések is, amelyek kifejezetten népesek, miután olyan üzemméretü közszolgáltatások hatékonyabb megszervezését célozzák, ahol a földrajzi lehatárolás (sokszor a korábbi kistérségi lépték) miatt eleve több önkormányzat érintett. Ilyen pl. a hulladékgazdálkodási társulás, amelynek egyik kiemelkedő példája lehet a Nyugat-Balaton és Zala Folyó Medence Nagytérség Települési Szilárdhulladékai Kezelésének Korszerú Megoldására Létrejött Önkormányzati Társulás. Ennek alapvető rendeltetése az, hogy komplex regionális hulladékkezelési közszolgáltatást biztosítson a 283 résztvevő önkormányzat számára, ami egy rendkívül nagy szám, ugyanakkor ha áttekintjük a résztvevő községek és városok listáját, jellemzően 500 fő alatti településeket találunk köztük (a társulási megállapodás szerint a legkisebb mindössze 15 lakossal rendelkezik). ${ }^{37}$ Hasonlóan népes a Kaposmenti Hulladékgazdálkodási Önkormányzati Társulás, amely 118 települést szolgál ki. A korszerü hulladék-feldolgozó üzem építése csak az egyik eleme annak a kombinált intézkedési

\footnotetext{
${ }^{35} \mathrm{http} / / /$ www.keletbalaton.hu/indexe37e.html (2017. 01. 24.).

36 http://www.tataikisterseg.hu/ter\%C3\%BCletfejleszt\%C3\%A9s-\%C3\%A9s-egyestelep\%C3\%BCl\%C3\%A9s\%C3\%BCzemeltet\%C3\%A9si-feladatok/173 (2017. 01. 07.).

37 http://banokszentgyorgykh.dokumentumtar.hu/dokumentumok/varfolde_2015_06_ 25_eloterj_2554_melleklet2.pdf (2017.01.24.).
} 
csomagnak, amely a somogyi lakosság egészségesebb életkörülményeit hivatott biztosítani. A hulladékkezelési központ nem szimpla hulladékudvarként funkcionál, hanem szelektív válogatócsarnok, valamint szigetelt hulladéklerakó tér is épül. Ezzel összhangban a társasházas övezetek hulladékgyüjtő edényeket kapnak, míg a családi házaknál a társulás ingyenes komposztládákat is kihelyez. ${ }^{38}$

Ugyancsak külön említést érdemel a víziközmü-szolgáltatásért felelős társulás konstrukciója. Jelenleg ilyen pl. a Baja és környéke Víziközmủ Beruházási Önkormányzati Társulás, amelynek alapvető célja a szennyvíz-agglomeráció keretében a 4 tagtelepülésen keletkező szennyvizek elvezetése, csatornázása és a víziközművek bővítése. $^{39}$ Hasonló a helyzet az 5 Heves megyei település szennyvízcsatorna-hálózatának és szennyvíztisztító telepének bővítése, korszerüsítése érdekében létesített Recsk és Térsége Víziközmű Beruházási Társulással. ${ }^{40} \mathrm{Az}$ elöbbi eseteken túl igen elterjedt volt korábban a talajvédelmi és vízvédelmi társulások alakítása. Mivel időközben az érintett jogszabályok jelentős változáson mentek keresztül, ez a fajta társulás kikopott a gyakorlatból, ami oda vezetett, hogy számos vízfolyás kezelése nem megoldott. Miután pedig az önkormányzatoknak sokszor nincs önereje az ilyen típusú feladatok ellátására, a kezeletlen vízfolyások könnyen árvízvédelmi veszélyforrást jelenthetnek.

Végezetül álljon itt egy érdekes példa. Bár viszonylag ritka, hogy települések között kifejezetten csak környezeti konfliktusokon alapuló, ún. ökológiai nézeteltérések alakuljanak ki, egyes esetekben vitarendezési fórumokként is funkcionálnak a társulások, minthogy a különösen kényes kérdések kapcsán lehetővé válik segítségükkel a lakosság folyamatos és összehangolt tájékoztatása. Erre kiváló példa lehet a Püspökszilágyi Radioaktív Hulladék Feldolgozó és Tároló ügye, ahol az érintett települések azért hoztak létre társulást, hogy ezzel képessé váljanak a biztonságnövelési munkák bemutatására, illetve az üzemeltetés biztonságának szemléltetésére és a lakosság bizalmának fenntartására. Jelenleg Izotóp Tájékoztató Ellenőrző Társulásként (ITET) müködik. Az ITET tevékenysége folyamatos, a

\footnotetext{
38 http://www.hirado.hu/2015/05/06/osztol-mukodik-a-kaposvari-uj-hulladekkezelesikozpont/ (2017. 01. 13.).

${ }^{39} \mathrm{http}: / /$ www.csatornazunk.hu/ (2017. 01. 10.).

${ }^{40} \mathrm{http} / / / \mathrm{www}$. szennyviz-recskterseg.hu/mt.pdf (2017. 01. 20.).
} 
legfontosabb információkat több csatornán keresztül osztja meg az érintettekkel. ${ }^{41}$

Rövid összefoglalásként megállapítható, hogy viszonylag ritka a kifejezetten helyi környezetvédelmi célokat szolgáló társulások megalakítása. A többcélú társulások keretében ugyanakkor már sokkal elterjedtebb az, hogy valamilyen, a környezetvédelem valamely sajátos szakterület felmerüljön. A tapasztalatok azt mutatják, hogy a fentieken túl az önkormányzatok szívesen társulnak vonalas létesítmények karbantartására ( $\mathrm{pl}$. a hulladékgazdálkodási rendszer koordinációja és projektgazdai feladatok ellátására), ${ }^{42}$ új beruházások kivitelezésére (pl. szennyvíztisztító telep építése), ${ }^{43}$ illetve új megoldások, jó gyakorlatok megosztására is (pl. helyes komposztálási gyakorlat bemutatása és támogatása, teljes körü, rendszeres szelektív hulladékgyüjtés gyakorlatának bevezetése).

\section{Határtalanul? - nemzetközi vonatkozások}

Globalizálódó (vagy már alapvetően globalizált?) világunkban a nemzeti szintet, az állami kereteket számos hatás éri, amelyek a határok fokozatos lebontását, légiesítését, az ún. határon átnyúló együttmüködések bővítését szorgalmazzák. Az ETT, vagyis az Európai Területi Társulás is egy ilyen eszköz, amely azonban nem tévesztendő össze a Mötv. társulási konstrukcióival, miután ez az európai uniós jog intézménye. ${ }^{44}$ És hogy mégis mire szolgál egy ilyen határmenti együttmüködés? Általánosságban (legalább két tagállamból) európai önkormányzatok transznacionális intézménye, amelynek célja uniós források hatékony felhasználása. Önálló, nonprofit jogi személy, amely eljárhat a tagok országaiban, adott esetben intézményeket és vállalkozásokat is létrehozhat és müködtethet.

Áttekintve a működő ETT-k körét, a számos cél között az egyik visszatérő és emiatt igen meghatározó éppen a környezetvédelem. A

41 http://www.rhk.hu/docs/kozvelemeny/ITT_zarotanulmany_2015.pdf (2017. 01. 24.).

${ }^{42}$ http://www.dunavertes.hu/node/2 (2017. 01. 24.).

${ }^{43}$ Lásd a Nagyatádi Regionális Szennyvíztársulás által elvégzett beruházást, amelynek köszönhetően nem csupán a szennyvíztelep biológiai kapacitása fejlődött, de az iszapkezelés korszerüsítése is megvalósult.

${ }^{44}$ A korábbi időszakra lásd az európai területi együttműködési csoportosulásról szóló 2007. évi XCIX. törvényt, majd utána a 2014. évi LXXV. törvényt az európai területi társulásról. 
szomszédos országok önkormányzataival kialakított kooperációk között van olyan, amely a környezetvédelem újkori feladatainak megoldására, a természeti erőforrások közös védelmére, a természeti kockázatok megelőzésére és a megújuló energiaforrások kiaknázására helyezi a hangsúlyt. ${ }^{45}$ A Banat-Triplex Confinium ETT a magyar-román-szerb hármas határ térségében jött létre a magyarországi (Bács-Kiskun és Csongrád megyei), a romániai (Temes megyei) és a szerbiai (vajdasági) települések és társulásaik tagságával. Az együttmüködés meglehetősen népes táboron alapszik, 37 magyarországi és 37 romániai önkormányzat közremüködésével látja el feladatait, valamint 8 szerbiai község is részt vesz a szervezet munkájában, mint megfigyelő tag. ${ }^{46}$

Müködik ugyanakkor olyan ETT is, amelynek alapvetö rendeltetése környezetgazdálkodási központ létrehozása és fenntartása, ahogy az az Ister-Granum ETT esetében is igaz, amely lényegében a magyarországi Esztergom és a szlovákiai Párkány vonzáskörzetét egyesíti. ${ }^{47}$ Azon túl, hogy Magyarországon ez volt az első, az Európai Unióban pedig a második bejegyzett határon átnyúló csoportosulás, érdemes még azt is tudni, hogy a korábbi években a közösség energiaügynökség létrehozását tervezte. Mivel ez források hiányában nem valósulhatott meg, jelenleg a résztvevő települések energiafelhasználásának csökkentésére törekszik az ETT. Ennek egyik tervezett módja biogázüzem létrehozása.

Más megfontolásokból alapították a Novohrad-Nógrád ETT-t ahol Salgótarján Megyei Jogú Város Önkormányzata és Fülek Város Önkormányzata müködik együtt. ${ }^{48}$ A szervezet egyezménye kifejezetten utal a fenntartható fejlödésre, valamint a természetés környezetvédelem fontosságára. Ehhez kapcsolódva többek között ún. Geoparkot müködtet, amely tagja a UNESCO égisze alatt múködő, Európai- és Globális Geoparkok Hálózatnak. A Geopark honlapja szerint 64 magyarországi és 28 szlovákiai településen kapcsolja össze a látványosságokat, kifejezett feladata pedig a terület földtudományi, táji, természeti, ökológiai, archeológiai, történelmi és

\footnotetext{
${ }^{45}$ http://www.btc-egtc.eu/images/BTC_EGTC/Alapaszably\%20uj\%202010.pdf (2017. 01. 25.).

${ }^{46} \mathrm{http}: / /$ www.btc-egtc.eu/hu/ (2017. 01. 25.).

${ }^{47} \mathrm{http}: / /$ istergranum.eu/ (2017. 01. 14.).

${ }^{48}$ http://nnegtc.eu/hu_HU/ (2016. 11. 12.).
} 
kulturális értékeinek megőrzése, bemutatása, geoturisztikai termékké formálása, ezáltal a helyi gazdaság fejlesztése. ${ }^{49}$

Az európai léptékű együttműködések kialakításának kiváló terepét nyújtják a folyók. A Rába-Duna-Vág Korlátolt Felelősségü Európai Területi Együttmüködési Csoportosulás érdekessége, hogy alapítói és csatlakozói nem települések, hanem nagyobb téregységek, így magyar oldalról megyék, míg a szlovák fél részéről kerületek (Győr-Moson-Sopron megye, Komárom-Esztergom megye, Pest megye, Nagyszombati kerület, Pozsonyi kerület). ${ }^{50} \mathrm{Az}$ együttmüködés olyan területekre terjed ki, mint az energetika, turizmus, oktatás, a Duna és mellékfolyóival kapcsolatos fejlesztések, valamint előbbiekkel szoros összefüggésben a környezetvédelem és mezögazdaság.

Végezetül ugyancsak kiemelhető az Ung-Tisza-Túr-Sajó EGTC. ${ }^{51}$ A szlovák-magyar-ukrán-román határ két oldalán elterülő különféle területi egységek és szervezetek közötti együttmüködés keretében több cél is megfogalmazásra került, ugyanakkor témánkat illetően a részes önkormányzatok a közös környezeti menedzsment fejlesztésére és a környezetvédelem elösegítésére is lépéseket tesznek. Ennek egyik érdekes példája a „Napenergia, - nap mint napenergia" elnevezésü mintaprojekt, amely új energiahasznosítási módszerek kidolgozását szorgalmazza a határmenti térségben.

Mint az a fentiekből is kiolvasható, az ETT nem a szó szoros értelmében vett társulás. Ugyanakkor logikájában nagyon hasonlít hozzá, mivel itt is olyan alulról jövő kezdeményezésről van szó, ahol mellérendelt felek közös és tartós feladatellátása valósul meg. A részes felek együttmüködésének különös jelentőséget ad a határokon átnyúló jelleg, ami különösen az ökológiailag és természetföldrajzilag egybefüggő területek esetén ad kiváló fogódzót a többnemzetiségü akciók megvalósítására. Nem meglepő, hogy éppen emiatt a környezet- és természetvédelem, vagy az energetikai kérdések sokkal tisztább formában jelentkeznek.

\footnotetext{
${ }^{49} \mathrm{http}: / /$ www.nogradgeopark.eu/ (2016. 11. 19.).

${ }^{50} \mathrm{http}: / /$ rdvegtc.eu/hu/tagok/ (2016. 12. 06.).

${ }^{51} \mathrm{http}$ ://egtc.kormany.hu/magyarorszagon-nyilvantartasba-vett-ett-k (2016. 11. 09.)
} 


\section{Záró gondolatok}

A fenti áttekintés nem lehet teljességre törekvő, miután a társulások száma még most is igen magas, ráadásul nem minden társulás bizonyul időtállónak. A halandóság okai között legtöbbször a fent már említett jogszabályváltozások, vagy más, például gazdálkodási, finanszírozási kérdések húzódnak meg. Azoktól az esetektől eltekintve, amikor a közjogi együttmüködés kifejezetten valamilyen beruházás megvalósítását és maximum annak fenntartását célozza, a stabil, tartós településeggyüttesek kialakulásának tipikusan már korábban is létezö, gazdasági, kulturális, esetleg földrajzi okai vannak. A fenti példák alátámasztják, hogy a környezetvédelem kedvez a több önkormányzat együttmüködésén alapuló hosszú távú kooperációk létrehozásának.

Az elöbbieket erösíti az a körülmény, hogy napjainkban a környezet-, a természet-, valamint a klímavédelem minden korábbinál szélesebb és hatékonyabb együttmüködést igényel(ne). ${ }^{52}$ A katasztrófavédelmi szervek mellett az önkormányzatok (és ezalatt nem csak a településeket, hanem a megyéket is érteni kell) szembesülnek elsőként - és akár tartósan is - az ökológiai, valamint klimatikus viszonyok átalakulásából fakadó hatásokkal, ennek megfelelően a helyi közösségek leginkább a helyhatóságoktól várják olyan problémák rendezését, amelyek sokszor messze túlmutatnak egy-egy önkormányzat (közigazgatási) határain és lehetőségein.

Településeinknek döntő többsége község, amelyek a hazai lakosság közel 1/3-ának szolgálnak lakhelyéül, ráadásul majdnem minden harmadik településünk 500 fő alatti lakosságszámmal bír (a községeken belül igen magas a kis lélekszámú települések aránya). Ez óhatatlanul oda vezet, hogy a kistelepülések önállóan, megfelelő humán és pénzügyi erőforrások hiányában nem képesek jelenlegi feladataikat teljeskörüen ellátni, és a hatályos jogszabályok adta lehetőségeket kihasználni. Eszközkészletük inkább szegmentáltnak mondható, ami elörevetíti, hogy nem a kérdések egyedüli rendezői, sokkal inkább a helyi partnerség és kooperáció előmozdítói, és

\footnotetext{
${ }^{52}$ A kutatás részleteit lásd: FODOR László-BARTA Attila-FÓNAI Mihály-BÁNYAI Orsolya: Települési környezetvédelem Magyarországon: Egy kutatás előfeltevései. Tér és Társadalom 2016/3, 19-39.
} 
maguk is nagyobb együttmüködésekben találhatják meg legkönnyebben helyüket és szerepüket. ${ }^{53}$

A társulás (és ugyanez értendő most az ETT-re is), mint közjogi intézmény alkalmas keretként szolgálhat ahhoz, hogy a települések adekvát válaszokat adjanak akár tágabb környezetüket érintő kérdésekre is. Mivel a Mötv. a legfontosabb szabályok tisztázásán túl rugalmas keretet biztosít, a helyhatóságok láthatóan szívesen élnek ezzel a lehetőséggel. ${ }^{54} \mathrm{Az}$ egy- illetve többcélú társulások változatossága természetesen függ az önkormányzatok együttműködési hajlandóságától, amit sokszor a pénzügyi helyzet, pályázati célok, esetenként jogszabályi kötelezés markánsan befolyásol. Kétségtelen, hogy továbbra is az önkéntesség a fószabály azzal, hogy a feladatellátásnak valamennyi esetben gazdaságilag és szakmailag is hatékonyabbnak kell lennie a korábbinál.

Az egyedi példák azt a célt szolgálták, hogy érzékeltessük, a 2010 után fokozatosan átalakult közjogi viszonyok között milyen tipikus (pl. csatornázási, többcélú), valamint szokásostól eltérő (pl. ITET, térségi fejlesztési tanács) együttmüködések lehetségesek önkormányzat és önkormányzat között. A kép változatos, szép számmal olvashattunk kreatív, akár követésre alkalmas megoldásokról is. Közszolgáltatások ellátására éppúgy szerveződnek társulások, mint ahogy közhatalmi feladatok is bevonhatók az ilyen típusú együttmüködések körébe.

Nincs ez másként az ETT-k esetében sem. A történelmi, kulturális, gazdasági és ökológiai kapcsolatokra alapozott transznacionális kooperációk számos ígéretes eredménnyel kecsegtetnek. Jó példái annak, hogy megfelelő összefogással nem csak az országhatárokon belül lehet környezetvédelmi kérdéseket felvállalni, ami különösen fontos, hiszen a természeti jelenségek sokszor nem követik az állami és közigazgatási határokat.

Azt is látni kell azonban, hogy önmagában a társulás sem csodaszer, nem alkalmas maradéktalanul bármilyen feladat

\footnotetext{
${ }^{53}$ Várhatóan ez a jövőben sem lesz másképp. A teljes kép megismeréséhez érdemes még megnézni:

http://www.kormany.hu/download/8/42/40000/K\%C3\%B6zigazgat\%C3\%A1s_feljesz t\%C3\%A9si_strat\%C3\%A9gia_.pdf (2017. 01. 05.)

54 HoFFMAN István: Új utak az önkormányzatok közötti együttmüködésben: a közszolgáltatások társulásos megszervezése. Tudományos közlemények 2012/27, 257 269.; FÁBIÁN: i.m., 241.
} 
ellátására. Az olyan kiterjedt társulások, mint amilyeneket a hulladékkezelési területen láttunk, nagyon komoly müködésbeli kihívásokat vetnek fel. Másfelől egyértelmü, hogy az ilyen típusú „mega-társulások” hiányában számos kistelepülés egyszerüen nem tudna bekapcsolódni elemi közszolgáltatások szervezésébe, beruházások megvalósításába. ${ }^{55} \mathrm{~A}$ lokális társulások kétségtelenül azokban az esetekben funkcionálnak legjobban, amikor olyan településcsoportok hozzák létre, amelyek közel azonos kérdésekkel találkoznak, ugyanakkor felismerik azt, hogy egymásra tekintettel sokkal jobban képesek a felmerülő kérdéseket kezelni. A Mötv. biztosítja ezt, miután egyértelműen a nagyobb, körzeti jellegủ közös feladatellátást pártolja a mikro-térségi együttmüködések helyett. ${ }^{56}$ Márpedig a természet- és környezetvédelem pont ilyen integratív, egyszersmind számos esetben nagyobb léptékben kezelhető terület. ${ }^{57}$

\footnotetext{
55 Továbbgondolásra érdemes lehet ezzel összefüggésben a nagyobb téregységben müködő területi önkormányzatok környezetvédelmi szerepe is.

${ }^{56}$ Nagy-Hoffman: i.m., 310.

57 A kérdés kapcsán további hasznos adalékokkal szolgál FoDOR László: Környezetjog. Debreceni Egyetemi Kiadó, Debrecen, 2014, 116.
} 


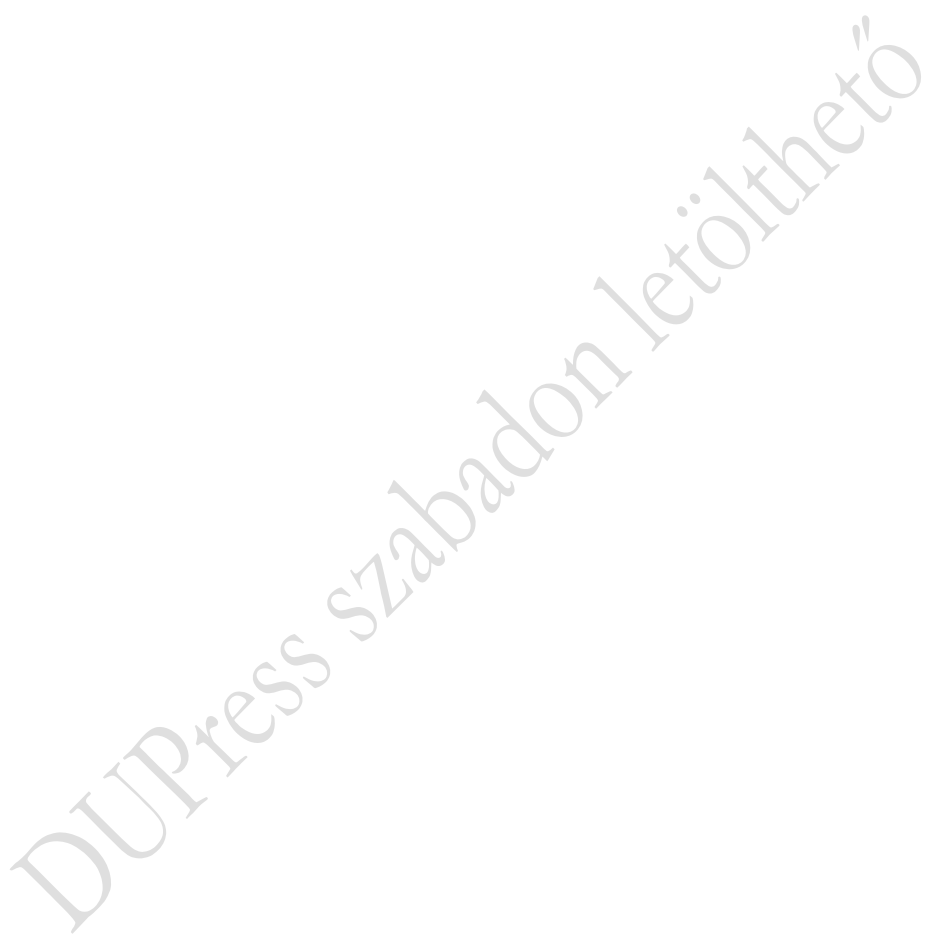




\title{
PARTNERSÉGI-E AZ EGYEZTETÉS? - A TELEPÜLÉSRENDEZÉSI ESZKÖZÖK NYILVÁNOSSÁGÁNAK KÉRDÉSEI EGY ESETTANULMÁNYON KERESZTÜL
}

\author{
Némedi Erika*
}

Az esettanulmány Alsónémedi - egy Pest megyei, 5000 lélekszámú település - önkormányzatának a helyi környezet minőségét, a helyi természetes és épített kulturális értékek megőrzését, a természeti erőforrások védelmét alapvetően meghatározó településrendezési eszközök egyeztetésével kapcsolatos tevékenységének az utóbbi 6 éves időszakát öleli fel - lakossági, civil megközelítésből. Az alább közölt információk az Összefogás a Jövőnkért Alsónémedin Egyesület első kézből származó ismeretei, amelyek az egyeztetéseken való részvétel során keletkeztek.

A település sajátos helyzetét fekvése adja. A főváros közvetlen szomszédságában található, közigazgatási területe egyfelől jelentős természeti értéket képviselő Natura 2000 területtel határolt területet, olyan nyílt víztükrü - müködö, felhagyott, illetve művelésre tervezett - bányatavak, illetöleg bányatelkek veszik körül, amelyek a térség ásványi anyag készletének kitermelését célozzák a következő évtizedekben. A Duna évezredekkel elötti munkájának köszönhetően ugyanezen a területen nem csak kavicshordalék rakódott le, hanem olyan lápi területek is keletkeztek, amelyeket a falu határában folytatott kisparcellás földművelés zárványokban olyan mértékben megőrzött, hogy közülük több felkerült az ex lege védett lápok listájára, így jelenleg több vizes élőhely is országos védettség alatt áll.

Környezeti szempontú megközelítésben a település problématérképének fókuszában ezért a víz és a termőföld, mellettük

\footnotetext{
* Némedi Erika az Alapvető Jogok Biztosának Hivatala munkatársa, Budapest.
} 
pedig - az uralkodó szélirányban fekvő főváros miatt - a levegő minősége áll.

A jövő generációk érdekeit tekintve lokálisan a leglényegesebb kérdés tehát: a természeti erőforrások kimerülésének, a levegőszennyezésnek, a vizes élőhelyek eltünésének veszélye, illetve a természetes élőhelyek diverzitásának csökkenése, párhuzamosan pedig a megélhetés biztosítása - a megfelelő minőségü életfeltételek hosszú távú megőrzése mellett. Ezeknek a problémáknak a jelen idejü kezelése azért is elkerülhetetlen, mert a változások, amelyek kellő odafigyelés nélkül a területen bekövetkeznek, bekövetkezhetnek, alapvetően formálják, determinálják, esetleg korlátozzák nem csak a jelenleg itt élő, de a következö nemzedékek jövőbeni perspektíváit is. Igenis tudomásul kell venni, hogy a jelenbéli döntések kihatnak a jövő nemzedék jövőjére is. Ezért alapvető jelentőségü az, hogy a helyben élők képesek legyenek befolyással bírni a jelenüket és jövőjüket meghatározó döntésekre. Mindennek két feltétele van: szükséges a jogszabály, mely ennek garanciáját biztosítja, másrészt szükség van a helybéliek aktivitására, hogy a számukra biztosított lehetőséggel érdemben éljenek.

Arra már korábban is jogszabályok biztosítottak garanciát, hogy különbözö, a környezetre hatást gyakorló eljárásokban az érintettek részt vehessenek, és a helyi érdeket a döntéshozatal során érvényre juttathassák.

Kérdés az, hogy a helyi lakosság - magánszemélyek és civil szervezetek - által becsatornázott érveket, javaslatokat az eljáró szerv milyen mértékben veszi figyelembe az adott döntés kialakításánál.

A másik kardinális kérdés, hogy azon a szinten, ahol a helyi környezetet érintő döntésekre érdemben lehet hatni, tehát a helyi döntéshozatali eljárás során - és ilyen, a település fejlődésének irányát hosszú távon meghatározó eljárás a településtervezés is - a helyi önkormányzat milyen minőségü kapcsolatot alakít ki a helybéliekkel, azok érdekérvényesítő csoportjaival.

Mindig van azonban egy esemény, amely a helyi közösséget aktivizálja, egy pont, amikor a csendes szemlélőböl aktív helyi állampolgár válik. 


\section{A közösségi cselekvést kiváltó esemény}

$\mathrm{Az}$ esettanulmányban szereplö település külterületén nem nagyüzemi termelés, hanem a hagyományoshoz közelálló, kisparcellás szántóföldi gazdálkodás folyt a múltban, és folyik jelenleg is. Ez a gazdálkodási forma a természeti tartalékokat kevésbé éli fel, a természetes állapotban visszafordíthatatlan változást kevésbé generál.

Egy bányavállalkozó célja viszont a 2007-ben indult hatósági eljárásban egy ilyen, mintegy 200 ha jó minőségü, kisparcellás mezőgazdasági művelés alatt álló, zöldségtermesztési célt szolgáló földterület kavics- és sóderbánya céljára, 100 éven keresztüli, külfejtéssel, illetve víz alóli kitermeléssel történő igénybevétele volt. A tevékenység nyilvánvalóan visszafordíthatatlan folyamatot generált volna az érintett területen. A helyi gazdálkodókban tudatosult, hogy a bányamüvelés idővel eltüntetné a számukra addig ismert tájat, megsemmisítené a vizes élőhelyeket, turjánokat, lápokat, a mezőgazdasági termelést pedig azonnal megszüntetné.

A helybéliek maroknyi csoportja - okulva a környezö települések ismert példáiból is - idejében felismerte azt, hogy a helyben hagyományos mezőgazdasági tevékenység és a megmaradt természeti értékeik egyaránt veszélybe kerülnek, ha intenzív bányászati tevékenységet kezdenek a falu külterületén. Több találkozás és némi útkeresés után kifejezetten úgy döntöttek, bejegyzett szervezetként lépnek fel a település természeti és épített értékeit, hagyományait, versenyképességét veszélyeztető tevékenységgel szemben, miután nyilvánvalóvá vált, hogy a helyi földterületek igénybevételével kapcsolatos, a környezetvédelmi, természetvédelmi és vízügyi hatóságnál, illetve a bányakapitányságnál folyó hatósági eljárásokba úgy tudnak bejelentkezni, és a tervezett tevékenységgel kapcsolatosan, az eljárás részeként eredményesen észrevételt tenni, ha ezt nem magánszemélyként, hanem egyesületként teszik.

A kezdetben civil összefogás 2008-ban vált egyesületként bejegyzett civil szervezetté, és ettől fogva már nem ad hoc jelleggel, magánszemélyekként, hanem tudatosan - figyelve minden, a település területét érintő eljárást - egyesületként léptek fel a helyi környezetkárosító tervek ellen. 
A gyakorlatban ez azt jelentette, hogy ha például egy gazda földterülete érintett volt egy bányászattal kapcsolatos hatósági eljárásban, azt valamelyik egyesületi tag felé jelezte. A hatósági eljárásba való bejelentkezés eleinte ezt követően történt meg. Az észrevételek előkészítése során az egyesület részéről közremüködők a bányák tervezett területét helyrajzi számról helyrajzi számra egyeztették, s ha kellett, az érintettekkel a helyszínen is ellenőrizték. Három év alatt az egyesület tucatnyi hatósági eljárásba jelentkezett be ügyfélként, nyújtott be beadványt a bányakapitánysághoz, a környezetvédelmi, természetvédelmi és vízügyi hatósághoz, illetőleg élt fellebbezéssel a főfelügyelöségnél.

A helyi civil szervezetet életre hívó bányahatósági ügy esetében az egyesület beavatkozóként, egy országos környezetvédelmi civil szervezet oldalán a bírósági szakban is képviselte a helyi közösség érdekeit. A bíróság ezt a pert végül megszüntette, a 200 hektáros területen pedig a helyiek mind a mai napig élelmiszert termelnek, föleg a főváros ellátására. Az említett három év alatt meggyökeresedett egy olyan civil együttmüködés, amely már nem megkerülhető.

\section{A lakossági vélemény hatósági eljárásokba történő becsatornázásának gyakorlata}

2010-ben az események felgyorsultak, szignifikánsan megnövekedett az eljárások száma: öt új, a településre tervezett bányanyitási, illetve kutatási kérelemre indult eljárásba kellett a helyi környezetvédelmi szervezetnek bejelentkeznie és észrevételt tennie.

A hatósági eljárásokban benyújtott fellebbezésekben, észrevételekben az egyesület rendszeresen hivatkozott a helyi építési szabályzat (továbbiakban: HÉSZ) azon szakaszára, amely korábban úgy rendelkezett, hogy a község területén bányatelek-fektetés és bányanyitás nem engedélyezhető. Ezt a rendelkezést 2009-ben az önkormányzat képviselőtestülete módosította. Az akkori polgármester testületi ülésen kifejtett érvelésében ezzel összefüggésben azt hangoztatta, hogy az Alkotmánybíróság eljárást indított a HÉSZ-ben rögzített, bányanyitásokat általánosan tiltó szabályok miatt, ezért van szükség a módosításra. Bár hivatalos információ nem volt, úgy lehetett tudni, az $\mathrm{AB}$ eljárása egy bányavállalkozó alkotmányjogi panasza alapján indult. Az ezzel 
kapcsolatosan született $\mathrm{AB}$ határozatról a helyieknek nem volt tudomásuk, az egyesület erről tájékoztatást közvetlenül nem kapott.

A HÉSZ változtatásra ekkor - a jegyzői előterjesztés szerint magasabb rangú jogszabály módosítása miatt volt szükség. Ezt az egyesület nem is vitatta. A módosítás szövegezését kifogásolta amiatt, mert álláspontjuk szerint az - az eredeti jogalkotói szándékkal szemben - többféleképpen is értelmezhető volt. Az önkormányzathoz eljuttatott beadványban a helyi civil szervezet a jogbiztonság Alkotmányban rögzített alapelvére hivatkozott, amely megköveteli, hogy a jogszabály - így a helyi rendelet - szövege értelmes és világos legyen, a jogalkalmazás során felismerhető normatartalmat hordozzon. Kérték, hogy a HÉSZ módosítás tegyen eleget ennek az alkotmányos követelménynek, rámutatva arra, hogy a hatályos szabályozás eltérő értelmezése lehetséges, ami jogbizonytalanságot eredményez. Az egyesület az egyértelmü szövegezésre javaslatot is tett. A kezdeményezésben arra is felhívták az önkormányzat figyelmét, hogy az időközben ex lege, azaz törvény erejénél fogva védetté váló jelentős természeti területeket is indokolt a HÉSZ-ben azok között a területek között felsorolni, ahol bányát nyitni semmilyen körülmények között nem lehet. Úgy ítélték meg ugyanis, hogy a megmaradt természeti értékek védelme ugyanolyan fontos, mint az, hogy meghatározott - a HÉSZ módosításában taxatíve felsorolt - területeken ne lehessen bányát létesíteni.

A 2010. évi választásokat megelőzően az önkormányzat polgármestere levélben kereste meg az egyesületet, véleményt kérve a HÉSZ vitatott szakaszának szövegszerüen megküldött módosításához. Ebben tájékoztatást adott arról is, hogy az épített környezet alakításáról és védelméről szóló 1997. évi LXXVIII. törvény (Étv.) 9/A. § értelmében a 9. § (3) bekezdés szerinti véleményeztetést el kívánják hagyni. A hivatkozott rendelkezés szerint az elkészített helyi építési szabályzatot és településrendezési terveket jóváhagyás előtt a polgármesternek véleményeztetnie kell a külön jogszabályban meghatározott közigazgatási, az érintett települési önkormányzati és az érdek-képviseleti szervek mellett a társadalmi szervezetekkel is, amelyek 22 munkanapon belül adhatnak írásos véleményt.

$\mathrm{Az}$ egyesület - a polgármester megkeresésében megadott 15 napon belül - véleményét megadta, egyúttal jelezte, hogy kezdeményezi azon helyi természeti élőhelyek, értékek védetté 
nyilvánítását, amelyek nem kerültek az ex lege (országosan) védett területek közé.

A HÉSZ módosítás ügyében az egyesület részvételével tartott egyeztető tárgyalás alatt érkezett meg az állami fópítész állásfoglalása, melyben a fóépítész jelezte, hogy a jogszabály a helyi építési szabályzat és módosítása készítését településtervezési jogosultsághoz köti.

A rendelet módosításának folyamatát megszakította a 2010. évi önkormányzati választás. Az újonnan megválasztott képviselőtestület a HÉSZ felülvizsgálata mellett döntött, jogosult tervezők bevonásával.

\section{Egy kezdeményezés sikere a partneri kapcsolat fokmérője?}

Tekintettel arra, hogy a HÉSZ a védett természeti területeket teljes körüen nem tartalmazta, az egyesület - a HÉSZ felülvizsgálattal párhuzamosan - a természet védelméről szóló 1996. évi LIII. törvény (Tvt.) 25. § (1) bekezdése alapján kezdeményezte az önkormányzat képviselőtestületénél, hogy a turjánvidékhez tartozó, országos jelentőségü védettség alatt nem álló területeket minősítse helyi jelentőségü védett területté, és a természetvédelem helyi szabályainak megállapításával helyi önkormányzati rendeletben mondja ki a község helyi jelentőségü természeti területeinek és értékeinek védetté nyilvánítását.

Miért volt erre szükség? Különösen azért, mert az egyesület azt tapasztalta, hogy bányakutatásra, valamint a bányanyitás, illetve bővítésre irányuló hatósági eljárásokban ebben az időszakban a jegyző - a hatóságok honlapjain hivatalosan közzétett határozatok tanúsága szerint - nem nyilatkozott a helyi természetvédelmi területeket illetően, annak ellenére, hogy a település jegyzője ekkor építésügyi hatósági jogkörrel ugyan nem rendelkezett, de a jogszabályok szerint az eljárásokban természetvédelmi hatóságként müködött közre. Példaként: egy 2010. évi, a környezetvédelmi, természetvédelmi és vízügyi hatóságnál folyó eljárásban a jegyző a következőképpen fogalmazta meg észrevételét: ,, a kijelölt területek közül néhány az országos ökológiai hálózathoz tartozik, néhány pedig tervezett helyi jelentöségü védett természeti terület besorolás alatt áll." Nem történt meg az érintett helyi védettség alatt álló 
természeti területek lehatárolása, elmaradt a védettséget biztosító jogszabályra való hivatkozás is. Ehelyett volt szükséges az egyesületnek az adott hatósági eljárásban benyújtott észrevételében megfogalmaznia mindazokat az érveket, amelyek természetvédelmi szempontból is megalapozták a bányászati tevékenység távoltartását az adott területtől.

Az egyesületi kezdeményezésre 2010. szeptemberében az önkormányzat végül úgy döntött, hogy felülvizsgálja a védendő természeti értékeket, majd azok meghatározása és elhelyezkedésük pontos megjelölése után megerősíti védettséget, és ezen területek vonatkozásában a szükséges kezelési tervet kidolgoztatja. Ennek azért van rendkívüli jelentősége, mert a bányászati tevékenység a védett természeti területtel összeegyeztethetetlen, jogszabály szerint kivett területnek minősül.

Nem vitatva, hogy a természetvédelmi területek helyi védettségét szabályozó rendelet előkészítése hosszadalmas eljárás, az egyesületnek mérlegelnie kellett azt a kockázatot is, ami a folyamatban lévő bányakutatási, illetőleg bányanyitási eljárások miatt fennállt. A természeti területek védettségét korábban rögzítő jogszabály a dereguláció miatt hatályon kívül került. Számolva azzal, hogy a területeket jog aktívan nem védi (nincs hatályos önkormányzati rendelet és kezelési terv) a település jegyzöjénél kezdeményezte az egyesület, hogy határozatával haladéktalanul nyilvánítsa ideiglenesen védetté a kezdeményezésében megjelölt területeket. A jegyző hiánypótlásra hívta fel az egyesületet, majd miután az egyesület a hiánypótlásnak nem tudott eleget tenni, a jegyző az eljárást megszüntette. Ezt követően fordult az egyesület a környezet-, és természetvédelemért felelös államtitkárhoz, aki a helyi jogszabály megalkotásáról - határidő kitüzésével - kért tájékoztatást.

$\mathrm{Az}$ önkormányzat ad hoc bizottsága által létrehozott munkacsoport az egyesület képviselöjének részvételével többször bejárta a település külterületét a helyi természetvédelmi oltalomra érdemes területek felkutatása érdekében, majd a területek megjelölésével tett javaslatot a védelmükre. Ebben a munkában az egyesület tagjai aktívan részt vállaltak, szakértőkkel, botanikusokkal, rovarászokkal többször, rendszeresen bejárva a területeket.

Az önkormányzat a helyi rendeletet 2011-ben nem tárgyalta. A képviselőtestület 2012. évi munkatervében természeti területek helyi védettségével kapcsolatos napirend nem szerepelt. A 2012 
februárjában tartott testületi ülésen elhangzottak szerint a polgármester rendelkezik a védendő területek térképével, és a területek kigyüjtése folyamatban van. Végül csak egy újabb, sürgető kezdeményezésre, 2012 decemberében fogadta el az önkormányzat a helyi természeti értékek védelmét biztosító rendeletet. Mindeközben számtalan levélváltás, a területek egyeztetése, és föleg parázs vita zajlott az önkormányzat és az egyesület között.

\section{A Helyi Építési Szabályzat egyeztetése}

Az esettanulmányban szereplö önkormányzat képviselőtestülete 2011-ben tehát a településszerkezeti terv módosításáról döntött. A Kormányhivatal törvényességi felhívására ezt a határozatot azonban néhány hónappal később módosítaniuk kellett.

2012. januárjában a polgármester írásban tájékoztatta az egyesületet, hogy a település teljes közigazgatási területére vonatkozóan a településszerkezeti terv, a szabályozási terv és a helyi építési szabályzat felülvizsgálatához az Étv. 9. § (2) bekezdése szerinti eljárást elindította, és ehhez az előzetes véleményüket kérte.

$\mathrm{Az}$ egyesület mindenekelőtt elektronikusan, írásban arra kért választ az önkormányzattól, hogy az aktuális HÉSZ tervezet egyeztetése pontosan mikor kezdődött. Válasz hiányában azonban az alapkérdést is megerősítve - az információs önrendelkezési jogról és az információszabadságról szóló 2011. évi CXII. törvény (Infotv.) 26. § (1) bekezdése alapján igényelték a HÉSZ egyeztetésével kapcsolatosan keletkezett iratokat, dokumentumokat, munkarészeket.

Ezután közel két éves huzavona kezdődött. Ez az időszak felvonultatta azokat az akadályokat, amelyek leküzdésére a civil szervezetnek újabb és újabb képességeket kellett kifejlesztenie, amennyiben el akarta érni eredeti célját: a közösségi érdek képviseletét az önkormányzatnak a szükebb és tágabb környezetet minőségében érintő döntéseiben.

\section{A társadalmi részvétel helyi szabályozásának hiánya}

Az első volt a sorban az egyeztetés a - környezetvédelmi tárgyú - helyi rendeletek előkészítésekor. A társadalmi egyeztetés kereteinek kialakítása érdekében korábban a helyi önkormányzatokról szóló 1990. évi LXV. törvény 103/B. §-a 
hatalmazta fel a helyi önkormányzat képviselőtestületét arra, hogy a helyi sajátosságoknak megfelelően, az általa megalkotott rendeletek elökészitésében való társadalmi részvétel szabályait rendeletben állapítsa meg. Az esettanulmányban szereplö önkormányzat esetében erre nem került sor. Ez végső soron azt eredményezte, hogy az önkormányzat a nyilvánosságot, lakosságot és a civil szerveződést egyaránt megfosztotta attól, hogy a helyi életviszonyokra legerősebb befolyással bíró önkormányzati rendeletek elökészítésében részt vegyen, véleményt nyilvánítson, illetve erre eseti jelleggel, külön érvelés felvezetésével kerülhetett csak sor, ami számtalan nézeteltérésre adott okot, végső soron el is mérgesítette a helyi önkormányzat és az adott helyi civil szervezet viszonyát.

Az önkormányzatok a szervezeti és müködési szabályzataikban (SZMSZ) jelölik ki azt a kört, amelynek tagjai tanácskozási joggal vehetnek részt a testületi üléseken. Az esettanulmányban szereplö civil szervezetet a helyi önkormányzat SZMSZ-e szerint tanácskozási jog a településfejlesztési bizottság, illetve a képviselötestület ülésén környezeti ügyekben sem illette meg. $\mathrm{Az}$ egyesületnek az üléseken jelen lévő képviselője a környezetet érintő témákban is csak közvetlenül a szavazás előtt kapott szót, akkor, amikor a polgármester a vitát már lezárta, tehát a lakossági vélemény a döntést érdemben már nem befolyásolta. Ez a gyakorlat a helyi civil érdekérvényesítést kiüresítette, formálissá tette, ezzel az önkormányzat a jogalkotó eredeti szándéka szerinti előírását megkerülte.

Részt venni a helyi döntések megformálásában abban az esetben lehet, ha az állampolgárok értesülnek róla. Az esettanulmányban szereplő helyi önkormányzat SZMSZ-e szerint 3 nappal az ülés elött kellett kiküldeni a bizottsági meghivót, és a testületi ülést egy héttel később tartották. Nyilvánvalóan szükös időkeret ez a lakossági vélemények összegyüjtésére és az egyesületi vélemény megfogalmazására. (Viszonyításként az esettanulmányban szereplő civil szervezet a környezetvédelmi koncepcióhoz például több mint 20 oldalas, részletes véleményt készített.)

Véleményt formálni csak arról lehet, amit a helyi lakosság ismer. $\mathrm{Az}$ egyesület - ugyanúgy, ahogyan a helybéliek - az esettanulmányban áttekintett időszakban meghívóval kizárólag a bizottság és a képviselötestület üléseinek a napirendjéről kapott tájékoztatást. Elöterjesztést ebben az időszakban egyikhez sem 
csatoltak. Az elöterjesztésekkel kapcsolatosan a képviselőtestület ülésén a civil szervezet képviselöjének kérdésére a jegyző azt a választ adta, hogy az SZMSZ nem írja elő az előterjesztések, mint munkaanyagok nyilvánosságát. Pusztán az ülések meghívói alapján azonban nem lehet az érintett helybéliekkel egyeztetni, és megalapozott, érdemi véleményformálással felkészülni az önkormányzati ülések helyi környezetre hatást gyakorló döntéseire.

A meghívóhoz csatolt előterjesztés megküldésétől el lehetett volna tekinteni, ha az elöterjesztéseket közzétették volna az önkormányzat honlapján. De ez sem történt meg. A jegyző ezzel kapcsolatos válasza - szintén az önkormányzat ülésén - az volt, hogy a honlapra az elkészült és hitelesített jegyzökönyv, az elfogadott határozatok és rendeletek kerülnek fel, mint közérdekü adatok.

Volt példa arra is, hogy környezeti témájú koncepció tárgyalásakor az egyesület képviselője a jegyzőtől az adott ülésen kapta meg az éppen megvitatás alatt lévő program egy vaskos példányát. Azt is az ülésen sikerült „kialkudni,” hogy a koncepció kerüljön ki az önkormányzat hivatalos honlapjára, hogy azt a lakosság megismerhesse és véleményezhesse.

$\mathrm{Az}$ információs önrendelkezési jogról és az információszabadságról szóló törvény (Infotv.) az elektronikus közzétételi kötelezettségröl világosan rendelkezik, amikor - az esettanulmány idején hatályos - 33. § (3) bekezdésében kimondja, hogy a (2) bekezdésben nem szereplö közfeladatot ellátó szervek a 37. § szerinti elektronikus közzétételi kötelezettségüknek választásuk szerint eleget tehetnek saját, társulásuk, felügyeleti szervük, valamint az erre a célra létrehozott központi honlapon való közzététellel. A törvény 1. számú mellékletében közölt általános közzétételi lista II. fejezetének 8., 9., és 10. pontjai tételesen felsorolták, hogy pontosan milyen adatokat kell az adatfelelösnek közzétennie. Ezek között szó szerint szerepelt, hogy a törvény alapján közzéteendő jogszabálytervezetek és kapcsolódó dokumentumok; a helyi önkormányzat képviselö-testületének nyilvános ülésére benyújtott előterjesztések a benyújtás időpontjától közzéteendők.

$\mathrm{Az}$ Infotv. közérdekü adatok elektronikus közzétételének részletes szabályait megállapító végrehajtási rendelete úgy rendelkezik, hogy a saját honlapon közzétevő közzétételi kötelezettsége teljesítésének szabályait közzétételi szabályzatban 
állapítja meg. Az esettanulmány által felölelt időszakban az önkormányzatnak volt hivatalos honlapja, azonban megkerülve a jogszabályt az önkormányzat a saját honlapján a külön törvényben megszabott adatok közzétételét, és a közzététel rendjének közzétételi szabályzatban történő rögzítését is mellőzte.

Az esettanulmányban áttekintett időszakban az SZMSZ szerint az önkormányzat hirdetőtábláján kellett kifüggeszteni a közzéteendö anyagokat. Az önkormányzat hivatalos helyiségében elhelyezett hirdetőtáblát azonban csak munkaidőben lehet megtekinteni, ezért annak megismerhetősége a munkába járó helyi lakosság számára korlátozott volt.

Egy-egy elöterjesztés tehát csak a polgármesteri hivatalban, a munkaidővel egybeeső ügyfélfogadási időben volt megtekinthető az adott időszakban. Az Infotv. rendelkezéseivel ellentétesen nem volt bárki számára biztosított a testületi előterjesztés megismerése, az adott jegyzőkönyvet és a hozzátartozó előterjesztést minden alkalommal személyesen kellett kikérni, melynek következtében nem érvényesült a jogszabály személyazonosítás nélküli kitétele sem.

A környezetet érintő adatok, önkormányzati dokumentumok hozzáférhetősége, pontosabban hozzáférhetetlensége emiatt már korlátozta a közérdekü adatok megismerhetöségét is.

A honlapról hiányzó, kötelező közzétételi körbe tartozó anyagokat az egyesület az esettanulmányban szereplő időszakban rendszeresen közérdekü adatként kérte ki, így volt csak lehetséges a dokumentumok megismerése, és a környezetet érintő döntések tervezeteinek véleményezése. Az egyesület gyakori közérdekü adatkérései azonban fokozták a konfliktust.

A településrendezési eszközök felülvizsgálata során elmaradt egyeztetés okán az egyesület a kormányhivatalnál eljárást kezdeményezett a társadalmi egyeztetés mellőzése, a Partnerségi Szabályzat hiánya miatt.

Végül 2014-ben a képviselőtestület úgy döntött, hogy a HÉSZ módosítását és felülvizsgálati eljárását nem folytatja tovább, a megindult eljárást megszünteti.

Az újabb választások utáni első ülések egyikén az új összetételü képviselőtestület a településtervezési eljárást megszüntető határozatot visszavonta. Ezt követően került ki az önkormányzat honlapjára egy új szövegezésű HÉSZ rendelet, és egy új településszerkezeti terv tervezete. Tehát ezúttal a település teljes 
területét érintő, új településrendezési eszközök alkotását határozta el az önkormányzat.

Az önkormányzat ebben a tervezési eljárásban 2015. februári határnapot jelölt meg a lakosság számára véleményének benyújtására.

Erről az eljárásról, a rendelet előkészítéséről a lakosság nem kapott tájékoztatást, abba az egyesületet sem vonták be. Csupán az elözetes tájékoztatást és a térképi részek aktuális változatát tette közzé honlapján az önkormányzat.

\section{A környezeti értékelés eljárásának kiüresítése}

A településrendezéshez kapcsolódó környezeti értékelésre vonatkozó eljárásról szintén nem volt tájékoztatás, nem volt egyeztetés.

A környezeti értékeléssel összefüggésben a törvény kifejezett jogokat biztosít a civil szervezet számára. A Kvt. 43. (6) bekezdése alapján a környezeti vizsgálat kiterjed a környezeti értékelés készítésére, és az érintett nyilvánosságtól észrevétel kérésére, ezek eredményeinek a terv kidolgozása során történő figyelembevételére, a terv elfogadásáról való tájékoztatásra, amiért a terv kidolgozója, illetve program elfogadója felelös. A környezeti értékelést - a településrendezési eszköz tervezetéhez hasonlóan - véleményezésére meg kell küldeni az érintett környezetvédelmi szervezeteknek, az eltérő véleményeket pedig - az érdekképviseleti és társadalmi szervezetek bevonásával - megbeszélés keretében egyeztetni kell.

A településrendezési eljárás környezetvédelmi követelményeivel foglalkozó ombudsmani jelentés ${ }^{1}$ úgy érvel, hogy bár az Étv. külön nem szabályozza, az egyes tervek, illetve programok környezeti vizsgálatáról szóló $2 / 2005$. (I. 11.) Korm. rendelet (a továbbiakban: SKV rendelet) 4 . $§(1)$ bekezdése $^{2}$ szerint a környezeti vizsgálati kötelezettség megállapításáról minden esetben egyedi képviselötestületi döntést kell hozni, amelyröl, valamint indokairól

\footnotetext{
${ }^{1}$ Az AJB-845/2012. számú jelentés, Budapest, 2012. augusztus 23.

${ }^{2} \mathrm{SKV}$ rendelet ,4. $\S$ (1) Az 1. $\S$ (3) bekezdés szerinti terv, illetve program megvalósitása várható környezeti hatásának jelentöségét a 2. számú mellékletben foglalt szempontok és a (2) bekezdés, valamint az 5. $\S$ (1) bekezdésében foglalt rendelkezések figyelembevételével kell eldönteni."
} 
tájékoztatni kell a nyilvánosságot, beleértve az érintett környezetvédelmi szerveket.

Formailag a terv kidolgozója az elfogadott tematikát, a környezeti vizsgálat ütemezését, a környezetvédelmi szervekkel kapcsolatos esetleges konzultációkra, a véleményezési eljárás menetére vonatkozó javaslatát megküldi a környezetvédelmi szerveknek, és egyidejüleg azokat nyilvánosságra is hozza. Arról, hogy ilyen döntés született volna - az esettanulmányban szereplö civil szervezetnek - nem volt tudomása, a tájékoztatást az önkormányzat mellőzte.

A településrendezési eszköz tervezetéhez hasonlóan a környezeti értékelést véleményezésre meg kell küldeni az érintett környezetvédelmi szervezeteknek, az eltérö véleményeket pedig - az érdekképviseleti és társadalmi szervezetek bevonásával megbeszélés keretében egyeztetni kell. A településrendezési eljárást szabályozó Étv. 9. § (3) és (4) bekezdésében rögzített közbenső véleményezési eljárásra figyelemmel, e vonatkozásban nincs szükség kiegészítő lépésre az önkormányzatok részéről.

Az SKV rendelet világos iránymutatást ad a tekintetben, hogy $a$ tervezettel együtt a környezeti értékelést is nyilvánosságra kell hozni, és a nyilvánosság számára véleményezési lehetőséget kell biztosítani. ${ }^{3}$ A környezeti értékelés nem jóváhagyásra kerülő, hanem alátámasztó szakági munkarész.

Az SKV rendeletnek a környezeti értékelésről szóló fejezetébe foglalt 8 . § (3) bekezdése alapján a környezeti értékelésnek és a terv, illetve program tervezetének a Kvt. 43. § (6) bekezdés $a$ ) pontja szerinti véleményezéséhez a kidolgozó megküldi a környezet védelméért felelős szervnek, és nyilvánosságra a következőket hozza:

a) a terv, illetve program célja,

b) a terv, illetve program környezeti értékelést is tartalmazó egyeztetési dokumentációja hol és mikor tekinthető meg,

c) milyen módon és időpontig lehet észrevételeket tenni,

3 SKV rendelet „7. § (5) A kidolgozó a környezeti értékelés (4) bekezdés szerint elkészitett tematikáját, ütemezését, valamint a környezet védelméért felelös szervekkel való esetleges további konzultációkra vonatkozó javaslatát és a nyilvánosság tájékoztatásának, észrevételei kérésének tervezett módját a környezet védelméért felelös érintett szerveknek megküldi, és nyilvánosságra is hozza." 
d) a terv, illetve program szempontjából releváns és rendelkezésre álló környezeti információk, valamint azok megismerhetősége.

A környezeti értékelés véleményezési eljárásának tehát meg kell elöznie a HÉSZ rendelet-tervezetének lakossági véleményezését. Ez az egyeztetés a tanulmányban górcső alá vett eljárásban azonban egyértelmüen a HÉSZ, tehát a kész rendelet-tervezet véleményezésére korlátozódott.

Az SKV rendelet 8 . $§(5)$ bekezdése a nyilvánosságra hozatallal összefüggésben úgy rendelkezik, hogy ha az érintett nyilvánosság csak egy településrészre korlátozódik, ott elégséges a helyben szokásos nyilvánosságra hozatal is, de ha a kidolgozónak van honlapja, a tájékoztatást azon is nyilvánosságra kell hozni.

A jogszabály kógens rendelkezése alapján a környezeti értékeléssel kapcsolatos információkat tehát nyilvánosságra kell hozni.

A tanulmányban szereplö önkormányzatnak volt hivatalos honlapja. Ezen a Társadalmi egyeztetésre bocsátott rendeletek között szerepeltek a HÉSZ rendelet-tervezetének a véleményezésére vonatkozó tájékoztatások, a rendelet tervezete, valamint a településszerkezeti terv és a szabályozási tervek, azonban nem szerepelt a környezeti értékelés, a környezeti értékelés jogszabály szerint közzétenni szükséges tematikája, ütemezése, a környezet védelméért felelős szervekkel való esetleges további konzultációkra vonatkozó javaslat, amint a nyilvánosság tájékoztatásának, észrevételei kérésének tervezett módja sem.

A helyi lakosság és a civil szervezetek számára a jogszabály külön eljárásban biztosít lehetőséget arra, hogy a település tervezett szabályozásának környezetre gyakorolt hatásait elemezzék, megvitassák, észrevételezzék. A környezeti értékeléssel összefüggő tájékoztatás hiánya, a nyilvánosság mellőzése a településtervezés várható környezeti hatásait illetően korlátozza a helyben élök magánszemélyek és civil szervezetek - mozgásterét, hogy hatást gyakorolhassanak a környezetüket, és ezen keresztül egészségüket hosszú távon befolyásoló települési tervekre, hogy tisztában lehessenek a jövőben várható környezeti hatásokkal. A környezeti vizsgálat jogszerü lefolytatásának kereteit éppen ezért külön jogszabály állapítja meg, és a törvény azt is kimondja, hogy 
környezeti értékelés nélkül a terv, illetve program nem terjeszthetö elö.

Mindezek alapján, figyelemmel arra, hogy jogszabály szerint a település egészére készülő rendezési terveknél a környezeti vizsgálat lefolytatása minden esetben kötelező, az egyesület véleményének benyújtásakor kérte a környezeti vizsgálat és a tervet alátámasztó dokumentumok megküldését.

Természetesen az egyesület - szem előtt tartva azt a célt, hogy a településtervezés egyeztetési eljárásból ne záródjon ki - határidőben juttatta el véleményét az önkormányzathoz. Ez a vélemény azonban nyilvánvalóan nem lehetett teljeskörü, mivel a környezeti értékelés és a kapcsolódó, tervet alátámasztó dokumentumok ehhez nem álltak rendelkezésükre. Az egyesület ezért elektronikus úton a környezeti értékelést, a kulturális örökségvédelmi hatástanulmányt, a biológiai aktivitásérték számítást, a területfelhasználási módosítások térképi ábrázolását és szöveges magyarázatát tartalmazó dokumentumokat kérte pótlólag megküldeni.

Az egyeztetés - bár az esettanulmány által felölelt időszakban több is volt - a kész HÉSZ rendelet-tervezet véleményezésére korlátozódott. A helyieket, civileket, a településen élőket ezzel kizárta az önkormányzat abból, hogy a településterv környezetre és a település hosszabb távú jövőjére gyakorolt hatásait elemezzék, közösen vitassák meg, illetve észrevételezzék az eljárásban, annak ellenére, hogy számukra törvény biztosítja ennek lehetőségét. Az ezekben a dokumentumokban rögzített adatok elengedhetetlenek ahhoz, hogy a helyben lakók, a civil szervezet is informálódjon, és közösen véleményt formáljanak.

A kulturális örökségvédelmi hatástanulmány ismerete a település további fejlesztését tekintve különösen azért fontos a helyiek számára, mert a tervezett HÉSZ-ben a korábbi régészeti területek nem szerepeltek, a térképi részen a történeti településrész nem került lehatárolásra, mindezzel együtt viszont a helyi építészeti örökség pusztult. A tervezés időszakában a civil társadalom rendelkezésére álló dokumentumok nem tükrözték azt, hogy ezeket az értékeket a jövőben miként kívánják védeni.

A biológiai aktivitásérték számítás ismerete a degradálódó természeti élőhelyek, illetve a drasztikusan csökkenő erdőborítottság miatt vált kiemelt jelentőségüvé. 
A HÉSZ tervezet ekkor a változások térképi ábrázolását és szöveges magyarázatát sem tartalmazta, ennek hiányában értelmezhetetlenné vált a terv helybéli környezetre hosszú távon kifejtett hatása.

(Bár az önkormányzat honlapján ebben az időben szerepelt egy környezeti értékelés, de ez a jogszabály szerint évente elkészítendő értékelés, és nem azonos a külön jogszabály által elkészítendő, településtervhez kapcsolódó, csak megfelelő végzettségü szakértő által elkészíthető környezeti értékeléssel.)

Az önkormányzat a 14 oldalas egyesületi vélemény benyújtását követően egy megbeszélést hívott össze. Az úgynevezett informatív megbeszélésen az önkormányzat településfejlesztési bizottságának elnöke, egy független szakértő, egy korábbi önkormányzati képviselő, az egyesület, és annak meghívására azoknak a szervezeteknek a képviselői voltak jelen, amelyekkel az elmúlt években - környezetvédelmi, természetvédelmi területen - az egyesület együttmüködött.

A civilek a kért dokumentumokat ezen a találkozón sem kapták meg, annak ellenére, hogy a megbeszélés jelentős része a környezeti értékelés körül folyt. Az egyesületnek nem maradt más lehetősége, 2015 márciusában az Nemzeti Adatvédelmi és Információs Hatóság elnökéhez fordult segítségért, hogy a településtervezési eljárás dokumentumait a helybéliek közössége megkaphassa és megismerhesse.

A legutolsó, az összehívó önkormányzat által informálisnak nevezett egyeztetésen az egyesület azt az álláspontot képviselte, hogy az önkormányzat folytassa le jogszerúen a környezeti értékelés eljárását, és azt követően indítsa el újra a településtervezési eljárást, a környezeti értékelés nyilvános véleményezési eljárása hiányában ugyanis jogszerüen nem fogadhatók el a településrendezési eszközök.

\section{Válasz a kérdésre: partnerségi-e az egyeztetés?}

Ha egy pillanatra visszatérünk a kiindulási ponthoz, ahhoz a célhoz, amely a helyi civil szervezetet életre hívta: a kavicsbánya vagy mezőgazdasági termelés és élhető környezet kérdéséhez, fel kell ismernünk azt, hogy a helyben lakó földmüves véleményében nem korlátozódik a saját belátható élettartamára, hanem számításba 
veszi a családja megélhetését biztosító tevékenységet folytató gyermekének kilátásait is. Ez azonban nehezen szorítható helyi jogszabály véleményezésének, vagy éppen a partnerségi egyeztetésnek a jogi korlátai közé. Mindazonáltal minden rendelkezésére álló eszközzel annak a célnak az elérése érdekében fog munkálkodni, hogy érdekét, a csoport, a képviselt közösség érdekét érvényre jutassa, még ha ehhez jelentős (jogi) kitérőket is kell tenni.

Végül egy utolsó kérdés vetődik fel. Ha az önkormányzat a partnerségi egyeztetést elöíró jogszabály alkalmazását mellőzi, bármilyen jogi eszközzel rábírható-e arra, hogy partnere legyen saját közösségének, partnerként tekintsen a helyi civil társadalomra? 


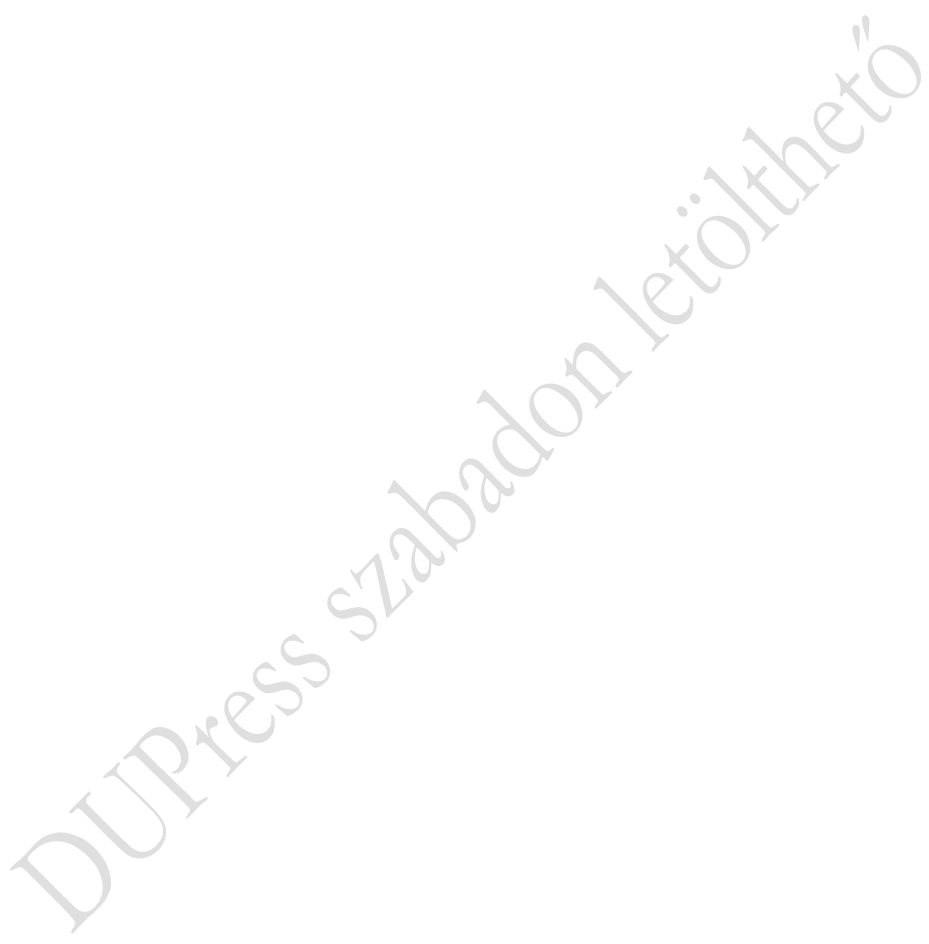

144 


\section{AZ IVÓVÍZHEZ VALÓ JOG BIZTOSÍTÁSA AZ OMBUDSMANI VIZSGÁLATOK TÜKRÉBEN}

Fórika László*

E tanulmány keretében az ivóvizhez való jog érvényesülésének esak igen szük és sajátos megközelítésére vállalkozhatom. Nem nyújtok teljes körü, a nemzetközi egyezményekre is részletesen kitérő elemzést. A jogérvényesülésnek is csak az egyik, speciális szempontú bemutatására törekszem: az ombudsmani vizsgálatok tapasztalatait összegzem.

E munkával kettős célom van. Fontos rámutatni arra, hogy Magyarországon az ivóvizhez való hozzáférés helyzete általában jónak, söt, kifejezetten jónak tekinthetö. Ugyanakkor a felmerülö problémák koncentráltan vannak jelen: a jogérvényesülési akadályoknak, nehézségeknek jól behatárolható területi és társadalmi-szociális jellege van, amelyeken belül a hazai cigányság messze túlreprezentált. Hangsúlyozni szeretném ezért azt is, hogy az ivóvizhez való jognak a hazai joggyakorlatban vannak (a kézenfekvö kapcsolódási pontokon túl) kifejezetten az egyenlö bánásmóddal összefüggö elemei is.

\section{Az ivóvízhez való jog, mint alapvető jog}

Bár egyre erősödik az az álláspont, hogy szükség van - a könnyebb érvényesíthetőség és a számonkérhetőség miatt - az ívóvízhez való jognak az önálló emberi jogként való elismerésére is, a vízhez és személyes higiéniához való hozzáférés jogát az emberi jogi tárgyú nemzetközi szerződések nem ismerik el önmagában: ezt a jogot a nemzetközi egyezmények más jogok érvényesülésének részeként, egyik elemeként kezelik.

\footnotetext{
* Dr. Fórika László az Alapvető Jogok Biztosa Hivatalának munkatársa, Budapest.
} 
Az önálló emberi jogi elismerés felé vezető legfontosabb lépcső, hogy az ENSZ Közgyülése 2010. július 28-án határozatában alapvető emberi jogként ismerte el a tiszta vízhez és a megfelelő szennyvízelhelyezéshez jutás jogát. „A Közgyülés (...) emberi jogként ismeri el a biztonságos és tiszta ivóvizhez és higiéniához való jogot." E határozat felszólítja a világ országait illetve a nemzetközi szervezeteket, hogy a szükséges erőforrások biztosításával és technológia átadásával segítsék elsősorban a fejlődő országokat azon cél megvalósításában, hogy mindenki számára biztosítható legyen a biztonságos, tiszta, elérhető és megfizethető ivóvíz, és a megfelelö szennyvízelhelyezés. Az ENSZ Emberi Jogi Tanácsa még ugyanebben az évben kiadta az „Emberi jogok és a biztonságos ivóvízhez és higiéniához való hozzájutás" címü határozatát, amiben megerősítette, hogy az ivóvízhez és higiéniához való jog a megfelelő életkörülményekhez való jogból származik, és elválaszthatatlanul kapcsolódik a legmagasabb szintü testi-lelki egészséghez, illetve az élethez és emberi méltósághoz való joghoz.

Mint látható, az ENSZ Közgyülése és az ENSZ Emberi Jogi Tanácsa az ivóvízhez és a higiéniához szükséges vízhez való jogot (bár nem teljesen konzekvensen) együtt kezeli.

Alkotmányunk, az Alaptörvény formálisan csak az ivóvízhez való hozzáférést nevesíti a Szabadság és felelösség cím alatt, úgy, hogy azt is egy a megfelelö életkörülményekhez való jognál szükebb joghoz kapcsolja - legalábbis közvetlenül. A $X X$. cikk ugyanis így szól:

„(1) Mindenkinek joga van a testi és lelki egészséghez.

(2) Az (1) bekezdés szerinti jog érvényesülését Magyarország genetikailag módositott élölényektől mentes mezögazdasággal, az egészséges élelmiszerekhez és az ivóvizhez való hozzáférés biztositásával, a munkavédelem és az egészségügyi ellátás megszervezésével, a sportolás és a rendszeres testedzés támogatásával, valamint a környezet védelmének biztositásával segíti elö."

A XX. cikk tehát önmagában és pro forma a higiéniához szükséges vízröl nem rendelkezik, az ivóvízhez való jog kapcsán pedig nem is használja a jog szót. Az ivóvízhez való hozzáférés biztosítására, vagyis az állami kötelességre helyezi a hangsúlyt, úgy, hogy azt a testi és lelki egészséghez való alapvető jog részének tekinti. Mindezek alapján az ivóvízhez való hozzáférés az egyéni 
szinten is érvényesíthető testi és lelki egészséghez való alapvető jog nevesített része, de közösségi jog, aminek biztosítása az állam feladata.

Ha ezt az intézményes jogvédelmi kötelezettséget az alapvető emberi jogokat szabályozó, Szabadság és felelösség cím egészében vizsgáljuk, látnunk kell, hogy az ivóvízhez való hozzáférés az Alaptörvényben nemcsak a testi-lelki egészséghez való joghoz kapcsolódik elválaszthatatlanul. Összefügg az egyén alapvető jogaként értelmezendő élethez és emberi méltósághoz (II. cikk), és a gyermekek megfelelö testi gondoskodáshoz való jogával (XVI. cikk) is, de kapcsolódik az egészséges környezethez (XXI. cikk) és a közszolgáltatásokhoz való hozzáférés (XXII. cikk, XXVI. cikk) közösségi jogaihoz is. Ebben a megközelítésben az ivóvízhez való hozzáférés egyúttal a személyes higiéniához való hozzáférést is jelenti, tartalmazza.

Az eddigi ombudsmanok az ivóvizhez és a személyes higiéniához szükséges vizhez való hozzáférést (az egészséghez, az emberi méltósághoz, az élethez, az egyenlőséghez, a gyermekek gondoskodáshoz való joga metszeteként, a „rendszerben”) az egyén szintjén is érvényesithetö alapvetö jogként értelmezték. Ekként rámutattak, hogy azt mindenki köteles tiszteletben tartani, az állam pedig elsőrendű kötelességeként köteles elismerni és (intézményes módon) védeni; törvényben szabályozni, és a jog érvényesüléshez szükséges jogi és más intézményes feltételeket biztosítani.

\section{Az ivóvízhez való hozzáférés}

Az ivóvízhez való hozzáférés kérdéskörének elsődlegesen négy eleme emelhetö ki: 1) a vízkészlet védelme, 2) a mennyiség, 3) a minőség, 4) az eljuttatás. A vízkészlet véges természeti erőforrás, amit horizontális védelemben kell részesíteni, úgy, hogy az állampolgárok a megfelelő minőségü és mennyiségü ivóvízhez hozzájussanak.

Az eljuttatásért az állam és a helyi önkormányzat felelős. Az eljuttatásnak két alapformája lehet: a víziközmü-szolgáltatás (ennek speciális esete a közkifolyók müködtetése) és az önkormányzati nem közműves ivóvízellátás.

Magyarországon szinte teljesen kiépült a vezetékes ivóvízhálózat. Különböző források szerint a lakosság $84 \%$-a jut hozzá vezetékes 
vízhez közvetlenül, 4\%-a közkifolyók használatával, s ellátási hiányosságok mindössze $2 \%$-ot érintenek. ${ }^{1}$

Az ivóvizhez hozzáférés problematikája alapvetöen háromféleképpen merülhet fel: 1) nincs elég viz, 2) az elérhetö víz nem jó minöségü 3) a vizdíj a szolgáltatást igénylö szempontjából, szociális helyzete alapján, túl magas. Felmérések, de az ombudsmani tapasztalat szerint is ezek a problémák gyakran átfedést is mutatnak.

A Kvassay Jenö terv szerint a szociálisan elmaradott térségek egybeesnek azokkal a területekkel, ahol nehezebb a vízhez való hozzáférés (például Nógrád, Somogy, Baranya megye dombvidéki, aprófalvas területei). Főként az észak- és dél-alföldi régióban a kutak vize geológiai eredetü szennyező komponenseket is tartalmaz, a kitermelt vizek tisztítást igényelnek. A Nemzeti Fejlesztés 2030 Országos Fejlesztési és Területfejlesztési Koncepcióról szóló 1/2014. (I. 3.) OGY határozat szerint az ország lakosságának hatoda nem jut minden szempontból (például bór, fluorid-, nitrát- illetve nitrit-, arzén-, ammónium-, vas-, mangán-tartalom) kifogástalan ivóvízhez.

A problémák koncentráltságát a következő (az említett OGY határozat által közzétett) térképek jól szemléltetik.

$\mathrm{Az}$ elmaradott településeken szignifikánsan alacsonyabb a vízfogyasztás.

\footnotetext{
${ }^{1}$ Kvassay Jenő Terv Nemzeti Vízstratégia (tervezet) Budapest, 2016. november 20., http://docplayer.hu/11781826-Kvassay-jeno-terv-nemzeti-vizstrategia-budapest-2015november-20.html (2017.03.03.).
} 

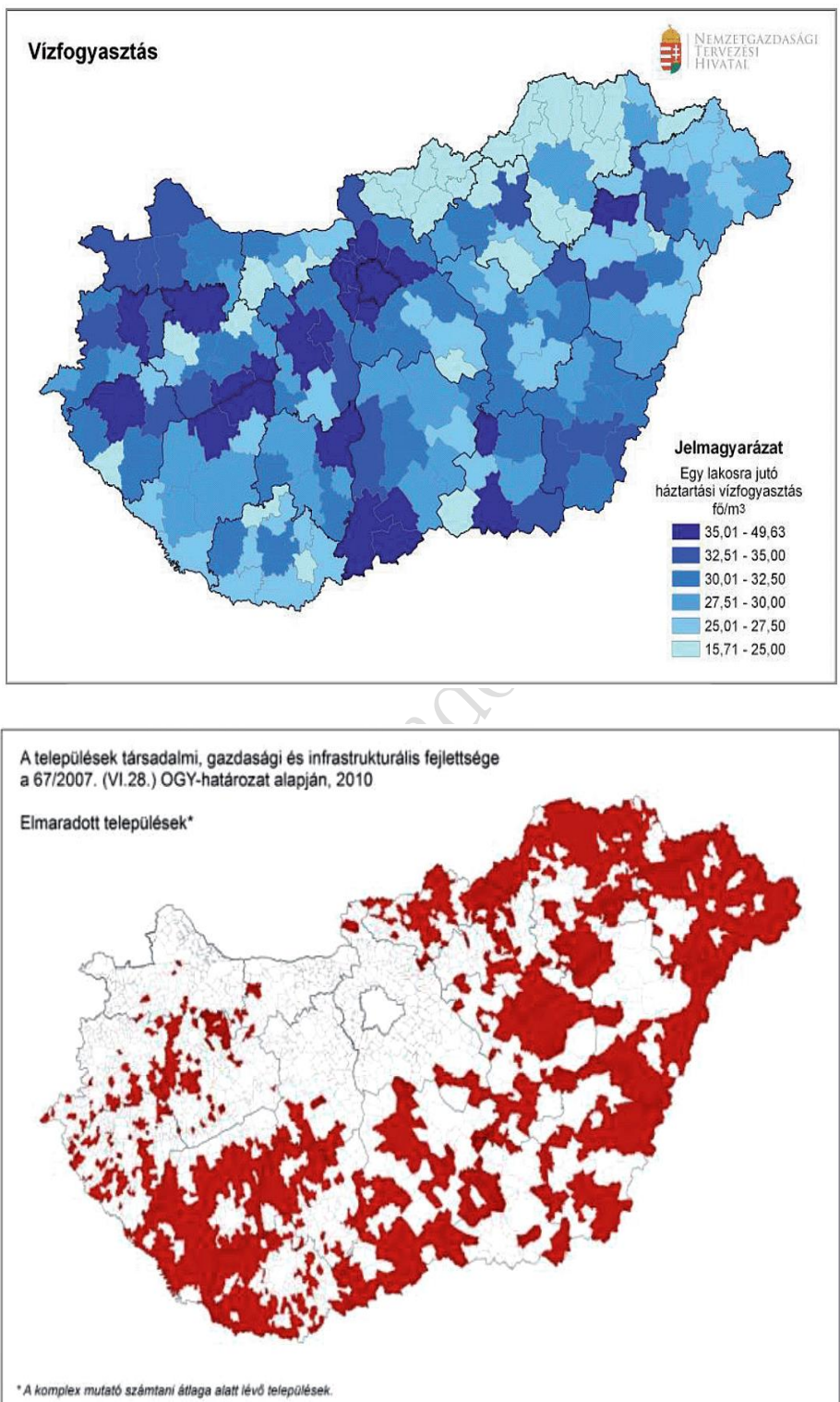

Elmaradott telepulések*

- A komplex mutató számtani átlaga alatt lévó telepulések. 
Erős a kapcsolat, nagy az átfedés a roma népesség területi elhelyezkedése és az elmaradott régiók között.

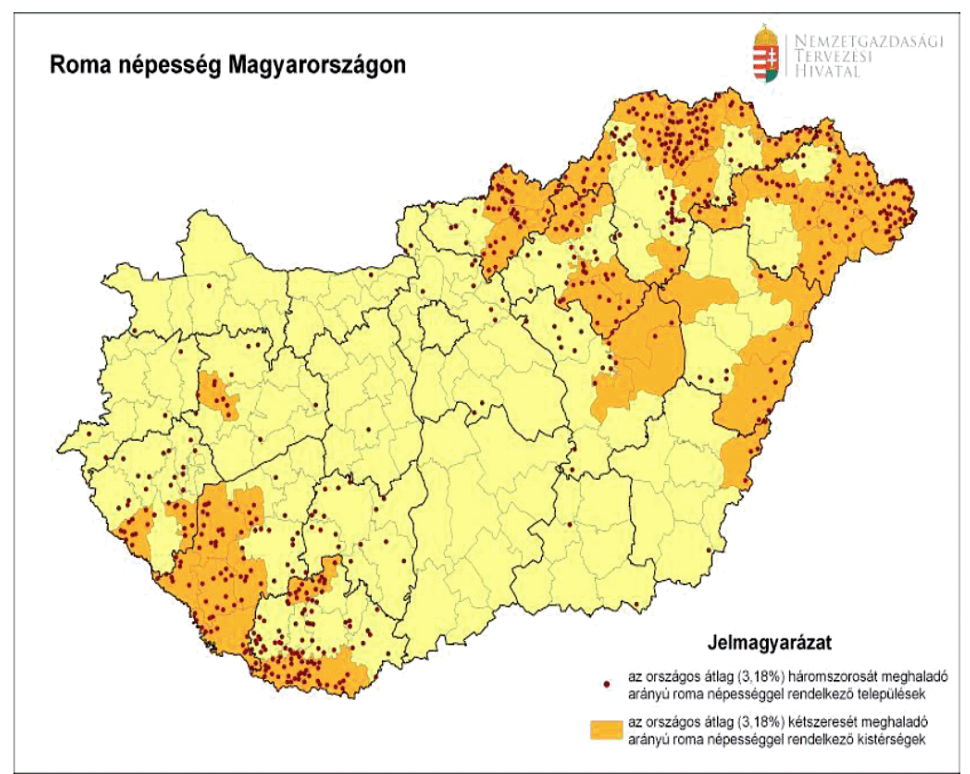

$\mathrm{Az}$ előző térképekkel összevetve jól látható, hogy a vízfogyasztásnak, a szegénységnek, a roma lakosságnak és az egészségnek is van térképre vetíthető összefüggése. 


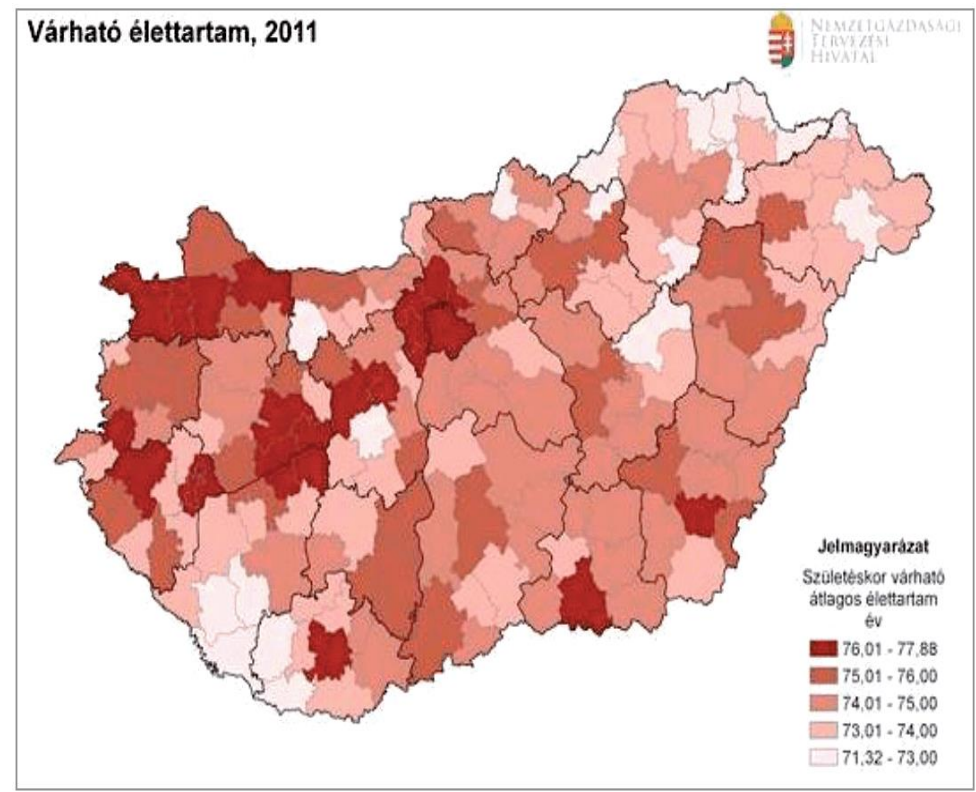

Összességében elmondható, hogy az ivóvíz nehezebben hozzáférhetö volta, az ivóví minöségi problémái, az ivóviz megfizethetösége különösen élesen vethetö fel a hazai cigányság esetében. A szegénység és az ivóvizhez való hozzáférés problémaköre együtt az életkilátások csökkenését is okozza, aminek szintén felülreprezentált alanya a cigányság.

\section{Az ivóvízzel kapcsolatos beadványok típusai}

Öt évre visszamenőleg tanulmányoztam az ombudsmani hivatal ivóvízzel kapcsolatos ügyeit. Ennek alapján négy alaptípus állapítható meg: víziközmü-szolgáltatással, közkifolyókkal kapcsolatos panaszügyek, hivatalból indított ügyek és jogszabályvéleményezések.

A víziközmü-szolgáltatás kapcsán felmerülö ügyek jellemzöen szociális jellegüek, amelyek alanyai a szegények, köztük részben a romák. Az ilyen panaszok tárgya leggyakrabban a fejlesztési 
hozzájárulás, és annak visszaigénylése, a rákötési költség, a vízdíjtartozás, a szolgáltatás megszüntetése.

A közkifolyók kapcsán megindított vizsgálatok az elérhetőséget sérelmezik, és gyakran diszkriminációra is hivatkoznak. Sérelmezik a közkifolyók alacsony számát, kedvezötlen területi elhelyezkedését, távolságát, az indokolatlanul csökkentett vízmennyiséget, a kútlezárásokat, és a kutak hiányát külterületen, üdülési övezetben, illetve a szegregátumokban. Ezekben az ügyekben a panaszosok szinte kizárólag romák.

A hivatalbóli ügyek száma csekély, ezen belül a nagyobb arányt a gyermeki jogokkal összefüggő ügyek teszik ki, diszkriminációval összefüggő ex officio ügy mindössze egy volt az utóbbi öt évben.

$\mathrm{Az}$ ombudsman a feladatkörét érintő jogszabály-tervezeteket köteles véleményezni, így viszonylag gyakran kap észrevételezésre vízhez való joghoz kapcsolódó elöterjesztéseket is. Ezek az ügyek azért fontosak, mert a biztos (a környezetjogért felelös helyettesével) megelőzheti a jogalkotás útján létrejövő visszásságokat.

\section{Az ózdi kútelzárás ügye, 2013}

Az ózdi kútelzárás emlékezetes esetét ${ }^{2}$ azért tartom fontosnak kiemelni, mert jól mutatja a környezethez való jog, ezen belül a vízhez való jog keresztülfekvő jellegét. Az ügynek (egyebek mellett) voltak vízgazdálkodással, az ívóvíz hozzáférhetővé tételével, az önkormányzati szabályozással, az önkormányzati gazdálkodással, a törvényességi felügyelettel, a népegészségügyi hatósági engedélyezési eljárással, az EU-s pénzek felhasználásával, az egyenlö bánásmód biztosításával kapcsolatos elemei is. $A z$ ügy bizonyítja, hogy a diszkrimináció a vizhez való jog biztositása körében is felmerülhet. Fontos ez az ügy azért is, mert a biztos és „zöld" helyettese az elkészült jelentést - ilyenként az elsők között közösen írta alá. (A nemzetiségi jogi helyettes a nemzetiségi jogi vonatkozások ellenére nem írta alá a jelentést, de csak azért, mert aktuálisan nem volt betöltve ez a tisztség.)

\footnotetext{
${ }^{2}$ Az alapvető jogok biztosa és a jövő nemzedékek érdekeinek védelmét ellátó biztoshelyettes Közös Jelentése az AJB-5527/2013 számú ügyben, http://www.ajbh.hu/documents/10180/111959/201305527.pdf (2017.03.03.).
} 
A helyi önkormányzat többhónapos elökészítéssel, júliustól korlátozta 62 közkifolyó vízhozamát, illetve 27-et elzárt Ózd szegregátumaiban, telepszerü lakókörnyezeteiben. Mindeközben a 2013-as év júliusa a harmadik legszárazabb július volt 1901 óta, és az ország legmelegebb területe éppen az északnyugati országrész volt. Ez ugyan nem volt elöre látható, de mivel az éves vízigény időszakos ingadozása jól modellezhető, a döntéshozó önkormányzat azt bizonyosan tudhatta (és nyilván tudta is) már a döntés-előkészítés szakaszában, hogy nyári időszakban akár 35\%-kal is megemelkedhet az átlagos vízfogyasztási szükséglet.

A döntést két okra alapozták: a takarékosságra és a rend igényére. Fontos kiemelni, hogy a polgármester az egyik sajtónyilatkozatában a rendre helyezte a hangsúlyt. Az intézkedés célja a takarékosabb vízfogyasztás elérése, a kifolyók elhelyezésének racionalizálása (a vonatkozó elöterjesztés szerint ezek helyenként egymástól 50-100 méter távolságra voltak), és a jogellenes használat (pl. autómosás, öntözés) visszaszorítása volt.

$\mathrm{Az}$ ombudsman és (a helyettese) megállapításait és következtetéseit rendkívül széleskörü adatgyüjtésre alapozta. Tájékoztatást kért az illetékes kormányhivataltól, a város polgármesterétől, elemezte valamennyi releváns előterjesztést, határozatot, az integrált városfejlesztési stratégiát, a helyi esélyegyenlőségi programot, a kapcsolódó jogszabályokat, de a hazai és a nemzetközi sajtó teljes spektrumát is.

A közös jelentés megállapította, hogy az önkormányzat megalapozatlanul hivatkozott takarékossági okokra, ugyanis a lezárt közkutakon a fogyasztás a helyi rendeletben meghatározott átalánymennyiség, míg a nyomáscsökkentett kutaknál a létfenntartási és közegészségügyi vízmennyiség alatt volt. A biztos és a helyettese rámutatott, hogy a korlátozó döntés csak látszólag vonatkozott valamennyi jogalanyra, zömmel romákat érintett. Mivel az intézkedés önkényes indokokon alapult, és a korlátozás nem volt elkerülhetetlen, illetve kollektív büntetési jellege is volt, a diszkriminációt és az emberi méltóság megsértését is meg lehetett állapítani. 


\section{5. Összegzés}

Az ivóvíz elérhetőségének problémái területileg súlypontozhatóak, miközben a szegénységnek is van regionalitása, és a cigányság területi koncentrálódása is szignifikáns. Ezek között nagy az átfedés.

Az ombudsmanhoz érkező, vízhez való joghoz kapcsolódó panaszok jellemzően szociális jellegüek (ezért zömmel hatáskörön kívül esnek), érintettjei pedig a szegények és különösen a szegény romák.

A vízhez való jog érvényesítése esetenként az egyenlő bánásmód kérdéskörével is összefügg.

\section{Kitekintés}

Számos kutatási adat szerint Magyarországon az átlagos vízfogyasztás naponta kb. 100 liter személyenként. Ebből a közvetlen fogyasztás (az ivás és a fözés) a legkisebb tétel, 3-4 liter. A mosogatás, a takarítás, a naponként többszöri kézmosás, a zuhanyozás, a fürdés, a mosás, a WC öblítése ennek a 3-4 liter/fö/napos tételnek külön-külön is a többszörösét teszik ki. Egy vezetékes vízzel nem rendelkező háztartás vízfogyasztása nyilvánvalóan lényegesen alacsonyabb 100 liter/fónél, de mivel a napi vízigényt alapvetöen a háztartási és a személyi higiéniai szükségletek kielégitése határozza meg, a vízfogyasztás minimális szint alá szoritása (még a köztudomás szerint is) egészségügyi és járványügyi kockázatot jelent.

Evidens, hogy a közkifolyóknak az egyes, vezetékes vízzel nem rendelkező háztartásoktól való távolsága, elérhetősége nem a közvetlen fogyasztásra, hanem a higiéniai szükségletek kielégítésére hat elsődlegesen. Ha tehát a közkifolyókra vonatkozó szabályozás a kötelező minimális távolságot megemeli, különösen, ha ezt a fogyasztók számától függetlenül teszi, akkor az az egyes közkifolyók leszerelési lehetöségét jelenti a helyi önkormányzatok, és a higiéniai szükségletek további visszaszorításának kényszerét a fogyasztók szempontjából.

A víziközmü-szolgáltatásról szóló 2011. évi CCIX. törvény a közegészségügyi követelmények teljesítéséhez szükséges ivóvízellátás „biztosítottságát” 2015. július 23-ig egységesen kezelte. 
Így fogalmazott: „,58. § (10) a közegészségügyi követelmények teljesitéséhez szükséges ivóvizellátás akkor biztositott, ha az

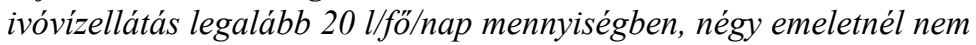
magasabb lakóépület esetén legfeljebb 150 m távolságon belüli, négy emeletnél magasabb lakóépületben pedig négy emeletnél nem nagyobb szintkülönbséggel járó vizvételezési lehetőséggel (közkifolyóról, tüzcsapról, szállitott vizböl) adott."

Ezt követően a jogalkotó a szabályozást egy kiegészítéssel differenciálta, amit aztán 2016. július 4-étől tovább pontosított. A jelenleg hatályos szabály így szól: „,58. § (10) A közegészségügyi követelmények teljesitéséhez szükséges ivóvizellátás akkor biztositott,

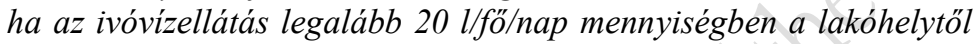
számítottan legfeljebb 150 méter, közterületen megteendö távolságon belül elérhetö. Négy emeletnél magasabb lifttel - vagy üzemképes lifttel - nem rendelkezö lakóépület esetében négy emeletnél nem nagyobb szintkülönbséggel kell a közegészségügyi követelmények teljesitéséhez szükséges ivóvizellátást biztositani.

(11) Közszolgáltatási szerződés hiányában közmüves ivóvizet a közkifolyókról vagy más vízvételi helyröl rendszeresen vételezö természetes személyek számára az ivóvízellátást legalább 20 liter/fö/nap mennyiségben, a lakóhelytöl számitottan legfeljebb 300 méter, közterületen megteendö távolságon belül szükséges biztositani."

A szabályozás változása egyértelmüen súlyos hátrányt jelent a közkifolyók közüzemi szerződéssel nem rendelkezö használói (azaz a legszegényebbek) számára. 


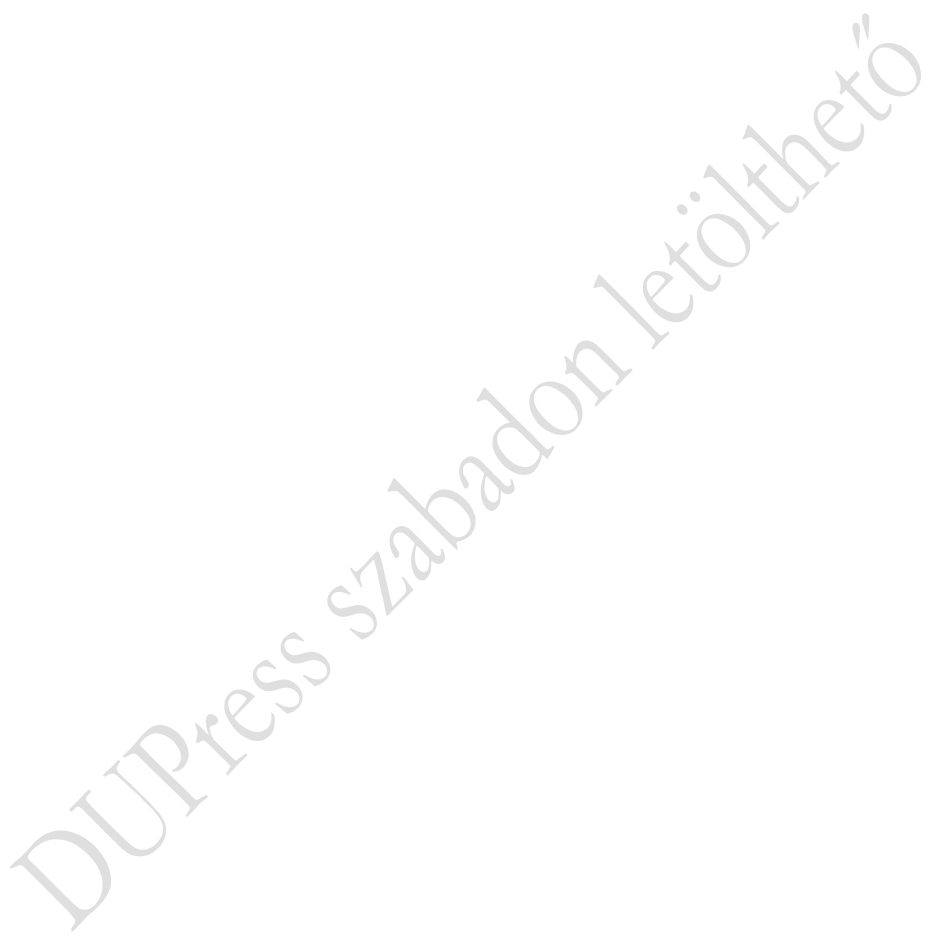




\section{FÜGGELÉK - A K115530 SZ. KUTATÁSI PROJEKT ONLINE KÉRDŐÍVE}

„Helyi önkormányzati szerepek és eszközök az ökológiai fenntarthatóság megvalósításában” (115530 sz. NKFIH pályázat, Debreceni Egyetem Állam-és Jogtudományi Kar), 2016.

A kérdőiv kitöltése önkéntes!

A Polgármesteri Hivatal környezeti ügyekért felelős vezetőjének, munkatársának!

Dr. Fodor László egyetemi tanár vagyok, a Debreceni Egyetem Állam- és Jogtudományi Kar Agrárjogi, Környezetjogi és Munkajogi Tanszékének a vezetője.A Nemzeti Kutatási, Fejlesztési és Innovációs Hivatal jóváhagyásával karunkon (K115530 nyilvántartási számon) létrehozott kutatócsoport képviseletében írok Önöknek.

11 kutató részvételével 2015 őszétől 2018 tavaszáig “Helyi önkormányzati szerepek és eszközök az ökológiai fenntarthatóság megvalósításában" címet viselő projektünk keretében azt vizsgáljuk, hogy vajon a hazai települési önkormányzatok milyen szerepet töltenek/tölthetnek be a tág értelemben vett környezetpolitikában, a környezeti jog alakításában és végrehajtásában.

A több különböző, ugyanakkor szervesen egymásra épülő módszerrel végzendő kutatásunk elképzelésünk szerint mintegy 300 önkormányzat kérdőíves megkeresésével, továbbá ezek egy részében fókuszcsoportos interjúk készítésével is együtt jár majd. A kutatás számos adatot, helyzetértékelést, hazai és külföldi cselekvési mintákat, továbbá intézkedési javaslatokat eredményez, amelyeket a helyi környezetvédelmi ügyek kapcsán maguk az önkormányzatok is hasznosíthatnak a továbbiakban. Ugyanakkor ezek feltárásához nélkülözhetetlen az önkormányzatok támogató együttmüködése. 
Épp ezért kérjük Önöket, hogy e kérdőív kitöltésével segítsék kutatásunkat. Az eredményekről természetesen tájékoztatjuk az önkormányzatokat.

A település neve:

A kérdőívet kitöltő beosztása:

\section{Jogszabályi környezet és jogértelmezés}

1. Vannak-e jogértelmezési problémáik a központi környezetvédelmi/környezeti jogszabályok alkalmazása során?

1 = igen, minden esetben $2=$ igen, egyes esetekben $3=$ még nem fordult elö

1.1. Mik a tipikus, előforduló problémák az alkalmazás során (többet is választhat)?

1 = a központi jogszabály túl általános

2 = a helyi kérdések (egy része) nem kezelhető a jogszabályok alapján

3 = a szankcionáláshoz nem álnak rendelkezésre eszközök (pl. szakember)

4 = helyi társadalmi/önkormányzati érdekek sérülhetnek

1.2. Sérült-e a központi előírások változásai miatt a közelmúltban valamilyen helyi/ önkormányzati érdek az Önök teleülésén (kerületében)?
$1=$ igen
$2=$ nem

1.2.1. Ha igen, kérjük mutassa be, mi volt az.

2. Kapnak-e, s ha igen kitől, segítséget, ha konkrét jogértelmezési kérdésük van valamely környezeti jogszabály kapcsán? 
$1=$ igen, kapnak $\quad 2=$ nem szoktak kérni

$3=$

nem kapnak, bár kérnének

2.1. Kitől kapnak segítséget (többet is választhat)?

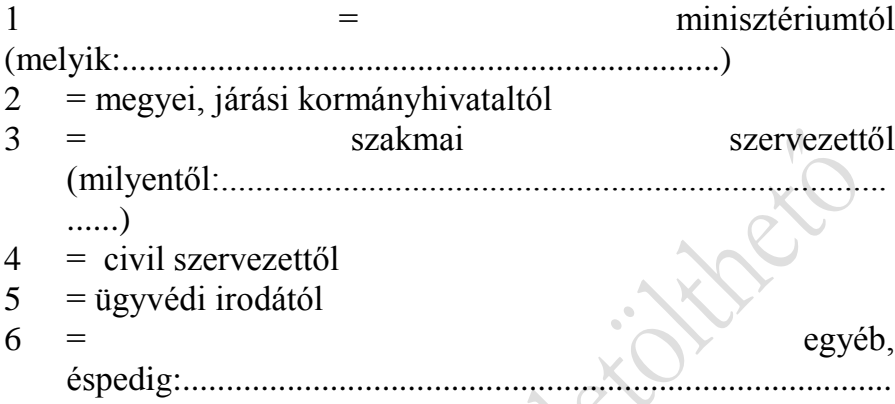

3. Kérjük, nevezze meg, milyen országos jogszabályi előírásokon módosítana annak érdekében, hogy a település a saját környezetpolitikáját hatékonyabban meg tudja valósítani?

4. Tekintetbe veszik-e településükön (kerületükben) a környezetvédelmi szabályozás és gyakorlat során a nemzetközi jog, illetőleg az Európa-jog valamely környezetjogi szabályozását, vagy a külföldi "legjobb gyakorlatokat"?

$1=$ igen $2=$ nem, mert a hazai szabályozás elegendő $3=$ nem, mert nincs erre szakmai kapacitás és személy
4.1. Ha
igen,
akkor
az
miben
nyilvánul meg: 
5. Hogyan alkalmazkodnak a változó jogszabályi környezethez? $1=$ a régi (helyi) jogszabályi szövegbe szerkesztik a változásokat

$2=$ teljesen új szöveget készítenek a helyi feltételek figyelembe vételével

$3=$ a törvény szövegét alkalmazzák minimális változtatással

4 = más önkormányzatok megoldásait veszik át

5 = igyekeznek a helyi sajátosságokat érvényesíteni

6. A környezeti kérdésekben hozott döntéseik előkészítése során milyen belső (polgármesteri hivatalon belüli) szervezeti egységekkel egyeztetnek? Kérjük, nevezze meg azokat:

6.1.A döntés előkészítések során milyen külső (települési, településen kívüli) szervezetekkel egyeztetnek? Kérjük, nevezze meg azokat:

7. Az alábbiak közül milyen stratégiákkal rendelkezik a település? Többet is választhat!

$1=$ környezetvédelmi program

$2=$ fenntartható fejlődési stratégia/Local Agenda 21 program

3=éghajlatváltozási stratégia

$4=$ energiastratégia 
7.1. A helyi szintü rendelet,- illetve stratégiaalkotás során végeztek-e környezeti vizsgálatot? Többet is választhat!

1 = igen,

$2=$ nem

7.2. Ha végeztek környezeti vizsgálatot, figyelembe vették-e az eredményét?

$$
1=\text { igen } \quad 2=\text { nem }
$$

7.2.1. Kérjük, mutassa be, hogyan vették figyelembe a környezeti vizsgálat eredményeit, illetve, hogy miért nem vették figyelembe.

8. Származott-e környezeti konfliktus az önkormányzat valamely saját döntéséből?

$$
1=\text { igen } 2=\text { nem }
$$

8.2. Ha igen, mi volt, mik voltak azok:

\subsection{Hogyan oldották fel a konfliktust?}

9. Ön szerint mi jellemző az önkormányzatokra környezetvédelmi szempontok alapján?

Kérjük, ítélje meg, hogy az egyes módok mennyire jellemzőek; $1=$ egyáltalán nem jellemző az önkormányzatokra, $10=$ minden önkormányzatra jellemző ( $0=$ nem tudja megítélni)

\begin{tabular}{|l|ccccccc|}
\hline proaktív, megelőző & 1 & 2 & 3 & 4 & 5 & 6 & 7 \\
& 8 & 9 & 10 & 0 & & & \\
\hline
\end{tabular}




\begin{tabular}{|c|c|c|c|c|c|c|c|}
\hline $\begin{array}{l}\text { a már kialakult } \\
\text { problémákat oldja meg }\end{array}$ & $\begin{array}{l}1 \\
8\end{array}$ & $\begin{array}{l}2 \\
9\end{array}$ & $\begin{array}{c}3 \\
10\end{array}$ & $\begin{array}{l}4 \\
0\end{array}$ & 5 & 6 & 7 \\
\hline $\begin{array}{l}\text { csak a jogszabályokban } \\
\text { foglaltakat hajtja végre }\end{array}$ & $\begin{array}{l}1 \\
8\end{array}$ & $\begin{array}{l}2 \\
9\end{array}$ & $\begin{array}{c}3 \\
10\end{array}$ & $\begin{array}{l}4 \\
0\end{array}$ & $\overline{5}$ & 6 & 7 \\
\hline
\end{tabular}

9.1.Saját önkormányzatukat leginkább hova sorolja a lehetséges stratégiák alapján? (kérjük, egy lehetőséget válasszon)
$1=$ proaktív
2 = a kialakult problémákat oldja meg
$3=$ jogszabályi feladatokat hatja végre
$4=a$
konkrét helyzettől függ, hogy melyik opció érvényesül

10. Ön szerint mi az ,ideális" döntéshozatali mechanizmus környezeti kérdésekben (rendeletalkotásban, stratégia készítésében), és mi a jellemző az önkormányzatokra? (1 = egyáltalán nem jellemező, $5=$ teljes mértékben jellemző, $0=$ nem tudja megítélni)

\begin{tabular}{|c|c|c|c|c|c|c|c|c|}
\hline & \multicolumn{4}{|c|}{ ideális } & \multicolumn{4}{|c|}{ tényleges } \\
\hline $\begin{array}{l}\text { csak az önkormányzat } \\
\text { bizottságai és a } \\
\text { képviselőtestület vesz } \\
\text { részt a döntésekben }\end{array}$ & $\begin{array}{ll}1 & \\
5 & 0\end{array}$ & & & 4 & $\begin{array}{l}1 \\
5\end{array}$ & $0^{2}$ & & 4 \\
\hline $\begin{array}{lr}\text { az önkormányzat } \\
\text { szakemberei ré részt } \\
\text { vesznek a döntések } \\
\text { előkészítésében }\end{array}$ & & & 3 & 4 & $\begin{array}{l}1 \\
5\end{array}$ & $0^{2}$ & & 4 \\
\hline $\begin{array}{l}\text { figyelembe veszik a } \\
\text { területi zöldhatóság } \\
\text { (környezetvédelmi és } \\
\text { természetvédelmi } \\
\text { főosztály) véleményét }\end{array}$ & $\begin{array}{ll}1 & \\
5 & 0\end{array}$ & & 3 & 4 & 5 & $0^{2}$ & & 4 \\
\hline $\begin{array}{l}\text { külső szakemberek részt } \\
\text { vesznek a döntések } \\
\text { elökészítésében }\end{array}$ & $\begin{array}{l}1 \\
5\end{array}$ & 2 & 3 & 4 & 5 & $0^{2}$ & & 4 \\
\hline tudományos & 1 & 2 & 3 & 4 & 1 & 2 & & 4 \\
\hline
\end{tabular}




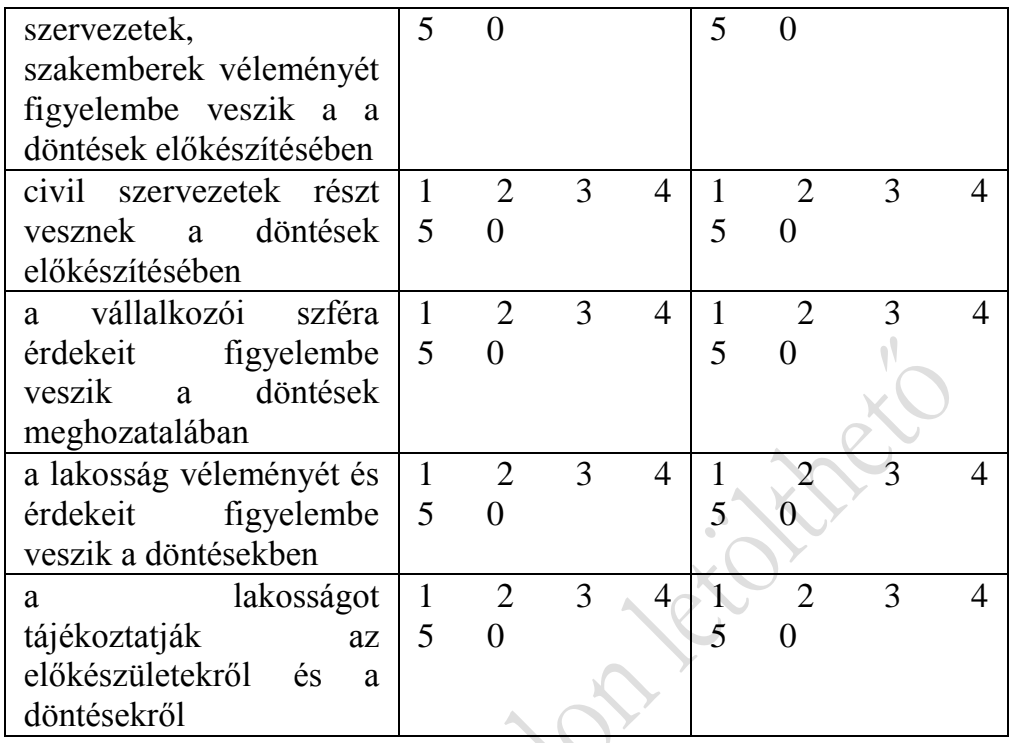

Külső és belső kapcsolatok, önkormányzati bizottságok, szakemberek

11. Hogyan látja el az önkormányzat a környezetvédelemmel kapcsolatos feladatait? (többet is választhat)

$1=$ van ilyen önálló szervezeti egysége

$2=$ nincs ilyen szervezeti egysége, a feladatokat szétosztják a megfelelő osztályok, személyek között

3 = csak egy személy felel ezekért a feladatokért

4 = a képviselők közötti tanácsnok látja el

11.1 (a 2. ponthoz) Ha a feladatokat szétosztják, kérjük, sorolják fel, milyen „reszortok” alakultak ki (pl. hulladékgazdálkodás). Kérjük, adják meg a reszortot ellátó személy (szakmai) végzettségét is (hasonlóan a 3. és a 4 . pont esetében is kérjük a végzettséget). 
12. Van-e az önkormányzatnak környezetvédelmi szakbizottsága?

$1=$ igen, van $\quad 2=$ nincs, de egy másik bizottság ellátja ezeket a feladatokat pl. a döntés elökészítésnél

3 = nincs, ad hoc látják el az ilyen feladatokat

13. Van-e együttműködés a hatósági feladatok ellátása terén a területi környezetvédelmi hatósággal?

$1=$ igen $\quad 2=$ nem

13.2. Ha van ilyen együttmüködés, mi annak a lényege, tartalma?

14. Van-e együttmúködés a nemzeti park igazgatósággal?

1 = igen $\quad 2=$ nem

14.1.Ha igen, mi annak a tartalma, lényege:

15. Vett-e már a település igénybe valamilyen szakismeretet igénylő környezetvédelmi szolgáltatást külső szervezettől? Többet is választhat!

15.1oktatást:

$1=$ igen $2=$ nem

15.2.tanácsadást:

$1=$ igen $2=$ nem

15.3.tanulmánykészítést: $1=$ igen $2=$ nem

15.4. tervezési szolgáltatást $\quad 1=$ igen $2=$ nem

15.5 kármentesítést

$1=$ igen $2=$ nem

15.6 pályázatírást

$1=$ igen $2=$ nem 
16. Javult vagy romlott az együttmúködésük a területi környezetvédelmi hatósággal annak a kormányhivatalba tagolása óta?

$1=$ semmit nem változott romlott

$$
2=\text { javult } 3=
$$

Környezeti problémák és jogviták, környezeti konfliktusok kezelése

17. Van-e, illetve korábban volt-e a településen jellemző (közismert és kevésbé ismert) környezeti probléma?

1 =igen $2=$ nem

17.1.Ha igen, mi volt az pontosan, és hogyan oldották meg?

18. Vannak/voltak-e környezeti konfliktusok, ökológiai nézeteltérések a szomszédos, közeli települések között?
$1=$ igen
$2=$ nem
$3=$ nem tud ilyenröl

18.1.Ha volt, mi volt az pontosan, és hogyan oldották meg?

19. Állt-e már jogvitában az önkormányzat környezeti problémával/beruházással kapcsolatban?

$$
1=\text { igen } \quad 2=\text { nem } \quad 3=\text { nem tud ilyenről }
$$


19.1.Ha volt, mi volt az pontosan?

20. Befolyásolja-e az önkormányzat fellépését a lakosság érzékenysége a környezeti problémák iránt? Ha igen, ez miben nyilvánul meg?

21. Van-e a településen olyan környezeti probléma, amely első sorban kisebbségi vagy más hátrányos helyzetü lakosokat érint?

1 = igen, mert ezek a lakosok olyan helyen élnek, ahol van környezetterhelés

$2=$ nincs ilyen

21.1.Mi pontosan ez a környezetterhelés?

\section{Beruházások, beszerzések és környezeti szempontok}

22. Volt-e jelentősebb környezetvédelmi beruházás 1990 óta? (Többet is választhat)

1 = igen, volt, döntően helyi forrásból

2 = igen, volt, döntően állami forrásból

3 = igen, volt, állami beruházás (ezért nem is az önkormányzat koordinálta) 
4 = igen, döntően uniós támogatásból

5 = igen, az üzleti, vállalkozói szektor beruházása volt, illetve finanszírozta

6 = igen és vegyes finanszírozású volt

$7=$ nem volt ilyen

22.1.Ha volt beruházás, illetve beruházások, mik voltak azok?

23. Az önkormányzat a beruházások és a beszerzések során figyel-e környezeti, klímavédelmi szempontokra? (Többet is választhat)

1 = igen, ez a helyi környezeti stratégiából is következik

2 = igen, a jogszabályok miatt

3 = igen, a támogatási források kritériumai miatt

4 = igen, a lakosság és a civilek véleménye miatt

5 = igen, a helyi politikai ellenzék véleménye miatt

$6=$ igen, a helyi média miatt

$7=$ nem

24. Tud-e az önkormányzat példát mutatni a környezet- illetve klímavédelem területén a lakosainak?

$$
1=\text { igen } 2=\text { nem } 3 \text { = ez nem várható el } 4=
$$

nem tudja megítélni

24.1.Ha igen, milyen területen és formában?

\section{Helyi eszközök és lehetőségek}

25. Elegendőnek tartja-e az önkormányzat rendelkezésére álló eszközöket a (környezeti) fenntarthatóság megvalósítására?
1 = igen
$2=$ nem 
25.1.Kérjük, válaszát indokolja!

26. Kérjük, rangsorolja az önkormányzat lehetőségeit a környezet védelmében! (a második oszlopba írja rangsort jelentő számot)

$1=$ a legkevésbé jelentős $\quad 7=$ a legjelentősebb

\begin{tabular}{|l|l|}
\hline rendeletalkotás & \\
\hline ellenőrzés & \\
\hline engedélyezés & \\
\hline szankcionálás & \\
\hline közszolgáltatás szervezése & \\
\hline tulajdonosi joggyakorlás & \\
\hline stratégiaalkotás & \\
\hline
\end{tabular}

27. Lenne-e bármilyen feladat, amit átadnának, pl. a kormányhivatalnak?

$$
1=\text { igen } 2=\text { nem }
$$

27.1.Kérjük, indokolja válaszát!

Köszönjük, hogy válaszolt kérdéseinkre! 